Programa Interunidades em Ensino de Ciências.

\title{
DOIS ARGUMENTOS PELO CONHECIMENTO SOBRE A CIÊNCIA NO ENSINO DE CIÊNCIAS: POR UMA CONTRAIDEOLOGIA DO CONFLITO E UM METACONHECIMENTO PODEROSO
}

\author{
André Batista Noronha
}

Orientador: Ivã Gurgel

\begin{abstract}
Versão corrigida da tese de doutoramento submetida à banca como requisito para a obtenção do título de Doutor em Ensino de Ciências, na área de concentração em Ensino de Física. Versão original disponível na Biblioteca Digital de Teses e Dissertações da USP (BDTD).
\end{abstract}

São Paulo

2018 


\section{FICHA CATALOGRÁFICA \\ Preparada pelo Serviço de Biblioteca e Informação \\ do Instituto de Física da Universidade de São Paulo}

Noronha, André Batista

Dois argumentos pelo conhecimento sobre a ciência no ensino de ciências: por uma contraideologia do conflito e um metaconhecimento poderoso São Paulo, 2018.

Tese (Doutorado) - Universidade de São Paulo. Faculdade de Educação, Instituto de Física, Instituto de Química e Instituto de Biociências.

Orientador: Prof. Dr. Ivã Gurgel

Área de Concentração: Ensino de Física.

Unitermos: 1. Física - Estudo e ensino; 2. Educação; 3. Currículos e programas; 4. História da ciência; 5. Filosofia da ciência. 
O presente trabalho foi realizado com apoio da Coordenação de Aperfeiçoamento de Pessoal de Nível Superior - Brasil (CAPES) - Código de Financiamento 001.

This study was financed in part by the Coordenação de Aperfeiçoamento de Pessoal de Nível Superior - Brasil (CAPES) - Finance Code 001. 
Dedico a Suelen, e ao seu aveludado tenro. 
Quando jovem, se é só, apesar das múltiplas experiências. Pretende-se, nessa época, conformar a realidade com as mãos, se servir dela, pois há a fé de que, ganhando o mundo, se conseguirá ganhar o resto: a si mesmo. Acontece, entretanto, que se nasce para o encontro com o outro, e não ao seu domínio. Encontrá-lo é perdê-lo, é contemplá-lo na sua libérrima existência, é respeitá-lo e amá-lo na sua total e gratuita inutilidade. $\mathrm{O}$ começo da sabedoria consiste em perceber que se tem - e sempre se terá - as mãos vazias, na medida em que se tenha ganhado ou se pretenda ganhar o mundo. Neste momento, a solidão atravessa como um dardo. É meio-dia, e a face do outro se oferece como um enigma. Felicidade está na compreensão - em plena luz - de estar em plena treva, pobreza e vulnerabilidade. Este é o preço do encontro, do possível encontro com o outro. A construção de tal possibilidade passa a ser, desde então, o trabalho de se merecer a si mesmo.

Releitura de uma carta de Hélio Pelegrino a Fernando Sabino, prefácio da obra literária do autor mineiro de título O Encontro Marcado 


\section{Agradecimentos}

Devo fortemente a realização e conclusão deste trabalho ao apoio de meus familiares, amigos, professores e colegas do IFUSP, PIEC e IFSP ao longo dos últimos anos.

Agradeço a Ivã Gurgel pela seriedade, sinceridade e amizade durante toda sua orientação, desde a monografia de graduação, passando pelo mestrado, até o trabalho de doutorado.

A meus pais, avós e irmãs, obrigado pelo carinho e alegria.

A Suelen, agradeço pelo amor, paciência e companheirismo.

Sou grato ao apoio financeiro da CAPES ao projeto de pesquisa que culminou neste trabalho, entre os anos de 2014 e 2016. 


\title{
DOIS ARGUMENTOS PELO CONHECIMENTO SOBRE A CIÊNCIA NO ENSINO DE CIÊNCIAS: POR UMA CONTRAIDEOLOGIA DO CONFLITO E UM METACONHECIMENTO PODEROSO
}

\begin{abstract}
RESUMO
Apresentamos e discutimos neste trabalho dois argumentos, provindos de obras de dois dos principais teóricos de currículo, Michael Apple e Michael Young, em defesa do conhecimento sobre a ciência no ensino de ciências. Depois de um resgate histórico acerca do reconhecimento da importância da história e filosofia da ciência no ensino de ciências, retomamos as críticas de natureza filosófica à chamada visão consensual da natureza da ciência. Insistimos que a distância entre o debate sobre a natureza da ciência no ensino de ciências e suas críticas mantém-se longe de debates de natureza social, política e curricular, e apontamos para a necessidade de um papel político para a história e filosofia da ciência na educação científica. Afirmamos que isto significa terem um papel na resistência e combate a processos mais amplos ao ensino de ciências, como o processo de mercantilização da educação e da ciência e às ondas de valorização e desvalorização ideológica da ciência. Primeiro, com base em apontamentos da teoria crítica de currículo e em obras seminais de Apple e seu conceito de conflito, advogamos que a abordagem tipotenets presente na visão consensual tende, por sua forma, a ser convidativa a políticas de avaliações padronizadas, guiadas pelas ideologias neoliberal e cientificista-positivista, coadjuvantes a políticas educacionais mercantilizantes. Argumentamos, pois, que a história da ciência e o conceito de conflito devem ser entendidos como uma contraideologia do conflito às ideologias neoliberal e cientificistapositivista, emergindo seus papeis políticos de resistência aos processos de mercantilização da educação. Segundo, apoiados em obras recentes de Young e seu conceito de conhecimento poderoso, defendemos que o conteúdo da visão consensual flerta demasiadamente com visões subjetivistas, ressonantes a defesas relativistas epistêmicas pós-modernas. Assim, argumentamos que a filosofia da ciência, balizada por uma visão realista estrutural social, deve ser entendida como um metaconhecimento poderoso, proposição conceitual baseada naquela de Young, contra o relativismo epistêmico e políticas curriculares localistas que excluem a ciência. A natureza política deste argumento evidencia-se no fato de que tal exclusão viola princípios de equidade e de justiça social, traduzidos no apelo de garantia mínima acesso educacional irrestrito, amplo e efetivo a conhecimentos poderosos. Por fim, discutimos tensões entre os argumentos propostos, ponderações nas abordagens consideradas, e apontamos para desenvolvimentos futuros.
\end{abstract}

Palavras-chave: ensino de ciências, teoria de currículo, natureza da ciência, história da ciência; filosofia da ciência. 


\title{
TWO ARGUMENTS IN DEFENSE OF THE KNOWLEDGE ABOUT THE SCIENCE IN SCIENCE TEACHING: FOR A CONTRAIDEOLOGY OF CONFLICT AND A POWERFUL METAKNOWLEDGE
}

\begin{abstract}
We present and discuss in this thesis two arguments, based in the works of two leading curriculum theorists, Michael Apple and Michael Young, in defense of knowledge about science in science teaching. After a historical rescue on the recognition of the importance of the history and philosophy of science in science education, we discuss briefly the philosophical criticism over the so-called consensus view of nature of science. We argue that the distance between the debate on the nature of science in science teaching and its mains critics remains far from arguments of social, political and curricular nature, then we stress the need for a explicit political role for the history and philosophy of science in science education. This means take into account broader processes in education, such as the process of commodification of education and science and the waves of ideological valuation and devaluation of science. First, based on critical curriculum theory and in Apple's seminal works and his concept of conflict, we advocate that the tenetstype approach present in the consensus view, by its form, tends to be inviting to standard tests, high-stakes testing, as well to the neoliberal and scientistic-positivist ideologies, inherent in commodification policies. We argue, therefore, that the history of science and the concept of conflict must be understood as a counterideology of conflict against neoliberal and scientistic-positivist ideologies, and their political roles emerge as a resistance to the commodification processes of education. Second, based on Young's recent works and his concept of powerful knowledge, we argue that the content of the consensus view of nature of science is sympathetic to subjectivist visions, resonating with the postmodern epistemic relativism. Thus, our argument is that philosophy of science, guided by a realistic structural social view, should be understood as a powerful metaknowledge, a conceptual proposition based on Young's, against epistemic relativism and localist curricular policies that exclude science. The political nature of our argument is evidenced by the fact that such exclusion violates principles of equity and social justice, translated into the call for minimum guarantee of unrestricted, broad and effective educational access to powerful knowledges. Finally, we discuss tensions between the proposed arguments, as well limitations in our approaches, and point to future developments.
\end{abstract}

Keywords: science teaching; curriculum theory; nature of science; history of science; philosophy of science. 


\section{Sumário}

APRESENTAÇÃO

1 ENSINO DE CIÊNCIAS E CONHECIMENTO SOBRE A CIÊNCIA .23

1.1 Brevíssimo resgate sobre o consenso acerca da importância da história e filosofia da

ciência e natureza da ciência no ensino de ciências

A falta de consenso sobre o conteúdo da natureza da ciência

1.3 miséria da natureza da ciência

\section{CONHECIMENTO SOBRE A CIÊNCIA COMO UMA}

CONTRAIDEOLOGIA PELO CONFLITO

2.1 Capitalismo tardio, reformas educacionais e mercantilização da educação 51

2.2 Avaliações padronizadas e a visão consensual da natureza da ciência ............................... 66

Ideologia e cientificismo - ou, a ciência abduzida pelo capital .............................................8 80

Primeiro argumento: conhecimento sobre a ciência como contraideologia pelo conflito - ou, um papel político para a história da ciência no ensino de ciências 93

\section{CONHECIMENTO SOBRE A CIÊNCIA COMO UM} METACONHECIMENTO PODEROSO.

3.1 Relativismo epistêmico pós-moderno e a desvalorização ideológica da ciência

3.2 Localismo epistêmico-curricular

3.3 Conhecimento poderoso e justiça social - ou, sobre a importância de ir além

Segundo argumento: conhecimento sobre a ciência como um metaconhecimento poderoso - ou, um papel político para a filosofia da ciência no ensino de ciências

\section{TENSÕES INEVITÁVEIS, PONDERAÇÕES E CONSIDERAÇÕES}

FINAIS

4.1 Da sincera incompletude desta tese. 


\section{Índice de figuras e tabelas}

Figura 1: Representação imagética de uma abordagem essencialista de NdC.. ...........32

Figura 2: Representação imagética de uma abordagem semelhanças de família do tipo politética da $\mathrm{NdC}$. 33

Figura 3: Representação imagética da abordagem semelhanças de família do tipo politética da NdC. 36

Figura 4: A 'roda’ da abordagem semelhanças de família da NdC. 38

Tabela 1: Abordagem da Natureza da Ciência por temas e questões. 37 


\section{Apresentação}

Este documento é fruto de pouco mais de quatro anos de trabalho, realizado no Programa Interunidades em Ensino de Ciências da Universidade de São Paulo, entre os anos de 2014 e 2018. Seus contornos podem ser localizados dentro das áreas de pesquisa em ensino de ciências - em especial nas temáticas de história e filosofia da ciência e natureza da ciência - e de teorias de currículo. Este documento representa também o fim de um decênio do proponente dentro da Universidade de São Paulo, desde o ingresso no curso de graduação em licenciatura em física até a defesa de doutoramento.

Diferentemente da dissertação de mestrado que precedeu esta tese - limitada praticamente à temática de história e filosofia da ciência no ensino de ciências -, propõese neste trabalho uma incursão na bastante complexa área de teorias de currículo, tradicionalmente mais articulada por profissionais da área de educação e pedagogia. Algumas razões desta escolha merecem ser explicitadas. No primeiro semestre de 2014, o proponente teve a oportunidade de cursar a disciplina de pós-graduação Currículo $e$ Ensino de Ciências I, ministrada pelos professores doutores Ivã Gurgel e Maria Regina Dubeux Kawamura do Instituto de Física da Universidade de São Paulo. Lá, houve o contato mais formal com obras seminais do teórico de currículo estadunidense Michael Apple. Posteriormente, em 2015, o proponente, enquanto professor substituto do Instituto Federal de Educação, Ciência e Tecnologia, câmpus São Paulo, teve a chance de participar de grupos de reformulação de cursos técnicos-integrados. Pouquíssimo tempo depois, já como professor titular na mesma instituição, participou do processo de reformulação do currículo do curso de licenciatura em física do câmpus. Em ambos os casos, tratou-se de uma vivência direta com alguns conflitos sobre as reformas e políticas curriculares, envolvendo interesses ortogonais, influências políticas internas e externas, entraves burocráticos e disputas sobre os conhecimentos a serem legitimados. Em um olhar autorretrospectivo, deixa de se causar surpresa que a pesquisa inicial de doutorado até então orbitando quase que exclusivamente a área de história e filosofia da ciência -, migrou forte e decididamente para a área de teorias de currículo.

Em relativamente pouco tempo, houve um esforço concentrado à apropriação de parte do hall de principais trabalhos, artigos e ‘cânones’ da área de teorias de currículo. 
Considerando os trabalhos anteriores do proponente, foi uma atividade enriquecedora e prazerosa conhecer e aprofundar-se tanto nos clássicos como nas obras contemporâneas de Apple e também do sociólogo da educação britânico Michael Young. A leitura apaixonada destes autores é, até mesmo, reconhecível nos estilos de escrita adotados pelo neste documento, e no tom naturalmente denunciativo e crítico que o tema suscita bastante diferente, por sinal, do discurso em geral 'sereno' de trabalhos em história e filosofia da ciência no ensino de ciências. Apesar disto tudo, acreditamos não ser justo afirmar que este trabalho é 'um trabalho de teorias de currículo' - e, também, não parece ser possível dizer que é um trabalho completamente autêntico como determinadas obras de grande contribuição no tema de natureza da ciência e ensino de ciências. Tampouco soa preciso afirmar-se que ele contém uma 'mistura' destes temas. Essa dificuldade em delimita-lo pode refletir nas eventuais dificuldades em leitores (especializados nas temáticas ou não) em 'se habituar' ao longo das seções e capítulos. A natureza estrutural e complexa das questões e problemáticas tratadas - aliadas à apropriação apressada do proponente sobre os referenciais teóricos - impediram uma redação de tom mais ‘linear’ e sequencial, por vezes mais agradáveis à leitura.

Em um nível mais panorâmico, objetivo deste trabalho é o de aproximar as áreas de história e filosofia da ciência e teorias de currículo de forma a se encontrar 'saídas' para dois problemas mais gerais identificados na educação: os processos de mercantilização da educação (e também da ciência), amparados por políticas educacionais e ideologias neoliberais e cientificistas-positivistas, e; a existência dos fenômenos de valorização e desvalorização ideológica da ciência, este último vinculado a defesa relativistas epistêmicas, e sua influência sobre políticas curriculares localistas. A rigor, ambos estes problemas podem ser reunidos em um único: a manutenção (e, por vezes, a intensificação) das desigualdades sociais e o papel da educação nisso. Este, por sinal, é um dos motes centrais das teorias críticas e pós-críticas de currículo, desde o fortalecimento e reconhecimento destas a partir do fim da década de 1960. O fato infeliz de que, em geral, discussões acadêmicas na área de história e filosofia da ciência no ensino de ciências raramente mergulham nestas questões, reflete, ao nosso ver, a pertinência do objetivo deste trabalho. A despeito de toda contribuição já oferecida por pesquisadores daquela, é talvez chegada a hora (ou, já vem tarde) de entrar efetivamente (e de forma intensa) em lutas maiores, envolvendo não só aspectos de ensino e aprendizagem, mas também questões sociais extremamente urgentes e importantes, que não podem continuar despercebidas ou negligenciadas. 
Visando, assim, alcançar tal objetivo, construímos, apresentamos e discutimos dois argumentos teóricos, baseados em contribuições de Apple e Young. Resumidamente: (i) primeiro, com base em apontamentos da teoria crítica de currículo e no conceito de conflito trabalhado por Apple, advogamos que a abordagem tipo tenets presente na chamada visão consensual da natureza da ciência tende, por sua forma, a ser convidativa a políticas de avaliações padronizadas, guiadas pelas ideologias neoliberal e cientificistapositivista, coadjuvantes apolíticas educacionais mercantilizantes. Argumentamos, pois, que a história da ciência e o conceito de conflito devem ser entendidos como uma contraideologia do conflito às ideologias neoliberal e cientificista-positivista, emergindo seus papeis políticos de resistência aos processos de mercantilização da educação; (ii) em segundo, apoiados em obras recentes de Young e seu conceito de conhecimento poderoso, defendemos que o conteúdo da visão consensual flerta demasiadamente com visões subjetivistas, ressonantes a defesas relativistas epistêmicas pós-modernas - argumentamos que a filosofia da ciência, balizada por uma visão realista estrutural social, deve ser entendida como um metaconhecimento poderoso (proposição conceitual baseada naquela de Young), contra o relativismo epistêmico e políticas curriculares localistas que excluem a ciência. A natureza política deste argumento evidencia-se no fato de que tal exclusão viola princípios de equidade e de justiça social, traduzidos no apelo de garantia mínima de acesso educacional irrestrito, amplo e efetivo a conhecimentos poderosos.

A seguir, apresentamos resumos dos capítulos que se seguem e suas seções.

No capítulo introdutório, Ensino de ciências e conhecimento sobre a ciência, localizamos este trabalho dentro de uma tradição bastante antiga e ativa no ensino de ciências - o da história e filosofia da ciência no ensino de ciências. Em sua primeira seção, Brevíssimo resgate sobre o consenso acerca da importância da natureza da ciência no ensino de ciências, apresentamos desdobramentos recentes sobre o debate acerca das conceitualizações da natureza da ciência no ensino de ciências, comentando em particular o importante episódio de construção da visão consensual da natureza da ciência. Na seção seguinte, A falta de consenso sobre o conteúdo da natureza da ciência, discutimos como justamente essa visão consensual, apesar de uma conquista importante na área, tem sido duramente criticada nos últimos anos - especialmente do ponto de vista filosófico -, sofrendo inclusive a concorrência de propostas alternativas. Encerramos o capítulo com a seção de título A miséria da natureza da ciência, apontando para o fato de que as discussões excessivamente filosóficas e endêmicas no tema de natureza da ciência e ensino de ciências podem levar ao negligenciamento de questões urgentes associadas de 
forma mais geral à educação, e argumentando que a história e filosofia da ciência precisam também ter um papel político no ensino de ciências. Isto, apontamos, pode ser alcançado por meio de uma aproximação com a área de teorias de currículo.

O segundo capítulo desta tese, Conhecimento sobre a ciência como uma contraideologia pelo conflito, contém o primeiro argumento desta tese, fortemente inspirado na obra de Apple. Iniciamos com a seção Capitalismo tardio, reformas educacionais e mercantilização da educação, contextualizando minimamente o problema da mercantilização da educação e como isso está associado a reformas educacionais recentes - a título de exemplo, a reforma do ensino médio via medida provisória no Brasil em 2016, e, em parte, a versão proposta para ensino médio da BNCC publicizada em 2018. Em seguida, em Avaliações padronizadas e a visão consensual da natureza da ciência, debatemos sobre um dos principais mecanismos de controle (curricular e social) levado a cabo por políticas educacionais neoliberais, e como a visão consensual da natureza da ciência na forma de tenets é perigosamente suscetível a eles particularmente, por enquanto, no contexto de reformas curriculares recentes estadunidenses. A natureza ideológica da visão positivista-cientificista é um dos pontos centrais da seção Ideologia e cientificismo - ou, a ciência abduzida pelo capital. Nela, procuramos argumentar como as problemáticas apontadas nas seções precedentes (mercantilização da educação e ciência, avaliações padronizadas e políticas educacionais neoliberais, ideologias meritocrática-punitivas, entre outras) associam-se à ideologia cientificista-positivista - duramente criticada há anos, dentro e fora da pesquisa educacional. Concluímos este capítulo apresentando o primeiro argumento central da tese.

No terceiro capítulo, de título Conhecimento sobre a ciência como um metaconhecimento poderoso, contextualizamos a recente 'virada' na obra de Young, pioneiro na chamada nova sociologia da educação e, inicialmente, simpático ao neomarxismo como Apple. A primeira seção deste capítulo, Relativismo epistêmico pósmoderno e a desvalorização ideológica da ciência, nos propomos à difícil tarefa de identificar e descrever o relativismo epistêmico pós-moderno, e como se dá seu ataque de desvalorização ideológica à ciência. Depois, em Localismo epistêmico-curricular, procuramos exemplificar como o relativismo epistêmico pode influenciar políticas curriculares e teorias de ensino-aprendizagem - damos exemplos rápidos sobre formas radicais de construtivismo e multiculturalismo - e levar à desvalorização da ciência também nos currículos. Na terceira seção do capítulo, intitulada Conhecimento poderoso e justiça social - ou, sobre a importância de ir além, esclarecemos melhor o conceito 
central na nova fase de Young - conhecimento poderoso -, assim como da sua proposição teórica chamada realismo social, e discutimos como o autor defende que a desvalorização dos conhecimentos poderosos (como a ciência) nos currículos é uma medida com efeitos socialmente injustos, que violam princípios de equidade e que contribuem apenas para manter ou piorar as desigualdades sociais e educacionais. Por fim, encerramos o terceiro capítulo apresentado o segundo argumento central deste trabalho, propondo, antes, um ensaio teórico sobre o realismo social, sugerindo a adoção de uma postura realista social estrutural.

Finalmente, no capítulo de conclusão, Tensões inevitáveis, ponderações $e$ considerações finais, apresentamos algumas tensões entre as posturas de Apple e Young - assim como os argumentos apresentados. Em Da sincera incompletude desta tese, trazemos uma retrospectiva mais pessoal sobre a tese, e vislumbramos possíveis desdobramentos futuros dos objetos de pesquisa.

Todas as traduções de obras estrangeiras em citações são de nossa responsabilidade. Algumas siglas são utilizadas com muita frequência neste trabalho - por isso, entendemos ser útil aqui uma compilação destas:

$\begin{array}{lll}\text { BNCC = Base Nacional Comum } & \text { NCLB = No Children Left Behind } & \text { International Student Assessment } \\ \text { Curricular } & \text { NdC = Natureza da Ciência } & \text { RS = Realismo Social } \\ \text { EC = Ensino de Ciências } & \text { NSE = Nova Sociologia da } & \text { RTTT = Race To The Top } \\ \text { EsP = Escola sem Partido } & \text { Educação } & \text { RSE = Realismo Social } \\ \text { FC = Filosofia da Ciência } & \text { NSES = Nacional Science } & \text { Estrutural } \\ \text { HC = História da Ciência } & \text { Education Standards } & \text { VCNdC = Visão Consensual da } \\ \text { HFC = História e Filosofia da } & \text { OE = Objetivismo Estrutural } & \text { Natureza da Ciência } \\ \text { Ciência } & \text { PISA = Programme for } & \end{array}$




\title{
1 Ensino de ciências e conhecimento sobre a ciência
}

\subsection{Brevíssimo resgate sobre o consenso acerca da importância da história e filosofia da ciência e natureza da ciência no ensino de ciências}

\begin{abstract}
A gente pode substituir o ensino de física atual por História [da Ciência] e nos vestibulares, daqui a três anos, se deparar com a pergunta: quando é que nasceu Newton? Talvez se corra este perigo. Então não é por aí. Não é só ensinar História [da Ciência], senão, aí o aluno vai começar a decorar frases (Zanetic apud Cruz 1988, p.88).
\end{abstract}

Naturalmente, a História e Filosofia da Ciência (HFC) enquanto abordagem didática hoje consolidada no ensino de ciências (EC) tem uma história. Parte desta, em termos de sua presença mais concreta em salas de aula e em documentos oficiais, é relativamente recente - por outro lado, apelos por sua importância de uma forma geral são mais antigos, remontando ao final do século XIX ${ }^{1}$. Matthews (1994) em Science Teaching: The Role of History and Philosophy of Science, uma obra clássica e celebrada como referência sobre a aproximação da HFC ao EC, cita o filósofo austríaco Ernst Mach como um dos primeiros defensores diretos desta aproximação. Para Mach, a História da Ciência (HC) seria importante "a não ser que os princípios nela [ciência] acumulados se transformem num sistema de prescrições imperfeitamente compreendidas ou, pior, num sistema de preconceitos” (idem). William Whewell, Thomas Huxley e John Dewey também entram no rol de nomes de pioneiros no reconhecimento da importância geral da HFC (Matthews 2012, p.3).

Foge do escopo deste trabalho esclarecer de forma exaustiva os inúmeros fatores sejam internos ou externos à academia, adjacentes ou distantes das salas de aula de ciências -, que culminaram para que no início dos anos 1990 a importância da HFC começasse a ser melhor reconhecida e vivesse um boom em especial na academia. As

\footnotetext{
${ }^{1}$ Aprofundarmo-nos exaustivamente na historia da HFC no EC seria bastante proveitoso e propiciaria um insight mais próprio de como essa estratégia de ensino se consolidou de forma tão firme nos últimos anos nessa área. Tal importante exercício, porém, foge do escopo deste trabalho - todavia, como usual de trabalhos deste tema na área de pesquisa em EC, apresentamos em trabalho anterior (Noronha 2014) considerações mais espaçadas sobre a questão. Por outro lado, importantes obras tais como Matthews (1994; 2014; 2017) cumprem o papel de fornecer imagens razoáveis tanto da história da HFC (enquanto estratégia didática) como de um panorama atual de sua presença no EC.
} 
criações do periódico Science \& Education (1992) - um dos maiores até hoje na área de pesquisa em EC - e do grupo International History, Philosophy and Science Teaching Group (1987) contribuíram para amadurecer ainda mais esse ramo de pesquisa no EC. Não é difícil se concluir, averiguando publicações da área, dissertações e teses, e também nos principais congressos e seminários, que existe um consenso bastante forte entre pesquisadores em EC acerca da importância da aproximação da HFC ao ensino de ciências (ver Matthews 1994; Martins 2007; Forato 2009; Vilas-boas et al. 2013; Matthews 2014; Matthews 2017). Todavia, apesar da força deste discurso, como qualquer outra abordagem didática, experiências 'positivas' de HFC no EC têm diversos condicionantes - diariamente postos em evidência por professores e pesquisadores - tais como boas estruturas educacionais (em termos de sala de aula, mas também em níveis burocráticos e organizacionais), formação histórico-filosófica adequada de professores, existência de materiais histórico-filosóficos (Peduzzi 2005), entre outros. Em outra direção, Höttecke e Silva (2011, p.303) comentam que os currículos tendem a não especificar o conteúdo de HFC, o que faz com que professores fiquem sem subsídios para trabalha-la em sala de aula e que deem preferência para 'pontos importantes' do documento. Sobreposto a estes pontos, tem-se que a HFC não pode ser entendida como a panaceia dos (incontáveis) problemas educacionais especificamente no EC (Zanetic apud Cruz 1988, p.88) - é neste sentido que Matthews (1994) sugeriu modéstia nos propósitos da HFC na educação científica. Tendo em mente alguns problemas específicos no EC como a insistência da presença de visões distorcidas sobre a ciência - a abordagem HFC pode ser entendida no melhor dos casos como necessária, mas não suficiente (Noronha 2014).

Os apelos pela aproximação da HFC ao EC ao longo dos últimos trinta anos se consolidaram e se tornaram muito comuns em trabalhos nestes temas ou correlatos, tornando-se por vezes quase como uma 'retórica acadêmica obrigatória'. É bastante comum, por exemplo, a menção de que a HFC podem humanizar a ciência:

(...) e conectá-la a questões pessoais, éticas, culturais e políticas. Há evidências de que [a HFC] tornam programas [educacionais] de ciência e engenharia mais atrativos para muitos estudantes, e em particular as meninas, que frequentemente rejeitam-nas, (...) podem melhorar a educação de professores ajudando-os a desenvolver um entendimento mais rico e autêntico da ciência e seu lugar no cenário intelectual e social das coisas. Isto tem um efeito dominó, assim como há evidências de que a epistemologia dos professores, ou suas 
concepções sobre a natureza da ciência, afeta como eles ensinam (Matthews 1993, 358).

Ou, ainda, que a ciência, por meio do ensino sobre a ciência, deve ser compreendida como um empreendimento humano:

(...) praticado em um contexto cultural maior e que seus praticantes [cientistas] são produtos desta cultura, (...) [e] que a ciência afeta e é afetada por vários elementos e esferas intelectuais da cultura na qual está inserida. Esses elementos incluem (...) estruturas de poder, política, fatores socioeconômicos, filosofia e religião (Lederman 2007, p.834).

Entretanto, apesar da reconhecida importância - pelo menos em termos da numerosa quantidade de referências acadêmicas na área de EC -, a HFC colecionou também nos últimos decênios algumas críticas negativas à sua implementação. Entre elas, o alerta de Allchin (2004) acerca do caso em que a aproximação da HC e EC é feita de forma descuidosa, podendo trazer o risco da 'pseudo-historização'. Numa linha semelhante, há quase quarenta anos, Whittaker (1979) acusava o que chamou de ‘quase-historização’ da ciência, fenômeno ainda presente em muitos livros-texto de física - uma versão desfocada da reconstrução racional discutida por Lakatos (1970). A título de exemplo de outras críticas, tem-se a tese de que a HFC no EC poderia enfraquecer ou relativizar a visão de ciência entre estudantes (Peduzzi 2005, p.152) e, principalmente, de que a HFC enquanto uma abordagem que demanda certo número de condições, entre elas, por exemplo, um relativo domínio do professor sobre o tema - é impossibilitada devido à falta de tempo e condições para aplicação em sala de aula. Em contraposição, diversos trabalhos relevantes - tais como o de Matthews (1994) - procuraram reforçar e defender o lado positivo de tal aproximação, a qual, em ressonância parcial aos apelos usuais exemplificados anteriormente: facilitaria a compreensão da ciência, enquanto construção humana; instigaria à interdisciplinaridade (Matthews 1993, p.361); permitiria um diálogo entre o desenvolvimento histórico da ciência e o processo de aprendizagem dos estudantes; ajudaria na compreensão dos conceitos científicos e o desenvolvimento do raciocínio crítico (Matthews 1995, p.182); auxiliaria a uma compreensão menos ingênua sobre a ciência, entre outros.

Tais pontos positivos acima, consagrados pela literatura da área, tornaram-se lugar comum e por vezes, no que se refere o seu frequente emprego na literatura, amparam-se 
mais na própria retórica de si mesmos do que em evidências empíricas gerais - muito embora existam trabalhos, como ilustrado por Matthews (1993), que já há mais de vinte anos, apontam evidências locais que pareçam corroborá-los. De qualquer forma, é seguro afirmar que há hoje um consenso (muitas vezes tácito e não explicitamente declarado) de que a HFC traz mais benefícios do que malefícios no EC. Por outro lado, a despeito da existência de consensos, as tensões entre historiadores da ciência e professores e educadores em ciência não deixam de existir. Grande parte destas tensões se dá em razão dos (esperados) desencontros entre demandas historiográficas e demandas educacionais (ver Forato 2009). Nesta direção, há quase meio século, Brush (1974) advertia que professores de ciência que quisessem introduzir a HC em suas aulas deveriam se atentar às tendências historiográficas modernas, o que chama de 'nova história da ciência' segundo ele caracterizada pela crítica à objetividade científica, a valorização de uma dimensão subjetiva nos processos de validação de teorias, o ataque às concepções estritamente empíricas da origem do conhecimento científico, entre outras (ibid., p.1168). Reconhecendo dificuldades inerentes à aproximação da HC ao EC - e que, enquanto estratégia de ensino, ela não é neutra quanto aos objetivos educacionais implícitos ou explícitos -, sugere (ibid., 1176):

[...] [P]ara o professor que não deseja desdoutrinar seus estudantes da ideia tradicional de cientista como um descobridor neutro de fatos, não usar materiais históricos do tipo que são preparados por historiadores da ciência: eles não servirão ao seu propósito. [...] Por outro lado, aqueles professores que querem contrapor o dogmatismo presente nos livros didáticos e transmitir algum entendimento da ciência enquanto atividade vinculada a considerações metafísicas e estéticas encontrarão estímulo na nova história da ciência ${ }^{2}$.

Considerações semelhantes foram feitas também para FC e sociologia da ciência (ver Allchin 2003, 2004b).

Além da aproximação de HFC no EC, discussões sobre aquilo que é cunhado de Natureza da Ciência (NdC) - um termo que hoje muitas vezes é designado como conhecimento sobre a ciência - também tomaram espaço relevante no âmbito educacional

\footnotetext{
${ }^{2} \mathrm{O}$ reconhecimento de que a HC pode desdogmatizar visões pouco críticas sobre a ciência é um apelo que, por vezes, também surge em cientistas, não apenas historiadores da ciência ou educadores. Como exemplo local, Mário Schoenberg, importante cientista brasileiro, em ressonância à sugestão de Brush, afirmou quarenta anos atrás que seria importante jovens estudantes universitários terem contanto com HC em razão do ensino universitário ser extremamente dogmático (uma afirmação infelizmente ainda bastante atual) (Zanetic 1989).
} 
pedagógico. A despeito de gozar de uma enorme popularidade para alguns segmentos da área de pesquisa em EC, a NdC é difícil de ser definida em termos gerais - não faltam, porém tentativas, mais ou menos felizes, como a de Moura (2014, p.32):

\begin{abstract}
A natureza da Ciência é entendida como um conjunto de elementos que tratam da construção, estabelecimento e organização do conhecimento científico. Isto pode abranger desde questões internas, tais como método científico e relação entre experimento e teoria, até outras externas, como a influência de elementos sociais, culturais, religiosos e políticos na aceitação ou rejeição de ideias científicas.
\end{abstract}

Em parte, o interesse educacional por tais discussões envolvendo conhecimentos metacientíficos foi reforçado por importantes debates entre estudiosos (incluindo-se filósofos, sociólogos e em especial historiadores da ciência) acerca da ciência aproximadamente a partir da segunda metade do século passado, contexto no qual importantes questões foram recuperadas e reestudadas à luz de novas escolas historiográficas e filosóficas. Repercussões de tais debates e seus desdobramentos influenciaram fortemente outras áreas, entre elas a de pesquisa em EC - muito embora Lederman (2007) e Jenkins (2013) argumentem que a presença de apelos em prol do que hoje chamamos NdC já podem ser encontrados em documentos curriculares estadunidenses quase centenários ${ }^{3}$. Isto, aliado a outros fatores, culminou no fenômeno da aceitação cada vez mais unânime entre pesquisadores em EC de que uma educação científica plena e crítica não deve se limitar à compreensão da ciência, mas contemplar também o conhecimento sobre a ciência - o que incluiria sua história e filosofia, seus métodos, seu funcionamento, seu valor social e tecnológico, suas relações com outros campos como religião e cultura, entre outros (idem).

A importância da NdC no EC, hoje relativamente consolidada, foi se construindo historicamente em especial ao longo da segunda metade do século passado, de forma gradual até atingir a força hoje verificada em eventos especializados e periódicos da área. Dentre os diferentes motivos pelos quais a NdC é defendido atualmente na educação científica, um deles - e talvez o principal - é a presença ainda bastante frequente de concepções ingênuas (ou inadequadas) sobre ciência em estudantes e professores (e também cientistas) (Lederman 1992; Abd-El-Khalick \& Lederman 2000) - e, por

\footnotetext{
${ }^{3}$ Muito embora a noção de NdC estivesse mais associada a atividades experimentais e laboratoriais, onde os estudantes poderiam então tomar contato com ‘o método científico’ (ver Jenkis 2013).
} 
extensão, também em livros didáticos e outros documentos educacionais, como currículos. Tais concepções, do ponto de vista filosófico, costumam orbitar concepções que podem ser classificadas de empirismo ingênuo, racionalismo ingênuo, ou ainda, realismo (ou antirrealismo) ingênuos (ver Noronha 2014). De uma ótica política, argumenta-se que essas concepções são desinteressantes à formação de cidadãos conscientes e críticos (ver Aikenhead 2006; Hodson 2014), problemática esta que se reflete, por exemplo, em considerações e orientações em documentos curriculares oficiais.

Além dos ambientes escolares, também muitos discursos em divulgações científicas sejam escritas, visuais, telejornalísticas e semelhantes - tendem a reforçar concepções ingênuas sobre a ciência (ver Cardoso et al. 2015). Com efeito, um dos principais educadores e pesquisadores da área de EC envolvido no escrutínio de aproximar HFC e NdC às salas de aula de ciências, Allchin (2013) reforça que a necessidade da NdC na educação científica fica evidente pela forma do contato das pessoas com notícias referentes a questões científicas, não só pelas vias educacionais, mas também pela mídia:

Em qual tipo de expert confiar? Quais apresentações públicas sobre descobertas científicas são confiáveis? Como cientistas chegam a conclusões sobre coisas que eles não podem ver diretamente? Quando é justificada, ou não, uma mudança em uma questão científica consensual? Como podem os cientistas cometer erros honestos, e como se pode avalia-los? Esses casos evidenciam as metas do letramento científico. (...) informar sobre decisões da vida real, seja públicas ou pessoais, é preciso conhecimento sobre como a ciência funciona. Conhecimento da NdC deve ser tão importante - se não mais importante - que o conhecimento dos conteúdos (ibid., p.9).

O apelo de Allchin que a NdC é tão ou mais importante que o conhecimento dos conteúdos tradicionais é repetido independentemente por outros autores (Lederman 2007), em especial estadunidenses. Porém, o consenso acerca da importância da inclusão de tópicos e conhecimentos da NdC no EC não responde por si só a questão central sobre o quê se considerar ou ensinar sobre $\mathrm{NdC}$, seja implícita ou explicitamente, por vias instrucionais ou investigativas, entre outros. Com efeito, parte considerável do esforço envolvido ao longo de decênios no amadurecimento dos debates sobre NdC por pesquisadores em EC envolveu a questão de conceitualizar seu conteúdo atendendo a diversos fatores - entre eles, a exequibilidade didática e a concordância com correntes 
críticas recentes entre historiadores, filósofos, sociólogos da ciência e outros estudiosos metacientíficos.

\subsection{A falta de consenso sobre o conteúdo da natureza da ciência}

Parte da necessidade em se construir uma abordagem consensual didatizada sobre o conteúdo da NdC no EC seria em razão do caráter altamente controverso que as discussões englobadas pela NdC possuem na FC (o que, a rigor, é ao mesmo tempo uma crítica a tal tentativa de procurar consensos). Isto aliado, implicitamente, a teses de que controvérsias filosóficas são desinteressantes ao ensino de ciências (ver Alters 1997a, 1997b; Eflin, Glennan \& Reisch 1999; Bagdonas \& Silva 2013; Bagodnas et al. 2017; Noronha, Bagodnas \& Gurgel 2018). Por isso, autores apontaram positivamente para elementos da NdC que seriam 'menos controversos' - ou, mais consensuais entre estudiosos de disciplinas metacientíficas ${ }^{4}$ - e que poderiam, portanto, serem trabalhados no EC (Smith et al 1997). A título de exemplo, Gil-Pérez e colaboradores (2002, p.563), visando combater o que chamam de 'epistemologia espontânea' nos alunos, argumentam que poderia existir uma base comum para a NdC pautada em trabalhos centrais de Karl Popper, Thomas Kuhn, Paul Feyerabend, e outros.

Todavia, entre diversas propostas de consenso que foram sendo construídas nos últimos anos, as de McComas (1998), McComas, Clough e Almazroa (1998) e Lederman e colaboradores (1992; 1998; 2002) certamente tiveram impacto singular na área. O esforço destes e diversos outros autores, ao longo de quase vinte anos de pesquisa, culminou no que ficou conhecido recentemente como Visão Consensual da Natureza da Ciência (VCNdC). De forma bastante resumida, tais propostas consistem numa apresentação de listas de proposições curtas e objetivas - e, em geral, descontextualizadas -, em especial a proposta de Lederman e colaboradores (2007). Anos depois, a lista de Lederman - ou os 'setes pontos de Lederman' (Lederman's seven) como foi cunhado por (Matthews 2012) -, é ainda tida como um dos marcos mais importantes na pesquisa em

\footnotetext{
${ }^{4}$ Essa colocação não significa, contudo, que necessariamente 'controvérsia' é o antônimo de 'consenso' no que tange conteúdos de NdC no EC, muito embora seja uma associação relativamente recorrente.
} 
ensino de ciências, em particular na área da aproximação de HFC e NdC ao ensino de ciências. Em suma, os sete pontos são, segundo esclarecimentos de Matthews (2012):

1. A natureza empírica da ciência, no qual eles [Lederman e colaboradores] reconhecem que embora a ciência seja empírica, cientistas não têm acesso direto à maioria dos fenômenos naturais (...).

2. Teorias científicas e leis, no qual eles defendem que 'leis são descrições de relações entre fenômenos observáveis... Teorias, por outro lado, são explicações inferidas dos fenômenos observados ou das regularidades nestes fenômenos... Teorias e leis são formas diferentes de conhecimento e um não se torna o outro' (...).

3. A natureza imaginativa e criativa do conhecimento científico, no qual eles defendem que 'a ciência é empírica... Contudo, a geração de conhecimento científica também envolve imaginação humana e criatividade. Ciência... não é uma atividade ordenada, inteiramente racional e sem vida... entidades científicas, como os átomos e espécies, são antes modelos teóricos funcionais do que cópias da realidade’ (...).

4. A natureza teórico-dependente do conhecimento científico, no qual se defende que 'as asserções teóricas ou disciplinares dos cientistas, crenças, conhecimentos anteriores, treinamento, experiências e expectativas influenciam em seu trabalho. Todos esses fatores de fundo formam um estado de ser que afeta os problemas que os cientistas investigam e como eles conduzem suas investigações' (...).

5. O enraizamento social e cultural do conhecimento científico, no qual é defendido que 'Ciência, enquanto empreendimento humano, é praticada em um contexto de uma cultura maior e seus praticantes são o produto desta cultura. Isto implica que a Ciência afeta e é afetada pelos vários elementos e esferas intelectuais da cultura na qual está enraizada’ (...)

6. O mito do método científico, no qual se defende que 'não há um único método que poderia garantir o desenvolvimento de um conhecimento infalível... e não há uma sequência simples de atividades... que leva [os cientistas] indubitavelmente a respostas ou soluções válidas ou funcionais'.

7. A natureza provisional do conhecimento científico, no qual se argumenta que 'conhecimento científico, embora confiável e durável, não é nunca absoluto ou 
definitivo. Esse conhecimento, incluindo os fatos, teorias e leis, está sujeito a mudanças’ (...) (ibid., p.10-11).

Além destes, se considerarmos conjuntamente propostas recentes de McComas (McComas \& Nouri 2016), esta lista se amplia para doze itens:

8. O conhecimento científico não é totalmente objetivo.

9. Ciência não pode responder a todas as perguntas.

10. Cooperação e colaboração são partes do desenvolvimento do conhecimento científico.

11. Há distinções entre ciência e tecnologia.

12. Experimentos são fundamentais para a ciência.

Em diferentes ocasiões, Lederman e colaboradores e outros autores centrais para a VCNdC declaram explicitamente que sua proposta não é, em princípio, uma tentativa de caracterização única do que seria a NdC, e que estariam cientes que seu conteúdo poderia mudar com o tempo, sendo que, a forma como está sendo proposta há de fazer sentido apenas para o contexto atual (Abd-El-Khalick \& Lederman 2000; Lederman 2007; Lederman \& Lederman 2014). Contudo, é fundamental notar que as listas acima, na forma como são usualmente apresentadas, carregam um direcionamento normativo em razão da natureza direta, curta e descontextualizada de suas proposições - ou, como alguns críticos à abordagem VCNDC tem enfatizado na literatura recente, de seus tenets sobre o conteúdo da $\mathrm{NdC}^{5}$.

Embora as listas de VCNdC apresentem um grande potencial didático principalmente quanto a avaliações e estudos de concepções de ciência por meio de questionários padronizados e consolidados na literatura especializada (ver Abd-ElKhalick 2012, 2014; Lederman et al 2002; Lederman, Bartos \& Lederman 2014) -, não demorou para que logo se identificassem fragilidades no corpo e conteúdo da proposta, principalmente do ponto de vista filosófico. De fato, como Eflin, Glennan e Reisch (1999) enfatizaram antes mesmo da consagração da VCNdC na área de pesquisa, as ciências comporiam um fenômeno cultural bastante difuso para ser caracterizado como contendo

\footnotetext{
${ }^{5}$ Uma tradução ao português para este termo seria ‘princípio ou crença central para um grupo', ou ainda 'dogma'. Consideraremos neste trabalho, além da primeira tradução ilustrada, a noção de que tenets são asserções curtas e simples (no nosso contexto, asserções sobre o conteúdo da NdC).
} 
uma 'única natureza'. Este é exatamente o ponto de Jenkins (2013, p.146), para quem quaisquer tentativa de conceber a $\mathrm{NdC}$ de forma geral para todas as ciências está destinada ao fracasso - dadas inúmeras diferenças metodológicas, conceituais, linguísticas e filosóficas entre elas -, e, também, qualquer tentativa de delineá-la exclusivamente em termos teóricos-intelectuais.

A onda de críticas à abordagem consensual nos últimos anos se tornou tão notável quanto os esforços em aproximar a VCNdC a intervenções didáticas locais e propostas curriculares. Resumidamente, o conjunto dos sete pontos de Lederman tem sido duramente criticado principalmente do ponto de vista filosófico (Irzik \& Nola 2011; 2014; Matthews 2012; Allchin 2013; Martins 2015; Dagher \& Erduran 2016) - em especial, por supostamente carregarem uma postura 'essencialista' sobre a caracterização do fazer e saber científicos (ver figura 1). Intentaremos, nos próximos parágrafos, apresentar de forma resumida e rápida os pontos centrais das principais críticas recentes à abordagem da VCNdC.

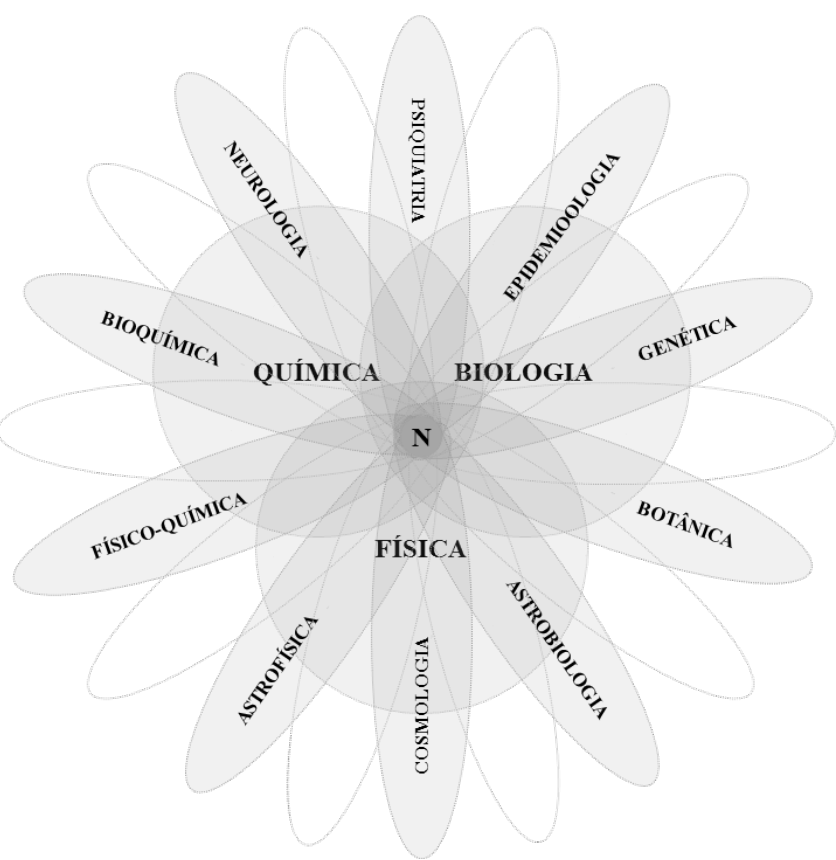

Figura 1: Representação imagética de uma abordagem essencialista de NdC. Adaptado de Noronha (2014). As ciências ilustradas na figura foram escolhidas aleatoriamente. $\mathbf{N}$ representaria um (suposto) núcleo essencial compartilhado por todas as ciências, segundo esta abordagem.

Irzik e Nola (2011; 2014) criticam a visão consensual da NdC de Lederman por esta supostamente se aproximar de um essencialismo que, na realidade, parece não existir em uma forma trivial. Buscando uma imagem de Ciência que não seja dinâmica somente no tempo, mas também no espaço das ciências, Irzik e Nola usam o conceito de semelhanças 
de família, inspirados na obra de Ludwig Wittgenstein, para compor uma nova abordagem de NdC que faça justiça às diferentes formas de ciência e suas especificidades - especificamente, utilizam a abordagem semelhanças de família do tipo ‘politética'. Em suma, para os autores ‘ciência’ não teria uma definição precisa e exata, mas congregaria necessariamente variações de quatro categorias: (i) atividades como observar, fazer experimentos, classificar e levantar problemas; (ii) objetivos e valores como explicação, previsão e simplicidade; (iii) metodologias e regras metodológicas como indução, método hipotético-dedutivo e analogias; (iv) produtos como hipóteses, teorias, leis, modelos e dados experimentais. Importa frisar, ainda, que os aspectos associados à historicidade do conhecimento científico, ao enraizamento social e cultural do conhecimento científico, às práticas científicas e à criação de conceitos, modelos e teorias são menos enfatizados pelos autores (ver figura 2).

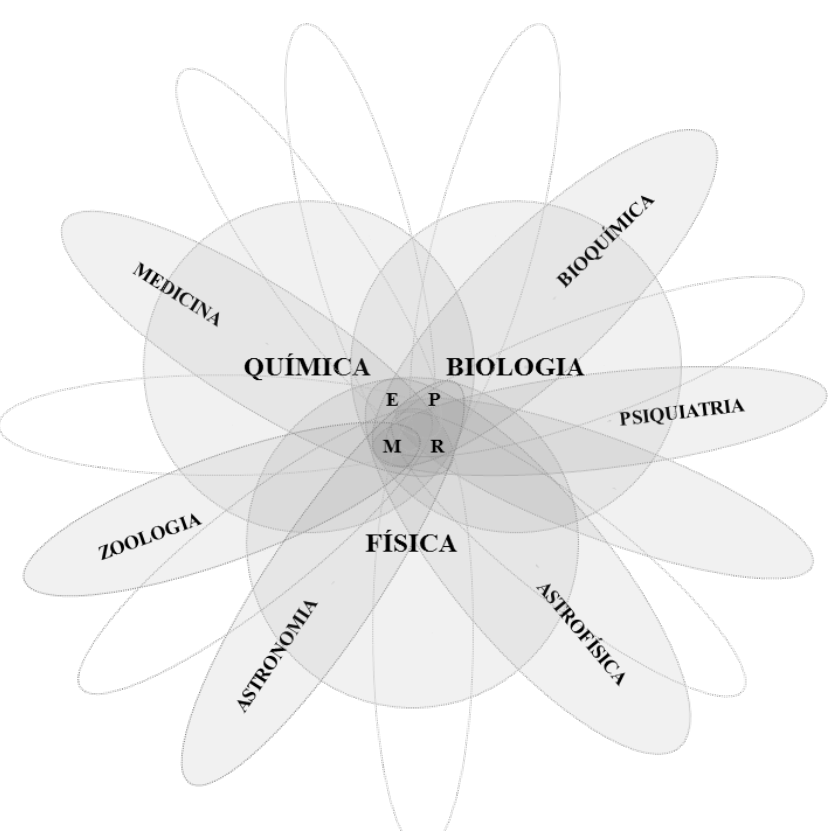

Figura 2: Representação imagética de uma abordagem semelhanças de família do tipo politética da NdC. Adapatado de Noronha (2014). Na figura acima, A representa a primeira categoria estabelecida por Irzik e Nola (2011;2014) - '(i) atividades como observar, fazer experimentos, classificar e levantar problemas'; O, '(ii) objetivos e valores como explicação, previsão e simplicidade’; M, '(iii) metodologias e regras metodológicas como indução, método hipotético-dedutivo e analogias', e; P, '(iv) produtos como hipóteses, teorias, leis, modelos e dados experimentais'. As ciências ilustradas na figura foram escolhidas aleatoriamente, e a falta de rigor quanto a caracterização destas com relação às categorias desta abordagem reflete o objetivo meramente didático desta representação imagética neste ponto.

Matthews (2012) propõe uma mudança de termos, de 'natureza da ciência' para 'características da ciência' (features of science), argumentando que seria mais interessante discutir, investigar e formular características da ciência do que se ensinar sua (suposta) natureza (ibid., p.18). Assim feito, os sete pontos de Lederman se tornam vários 
pontos, alguns consensuais e outros não consensuais, muitos levantados pelos atuais estudos em HFC e também em Sociologia da Ciência. Cada um, segundo Matthews, com um enorme aporte histórico-filosófico e potencial de discussão (ibid., p.18-20). Apesar da relevância de sua crítica, sua sugestão de nomenclatura ainda tem tido pouco efeito (ou adeptos) na área (Romero-Maltrana et al. 2017).

Allchin (2013; 2011) é um importante e reconhecido critico da apresentação da NdC na forma de princípios abstratos, que funcionam como uma lista para memorização (ibid., p.x). De acordo com o autor, há muito a se desaprender sobre NdC (idem). Embora reconheça a utilidade da lista em algumas situações, Allchin enfatiza seus problemas, uma vez que as ideias sobre ciência precisam de contextos e exemplos concretos (ibid., p.13). Outros elementos, defende o autor, tais como o papel do financiamento na ciência, motivações, revisão de pares, processos cognitivos inerentes, existência de fraudes e validação de novos métodos, precisam ser caracterizados como NdC (ibid., p.18). Allchin defende que uma maneira de aprender as características centrais de como a ciência funciona é equipar os estudantes para que possam avaliar evidências por eles mesmos, fazer julgamentos que os cientistas fazem. E, por conveniência, apresenta essas características em forma taxonômica:

[Dimensão observacional] Observações e medidas: - Acurácia, precisão (...) Papel do estudo sistemático (versus anedota) (...)- Completude das evidências (...)- Robusteza (concordância entre vários tipos de dados)

Experimentos: - Experimento controlado (de uma variável) (...)- Estudos de tipo duplo-cego (...)- Estudo estatístico dos erros (...)- Replicação e tamanho da amostra (.) Instrumentos: - Novos instrumentos e sua validação (...)- Modelos e organismos de modelo (...) - Ética da experimentação em questões humanas

[Dimensão conceitual] Padrões de pensamentos: - Relevância das evidências (empirismo) (...) - Informação verificável versus valores (...) - Papel da probabilidade na inferência (...) - Explicações alternativas (...) - Correlação versus causa

[Dimensões históricas] Consiliência com evidências consolidadas (...) - Papel da analogia, pensamento interdisciplinar (...) - Mudança conceitual (...) - Erro e incerteza (...) Papel da imaginação e síntese criativa (...) 
[Dimensões humanas] Espectro de motivações para fazer ciência (...) Espectro de personalidades humanas (...) - Papel de crenças anteriores (...) Emoção versus percepções de risco baseadas em evidências.

[Dimensão sociocultural] Instituições: - Colaboração e competição entre os cientistas (...) - Formas de persuasão (...) - Credibilidade (...) - Revisão de pares e respostas a críticas (...) - Resolução de desacordos (...) - Liberdade acadêmica (.) Tendenciosidades: - Papel das crenças culturais (ideologia, religião, nacionalidade, etc.) (...) - Papel dos preconceitos de gênero (...) Papel dos preconceitos de raça e classe (.) Financiamento: - Fontes de financiamento (...) - Conflitos pessoais ou de interesse (.) Comunicação: Normas para tratar com dados científicos (...) - Natureza dos gráficos (...) Credibilidade dos vários jornais científicos e noticiários (...) - Fraude e outras formas de conduta negativa (...) - Responsabilidade social dos cientistas (ibid., p.24)

O autor defende que esta matriz deve ser vista como uma referência - um argumento também feito por Lederman e Lederman (2014) em defesa a sua abordagem -, e que seus tópicos podem ser tratados de forma separada quando forem propícios para uma compreensão mais profunda da NdC (ibid., p.26). Ainda, indica que podem ser feitos em aplicações com investigações dos estudantes ou em estudos de caso com casos históricos ou contemporâneos. Allchin (idem) nomeia sua abordagem como Whole Science Framing (ou, Abordagem Integral da Ciência), a qual configura com uma das alternativas mais conhecidas às listas de Lederman e McComas, ainda que seja isento de críticas dos defensores da visão consensual (ver Schwartz, Lederman \& Abd-El-Khalick 2012).

Em um trabalho anterior (Noronha, 2014), incorporamos a crítica de Irzik e Nola (2011), sugerindo, todavia, uma reinterpretação da tese destes autores quanto à abordagem wittgensteiniana. Criticamos, contudo, o modelo destes autores por utilizarem a abordagem por semelhanças de família do tipo 'politética', uma vez que suas categorias fundamentais eventualmente podem ser entendidas como essenciais e a-históricas à caracterização da ciência, no caso de tal abordagem não ser feita de forma bastante atenta e crítica. Argumentamos (idem) que a abordagem por semelhanças de família do tipo 'série’ poderia ser mais interessante para representar as características da ciência e suas diferentes disciplinas. Nesta abordagem, as diferentes disciplinas ou áreas científicas não compartilham necessariamente de um mesmo conjunto de características - há apenas semelhanças entre pares ‘próximos’ (ver figura 3). Entretanto, a escassez de trabalhos na literatura abordando tal proposta apenas reforça o quão não trivial é trabalha-la no EC. 


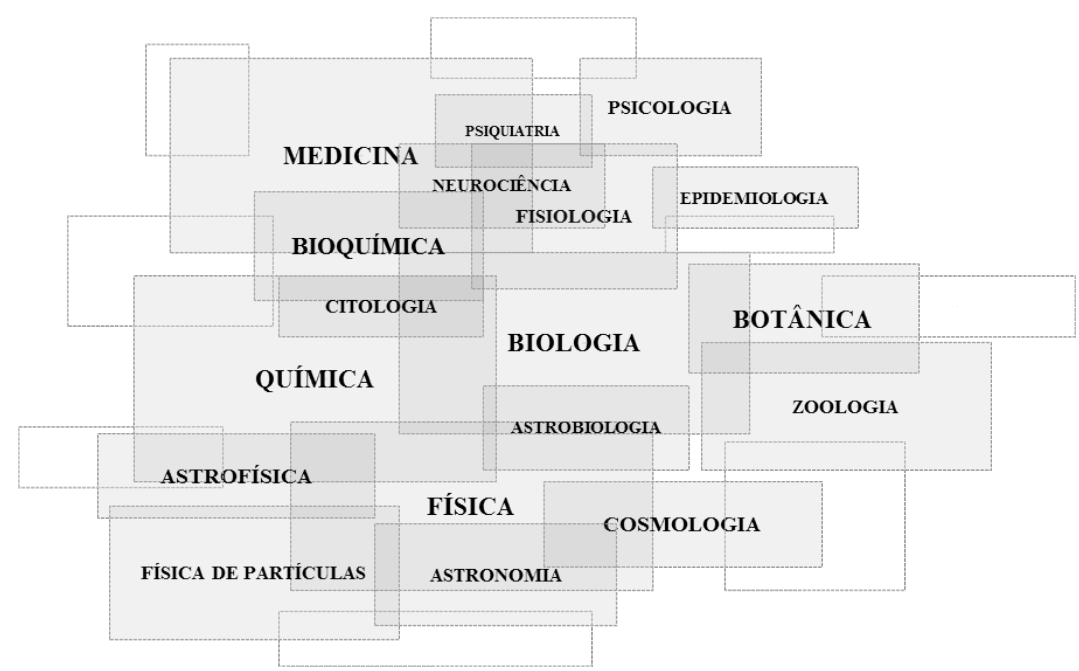

Figura 3: Representação imagética da abordagem semelhanças de família do tipo série da NdC. Adaptado de Noronha (2014). As ciências ilustradas foram escolhidas aleatoriamente. Assim como na figura anterior, a falta de rigor quanto à pertinência ou não das interseções entre as ciências na figura é compensada pelo objetivo meramente didático desta representação imagética desta abordagem. O mesmo pode ser dito sobre as 'posições' das ciência no espaço representado.

Martins (2015), partindo das críticas à visão consensual da NdC, e ao fato de que um consenso ao nível filosófico é inatingível, e que qualquer conteúdo a ser ensinado passa necessariamente por transformações didáticas, elabora uma proposta de abordagem da $\mathrm{NdC}$ com base em temas e questões. É crítico à abordagem de tenets, e segundo o autor, a abordagem de Lederman pode levar a um relativismo exacerbado, por suas afirmações darem margens a interpretações descuidadas sobre os papéis da subjetividade no fazer científico. Visando contornar tais problemas, o autor apresenta uma proposta que tem eixos norteadores (eixo sociológico e histórico, e eixo epistemológico), mudando então a forma e conteúdo da perspectiva de trabalho com a NdC. Martins exemplifica por meio de uma tabela (tabela 1) os eixos e questões referentes à abordagem da NdC que propõem.

Martins (ibid., p.730) argumenta que esta abordagem supera muitas críticas feitas à VCNdC, enquanto ao mesmo tempo preserva o conhecimento construído na área de pesquisa sobre o tema. Enfatiza também a importância da formação de professores em HFC para a realização concreta das diferentes abordagens de NdC no EC (ibid., p.731). Sua proximidade à proposta de Allchin, contudo, pode tornar esta abordagem criticável por defensores da visão consensual no sentido de ser muito ampla e pouco específica do ponto de vista didático-pedagógico (ver Moura 2014). Por outro lado, sua abordagem sofre 'desvantagem' frente à VCNdC, no sentido desta ser melhor adaptada a testes e modelos tradicionais de ensino - infelizmente, ainda os mais comuns 
Eixos epistemológicos

Eixo sociológico e histórico
Problema da origem do Métodos,

procedimentos e processos da ciência conhecimento

(científico)
Conteúdo / natureza do conhecimento produzido
- Papel dos

indivíduos/sujeitos e da

comunidade científica

- Intersubjetividade

- Influências históricas

e sociais

- Questões morais, éticas e políticas

- A ciência como parte de uma cultura mais ampla

- Objetivos da ciência / objetivos dos cientistas

- Comunicação do conhecimento científico dentro da comunidade científica e em domínio público

- Controvérsias

históricas e

contemporâneas na

ciência

- Ciência e outros tipos

de conhecimento

- Ciência e tecnologia

\author{
- Coleta, interpretação, \\ análise e avaliação dos \\ dados \\ - Modelagem \\ - Observação e \\ inferência \\ - Hipóteses, previsões e \\ testes \\ - Correlação e \\ causalidade \\ - Natureza da \\ explicação em ciência \\ - Avaliação de teorias \\ -Papel das analogias, \\ imaginação e \\ criatividade \\ - Visão do senso \\ comum sobre o método \\ científico (sequência \\ passo-a-passo) \\ - Ciência e outros tipos \\ de conhecimento
}

\author{
- Leis e teorias - \\ Postulados \\ - Noção de modelo \\ científico \\ - Papel da Matemática \\ - Poder e limitações do \\ conhecimento científico \\ - Ciência e outros tipos \\ de conhecimento \\ - Ciência e tecnologia
}

Tabela 1: Abordagem da Natureza da Ciência por temas e questões (Martins, 2015).

.Inspiradas nas críticas de cunho filosófico de Irzik e Nola à proposta de Lederman, Dagher e Erduran (2016) aprimoram o que chamam abordagem por semelhanças de família da NdC. Basicamente, as autoras defendem que o propósito desta abordagem é promover uma compreensão holística e contextualizada da ciência. Argumentam que, por ser sugestivo e não prescritivo, esta abordagem oferece aos professores um escopo maior de escolhas no que se refere a como inserir elementos da NdC com base nas categorias elencadas: objetivos e valores; métodos e regras metodológicas; conhecimento; práticas; disseminação e certificação social; valores sociais; ethos científico; atividades profissionais; estruturas políticas de poder; sistemas de financiamento, e; organizações sociais e interações. Importa sublinhar que as autoras sugerem a preservação de um núcleo caracterizador da $\mathrm{NdC}$, muito semelhante àquele da proposta de Irzik e Nola (2011) - isto é, mantém, de certa forma, a abordagem de semelhanças de família tipo politética. 


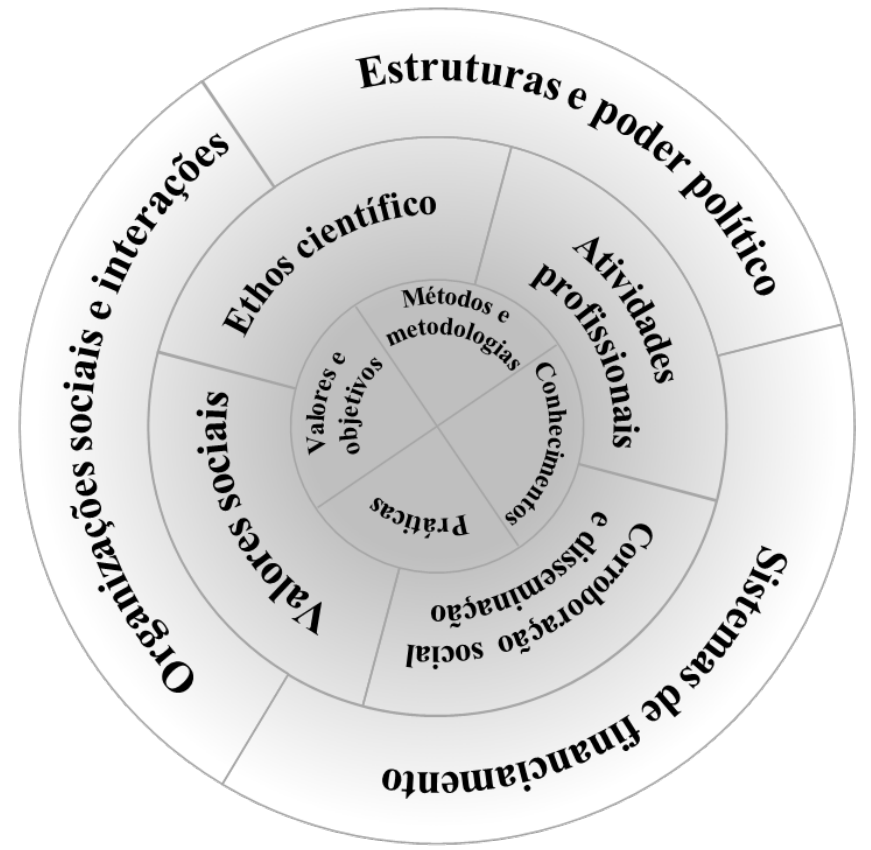

Figura 4: A 'roda’ da abordagem semelhanças de família da NdC. Adaptado e traduzido de Dagher e Erduran (2016).

Existem inúmeras alternativas à VCNdC não mencionadas aqui. Muitas delas seguem direcionamentos nos trabalhos de Irzik, Nola, Dagher e Erduran. Há também propostas autênticas, porém ainda sem muita relativa visibilidade - ver, por exemplo, Yacoubian (2015). De qualquer forma, é lamentável como, pelo menos nas obras mais discutidas neste debate, pouco é discutido sobre problemas sociais urgentes e o que o EC pode fazer por elas.

\subsection{A miséria da natureza da ciência}

O título desta seção final deste capítulo é, em partes, uma referência à importante obra de Karl Marx, Miséria da filosofia (Misère de la philosophie) publicada em 1847. Tratouse de uma resposta à obra do filósofo francês Pierre-Joseph Proudhon, Filosofia da Miséria (Philosophie de la misère) - na qual, conforme intenta resumir Netto (1985, p.17), se defende que as doutrinas antinômicas economia política (capitalista) e socialismo (utópico) resolvam-se numa conciliação em direção a uma 'lei orgânica da humanidade’. A crítica de Marx, uma vez testemunhado, de acordo com Neto (idem), sua evolução intelectual em especial nos Manuscritos de 1844 e em Teses sobre Feuerbach 
(Thesen über Feuerbach, publicado apenas em 1888), direciona-se ao reformismo proudhoniano e à tese de que é na supressão da alienação (realidade expressa pela economia política) que reside a garantia do humanismo real. Com efeito, alinha-se a ela de forma ímpar a (relativamente) conhecida décima primeira tese sobre Feuerbach por Marx, "[f]ilósofos se limitaram a interpretar o mundo de diversas maneiras; mas o que importa é transformá-lo".

Muito longe da intenção de estabelecer uma analogia direta, dado que para este trabalho isto seria um exercício complexo e certamente insuficiente dado seus limites em razão, entre outros fatores, das enormes transformações sentidas pelo marxismo em quase dois séculos (ver Boucher 2015) -, entendemos que no EC, mais especificamente quanto ao debate sobre a $\mathrm{NdC}$, vive-se hoje uma disputa nem sempre explícita entre ‘saídas conciliatórias' e 'saídas supressórias'. A conciliação, no caso, entre ideologias hegemônicas vigentes e utopias - a supressão, por sua vez, destas ideologias por contraideologias. Entendemos que as circunstâncias atuais no EC - e, de certa forma, fenômenos mais gerais envolvendo a educação - permitem uma livre leitura da supramencionada tese sobre Feuerbach: muitos pesquisadores tem-se se limitado somente a interpretar a NdC no EC de diversas maneiras, sendo que o que importa é encontrar maneiras de transformar o EC por ela. Naturalmente, não queremos com isso diminuir eventuais conquistas interpretadas positivamente sobre a aproximação da HFC e NdC no EC. Opomo-nos, contudo, à 'saída conciliatória' adjacente a muitas propostas - em especial a da VCNdC -, por sua complacência a muitas facetas urgentes da realidade educacional - como a mercantilização da educação e a hegemonização de testes padronizados e políticas educacionais neoliberais, conforme discutiremos em capítulos posteriores. A possibilidade de uma ‘saída supressória' nesta questão específica, a qual em tese oferece uma trilha estreita em direção ao 'humanismo real' - ou, à superação da alienação -, além de constantemente resistida, mostra-se enquanto uma tarefa imensuravelmente difícil (ver Apple 2013).

Não obstante as críticas expostas anteriormente à VCNdC, há ainda poucos trabalhos na área que procuram mostrar não só a relevância filosófica de uma visão não consensual da NdC ao ensino de ciências, mas também aquela que chamaremos aqui de relevância política. Embora seja lugar comum os argumentos positivos pela aproximação da HFC e da NdC ao ensino de ciências, argumentos que tenham cunho mais político são ainda raros na literatura - o muito comum discurso sereno e apologético a HFC e NdC, encontrado na literatura da área, raramente toca questões sociais urgentes, como as lutas 
entre classes sociais, os mecanismos de reprodução e recriação social nos ambientes escolares, os problemas sociais advindos e atrelados às grandes avaliações e vestibulares, entre outros. Por vezes alguns destes problemas são reconhecidos (ver Hodson 2014), porém, são relegados ao um plano maior de complexidade, no qual as estratégias de ensino como a HFC - ou 'conhecimentos instrucionais adicionais' como a NdC - teriam pouco ou nada a fazer. Ainda que tal pensamento pareça ser 'realista' e 'sensato' - ou 'modesto', como prescrito por Matthews (1998b) -, urge-se papeis políticos à educação e a ousadia que isto requere. Ainda que a escola não tenha sozinha capacidade de mudar a educação, seus agentes não devem deixar de lado seu papel político e suas possibilidades (ainda que pequenas) de contribuir com a justiça social, entendemos nessa tese que a HFC e a NdC podem, sim, ter um papel político no EC, contribuindo portanto para o esclarecimento de celeumas sociais ocultados (ou não ditos) e enveredar caminhos mais socialmente justos. Nosso ponto é que, a despeito de importantes questões didáticas e pedagógicas adjacentes, apenas as críticas de cunho filosófico à VCNdC não cumprem esta missão, mas sim apenas levam (quando muito) às margens de problemas estruturais maiores. Esta é uma das razões pelas quais buscamos estabelecer uma ponte desta área com a de teorias de currículo.

É importante diferenciar o que estamos propondo - uma aproximação entre os campos de estudo da NdC no EC com teorias de currículo - com questões relativas a sua presença em currículos, documentos educacionais ou discursos curriculares. Com efeito, apelos mais explícitos por pesquisadores à inclusão de aspectos da HFC e NdC em currículos do ensino básico despontavam-se já desde os anos 1960 (ver Connely 1969; Martin 1972; Duschl 1984) ${ }^{6}$. Em reformas curriculares nacionais na década de 1980 - em especial nos contextos estadunidense e britânico encabeçadas respectivamente pela American Association for the Advancement of Science (AAAS) e National Curriculum Council -,

\footnotetext{
${ }^{6}$ Importante mencionar que não raro encontram-se apelos pela HFC na educação em entusiastas desde o fim do século XIX e início do XX, em especial nos contextos britânico (provindos da British Association for the Advancement of Science) e estadunidense. Entretanto, as justificativas para isso eram em geral bastante inesperadas, se tivermos em mente os argumentos contemporâneos - a HC seria um instrumento para que os estudantes aprendessem 'o método científico' (Jenkins 2013, p.134). Especificamente no contexto estadunidense, no início do XX, a 'NdC' era resumida à metodologia científica laboratorial - isto é, no ensino do 'método científico' -, fundado em interpretações frágeis da obra de John Dewey (ibid., p.139). Como se sabe, as duas guerras mundiais e a guerra fria serviram de palco e subterfúgios para reformas educacionais notáveis em ambos os países - o lançamento do satélite Sputnik foi, antes da causa, mais ingrediente neste processo (ver Rudolph 2015)-, como o Physical Science Study Committee (PSSC) (em 1956) e o Harvard Project Physics (iniciado em 1962). Em particular no PSSC pode-se entender que o que se poderia chamar de 'NdC' se caracterizava por 'aprender ciência fazendo ciência', ainda numa ênfase bastante experimental (Jenkins 2013, p.141). O projeto Harvard, por outro lado, desvinculou a HFC de questões exclusivamente laboratoriais, tendo por meio das mãos de Gerald Holton aspectos mais humanísticos e críticos.
} 
aspectos relacionados à HFC já podiam ser encontrados (ver Pumfrey 1991) ${ }^{7}$. Nos anos 1900 e 2000, considerando o enorme crescimento desta subárea na pesquisa em EC, apelos pela HFC (e também a NdC) em currículos e documentos oficiais tornaram-se lugar comum, e, paralelamente, diferentes experiências curriculares (incluindo propostas em currículos locais a documentos nacionais) eram cada vez mais intentadas em diferentes contextos e relatadas na literatura especializada (ver Matthews 1994; McComas \& Olson 1998; Lederman 2007; McComas 2014). Apelos também podem ser encontrados em documentos brasileiros, como os Parâmetros Curriculares Nacionais para o Ensino Médio (Moura 2014, p.37) e as Diretrizes Curriculares Nacionais (DCN) (Brasil 2013) (ver Noronha 2017), ainda que de modo mais contido do que documentos estrangeiros supramencionados.

Jenkins (2013, p.145) é feliz em notar que a curiosa longevidade dos apelos curriculares pró-HFC e NdC no EC provém em parte da sua característica 'tipo slogan', capaz de atrair apoio e interesse mesmo em face da miríade de significados associados a eles. O interesse em aproximar a pesquisa sobre a NdC no EC e teorias de currículo, porém, vai além da questão destas estarem incluídas (ou não) em currículos ou documentos curriculares, assim como as questões envolvendo seus tipos de abordagem e conteúdo. É preciso levar em conta, por exemplo, o impacto e os custos das políticas associadas a estas inclusões, à sua presença em testes padronizados e outras questões mais gerais que transcendem a (importante, porém não suficiente) discussão filosófica acerca do conteúdo da NdC.

De forma generalista, pode-se dizer que atualmente para grande maioria de educadores, pesquisadores e professores envolvidos com teorias de currículo concorda que uma concepção crítica de currículo vai muito além do que a mera organização de conteúdos - currículos trazem consigo, além da 'carga de conteúdo', cargas subjetivas (nem sempre explícitas) envolvendo nuances das mais diversas naturezas, políticas, culturais, ideológicas entre outras (Silva 2010). Estas cargas constituem uma faceta daquilo que se conceitualizou como ‘currículo oculto’ (Moreira \& Candau 2007, p.18) -

\footnotetext{
${ }^{7}$ Como comenta Jenkins (2013, p.142), desenvolvimentos materiais-tecnológicos acelerados, assim como a repercussão de debates acerca da mudança climática, pesquisas biológicas com células-tronco, engenharia genética entre outros, reacendeu a importância do 'letramento científico' e seu papel à formação de cidadãos participantes na sociedade. A 'NdC', ainda em formas bastantes díspares das que hoje apresentam-se na literatura, iniciava a sua expansão e amadurecimento na área, tal qual o movimento Ciência-Tecnologia-e-Sociedade (CTS) (idem). Neste sentido, foi marcante a presença (ainda que de dias contados) de um 'objetivo de aprendizagem' de título ‘A Natureza da Ciência' no currículo galego-britânico em 1989 (idem).
} 
termo bastante popularizado a quase meio século em obras pioneiras de Apple (1971; 2004), e hoje lugar comum nas discussões críticas sobre currículo. As chamadas concepções tradicionais de currículo, que remontam às teorias desenvolvidas no início do século passado e às demandas da industrialização à época sobre os currículos escolares como as de John F. Bobbitt e Ralph Tyler (Lopes \& Macedo 2011, p.21) -, foram sendo duramente criticadas ou revisitadas ao longo dos últimos decênios, principalmente a partir dos anos 1960 e 1970. Resumidamente, importa enfatizar que a psicologia comportamentalista (behaviorista) e a administração taylorista - crescentes na sociedade estadunidense nos anos 1910 (idem) -, aliadas à ânsia por 'métodos mais eficientes' de construção de currículos, e principalmente à alegação da suposta 'neutralidade' destes processos, ocultavam, segundo Apple (1989), que estas concepções de currículo tinham suas origens "nas tentativas da indústria para controlar os trabalhadores e aumentar a produtividade, nos movimentos de eugenia popular e em grupos com interesses particulares de classe” (ibid., p.29).

Portanto, em absoluto, currículo não é apenas um documento neutro de natureza organizacional. Esta seria uma visão estreita de currículo, à qual pode associar visões também estreitas de escola e de processos de aprendizagem (Arroyo 1999). Uma concepção crítica do currículo abre as portas ao diálogo com professores de escolas e outros atores escolares, onde experiências pretensamente inovadoras ocorrem, sendo então fecunda para redefinir culturas, formular políticas e também inovar a prática escolar. Nesse sentido, como afirma Sacristán (2000, p.23), o “currículo é uma práxis antes que um objeto estático emanado de um modelo coerente de pensar a educação ou as aprendizagens necessárias das crianças e dos jovens”. No âmbito das teorias críticas de currículo, ainda segundo Sacristán, a concreticidade do conceito de currículo mostra-se na verdade tão presente quanto sua dimensão não-concreta, povoada de tramas de interesses políticos ideológicos, influências de políticas administrativas e burocráticas, assim como de seu caráter historicamente provisional e parcialmente relativo (idem) ${ }^{8}$.

\footnotetext{
${ }^{8}$ A proposta de Forquin (1992) é também um exemplo disto. Para Forquin, os ‘saberes escolares’ (um dos níveis de currículo), objetos de conhecimento engendrados pela própria escola, podem ser entendidos como suficientes na medida em que consideramos a insuficiência em abarca-los enquanto reflexos de 'saberes sábios' (outra faceta do currículo, associado ao conhecimento engendrado na esfera acadêmica). Forquin faz uma reinterpretação dos mecanismos da transposição didática, teoria associada aos trabalhos de Yves Chevallard, que culminam no que chama de 'saber a ser ensinado' - um dos últimos níveis do currículo -, adaptado dos saberes sábios de origem, que também não é concreto no sentido de que não ‘declarado’ em um documento curricular.
} 
É oportuno mencionar que concepções de currículo como assim descritas acima só se tornaram possíveis após as décadas de 60 e 70, palcos de diversas e importantes mobilizações sociais e políticas em diferentes contextos do mundo ocidental - algo que será novamente discutido em capítulos posteriores. É possível resgatar destas épocas as raízes do que chamamos hoje de teorias críticas de currículo, com o surgimento de teses de inspiração marxista sobre reprodução social escolar e estudos sobre "a atuação do sistema educativo na preparação dos sujeitos de cada classe social para assumir os papéis que lhe são destinados pelo sistema capitalista” (Lopes \& Macedo 2011, p.27). As chamadas teorias reprodutivistas - por vezes bastantes associadas à obra de Bourdieu e Passeron (1970), mas principalmente na obra de Althusser (1984) - procuraram mostrar, de forma geral, que a desigualdade cultural ocorre de forma semelhante à desigualdade econômica, porém não de forma necessariamente determinista. Estas, aliadas ao que ficou conhecido como Nova Sociologia da Educação (NSE) na década 1970 - como posteriormente será posteriormente discutido -, ajudaram a expandir o campo de estudo de currículo no sentido de "entender que o currículo não forma apenas os alunos, mas o próprio conhecimento, a partir do momento em que seleciona de forma interessada aquilo que é objeto de escolarização” (ibid., p.29). Com a acumulação de críticas principalmente provindas de teóricos ao status quo da 'ciência escolar', abriu-se as portas para várias abordagens de ensino alternativas, como os construtivismos, projetos de educação ambiental e ativismo científico-político, currículos sensíveis a questões de gênero, entre vários outros (Aikenhead 2006, p.5). O multiculturalismo educacional, ou a ideia de que diferentes formas de conhecimento merecem o mesmo status que o conhecimento escolar normal nas escolas, foi uma das correntes que se fortaleceram deste contexto. Com efeito, influenciadas por correntes pós-modernistas e pós-estruturalistas, tomaram lugar as teorias pós-críticas de currículo, nas quais o ponto vernal orbita a questão do currículo como construto cultural produtor de significados (ibid., p.93).

Ainda que o resgaste histórico acima esteja longe de ser exaustivo ou detalhado, os pontos elencados permitem afirmar com razoável segurança que teorias críticas e póscríticas de currículo, em oposição às teorias tradicionais, convergem pontualmente no sentido de desnaturalizarem o currículo de sua acepção comum como um mero documento de seleção neutro. Uma acepção crítica de currículo permite entender suas implicações educacionais, sociais, culturais e políticas, por outro lado, tal consciência é o primeiro passo em direção à proposição de ações concretas contra condições de opressão existentes na educação e sociedade. Como afirma Silva (2010, p.16), as teorias de 
currículo estão no centro de um território contestado - o interesse no currículo é, nesta perspectiva, um interesse político, e por isso a disputa. Ou ainda, nas palavras de Bernstein (2003 [1975]), “a batalha sobre o currículo é também um conflito entre diferentes concepções de ordem social e, por isso, é fundamentalmente moral” (ibid., p.81). E neste território contestado que ensejamos por (iniciar a) aproximar a HFC e NdC - ou, o conhecimento sobre a ciência -, pois, afinal, é preciso aproximá-las caso queiramos dar-lhes explicitamente um papel político mais substancial no EC.

Antes de concluir, é importante alertar que faremos o uso do termo 'conhecimento sobre a ciência' com mais frequência do que 'NdC' nos capítulos que se seguem. Antes que uma concordância plena com a proposta de Matthews (2012) - acerca do acrônimo CdC, 'características das ciências’ -, sem, no entanto, minimizar a importância desta manobra em apontar para fragilidades e limitações da VCNdC (Hodson 2014, p.947), visamos nos afastar da didatização tipo-tenets da NdC e nos aproximarmos do 'antigo' discurso da HFC no EC. 


\title{
2 Conhecimento sobre a ciência como uma contraideologia pelo conflito
}

\begin{abstract}
A idade ideal de teste em que as previsões altamente confiáveis poderiam ser feitas se tornou cada vez mais baixa. Em 2000, a idade confiável era nove; em 2015, a idade confiável era de quatro; Em 2020 era três (...). Era justo que [os estudantes] não fossem segregados até que seus Q.I.s fossem finalmente conhecidos. Mas quando estes puderam ser testados e identificados aos três anos, realmente não havia nenhum motivo para que crianças mais brilhantes estudassem nas mesmas escolas que outras, as quais inevitavelmente retardariam seus desenvolvimentos. Era muito mais sensato segregar estudantes extraordinários do resto em jardins de infância e escolas primárias, da mesma forma que jovens acima da média enviados a Oxford e Cambridge foram separados dos outros que conseguiram classificação apenas em universidades provinciais. (...) (Young 1958, p.179)
\end{abstract}

[Os pais] não precisam mais enviar seus filhos para uma escola primária comum, e se o Estado não fornece escolas especiais, eles já estão em alguns distritos estabelecendo escolas privadas, onde seus filhos se misturarão apenas com os da sua própria classe especial. Já não precisam mais olhar interrogativamente em seus berços, sem saber que tipo de educação seus filhos eventualmente terão. Seus filhos são, aos seus olhos, não apenas crianças, mas os governantes que nascem para um destino diferenciado (...). Uma vez que a necessidade de tratamento comum a todas as crianças até uma idade mínima foi questionada (...), alguns pais inteligentes foram estimulados a ir mais longe, se perguntando se a igualdade de oportunidades não é uma ideia completamente atrasada. (ibid., p.181)

A distopia do sociólogo britânico Michael Young ${ }^{9}$ acerca da ascensão da meritocracia como pedra angular da sociedade moderna e a hegemonia do privado, escrita há meio século, foi escrito num tom de pessimismo com as expectativas que se desenhavam no horizonte da época - é provável que não fosse de seu interesse ser preciso com as datas mencionadas. Sucede, no entanto, que sua crítica à 'eugenia escolar' - a qual tem como mecanismo concreto central os sistemas de avaliações padronizadas de larga escala (dos

\footnotetext{
${ }^{9}$ Não confundir com o sociólogo da educação também britânico Michael F. Young.
} 
quais se inferem os Q.I.s) - é, infelizmente, bastante atual. Muitas reformas educacionais e políticas públicas nos últimos anos (aqui e no exterior) - pode-se a elas adicionar o adjetivo 'neoliberais' - têm caminhado em direção a concretizar mais e mais tal quadro distópico. A ideologia meritocrática, que fundamenta o ranqueamento por testes, disfarça o agravamento das desigualdades de classe. Nessa lógica, os testes, suas estruturas e seus 'resultados', são legitimados por ideologias cientificista-positivistas, que garantem processos 'neutros' e 'objetivos'. Os documentos curriculares - se redigidos em uma ótica neoliberal-econômica sobre a educação -, ‘enquadram’ os conhecimentos para serem 'testáveis' - que então se tornam 'cinza' (Robilotta 1989), sem conflitos, 'consensuais'. Os estudantes e professores, estrangulados por sua vez entre tais currículos e a pressão de tais testes, se desdobram como podem para, no fim, serem classificados por 'mérito individual' entre 'vencedores’ e 'perdedores' - não importando as condições estruturais, materiais, econômicas e culturais que determinam tão mais os resultados quando o desempenho individual. Como pano de fundo disto está o que diferentes autores chamam de mercantilização da educação - umas das engrenagens centrais do capitalismo tardio neoliberalista -, fenômeno social muito bem resumido por Sader (apud Mészáros 2006, p. 16)

\footnotetext{
No reino do capital, a educação é, ela mesma, uma mercadoria. Daí a crise do sistema público de ensino, pressionado pelas demandas do capital e pelo esmagamento dos cortes de recursos dos orçamentos públicos. Talvez nada exemplifique melhor o universo instaurado pelo neoliberalismo, em que "tudo se vende, tudo se compra", "tudo tem preço", do que a mercantilização da educação. Uma sociedade que impede a emancipação só pode transformar os espaços educacionais em shopping centers, funcionais à sua lógica do consumo e do lucro.
}

Esta e outras não são engrenagens fáceis de se quebrar. A tarefa de combater concretamente as ideologias mencionadas, as reformas e políticas públicas educacionais balizadas por setores dominantes da sociedade, transcende as possibilidades de um texto acadêmico. Contudo, acreditamos ser possível propiciar uma contribuição teórica a esta urgente tarefa, mostrando como um determinado tipo de conhecimento (o conhecimento sobre a ciência) está sendo ‘enquadrado’ para ser eventualmente incluído em testes padronizados de ranqueamento. Em resumo, nosso objetivo neste capítulo é, uma vez esclarecido e justificado que (meta) conhecimento é este - a saber, a VCNdC na forma de tenets -, apresentar um argumento em defesa de um conhecimento sobre a ciência 
enquanto uma contraideologia pelo conflito. Uma contraideologia do conflito contra uma ideologia que mantém uma visão sem conflitos tanto de sociedade como de ciência. Deixando de assim conceber o conhecimento sobre a ciência, emergem condicionantes de forma e conteúdo da NdC, e evidencia-se um papel político da HC no EC.

O argumento a ser apresentado é fortemente inspirado na obra de Michael Apple, em especial em seu escrutínio sobre o currículo oculto em Ideology and Curriculum publicado em 1979. O seu conceito de conflito - rediscutido e ampliado por outros autores críticos como Wayne Au (2009, 2011, 2013) e João Paraskeva (2011) - tem um papel central para nós. O seu conceito de ideologia, o qual em momentos de sua obra era bastante próximo àquele de Althusser (1984), também nos é caro, ainda que tomemos mais oportunamente a abordagem de Mészáros (2005). A obra de Apple, que é muito timidamente presente na literatura especializada de pesquisa em EC (em especial na literatura brasileira), pode ser caracterizada como a de um teórico crítico neomarxista da sociologia da educação. Como diversos outros autores, estudiosos da obra do curriculistas identificam fases de pensamento (pelo menos três), decorrentes de uma série de fatores e acontecimentos que balizaram sua carreira. As raízes de suas obras - ou, de certa forma, também da tradição crítica de currículo neomarxista - remontam à movimentada década de 60 do século passado. Como resume Silva (2010, p.26):

\footnotetext{
Os movimentos de independência das antigas colónias europeias; os protestos estudantis na França e em vários outros países; a continuação do movimento dos direitos civis nos Estados Unidos; os protestos contra a guerra do Vietnam; os movimentos de contracultura; o movimento feminista; a libertação sexual; as lutas contra a ditadura militar no Brasil: são apenas alguns dos importantes movimentos sociais e culturais que caracterizaram os anos 60. Não por coincidência foi também nessa década que surgiram livros, ensaios, teorizações que punham em xeque o pensamento e a estrutura educacional tradicionais.
}

Ao longo dos últimos quarenta anos as obras de Apple sempre tenderam a orbitar algumas características centrais - entre elas, a ausência de uma definição rígida de currículo, a problemática do conhecimento e a postura crítica frente a tendências conservadoras e neoconservadoras (Paraskeva 2001). Segundo Paraskeva (idem) é possível identificar a raiz do pensamento curricular progressista de Apple já em autores do fim do século XIX e início do XX - entre eles John Dewey, Dwayne Huebner e James Macdonald. O conceito de conflito e currículo oculto é apresentado em um artigo publicado oito anos antes de Ideology and Curriculum (e que irá lhe compor uma parte 
fundamental), de título The hidden curriculum and the nature of conflict (Apple 1971), aos ecos dos movimentos de contracultura, dos movimentos de direitos civis dos negros nos Estados Unidos e do macarthismo. Nesse contexto, as doutrinas comportamentalistas e eficientistas já eram bastante criticadas (Paraskeva 2001), e, paralelamente, torna-se cada vez mais disponível a emergência de novas sociologias da educação e visões curriculares com forte aporte marxista.

Com efeito, o marxismo - como observado por Apple e outros autores de inspiração marxista -, ainda que passando por várias metamorfoses, dificilmente deixou de ser um dos tópicos centrais em educação no último século. Seu legado nas ciências humanas e sociais é reconhecidamente inegável (ver Bucher 2015; Sheehan 1993). Nas palavras de Hall (2000, p.24), ele é ao mesmo tempo constantemente ‘transcendido’ e 'preservado’. Na educação, o marxismo é igualmente importante, em especial, nos campos da pedagogia e currículo - muito embora gere tensões de tempos em tempos, como ilustram o fenômeno do 'antiesquerdismo' vociferado pelo movimento EsP atualmente no contexto brasileiro. Foi declarado 'morto' no início da década de 1990, diretamente associado ao fim da União Soviética e à queda do muro de Berlim, ante a 'vitória' do capitalismo - ainda que, como afirma Gamble (1999, p.128), não raro os movimentos de esquerda no mundo viam a União Soviética não como 'antro do marxismo', mas como oposição geopolítica ao capitalismo. Isto, por exemplo, refletiu-se de forma particular na alteração do enfoque curricular em diversos países que estavam sobre a 'tutela soviética', como Moçambique, que passou de um currículo de alto teor socialista para um currículo neoliberal (Zavale, 2013).

Muito antes do fim da União Soviética, o marxismo ortodoxo já havia sido declarado algo como ‘ultrapassado’ nos eventos de maio de 1968 na França - que teve como um dos slogans a frase 'Nem Washington, nem Moscou' (ibid., p.127) -, uma das raízes daquilo que mais tarde seria chamado de pós-marxismo. Este acontecimento, por sua vez, certamente influenciou um dos ápices históricos de trabalhos teóricos críticos na educação, sendo exemplos disto publicação do livro La Reproduction de Pierre Bourdieu e Jean-Claude Passeron em 1970, no mesmo ano a publicação do ensaio Idéologie et Appareils Idéologiques d'État por Althusser, e a publicação em ano seguinte do livro Knowledge and Control editado por Michael Young, inaugurando a NSE. Também nesta 
época, Paulo Freire - exilado no Chile - escreve Pedagogia do Oprimido em $1968^{10}$, publicado nos Estados Unidos em 1970 e no Brasil somente quatro anos mais tarde autor que Apple (1999) explicitamente classifica dentro da tradição crítica, e cuja obra foi de influência notável (inclusive, para ele próprio).

Com efeito, na filosofia, a teoria crítica - que Bucher (2015, p.273) localiza na chamada segunda escola de Frankfurt - buscava uma nova compreensão do potencial emancipatório da Modernidade - isto é, no espírito iluminista -, rejeitando movimentos anti-iluministas (ou, a perspectiva catastrófica de uma ‘tragédia do Iluminismo’) e propondo a reanálise crítica da razão (racionalidade moderna), da relação sujeito-objeto, assim como da teleologia marxista e o ideal revolucionário (ibid., p.268-70). Um de seus principais expoentes, Habermas, se opôs ao romantismo anticapitalista irracionalista característico de alguns membros da primeira escola de Frankfurt, em especial a Adorno e Horkheimer, para quem a racionalidade do Iluminismo desemboca necessariamente num neopositivismo (idem). Tal tipo de romantismo encontraria ressonância anos depois com os ‘novos filósofos franceses’ pós-modernistas.

Comentadores da obra de Apple - e o próprio autor - concordam que sua abordagem em diferentes fases distingue-se da de um marxismo ortodoxo. De fato, afirmou em diferentes ocasiões que não se é para ter ‘medo de heresia’ (Gandin \& Lima 2016), numa alusão de não se prender à ortodoxia. Seu leque de influências no âmbito do marxismo, além obviamente do filósofo alemão, contempla nomes como Raymond Williams e Antonio Gramsci (de quem apropriou o conceito de hegemonia ideológica). Na teoria crítica, Habermas e Marcuse foram certamente influentes para sua formação intelectual (Paraskeva 2001). Como resumem Gandin e Lima (2016, p.661):

Apple filia-se ao campo do neomarxismo, que busca analisar como cultura, ideologia, hegemonia e autonomia relativa se relacionam à educação. Os estudos neomarxistas estão relacionados (...) [às] contribuições de Antonio Gramsci. Este autor, segundo o próprio Apple, trouxe importantes contribuições para esta corrente teórica. A incorporação desses conceitos à teoria neomarxista permitiu o reconhecimento de que aspectos relacionados com sociedade, hegemonia, política e cultura não estão completamente relacionados às questões econômicas. Além disso, os neomarxistas defendem

${ }^{10}$ Do ponto de vista político este ano também é emblemático para o Brasil, em especial pela intensificação dos movimentos de resistência à ditadura militar concomitante à intensificação da repressão estatal e perseguição política - bastando, para isso, lembrar-se da homologação do Ato Institucional número 5, assinado em dezembro (cujos efeitos, na verdade, já se faziam sentir antes mesmo da emissão por Costa e Silva), fazendo 1968 entrar para a história brasileira como o “ano que não terminou” (ver Ventura 1988). 
que a cultura e a hegemonia por si só são importantes áreas para a análise crítica, apresentando contradições significativas para o entendimento dos processos sociais. Apple aponta que o uso do conceito de hegemonia em pesquisas de políticas educacionais ajuda a entender por que alguns segmentos racialmente oprimidos nos Estados Unidos apoiaram movimentos de privatização da educação - o que, em última instância, ampliou as desigualdades existentes. Nesse caso, apenas a categoria de classe não explica essas motivações, o que reforça a necessidade de operar com categorias de âmbito cultural, como raça, por exemplo.

Uma questão específica da citação acima concorda com uma análise mais filosoficamente minuciosa da obra de Apple, que conclui que seu materialismo não é o mesmo materialismo de Marx, tanto por questões de localização histórica como de fundamentos, uma vez que em Apple ele não compõe a centralidade das relações de classe (Banfield, 2015, p.145). Ademais, em concordância à falta de medo de ser 'herético', Apple se apropriou de algumas pautas pós-modernas - ainda que fosse bastante crítico ao ‘esoterismo pós-modernista’ (Carlson \& Apple, 2003, p.14), às tendências de reduzir tudo a 'textos' (Apple, 1993). Apple também se afastou um pouco de importantes conceitos marxinianos como o de classe (Au \& Apple, 2009, p.92)- se aproximando, em especial, de questões ligadas a identidade, gênero e raça, o que gerou críticas por outros autores marxistas devido a seu 'antinaturalismo' e distanciamento de uma postura realista marxiniana (Banfield, 2015, p.116; Skordoulis, 2009) ${ }^{11}$.

Em absoluto, as considerações de Apple sobre o positivismo na educação científica (embora relativamente antigas) serão úteis para explicitarmos nas seções seguintes as conexões entre os processos de mercantilização da educação, políticas de avaliações padronizadas, ideologia e a abordagem em tenets da $\mathrm{NdC}^{12}$. Importa salientar que, sendo vastíssima, não faremos justiça a todos os detalhes da obra de Apple - a qual vai a diferentes direções enfrentando problemas educacionais e sociais estruturais urgentes, envolvendo, por exemplo, questões raciais e de identidade. Embora as realidades brasileira e estadunidense tenham semelhanças - principalmente no que se refere ao que é

\footnotetext{
${ }^{11}$ Algumas questões referentes à postura filosófica de Apple e suas tensões com posições realistas serão comentadas rapidamente no último capítulo.

${ }^{12}$ Como já comentado, a obra de Apple estende-se muito além de Ideology and Curriculum, por meio dos inúmeros livros e artigos publicados pelo autor. A questão racial e de identidades, muito importante para Apple, será comentada sem maiores aprofundamentos em capítulo posterior. Não se configurando enquanto uma crítica propriamente ao trabalho de Apple, traremos considerações sobre o relativismo epistêmico presente em algumas abordagens pós-críticas de currículo. Apple, em diversas ocasiões, também expressou suas reservas quanto ao relativismo pós-moderno (ver Carlson \& Apple 2013).
} 
oferecido ('destinado') às camadas mais exploradas da sociedade -, o que significa que as contribuições de Apple certamente têm muito a oferecer (e tem oferecido) aos problemas locais, nos limitamos neste trabalho a uma apropriação reduzida delas. Há pelo menos duas justificativas para esta nossa atitude. Primeiro, esperamos que com o tempo mais trabalhos surjam estabelecendo pontes entre estudos sobre HFC e NdC no EC e teorias de currículo. Em segundo lugar, acreditamos que mesmo tal apropriação limitada permite insights que esclareçam dimensões da questão da HFC e NdC no EC não suficientemente discutidas em trabalhos na literatura especializada. Ao fim do capítulo, apresentamos nosso primeiro argumento desta tese, cujas bases conceituais (e, de certa forma, também empíricas) serão explicitadas nas seções a seguir.

\subsection{Capitalismo tardio, reformas educacionais e mercantilização da educação}

A mercantilização da educação é reconhecida - em especial por curriculistas e teóricos críticos - como um dos principais problemas atuais da educação, que tem se agravado pelo fato de reformas educacionais nos últimos vinte anos estarem caminhando inexoravelmente nesta direção. A recente reforma do ensino médio no Brasil, que resgatou um anseio de 'modernização' da educação (Castro 2011, p.3), celebrada pelas alas conservadoras no congresso brasileiro - para mais, supostamente ‘aprovada' por uma alta cifra percentual da população brasileira ${ }^{13}$-, é um dos exemplos recentes e preocupantes no contexto brasileiro.

\footnotetext{
${ }^{13}$ Referimo-nos à pesquisa encomendada pelo MEC ao IBOPE, em 2016, referente à aprovação popular da proposta de reforma do ensino médio (ver http://www.brasil.gov.br/educacao/2016/11/mais-de70-dos-brasileiros-aprovam-mudancas-no-ensino-medio, acesso janeiro de 2017), difundido inicialmente pelo portal G1 (ver https://g1.globo.com/educacao/noticia/72-aprovam-proposta-de-reforma-do-ensinomedio-diz-pesquisa-ibope.ghtml, acesso janeiro de 2017). A pergunta da pesquisa (por sinal, extremamente tendenciosa) foi ' $O$ senhor é a favor ou contra a reformulação do ensino médio que, em linhas gerais, propõe ampliação do número de escolas de ensino médio em tempo integral, permite que o aluno escolha entre o ensino regular e o profissionalizante, define as matérias que são obrigatórias, entre outras ações?’. Ela foi realizada entre 30 de outubro e 6 de novembro de 2016, como 1200 pessoas. Em diversas plataformas de comunicação digitais, nem sempre é enfatizado que a maior parcela de aprovação à reforma foi com entrevistados maiores de 55 anos (os quais apresentaram índice de aprovação de 78\%), e que a maior parcela de reprovação foram justamente os jovens entre 16 e 24 anos (com índice de 35\%) (ver https://istoe.com.br/ibope-72-aprovam-reforma-do-ensino-medio-e-59-sao-a-favor-da-pec-do-teto/, acesso julho de 2017). A porcentagem de 72\% de 'aprovação' é curiosamente proporcional, quase na mesma medida, à reprovação da reforma em enquete aberta (consulta pública) feita no site do senado federal (ver https://www.congressonacional.leg.br/materias/medidas-provisorias/-/mpv/126992, acesso março de 2018).
} 
Não é fato desconhecido que a mencionada proposta de reforma foi entendida como um grande retrocesso por autores críticos de veia progressista (ver Ferreira 2017) - e também por uma parcela significativa de estudantes secundaristas que ocuparam diversas escolas no fim de 2016 (Hebmüller 2016). Em especial, o retrocesso se caracteriza não apenas pela medida provisória 746/2016 em si, mas pelo aspecto estrutural a que está associada, que envolve também as recentes propostas de reformas da previdência e leis trabalhistas. Tal retrocesso foi visível, por sinal, nas discussões acerca da BNCC entre suas versões consecutivas, que progressivamente foram ,segundo Macedo (2017, p.513), se afastando do ideal de pensamento crítico chegando a uma retórica de explicitação de direitos de aprendizagem. Todavia, é sensato entender que esta teia estrutural de retrocessos vem antes mesmo do golpe parlamentar de 2016, passando pelas políticas econômicas e educacionais dos governos presidenciais do Partido dos Trabalhadores e do Partido da Social Democracia Brasileira - ainda, que este fenômeno não seja exclusivamente brasileiro. É completamente inviável exaurir esta complexa questão aqui contudo, será oportuno apontar para algumas de suas características centrais.

Apple (2016) identifica este fenômeno, especificamente no contexto estadunidense, com a emergência do neoliberalismo - ou melhor, com as reformas de cunho neoliberal e com a ascensão do que chama de bloco conservador de modernização nos anos 1990. Este bloco, composto pelo que Apple chama de neoconservadores ${ }^{14}$, conservadores religiosos, a nova classe média e ‘empreendedores', compõe o que chama 'nova direita' estadunidense, e tem tido uma enorme influência na educação (ibid., p.2) - nota-se a grande semelhança com o caso brasileiro ${ }^{15}$. Ainda, suportando esta aliança conservadora está o que Apple chama de 'populistas autoritários', membros da classe trabalhadora “preocupados com a sua sobrevivência econômica e que, portanto, em seus cotidianos, lutam, defendendo valores morais estritos, para que essa aliança sobreviva” (Gandin \& Lima 2016, p.656). Já as reformas educacionais neoliberais caracterizam-se, de forma

\footnotetext{
${ }^{14}$ Diferentes autores utilizam diferentes designações para o ‘neoconservadorismo’ (ver Apple 2016; Bernstein 2000b; Young 2016a), sendo mais significantes as convergências das conceitualizações do que as divergências. Quando for necessário, salientaremos diferenças conceituais entre as abordagens de diferentes autores.

${ }^{15}$ Como exemplo, vale mencionar alguns dos convidados a uma das audiências públicas realizadas no fim de 2016 sobre a reforma educacional brasileira: Denis Mizne (diretor-executivo da Fundação Lemann), Ricardo Henriques (superintendente do Instituto Unibanco), Priscila Fonseca da Cruz (presidente do 'Todos pela educação') e David Saad (diretor do Instituto Natura). A ala religiosa conservadora mostrou as caras nos projetos inspirados no movimento EsP que surgiram nas câmaras municipais em todo o país, com um dos principais argumentos o de 'proteger' as crenças religiosas dos estudantes enquanto audiência cativa ainda, celebrou a autorização do STF do ensino religioso confessional nas escolas públicas em outubro de 2017.
} 
resumida, pelos processos de privatização e mercantilização da educação - alimentadas entre outras coisas por uma combinação aparentemente contraditória entre uma retórica de 'Estado mínimo’ e políticas bastante centralizadoras (Apple 2011, p.22). Estes são duas particulares engrenagens - que, entre diversas consequências, engordam o espaço privado dos interesses de mercado e encolhem o espaço público dos direitos (Chauí 2017, p.56) - daquilo que diferentes autores classificam de era do capitalismo tardio (Jameson 1996).

Aparentemente nunca houve na história do Brasil uma invasão tão profunda no capital privado na educação (Leher \& Vittoria 2016, p.107). Isto por si só torna a questão da mercantilização extremamente urgente e, ao mesmo tempo, bastante complexa. Todavia, ela foi bem resumida no discurso síntese do primeiro Fórum Mundial de Educação, realizado em Porto Alegre em 2001, por Bernard Charlot (2005). Após resgatar um princípio de base, pautado na "educação pública para todos como direito social $e$ inalienável, educação garantida e financiada pelo Estado, jamais reduzida à condição de mercadoria e serviço” (ibid., p.142), Charlot alertou à lógica instaurada pela globalização neoliberal, a qual há muito já era predominante nas políticas internacionais sobre educação. Entre as características dessa lógica, tem-se, segundo Charlot, que “a educação deve ser pensada e organizada, prioritariamente, em uma lógica econômica e como preparação ao mercado de trabalho" sendo preciso então "preparar trabalhadores 'empregáveis', 'flexíveis', 'adaptáveis' e 'competitivos”, e que “os investimentos educativos e os currículos escolares devem ser pensados em termos de adequação às demandas do mercado" (idem). Ela se faz presente, segundo Charlot, em todos os níveis, desde o ensino básico até o superior e inclusive no nível da pesquisa.

Tais objetivos de formação escolar para o mercado de trabalho são evidentes em comunicações feitas pelo Grupo Banco Mundial - uma das maiores agências de influência político-econômica e de alto poder coercitivo, principalmente sobre países em desenvolvimento -, seja em livros publicados pela instituição como também no conteúdo de periódicos mantidos por ele, como o Finance \& Development. Dois exemplos de artigos deste são oportunos. Riad (2017) destaca vários dos objetivos comentados por Charlot, e sugere que o papel central da educação é unicamente preparar os jovens para empregos que ainda não existem. Jimenez, King e Tan (2012) afirmam que não se pode 'perder tempo' na escola não aprendendo habilidades para o trabalho ('job-relevant skills'), tais como (ibid., p.13) 'resolução de problemas', 'criatividade', 'trabalho em equipe’, 'habilidade de comunicar-se’, 'pré-disposição a aceitar responsabilidades', 
'pensamento crítico', 'iniciativa', 'empreendedorismo’ e 'pontualidade' - os autores chegam a naturalizar algo como um 'pensamento empreendedor' como resultado de uma etapa de desenvolvimento neurológico pós-puberdade.

Como afirmam Júnior e Maués (2014, p.1147), nestes e em outros documentos do Banco Mundial, é bastante visível o olhar economicista sobre a função da educação atender às demandas do capitalismo (tardio). É curioso notar também como não raro tais discursos vêm carregados de certo 'altruísmo neoliberal', defendendo combater a desigualdade, proporcionar igualdade de oportunidades e 'salvar os pobres' (Accioly, Gawryszewski \& Nascimento 2016, p.33). Em outro artigo da Finance \& Development, Lustig (2015, p.16), a propósito, afirma que é 'a coisa certa a se fazer' melhorar a condição dos mais pobres, "mesmo em tempos de dificuldades fiscais” (grifo nosso). Ainda neste olhar economicista, o papel do governo seria então o de "transformar gastos na educação em resultados educacionais” (Banco Mundial apud Júnior \& Maués 2014, p. 1147, grifo nosso).

Autores críticos sugerem que estes traços remontam ao que parece ter sido, ainda que de forma aproximada, um dos princípios das políticas educacionais brasileiras nos últimos vinte anos - é oportuno citar o comentário de Júnior e Maués (ibid., p.1139) acerca do alinhamento entre MEC e o Banco Mundial no governo Fernando Henrique Cardoso:

\footnotetext{
O alinhamento estratégico entre o Ministério da Educação do Brasil (MEC) e o Banco Mundial era tamanho, nesse período, que os principais quadros responsáveis pelo governo brasileiro em matéria de educação, a começar pelo ministro, já haviam feito parte do staff como diretores ou como consultores das agências que compõem o Grupo Banco Mundial e outras agências multilaterais. É o caso, por exemplo, de Paulo Renato Souza (ministro da Educação durante os dois mandatos de Fernando Henrique Cardoso), Guiomar Nano de Mello (membro do Conselho Nacional de Educação a partir de 1997 até o fim do mandato de FHC) e Cláudia Costin (ex-ministra da Administração), entre outros (...).
}

A perspectiva economicista de educação e os interesses mercadológicos não diminuíram nos governos de Lula da Silva e Dilma Rousseff. Leher e Vittoria (2016, p.118) comentam alguns pontos que levaram à continuidade nas políticas educacionais entre elas a iniciativa do 'Todos pela Educação' entre outras, entendidas pelos autores como respostas às demandas de setores mercantilistas no ensino superior, tais como Programa Universidade para Todos (ProUni) e o Programa de Financiamento Estudantil 
(FIES). Outro ponto foi a aprovação do PNE 2014-2024, no sentido de frustrar anos de lutas de movimentos sociais e estudantis em defesa da implementação imediata de $10 \%$ PIB em educação (idem) ${ }^{16}$. Como endossam os autores, o plano abriu as portas a uma intensificação de processos já antigos de mercantilização da educação e também ao surgimento de novos - tal como o sistema de vouchers no ensino básico, no qual fundos públicos são repassados a pais que tem o 'direito de escolha' sobre qual escola particular matricular seus filhos. 'Pagar por aquilo que se tem direito' (neste caso, educação pública gratuita de qualidade) - esta é uma das contradições que estão na essência da mercantilização da educação (Karpov 2013, p.31).

O sistema de vouchers é apenas uma das consequências possíveis da implantação da lógica de mercado na educação. Freias (2016, p.141) também cita a terceirização da gestão a uma organização privada ${ }^{17}$, e lembra que tais políticas educacionais, impulsionadas por 'reformadores empresariais', são fundadas na crença da melhora da educação pela lógica de competição mercadológica e nas ideias de meritocracia e responsabilização ${ }^{18}$ (idem). A presença do empresariado nas reformas educacionais é defendida por suas “ideias modernizantes e técnicas eficazes” (Castro 2011, p.10) e pela gestão do tipo empresarial, em contraposição à suposta ineficiência do setor público. Tal defesa é a última etapa da conhecida estratégia neoliberal - primeiro, sucatear e 'forçar à ineficiência’ dos setores públicos, que vão recebendo cada vez menos recursos entrando numa espiral negativa (Freitas 2016, p.142), depois, usar o sucateamento e a ineficiência para justificar a ‘necessidade’ da lógica mercadológica (Hall 2011, p.19).

O impulso de colocar tudo a serviço do capital, de transformar tudo em mercadoria, num ambiente onde a produção de consumidores pode ser até mais necessária que a de produtos (Carlson \& Apple 2003, p.38), também transforma o humano em 'ser consumidor' - um ser que não se associa a um cidadão que possa precisar ou contar com os serviços públicos (Hall 2011, p.21). Também nesta esteira, universidades acabam por virar organizações (Chaui, 2016/1979; 2003; 2017), conhecimentos acabam por virar

\footnotetext{
${ }^{16}$ Os autores também comentam do desacordo do governo de Lula da Silva com a CNTE (Confederação Nacional dos Trabalhadores em Educação), a UNE (União Nacional dos Estudantes) e a CONTEE (Confederação Nacional dos Trabalhadores dos Estabelecimentos de Ensino), em especial devido a políticas como o PROUNI que permitiam a transferência de fundos públicos a corporações (Leher \& Vittoria 2016, p.116).

${ }^{17}$ Exemplos disto no ensino básico são numerosos. Um exemplo bastante recente no contexto do ensino superior público é o caso (não resolvido) envolvendo a associação Comunitas e McKinsey \& Company e a denúncia de projetos de ‘captação de recursos' e 'gestão adminitrativa' na Universidade de São Paulo (Peres \& Neto 2017).

${ }^{18}$ Retomaremos esta questão, envolvendo a ideologia meritocrática, na seção 2.3.
} 
dinheiro-capital (Bernstein 2000a, p.86) e educação se torna comódite - adjacentemente, a garantia de democracia se torna, antes de tudo, 'poder de escolha do consumidor' (Apple 1999, p.10) -, como exemplifica Apple (2005, p.46):

\begin{abstract}
Por exemplo, para se comercializar algo como a educação, primeiro ela deve ser transformada em comódite, um "produto". O produto, então, fica lá para atender a diversos fins. Assim, em vez de a escola ter como objetivo último a criação da cidadania democrática e crítica (...), todo o processo pode pouco a pouco, visar a geração de lucro para os acionistas, ou virar um lugar, cujo propósito escuso seja o de documentar a eficiência de novas e autorizadas formas de gerenciamento, dentro do Estado reconstituído (...).
\end{abstract}

Apple (1999 p.12) alerta que até mesmo a audiência cativa dos estudantes pode ser posta a venda, tal qual o caso do Channel One estadunidense ${ }^{19}$. Ou seja, os estudantes, em especial os das classes menos favorecidas, são vistos não só como futuros trabalhadores (potencialmente exploráveis e descartáveis), mas também como consumidores (no caso analisado por Apple, por meio das propagandas nas mídias educativas) e moedas de troca garantidas pela obrigatoriedade da educação (idem). Paralelamente, a expansão do setor privado traduzido multiplicação de escolas particulares e a intensificação da mercantilização da educação levou à 'operarização' do professorado, de quem corporações educacionais extraem mais-valia, numa 'eficiente' combinação de pagamento por hora, falta de tempo (que dificulta desenvolvimento de carreira e até mesmo preparação de aulas, devido a múltiplos locais de trabalho e/ou insuficiência de renda), desvalorização social da carreira e salas em geral sempre lotadas de colégios particulares ${ }^{20}$ (Leher 2016, p.xii). Entretanto, não é somente a educação básica que está sujeita à invasão do capital - também estão as universidades e os próprios conhecimentos, como comentaremos a seguir de forma não exaustiva.

Segundo Oliveira (2013, p.2464), há pelo menos três maneiras pela qual a ciência pode ser mercantilizada: no direcionamento de pesquisas científicas pelo mercado; na introdução de 'metodologias empresarias', e; pela mercantilização dos bens intelectuais, que se reflete na concepção mercantil de dispositivos legais específicos como os direitos

\footnotetext{
${ }^{19}$ Channel One News é uma emissora e provedora digital estadunidense, fundada no início dos anos 1990. Oferece hoje conteúdo educacional por serviços do tipo broadcasting, e é conhecido por sua alta carga de merchandising comercial na programação diária.

${ }^{20}$ Embora Leher (2016) se refira especialmente ao ensino básico, fenômeno similar tem ocorrido no ensino superior público. A precarização (exógena e forçada) de carreiras de docentes tem sido cada vez mais intensa, tanto em universidades federais e estaduais - como relata Pomar (2015) no caso específico da Universidade de São Paulo com regimes de parciais de trabalho, remunerações baixas e alta carga didática.
} 
de propriedade, patentes, direitos autorais, e outros. A mercantilização do primeiro tipo se caracterizou historicamente pela emergência do conceito de 'inovação' dentro do discurso científico (ibid., p.2469). Simultaneamente, a ‘ineficiência’ do financiamento público justificou a entrada do setor privado, todavia, este não arca com os custos da ciência - de forma que, em geral, o Estado é o maior financiador da ciência ${ }^{21}$ (ibid., p.2472)-, e, por outro lado, influencia no direcionamento de pesquisas. Uma evidência pontual disto é esclarecida por Ball (2004, p.19):

Em fevereiro de 2003 o New England Journal of Medicine [NEJM] pediu desculpas publicamente por falhas em suas páginas nos anos que passaram. Encontrou-se que em quase a metade de 40 artigos sobre terapia química que foram publicados desde 1997 (artigos os quais são citados como constituindo resultados objetivos em acordo à reputação do jornal) as 'análises das substâncias eram feitas por autores com ligações financeiras com os produtores daquelas’ (...). O status e a independência do NEJM é usado por produtores como uma forma de endossar a eficácia de seus produtos.

Associadamente, o 'refinamento' do conceito de aplicação (com lemas do tipo 'aplicações não devem ser só úteis, mas rentáveis’) acabou por deixar em segundo plano o que Oliveira (2005) chamou de ‘valor intrínseco do conhecimento' (idem). Naturalmente, isto tem consequências graves. As ciências básicas, que em geral são 'demoradas' - algo que é importantíssimo à produção de conhecimento de um ponto de vista crítico (Karpov 2013, p.13) - e não gozam do status de 'inovadoras', ficam diretamente ameaçadas (Oliveira 2013, p.2474) - ou, condenadas à espiral negativa (Freitas 2016, p.142). As ciências com interfaces grandes com setores industriais, farmacêuticos e outros, ficam reféns da lógica do capital neoliberal, do que é 'lucrativo' e do que é 'útil' (ao mercado), como ilustrou o exemplo de Ball. Por fim, mas não menos importante, Oliveira (2013, p.2477) nos alerta que a mercantilização da ciência e o 'inovacionismo' erodem a objetividade científica, por afetarem a qualidade (e a natureza) das pesquisas e a confiança social e entre pares científicos sobre elas. Mirowski (apud Weinstein 2017, p.830) fornece outros três exemplos de como o neoliberalismo afeta a ciência:

\footnotetext{
${ }^{21}$ Oliveria (2013) afirma isto especificamente para o contexto estadunidense, porém, o mesmo vale para o caso brasileiro.
} 
Em primeiro lugar, [o neoliberalismo] envolve a ciência através de um novo regime de direitos de propriedade intelectual que limita as operações interinstitucionais - transformando universidades e seus laboratórios em instituições concorrentes. Em segundo lugar, o foco em pesquisas de rápido retorno para o mercado tomou considerável espaço de grande parte da literatura de pesquisa que se concentra em resultados inesperados. Finalmente, como resultado da lógica de Hayek, de que o único valor real é o valor de mercado, a ciência encontra-se como uma concorrente em desvantagem da junk science [ciência lixo] - pesquisas fraudulentas como aquelas de indústrias de tabacos que concluem que não existem efeitos negativos para a saúde decorrentes dos cigarros de tabaco -, a qual tem valor de mercado, uma vez que promove o lucro corporativo.

Não é surpresa que a mercantilização da educação também afeta as relações pessoais entre pesquisadores e membros da academia. Diferentes autores apontam que ela está intimamente relacionada com o produtivismo-competitivismo acadêmico exacerbado que se disseminou nos últimos tempos - os quais estimulam uma lógica de avaliação de produtividade que, por sua vez, implica numa relação mercantil dos pesquisadores com as universidades. Esse produtivismo pode ser entendido como um trabalho-pesquisa alienado (no sentido marxiniano) (Oliveira 2005) - e mostra, como discutiremos a seguir, como também as universidades públicas, em grande parte, estão se tornando cada vez mais reféns da lógica neoliberal.

Um dos principais sintomas deste decurso é o que Chauí (2003) concebe como visão 'operacional-organizacional de universidade', sustentada pelo que chama de ideologia neoliberal $^{22}$. Enquanto organização, a universidade rende-se à fragmentação competitiva e às exigências de mercado, produzindo “conhecimento destinado à apropriação privada” (ibid., p.8), e supõe-se que deve ser dirigida “segunda as mesmas normas e os mesmos critérios com que se administra uma montadora de automóveis ou uma rede de supermercados” (Chaui 2017, p.59). Um fato alarmante é de que intensificação desta tecnocracia universitária foi concomitante à redução de investimentos da União no ensino superior como percentual do PIB (Júnior \& Maués 2014, p.1144) ${ }^{23}$. A própria noção de pesquisa é mercantilizada:

\footnotetext{
${ }^{22}$ Esta questão será retomada na seção 2.3.

${ }^{23}$ Os autores citam a redução 0,97\% para 0,62\% entre os anos de 1989 e 2006. Fontes Banco Central do Brasil e IPEA.
} 
Numa organização, uma "pesquisa" é uma estratégia de intervenção e de controle de meios ou instrumentos para a consecução de um objetivo delimitado. Em outras palavras, uma "pesquisa" é um survey de problemas, dificuldades e obstáculos para a realização do objetivo, e um cálculo de meios para soluções parciais e locais de problemas e obstáculos locais. Pesquisa, ali, não é conhecimento de alguma coisa, mas posse de instrumento para intervir e controlar alguma coisa. Por isso mesmo, numa organização não há tempo para a reflexão, a crítica, o exame de conhecimentos instituídos, sua mudança ou sua superação. (ibid., p.60)

Dentro desta visão de mundo, é 'óbvio' que a universidade 'deve' ser avaliada basicamente em termos de ‘custo-benefício’ e 'eficiência’ (quanto foi ‘produzido’ em quanto tempo) - e isto se ramifica até os docentes, técnicos e estudantes. Isto suscita alguns fenômenos conhecidos dentro da academia - 'carteis' de grupos de pesquisa se citando para aumentar o índice $h$, periódicos ‘sugerem' citações de artigos de edições anteriores, publicações de livros didáticos de centenas de páginas 'valem’ menos que artigos de pouquíssimas, a docência universitária é terceirizada para (além de economizar os 'gastos’ com educação) dar tempo à 'pesquisa', sem contar o incentivo tácito a plágios, publicações repetidas, artigos 'envernizados’ ou irrelevantes (Halffman \& Radder 2017). Logo, "se por pesquisa entendermos uma ação civilizatória contra a barbárie social e política, então, é evidente que não há pesquisa numa universidade operacional” (Chaui 2017, p.61) o que, além de alargar mais a distância da universidade com o compromisso de mudança e social reproduzindo exclusões sociais (Chaui 2003, p.13), faz com que as universidades passem a produzir comódites e conhecimentos tecnocráticos retroalimentando o processo de mercantilização (Apple 1993, p.309). Assim, a mercantilização da universidade rói o que Karpov (2013, p.34) chama de seu caráter epistêmico, isto é, seu papel social na produção e análise crítica dos conhecimentos.

A relação entre população e universidade também é afetada, principalmente no que se refere os primeiros enquanto candidatos de vestibulares e estudantes universitários. Consolidou-se a ideia de que os estudantes enquanto 'seres consumidores', o que reforça a ideia de que um diploma universitário é também uma comódite, que pode ser 'trocada' por um emprego ou por uma promessa de ‘vida melhor' (Ball 2004, p.5) - o análogo vale para diplomas de pós-graduação, em especial no caso de mestrados e doutorados profissionais, cujas criações resumem-se em grande parte em políticas para atender 
demandas dos setores produtivos ${ }^{24}$ (Accioly, Gawryszewski \& Nascimento 2016, p.33). Tal ideia, somada ao pano de fundo da realidade brasileira do ensino superior, é catastrófica - apenas amplia a dualidade educacional (ibid., p.28) entre o ensino superior disponível economicamente às classes altas (em geral universidades públicas ou privadas de alta qualidade) e aquele às classes baixas (majoritariamente instituições privadas, de péssima qualidade).

Além das consequências discutidas acima, a mercantilização das universidades e da educação deixam o espaço ainda mais livre para políticas de reformas educacionais, de ‘reformadores empresariais’ (Freitas 2016) - sendo que, para justifica-las, é praxe usar o subterfúgio de 'crises financeiras’ (Karpov 2013, p.30), uma variante da estratégia neoliberal já mencionada (Hall 2011). Por outro lado, a agenda neoliberal conta com mecanismos que implicam em tetos financeiros nos gastos públicos (Ostry, Loungani \& Furceri 2016, p.40), o que, naturalmente, deixa a educação (e outros setores públicos) à mercê da mercantilização - tal qual a situação brasileira, após a aprovação da proposta de emenda constitucional 95/2016.

A respeito do interesse explícito de grupos privados acerca do amálgama entre educação e trabalho, deixando a debate a natureza em si problemática ou não desta, é importante lembrar que não é novidade este discurso se fazer presente em documentos educacionais oficiais. Tais interesses de grupos privados sobre a educação têm ganhado força nos últimos anos, imprimindo suas influências social e politicamente, e não raro acabam por compor a 'voz mais ouvida' em políticas curriculares (Apple 1999, p.11). Não é raro o argumento da necessidade de "flexibilizar percursos de aprendizagem" e atender os supostos “anseios da juventude” (Castro 2008, p.93), e também aquele de que a educação básica não 'prepara para o mundo' fornecendo 'habilidades' essenciais, sugerindo que os currículos não voltados ao mercado de trabalho são irrelevantes (Jimenez, King \& Tan 2012, p13). De acordo com Leher e Vittoria (2016, p.107), é do interesse desses grupos e dos setores dominantes que a educação tenha como função a

\footnotetext{
${ }^{24}$ Os doutorados profissionais CAPES foram instituídos em março de 2017. Em entrevista à coordenadora de avaliação da CAPES, Rita Barata, foi afirmado que o "doutorado profissional é destinado à formação profissional de alta qualidade, formação essa que pretende embasar a atuação profissional no desenvolvimento científico e tecnológico", e que um dos objetivos centrais do mestrado e doutorado profissionais "é ampliar a produção de pesquisas estratégicas e o desenvolvimento tecnológico nos setores produtivos (agricultura, indústria e serviços) e no setor de políticas públicas”. Disponível em http://www.anped.org.br/news/entrevista-com-rita-barata-capes-doutorados-profissionais, acesso outubro de 2017. É oportuno mencionar que, do período de 1998 a 2010, enquanto o número de programas de mestrado e doutorado acadêmicos aproximadamente dobrou, o número de programas de mestrado profissional multiplicou-se mais de dez vezes (Accioly, Gawryszewski \& Nascimento 2016, p.31). Fonte CAPES, disponível https://www.capes.gov.br/component/content/article?id=4439, acesso outubro de 2017.
} 
transformação de conhecimento e treinamento em 'capital humano, ${ }^{25}$ - raciocínio que embasa, segundo Júnior e Maués (2014, p.1148), a popular - porém falsa - ideia de que “ $a$ educação seria a grande panaceia para superar a pobreza e as desigualdades sociais em termos tanto macro como microeconômicos". Nota-se que este mito é baseado fortemente numa concepção economicista de educação.

Sobre o direcionamento da educação ao mercado de trabalho, é oportuno citar o comentário de Maria Helena de Castro (2008) acerca da proposta de reformulação curricular do Estado de São Paulo (à época):

(p.97) Currículo é cultura; Currículo referido a competências; Currículo que tem como prioridade a competência leitora e escritora; Currículo que articula as competências para aprender; Currículo contextualizado no mundo do trabalho.

(.) A proposta curricular procurou responder às expectativas dos jovens paulistas e contempla também uma diversificação do ensino médio em duas vertentes: de um lado, a inclusão concomitante de formação profissional de nível técnico e, de outro, a inclusão de componentes curriculares de apoio à continuidade de estudos. (...).

É notável acima o uso de recortes de discursos aparentemente progressivistas e, claro, a menção explícita do ‘currículo contextualizado no mundo de trabalho’. Por outro lado, o mais relevante nesta questão é que, além podermos entender a autora como uma representante de um bloco conservador modernizador brasileiro (cf. Apple 2016), ela particularmente tem tido considerável influência nas políticas curriculares brasileiras em especial no pós-impeachment de 2016. O seu discurso, assim como outras vozes neoconservadoras, transmite uma aparente boa intenção das reformas e políticas educacionais no seio neoliberal que ocultam o potencial destas em reproduzir ou piorar as desigualdades sociais (Apple 2009, p.241).

De fato, as reformas educacionais nas últimas décadas, como a mencionada acima e também a recente sobre do ensino médio brasileiro, apresentam como uma forte tendência o discurso da 'ampliação da possibilidade de escolhas', visando fomentar mecanismos de competição entre escolas, o que supostamente induziria à melhoria de suas qualidades (Bauer, Alavarse \& Portela 2015, p.1369). A lógica da competição é explicitamente

\footnotetext{
${ }^{25} \mathrm{O}$ termo de 'capital humano’ pode referir-se a diferentes quadros teóricos. Referimo-nos no texto à Teoria do Capital Humano, resumida por Júnior e Maués (2014, p.1148) com base na ideia de que é uma "quantidade ou um grau de educação e de qualificação, tomado como indicativo a um determinado volume de conhecimentos, habilidades e atitudes adquiridas, que funcionam como potencializadoras da capacidade de trabalho e produção".
} 
defendida por Castro (2009), vestida dos discursos de 'incentivo com remuneração por desempenho' (ibid., p.16) e 'política de reconhecimento de esforço' (idem). Além da possibilidade de escolhas, caracterizam as reformas educacionais das últimas décadas a centralização do sistema de avaliação, descentralização da gestão e intensificação da lógica de valorização de resultados e 'eficiência' do serviço ofertado - school effectiveness e accountability (Bauer, Alavarse \& Portela 2015, p.1369). As retóricas utilizados em tais reformas pode ser muito bem caracterizados pela consideração de Bernstein (2000b, p.69) acerca do que chama 'identidade pedagógica descentralizada tipo mercado, $^{26}$ :

\begin{abstract}
O sistema de gestão aqui é explicitamente hierarquizado, comissões pequenas e não-eleitas, poucas em número, que distribuirão recursos para unidades locais, de acordo com sua eficiência e seus procedimentos de prestação de contas. A administração revela-se principalmente para distribuir recompensas e punições. A gerência monitora a eficácia das unidades, grupos ou departamentos locais na satisfação e criação de mercados locais. A transmissão aqui surge para produzir uma identidade cujo produto possui um valor de troca em um mercado. O foco é sobre os insumos que otimizam esse valor de troca. Temos aqui uma cultura e contexto para facilitar a sobrevivência do mais apto, conforme julgado pelas demandas do mercado.
\end{abstract}

Os apontamentos acima reforçam de certa forma aquilo que Apple (2004, p.ix) identifica como umas primeiras lições aprendidas enquanto professor e pesquisador - que os elaboradores de currículos vivem um mundo à parte daqueles que realmente existem e se manifestam nas escolas. E no cenário brasileiro não é diferente. Como indica Freitas (2016, p.138), nos anos que virão “a política educacional no Brasil deverá passar por uma inflexão que a levará a conhecidos problemas (...) oriundos das propostas de 'responsabilização baseada em avaliação e pressão' sobre as redes públicas”, abrindo mais ainda as portas para a mercantilização da educação. De fato, além da responsabilização, a política de constranger escolas mal avaliadas já foi abertamente defendida, por exemplo, por Castro (2011, p.4) como uma forma de melhorar os índices de avaliação da escola básica. Os conhecidos problemas mencionados por Freitas podem incluir muito daqueles analisados e debates por Apple no contexto estadunidense - em

\footnotetext{
${ }^{26}$ Uma breve definição de identidades pedagógicas por Bernstein será fornecida oportunamente no capítulo seguinte.
} 
especial, aqueles originados das políticas No Children Left Behind (NCLB), no governo Bush, e o Race To The Top (RTTT), no governo Obama.

Os desdobramentos da reforma NCLB de 2001 - o qual em 2015 foi substituído pelo Every Student Succeeds após críticas vindas de vários lados do espectro político estadunidense - podem servir de parâmetro para o futuro cenário da educação brasileira caso as atuais políticas educacionais continuem na mesma tônica. Em síntese, o NCLB veio a funcionar efetivamente como uma política de avaliações padronizadas pautada na lógica de responsabilização, com testes centralizados em cada estado, e com o estabelecimento de objetivos que, caso não alcançados, incorreriam em intervenções e alterações no financiamento às escolas (Apple 2005, p.20). Naturalmente, tal tipo de política implica, em geral, num forte controle curricular (ainda que indireto) e ainda um substancial condicionamento das atividades e atuações de professores e estudantes (cf. Au 2011). O controle e estreitamento curricular levam ao estabelecimento de 'conhecimentos oficiais’ (justamente aqueles presentes no currículo), à custa da exclusão de outros. A associação destas políticas com um currículo centralizado ou comum - o que está iminente no contexto brasileiro se levarmos em conta o direcionamento tomado nas BNCC em suas últimas versões - estabelece e cristaliza um processo de padronização em escala nacional (Freitas 2016, p.142).

O RTTT na gestão Obama veio a inflamar a competição entre professores e gestores entre os estados, estimulando medidas em que o pagamento de professores fosse pautado nos resultados dos testes estandardizados de seus estudantes (Apple 2011, p.24). A publicação dos resultados - contendo os 'perdedores' e os 'vencedores' e suas cifrasserviria também de parâmetro para pais e responsáveis sobre a ‘qualidade’ das escolas, orientando suas escolhas. Paralelamente, a ideologia meritocrática e individualistacompetitiva subjacente à medida ataca a coletividade de professores e enfraquece o poder de luta dos sindicatos (Au 2013, p.10). Como afirma Apple (2005, p.27):

(...) o movimento rumo à mercantilização e "escolha" requer a produção de informações estandardizadas baseadas em processos e "produtos" estandardizados, de tal forma a possibilitar comparações para que os "consumidores" tenham informações relevantes a fim de fazerem suas escolhas no mercado.

Os exemplos do NCLB, RTTT e diversos outros mostram como o Estado - enquanto sujeito aos setores dominantes da sociedade - pode ser um forte contribuinte ao fenômeno 
de mercantilização da educação (Leher \& Vittoria 2016, p.108). A transformação daquilo que seria direitos sociais elementares - como saúde, segurança e, principalmente, educação - em comódites por meio de 'reformas empresariais' (Freitas 2016) ou medidas de incentivo a grupos (monopólios) privados é outro exemplo (Leher \& Vittoria 2016). É possível incluir neste conjunto o incentivo à educação à distância (EaD), saudada por autores como Schwartzman (2016, p.181) como 'nova tecnologia' e inovadora, enquanto via principal de educação (e não coadjuvante ou complementar). A defesa acrítica da EaD, a qual representa hoje aproximadamente $20 \%$ das matrículas brasileiras em instituições de ensino superior privadas, oculta a progressiva deterioração da profissão docente (Leher 2016, p.xii).

Tais tipos de políticas educacionais, além de refletirem o quão aparte é o mundo em que os elaboradores de currículos vivem, mostram a visão essencialmente economicista sobre educação que hoje vigora - tanto nas arenas política e econômica como também no pensamento popular. Apple argumenta que as alianças internas ao bloco conservador modernizador e a maneira como articularam temas que ressoam bastante com os receios diários da população foram centrais para a ‘popularização do conservadorismo’ (Apple 2009, p.239) - um elo destes temas é a religiosidade e seu apego popular, a qual para Apple (ibid., p.245) a nova direita utilizou-se para tentar atrair diversos grupos religiosos.

A visão economicista sobre a educação é a responsável pela ideia de que os investimentos em educação pública são ‘desperdício’, e que o dinheiro deveria ir para aplicações privadas. Escolas e outros serviços públicos são entendidos como 'buracos negros’ de dinheiro (Apple 1999, p.9). Paralelamente, os cursos de licenciatura são entendidos como 'habilitações rápidas’ para ingresso imediato no mercado de trabalho (Chauí 2017, p.60) - 'transmissão e adestramento' tomam o lugar de 'formação', docência é vendida como 'segunda renda' e não propriamente como uma profissão ${ }^{27}$. Ainda, ao se tratar a educação como uma empresa, um corolário da visão economicista, se

\footnotetext{
${ }^{27}$ Referimo-nos a uma criticada propaganda da empresa Anhanguera Educacional, filha da Kroton Educacional, publicizada em meados de 2017 acerca da oferta do curso de 'Formação pedagógica' como segunda graduação. Após forte reação nas redes sociais e movimentos sociais, a empresa desculpou-se em nota. É curioso, todavia, que o apelo propagandístico da empresa ao curso, que pode ser encontrado em seu portal (http://anhanguera.com/graduacao/cursos/formacao-pedagogica.php, acesso outubro de 2017), atenta para o 'bom momento para ingressar nesse mercado' com chances de desemprego baixas - concebendo a docência enquanto comódite, como uma 'negócio' interessante no momento, com baixas chances de 'perda', poder-se-ia dizer tal qual numa bolsa de valores.
} 
entende como 'natural' que seu maior problema não é a falta de recursos, mas 'má gestão’, 'pouca eficiência’ (Castro 2011, p.7-8) ${ }^{28}$.

Ainda nessa via, entende-se o investimento na educação, em demandas tais como a já mencionada meta de $10 \%$ do PIB defendido por movimentos sociais e líderes sindicais, como ‘extremamente elevado’ (Júnior \& Maués 2014, p.1149). Outro corolário de tal visão é que o imperativo central das reformas educacionais recentes é de natureza econômica, incluindo seus intentos enquanto políticas de acesso - os objetivos são a estabilidade político-econômica e "evitar protestos e descontentamento social" (World Bank apud Júnior \& Maués 2014, p.1141), sob as égides da ‘inclusão’ e ‘igualdade de oportunidades'.

Conforme discutiremos nas próximas seções, a ideologia neoliberal encarrega-se de 'naturalizar' a mercantilização da educação, assim como as políticas educacionais neoliberais. Desta forma, os currículos, palcos de disputas entre visões de escola e sociedade, ficam sujeitos a interesses que representam os interesses de grupos economicamente dominantes - como o bloco conservador modernizador alertado por Apple -, fazendo os objetivos da educação e até mesmo o conhecimento específico das disciplinas escolares serem guiados mercadologicamente. Apple (2009, p.242) elenca pelo menos três forças que atuam fortemente no debate sobre o que deveria ser ensinado nas escolas: (i) neoliberais, que criticam conhecimentos 'economicamente inúteis'; (ii) neoconservadores, que reclamam da falta de disciplina moral e dos 'conhecimentos canônicos’, e; (iii) populistas religiosos autoritários, que acusam a suposta perda dos 'valores tradicionais’ no sistema educacional.

Segundo Buras e Apple (2009, p.20), o segmento dos neoconservadores defende o 'retorno' ao 'conhecimento canônico', ou 'tradicional', sendo que por vez através dos mecanismos de avaliação e currículos padronizados, e paralelamente, oferece resistência à 'ameaça multicultural' na educação ${ }^{29}$. Tal ideia de 'conhecimento tradicional' está no cerne do neoconservadorismo educacional - enquanto uma identidade pedagógica

\footnotetext{
${ }^{28}$ É, por exemplo, o que se exprime da afirmação categórica do ministro da Educação José Mendonça Filho, já no contexto do governo interino pós-impeachment, em entrevista em dezembro de 2016: "Em 12 anos, foi triplicado o investimento na área, de R\$ 43 bilhões para mais de R\$ 130 bilhões, mas o desempenho da educação pública ficou estagnado. Queremos mais efetividade no investimento" (grifos nossos). Disponível em https://g1.globo.com/pernambuco/noticia/triplica-se-o-investimento-mas-aeducacao-nao-melhora-diz-ministro-ao-defender-a-pec-55.ghtml, acesso em julho de 2017.

29 'Conhecimento tradicional' e 'multiculturalismo' são termos envoltos num embate controverso e que podem carregar uma miríade de significados. Como será discutido em capítulo posterior, resumidamente, entendemos que o primeiro, no caso da ciência, reflete uma concepção a-histórica e a-social da ciência, e o segundo, ainda que tenha um valor didático importantíssimo, não deve tomar o lugar específico dos conhecimentos poderosos nos currículos.
} 
prospectiva, nas palavras de Bernstein (2000b, p.68) -, no qual o passado é seletivamente recontextualizado com o fim de defender uma visão que 'estabilize o futuro, ${ }^{30}$. No contexto da ciência e da ciência escolar (e, mesmo além da escola), isto se traduz numa ideologia cientificista, que carrega ideias de progresso histórico linear e realismo ingênuo (como 'desvelamento da realidade' (Cardoso et al 2015)) - muito próximas das concepções classificadas como inadequadas da NdC no EC (McComas 1996), ou que Apple (2004) chamou de visão positivista de ciência.

Abordaremos na próxima seção uma manifestação específica da mercantilização, na forma de políticas de avaliações padronizadas e padronização-estreitamento curricular, e procuraremos mostrar como o apelo de autores - com largo histórico de contribuições na área de pesquisa de EC, é preciso reconhecer - como Lederman (Lederman \& Lederman 2014b), McComas (McComas \& Nouri 2016) e outros acerca da inclusão da VCnNdC em testes padronizados estadunidenses não deve ser compartilhado. Tomando que o contexto estadunidense atual quanto a políticas educacionais é um possível futuro quadro da situação brasileira (Freitas 2016), salvo naturalmente as especificidades destes países, nosso apelo vai em direção contrária. A possível inclusão da $\mathrm{NdC}$, especialmente na forma de tenets, em testes padronizados não deve ser celebrada, mas criticada.

\subsection{Avaliações padronizadas e a visão consensual da natureza da ciência}

A ideia de avaliar estudantes por meio de exames padronizados escritos teve, como local de uma de suas primeiras ocorrências, a cidade estadunidense de Boston, em 1845 (Bauer 2010). Por trás da iniciativa, além da meta de 'justiça nos julgamentos’, 'comprovados' pelos dados dos testes, havia o objetivo de aferir a 'eficiência' de escolas de compara-las entre si. A criação do que poderíamos chamar de ‘tradição de Boston’ foi um marco na história da avaliação (idem), e, infelizmente, ainda está muito viva mesmo quase duzentos anos depois. Avaliações padronizadas centralizadas em escala nacional, tidas hoje como 'medidas naturais’ em políticas públicas educacionais em diferentes países, têm, por outro lado, uma história mais recente. No caso estadunidense, uma

\footnotetext{
${ }^{30}$ Esclarecendo, consideramos que a-historicidade não é só a falta de história, mas também este caso de distorção deliberada que acaba por fortalecer uma ideologia, a qual em seção posterior chamaremos de cientificista-positivista.
} 
origem mais concreta seria a reforma A Nation at Risk (NAR) na década de 1980 no governo Reagan - com a retórica de que a educação pública estava falida, que era culpada do recesso econômico-tecnológico, e que a solução seria incentivar a competitividade nas escolas, fazendo-as servirem a economia (Weinstein 2017, p.824). Isso abriu possibilidades para políticas de padronização de currículos e, principalmente, padronização de testes - as quais tiveram consequências negativas complexas, nem sempre intencionais (idem). Entre estes, a criação do (poderoso) mercado de materiais educacionais (padronizados), o fechamento de escolas 'abaixo das expectativas' e privatizações forçadas (ibid., p.825) - como será comentado novamente ainda nesta seção. O NCLB foi um ponto vernal quanto à adoção desenfreada de políticas de testes padronizados (Weinstein 2017, p.825).

Em linhas gerais, a coexistência das lógicas de 'centralização para avaliar' e 'descentralização para gerir', tão presente nas políticas educacionais recentes, é um traço característico do neoliberalismo na educação (Apple 2001, p.111). Tal como no contexto estadunidense - onde os atos recentes NCLB e RTTT, associados a uma base comum (Common Core), tornaram a lógica de testes padronizados ubíqua (Au 2013, p.7) -, no Brasil a centralização dos sistemas de avaliação com o objetivo de estabelecer padrões de desempenho também se faz presente (Junior \& Maués 2014, p.1140). Exemplos são o SAEB (Sistema de Avaliação da Educação Básica) criado em 1990 e o ENEM em 1998. Pode-se entender que mesmo a LDB 9394/96 (Brasil 1996) reflete esta centralização na avaliação (idem) - de fato, como mencionado na seção anterior, esta é uma das características recorrentes em reformas educacionais nos últimos vinte anos (Bauer, Alavarse \& Portela 2015, p.1369), ancoradas na ilusão ingênua do alto poder indutor otimizador dos testes padronizados sobre escolas e professores (ibid., p.1379). Outra ilusão é a suposta 'objetividade' em medir o intelecto humano de forma neutra - a qual particularmente no contexto estadunidense tem sustentação nos ideários liberais de 'equidade individual' (igualdade de oportunidades), mérito e esforço (Freitas 2016, p.148). Tal ilusão já foi usada para classificar de forma cientificista pobres, imigrantes, mulheres e não-brancos como 'mentalmente inferiores’ (Au 2013, p.9). Com efeito, os testes padronizados exigem estatisticamente que haja perdedores - como na lógica de mercado -, de tal forma que caso houvesse apenas vencedores, “os resultados dos testes seriam imediatamente questionados, seja tecnicamente (p.e., há algo errado com o teste), ético-politicamente (p.e., alguém trapaceou), ou ambos” (ibid., p.14). 
Bauer, Alavarse e Portela (2015) sumarizam os argumentos favoráveis aos testes padronizados para quem justamente os controla - aqueles que gozam de poder financeiro, político e indutor (ibid., p.1370). Para estes, os testes padronizados: (i) responsabilizam professores, gestores e escolas pelos resultados, e induzem à subsequente prestação de contas e ao (suposto) comprometimento com a melhor aprendizagem dos estudantes (de acordo com os padrões); (ii) criam uma cultura de avaliação e transparência dos serviços públicos (isto é, dos resultados); (iii) dão poder de escolha dos pais sobre as escolas com base nos resultados (uma vez tornados públicos) dos estudantes; (iv) permitem comparações pelo gestor entre perfis dentro escola e com toda rede educacional; (v) são neutras e objetivas, seus resultados são precisos e têm credibilidade; (vi) criam banco de dados objetivos, que podem ser analisados estatisticamente de forma a acompanhar a evolução da educação, divididos por categorias referentes às características de escolas, professores e estudantes; (vii) responsabilizam os estudantes, induzindo-os a se esforçarem para melhorar seus resultados; (viii) estimulam a adequação de currículos inadequados, e; (ix) fomentam medidas que visam maior equidade nos resultados (ibid., p.1371). Em suma, nas palavras de Castro (2009, p.6), os testes padronizados têm papel fundamental em:

\footnotetext{
(...) melhorar as economias nacionais, estabelecendo vínculos mais fortes entre escolarização, emprego, produtividade e mercado; melhorar os resultados de aprendizados relacionados às competências e habilidades exigidas pelo mercado de trabalho; obter um controle mais amplo dos sistemas educativos nacionais sobre os conteúdos curriculares e a avaliação; reduzir os custos dos governos na educação; e ampliar a contribuição da comunidade para a educação por meio de sua participação na tomada de decisões escolares. (grifos nossos)
}

Contudo, se por um lado os 'resultados mensuráveis' são tidos como panaceias para a educação (World Bank apud Jimenez, King e Tan 2012, p.14), análises gerais sobre testes padronizados mostram que tais políticas não acarretaram melhora significativa nos índices de aprendizagem - tão pouco reduziu o (quase sempre frequente) gap entre estudantes de classes baixas e altas (Au 2013, p.12). De fato, como novamente sumarizam Bauer, Alavarse e Portela (2015, p.1375), existem também diversos argumentos críticos contra os testes padronizados, alguns deles já mencionados anteriormente: (i) responsabilização repreensiva pode gerar medidas injustas com professores gestores e escolas; (ii) autonomia de professores e estudantes é minada; (iii) testes padronizados 
incentivam a competição escolar, desvirtuam o papel da educação levando a o que $\mathrm{Au}$ (2011) chama de 'teaching to test'; (iv) o contexto dos estudantes, seja local (na hora da prova) ou histórico (realidade social-escolar e dificuldades pessoais) é completamente negligenciado; (v) geram afunilamento curricular, desmembram os conhecimentos escolares em partes desconexas, têm a força de subdeterminar os tempos de aulas privilegiando conhecimentos de testes; (vi) são pontuais e parciais, incapazes de apreender o desenvolvimento mais geral ao longo do período escolar; (vii) lógica da premiação gera injustiça - e seu lado oposto, lógica da culpa pelo fracasso, não é enfatizado; (viii) induzem a políticas gerenciais voltadas exclusivamente à melhora dos resultados, como o controle e exclusão de alunos 'ruins' por gestores; (ix) geram uma enorme carga de pressão sobre professores e estudantes, que pode levar a problemas de saúde e desmotivação quanto à escola, e; (x) somando-se a pressão dos testes e as políticas gerenciais induzidas, podem levar ao aumento da desigualdade, dado que estudantes 'mais aptos’ têm mais condições de ‘sobreviver' aos exames.

Por outro lado, ainda que os reformadores empresariais reconheçam muito dos problemas acima elencados com as políticas de testes, eles 'resolvem-se' de diferentes maneiras, tais como: (i) argumentar pelo "poder da escola para 'compensar' a pobreza com uma 'ação eficaz"” (Freitas 2016, p.148) e enfatizam o papel dos professores e gestores em superarem (como 'heróis') as dificuldades e 'vencerem' - afinal, pobreza, segundo os reformadores, não seria desculpa para não ensinar ou aprender (idem); (ii) naturalizar a existência de 'perdedores', por uma questionável argumentação sóciodarwinista-liberal (Apple 2001, p.104) de que 'todos somos diferentes' e que temos 'igualdade de oportunidades’ (Freitas 2016, p.149). Daí umas das fontes da enorme pressão sobre professores e estudantes, como assinalado acima. Os efeitos disto vão desde a internalização do fracasso como um problema individual, de 'falta de esforço', de 'incapacidade’ até autodepreciações fatalistas ('não nasci para isto’), o que leva muitas vezes a uma penosa vivência rotulada negativamente (Apple 1989, p.74).

Em síntese, discursos de equidade e accountability, presentes a propósito no NCLB e RTTT, ocultam tanto a enorme pressão sobre professores e estudantes por resultados nos testes padronizados como o aprofundamento do gap entre estudantes de condições sociais frágeis e privilegiados nestes (idem). Bauer (2010, p.325) lembra que o debate acerca do accountability das escolas traz muitas vezes discursos aparentemente democráticos, usando apelos legítimos como o da transparência de informações - mas que nada mais serve que para o controle de determinados grupos sobre sistemas educacionais. Por outro 
lado, os testes padronizados - juntamente com a já mencionada estratégia neoliberal de forçar o sucateamento e a ‘ineficiência’ do setor público -, não raro funcionam como mais uma ferramenta de imposição de reformas mercantilizantes justificadas pelo 'desempenho ruim’ daqueles (Bauer, Alavarse \& Portela 2015, p.1372). Neste espírito, os professores, estudantes, e também os currículos acabam por atender aos exames e testes (e não o oposto), como é sugerido na citação abaixo de Castro (2009, p.14) acerca da (à época) reforma curricular estadual paulista:

Era preciso implantar uma base curricular comum nos ensinos fundamental e médio, inspirada pelas diretrizes curriculares nacionais e apoiada na Matriz Curricular do Saeb, para que professores e alunos conhecessem os conteúdos, competências e habilidades que seriam objeto da avaliação anual de todas as escolas estaduais.

A postura explícita de Castro, assim como o exemplo estadunidense, reforça a afirmação de Apple (p.111) de que a associação de uma base curricular comum acoplada a políticas de testes padronizados centralizados - especialmente vinculados à lógica de responsabilização - é um passo essencial em direção à intensificação da mercantilização da educação. Além disso, releva os grandes equívocos da visão economicista-neoliberal sobre o que é uma boa educação, avaliação e o ato de ensinar (Apple 2005, p.25) - sem mencionar sua tendência em definir o 'conhecimento oficial' e desmerecer o papel de culturas locais no processo educativo ${ }^{31}$. O estreitamento curricular sucede-se no sentido de ‘enxugar’ o currículo ao ‘necessário’ (testes e mercado de trabalho), deixando de lado tópicos fundamentais para a educação básica dos estudantes em idade escolar (Bauer, Alavarse \& Portela 2015, p.1374).

Como já mencionado, a pressão dos testes sobre professores e alunos reduz drasticamente a autonomia de ambos nos processos de ensino-aprendizagem em sala de aula. Au (2009, 2011, 2013) ilustra e analisa este fenômeno e suas consequências no contexto estadunidense. O controle técnicista sobre a ação docente (Au 2011, p.30) vem lado a lado a outros fatores, como o espelhamento dos currículos às estruturas dos testes (idem), fragmentação do conhecimento em testes (e, logo, no currículo) - em operações, fatos desconexos, recursos mnemônicos (ibid., p.31)- e também as atuais políticas de livros-didáticos que implicam em obras ‘padronizadas’ (ibid., p.32). Tal tipo de controle

\footnotetext{
${ }^{31}$ Tal questão é especialmente central para Apple no contexto estadunidense. No Brasil a questão é igualmente relevante, e constantemente levantada por autores multiculturalistas. Esse assunto será retomado no próximo capítulo.
} 
faz com que professores precisem contar menos com seu conhecimento específico e sua didática para ser guiados ou por apostilas didáticas padronizadas, por norteamentos de testes estandardizados ou pelo currículo condicionado por estes (ibid., p.34) - desta forma, "a padronização do ensinar por meio dos testes permite um crescente controle administrativo gerencial sobre os professores (trabalho) e estudantes (produtos) nos processos educacionais” (ibid., p.35). Isto está na base da precarização da carreira docente, processo que se intensifica em taxa proporcional ao crescimento de licenciaturas extremamente frágeis (principalmente em instituições de ensino privadas), da falta de reconhecimento social e subvalorização da carreira docente, entre outros.

O instrucionismo alienado, balizado por um controle quase fabril, pode forçar os professores a atitudes lastimáveis - um exemplo particularmente icônico é mencionado por Au (ibid., p.33), acerca das instruções de um programa de ensino de matemática estadunidense que sugere ao professor, no caso de dúvidas de um estudante, "repetir exatamente a mesma frase que acabou de ser dita” (idem). Partes significativas das aulas são usadas para abordar tópicos dos testes, no estilo de treinamento-adestramento (Bauer, Alavarse \& Portela 2015, p.1373). Isto induz, segundo, Au (2011, p.38) a um tipo de neotaylorismo educacional, com o qual "professores-enquanto-operários trabalham numa eficiente linha de montagem educacional taylorizada 'produzindo' estudantesenquanto-comódites”, de tal forma que o valor social-mercadológico destas personagens é 'medido' via os testes. As etapas finais do neotaylorismo educacional resumem-se à variante da estratégia neoliberal já citada (Hall 2011; Bauer, Alavarse \& Portela 2015, p.1372): culpabilização das escolas - especialmente as do sistema público - por serem 'ineficientes' nos testes, seguida da defesa de que isso pode ser superado pela iniciativa privada, por meio de medidas 'racionalizadas' e ‘eficientes’ (Chaú́ 2017). Dificilmente o substrato deste fenômeno escolar analisado por Au poderia ser mais bem traduzido do que o entusiasmo de Castro (2011, p.10) pela presença do empresariado na educação brasileira, para quem “a melhoria de muitos sistemas municipais e até estaduais está associada à presença e atuação de algumas dessas filantropias [fundações empresariais]”.

Tais argumentos de supostas melhoras nos sistemas educacionais, seja pela ação direta ou indireta do empresariado, seja por meio de uma ‘indução’ pelos testes, são, portanto, questionáveis (Au 2013, p.12). Todavia, tão importante quanto esta questionabilidade, é preocupante o fato que muitas políticas de testes padronizados acabaram por gerar um deslocamento das preocupações da 'qualidade de educação' para 'qualidade dos 
resultados’ (Bauer, Alavarse \& Portela 2015, p.1374) - disto vem, por exemplo, uma crítica ao ranqueamento feito pelo PISA por dar pouca visibilidade a referências específicas aos contextos nacionais, o que se torna mais grave dado sua alta influência sobre a opinião pública (ibid., p.1377). Os argumentos exaltando os efeitos positivos dos testes padronizados raramente vêm acompanhados de uma ponderação crítica sobre a acurácia dos mesmos - ou, com a modesta consideração de que em geral eles não são tão acurados quando se advoga (Au 2013, p.15).

A preocupação desmedida na 'qualidade dos resultados' pode ocultar realidades sociais bastante preocupantes. Um exemplo relativamente recente pode ser encontrado no contexto do Chile, país melhor colocado no exame PISA na América do Sul (Schwartzman 2015). Durante o governo militar chileno nos anos 1980s, o sistema de vouchers foi introduzido em escolas privadas e públicas, sendo que a gestão destas pulverizou-se da esfera federal a níveis locais (ibid., p.11). Os intuitos foram aumentar a competitividade entre escolas e estudantes, enfraquecer sindicatos de professores, atrair investimentos privados e livrar o sistema educacional de "burocracias governamentais" (idem) - em outras palavras, minimizar o papel do Estado na educação. O resultado de início foi o aumento da desigualdade e do número de instituições privadas de ensino. Até muito recentemente, instituições privadas tem tido melhores resultados em testes (idem) todavia, isto se dá sobre um pano de fundo em que quase metade dos estudantes de ensino básico depende do sistema de vouchers ${ }^{32}$ e de inúmeras acusações de lucros ilícitos de universidades pagas (Mönckeberg 2007). As fortes manifestações estudantis de 2011 e 2012 deixaram evidente a insatisfação geral dos estudantes chilenos com a já avançada privatização da educação em seu país - e também, que o custo social de 'boas avaliações internacionais' pode ser caro e perigoso, podendo levar a uma enorme dependência do setor privado.

Na tentativa sumarizar esta discussão, Au (2009, p.140) argumenta que o currículo oculto dos testes padronizados é o fato de que são desiguais por design - isto é, criam as desigualdades 'verificadas' nos resultados, contribuem para (re)produção das desigualdades e acabam por justificar, no contexto de seu país, o que chama de 'meritocracia estadunidense'. A suposta 'objetividade' dos testes e a ideologia meritocrática - ou, a ideia de que, independentemente das origens sociais, classe, gênero, ou contexto cultural, é possível o indivíduo ser ‘bem sucedido’ - mascaram as

32 Fonte: Indicadores de la Educación em Chile 2007-2008. Disponível em http://w3app.mineduc.cl/mineduc/ded/documentos/Indicadores_2007-2008.pdf, acesso em julho de 2017. 
desigualdades estruturais pelo discurso naturalista de que existem 'mais aptos' e que os testes são ‘justos' (no sentido de uma suposta igualdade de oportunidades de partida) e fundamentados 'cientificamente’ (Au 2013, p.13). A desigualdade por design, esclarece Au (2009, p.143), é ao mesmo tempo (i) um produto consciente de relações humanas e sociais, e (ii) um processo sobredeterminado ${ }^{33}$ pelas estruturais sociais e econômicas do meio no que se manifesta - assim a concebendo, desnaturaliza-se a desigualdade e evidencia a natureza ideológica da postura de negligenciar da sua natureza histórica, social, empírica e política. Por outro lado, para Au (2009, p.145), isto significa que as avaliações em larga escala são, portanto, também potencialmente ‘iguais poder design’ elas não são um 'mal em si', sendo sim problemático seu uso aos moldes neoliberais (Bauer, Alavarse \& Portela 2015, p.1369). A educação, não sendo um mercado - onde há naturalmente perdedores e vencedores - deve, por sua natureza social-epistêmica, consagrar apenas vencedores (Freitas 2016, p.145).

A despeito das políticas de testes, uma discussão em voga - não, porém, nova, como esclarecemos em capítulo anterior - é a inclusão (ou não) da NdC em documentos curriculares (e, consequentemente, nos testes) (Lederman \& Lederman 2014b; McComas \& Nouri 2016). Especificamente no contexto estadunidense, em documentos educacionais relativamente recentes - como o Project 2061 de 1989, o Benchmarks of Science Literacy de 1993 - não houve uma maior ênfase em tópicos de NdC como aconteceu com o texto National Science Education Standards (NSES) de 1996, que considerou mais concretamente trabalhos de pesquisadores de EC sobre o tema (McComas 2015). Como comentam Lederman e Lederman (2014b, p.235), NdC era considerada como tópico de ensino ao lado de Leis de Newton, Fotossíntese, índice $\mathrm{pH}$, entre outros. Isso mudou drasticamente na versão revisada do documento Next Generation Science Education Standards (NGSS) de 2013, cujo papel é tão central quanto o common core. Neste, a NdC foi considerada um subconjunto de práticas científicas, um tema transversal sem proeminência - uma mudança que motivou a crítica-paródia de Lederman com a expressão ‘a NdC deixada para trás' ('Nature of Science Left Behind'), em referência à sigla da reforma NCLB (idem). Para Lederman e Lederman (ibid., p.236), a forma como a NdC foi abordada no NGSS implica num retrocesso, incentivando uma suposta confusão entre NdC e ‘ensino por investigação’ e ignorando resultados de anos de pesquisa na área (idem).

\footnotetext{
${ }^{33} \mathrm{Au}$ utiliza o termo 'over determination', uma tradução direta do francês 'surdétermination', usado por Althusser (1984), a quem o autor referencia explicitamente.
} 
Resumidamente, o NGSS (2013b) introduz um conjunto de oito asserções simples e curtas sobre a NdC - muito semelhantes em forma e conteúdo às listas da VCNdC de Lederman e McComas, que no documento são chamadas de 'matriz de conhecimentos básicos sobre a NdC’

(I) Investigações científicas usam uma variedade de métodos

(II) Conhecimento científico é baseado em evidências empíricas

(III) Conhecimento científico é aberto a revisões à luz de novas evidências

(IV) Modelos científicos, leis, mecanismos e teorias explicam os fenômenos naturais;

(V) Ciência é uma forma de conhecer o mundo

(VI) Conhecimento científico assume uma ordem e consistência em sistemas naturais

(VII) Ciências é um empreendimento humano

(VIII) Ciência aborda questões sobre o mundo natural e material (NGSS 2013b, p.3)

Primeiramente, a despeito das possíveis consequências práticas de tal lista, salienta-se que os pontos acima são tão discutíveis filosoficamente quanto as listas de VCNdC de Lederman e McComas. Entretanto, embora as possíveis fragilidades conceituais e filosóficas com a matriz acima, há uma problemática adicional - não se trata mais de uma proposta advinda de um grupo de pesquisadores, mas sim de um documento curricular afinado na lógica neoliberal com efeitos coercitivos e sociais enquanto política curricular. Como comparação, as Diretrizes Curriculares Brasileiras (Brasil 2013), no que lhe competiria citar discussões na área de pesquisa de ensino de ciências sobre $\mathrm{NdC}$, não o faz explicitamente, ainda que seja possível identificar concepções de NdC no texto utilizando técnicas básicas de análise de discurso (Noronha 2016). A presença de uma lista similar àquela da VCNdC no NGSS - especialmente no que diz respeito à sua forma - faz com que seus defensores transportem a autoridade conferida ao documento curricular à visão consensual, impondo o discurso de que ela é “consistente com o que os atuais documentos de reforma curricular dizem do que estudantes devem saber sobre NdC” (Lederman \& Lederman 2014a).

Não parece ser um exagero afirmar que este é um período singular no percurso histórico das pesquisas sobre NdC no EC. A (aparente) maior atenção de elaboradores de currículos para com a NdC em políticas públicas educacionais pode ser entendida como uma conquista da área de pesquisa em EC, uma vez que essa inclusão resultou em parte 
da pressão de pesquisadores da área ao longo dos últimos anos - ainda que, neste episódio específico da implementação da NdC no NGSS, segundo McComas e Nouri (2016), essa conquista tenha se mostrado relativamente frustrante. Em tal mescla de frustração e satisfação, McComas e Nouri (ibid. p.20) projetam:

Nós agora precisamos de currículos ricos em NdC para guiar a instrução e políticas de testes do tipo avaliações de fim de curso contendo NdC, para assim encorajar professores a incluir esse conteúdo em suas aulas.

Para Lederman e Lederman (2014b, p.237), parte da frustração se manifesta no ‘agnosticismo pedagógico’ do documento, por não prover recomendações explícitas de como os professores deveriam ensinar $\mathrm{NdC}$ e como deveriam avaliar as concepções dos estudantes. No mesmo sentido de que McComas e Nouri na última citação, Lederman e Lederman (idem) afirmam:

Defensores [da inclusão da NdC no EC] dirão que a NdC é contemplada no NGSS. No entanto, como formadores de professores, sabemos que a simples inclusão da $\operatorname{NdC~(...)~não~é~suficiente.~Precisamos~fornecer~aos~nossos~}$ professores, em formação e também para aqueles em serviço, guias para encontrar as conexões da $\mathrm{NdC}$ às dimensões explicitamente especificadas no NGSS. Em seguida, precisamos possibilitar o desenvolvimento profissional que permitirá aos professores incorporar com sucesso a NdC em suas instruções científicas de forma explícita e reflexiva.

Dado o peso destes autores para a HFC e NdC no EC, a citação acima tem importância central a esta seção. Tanto pela iminência de seus anseios (pelo menos, em um primeiro momento, nos Estados Unidos), pela influência destes autores sobre aquelas áreas de pesquisa, e, finalmente, pelo aparente desconhecimento (ou negligência) destes autores sobre inúmeros trabalhos críticos de teóricos de currículo às políticas de testes padronizados atuais - os ‘guias’ que Lederman e Lederman (2014b) não explicitaram. É preciso considerar com atenção os novos problemas que podem advir (ou, que já começam a se manifestar) nessa nova etapa. Como advogaremos abaixo, se faz necessária e urgente uma visão crítica sobre políticas pautadas na lógica de testes padronizados e, consequentemente, sobre o papel da NdC nestes.

Importa enfatizar que já nos dias atuais, a presença de elementos de NdC e HFC em avaliações nacionais e internacionais não é, em definitivo, um fenômeno raro - um exemplo é o quantificador Programme for International Student Assessment (PISA) 
(OECD, 2013; 2014). No Brasil, houve um crescimento (ainda que tímido) da presença de questões envolvendo HFC no ENEM (Exame Nacional do Ensino Médio) nos últimos dez anos (Spolidoro \& Reis 2017). Os vestibulares nacionais para ingresso em instituições públicas, embora diversos, raramente apresentaram no passado questões históricas ou filosóficas sobre a ciência. Com efeito, como exemplificação, os candidatos do vestibular FUVEST 2014 deparam com a seguinte (e única) questão de conteúdo de HC na primeira fase eliminatória ${ }^{34}$ :

O desenvolvimento de teorias científicas, geralmente, tem forte relação com contextos políticos, econômicos, sociais e culturais mais amplos. A evolução dos conceitos básicos da Termodinâmica ocorre principalmente no contexto
a) da Idade Média.
b) das grandes navegações.
c) da Revolução Industrial.
d) do período entre as duas grandes guerras mundiais.
e) da Segunda Guerra Mundial.

Como apontam Forato e Guerra (2014, p.137), tal questão foi uma surpresa considerando o histórico deste vestibular, no qual não é raro conter enunciados com nomes de cientistas, experimentos históricos, entre outros. É compreensível que a menção explicita de que a ciência 'tem forte relação com contextos políticos, econômicos, sociais e culturais mais amplos' - por sua proximidade a antigas bandeiras defendidas na área de pesquisa de HFC no EC - inspire a comemoração. Contudo, ainda que isto aparente algo celebrável - dado o esforço ao longo de anos de pesquisadores da área em aproximar a HC ao EC -, faz-se necessários dois breves comentários tendo em vista tanto o conteúdo conceitual (do tema específico desta questão em si) e sua relação estrutural com a atual conjuntura das políticas educacionais.

Um primeiro ponto de análise - que tinha como alternativa correta pelo exame o item C-, é o seu próprio conteúdo histórico. A primeira frase do enunciado reflete um flerte sobre historiografias da ciência mais recentes, e dificilmente seria objeto de desacordo entre historiadores da ciência contemporâneos. Entretanto, pode-se entender que elemento mais discutível é a concepção de 'revolução industrial' provavelmente subentendida na formulação desta questão. Como se sabe, o conceito de 'revolução científica', tendo sido bastante popularizada pela obra de Kuhn (1997) The Structure of Scientific Revolutions

\footnotetext{
${ }^{34}$ Disponível em http://acervo.fuvest.br/fuvest/2014/, acesso janeiro de 2017.
} 
em 1962, foi e é bastante importante na $\mathrm{HC}^{35}$. Todavia, críticas surgiram quanto à noção teleológica de uma suposta estrutura em mudanças ou revoluções científicas (McGuire \& Tuchanska 2013, p.168), assim como à imprecisão no significado do termo 'paradigma' na obra, com o próprio Kuhn reconheceu (Condé 2017, p.91). Por outro lado, o rupturismo-descontinuismo sugerido pela teoria kuhniana - o qual fomentou formas exageradas de socioconstrutivismo e relativismos (ibid., p.86)-, com o amadurecimento da historiografia da ciência mostrou-se insustentável (ver Shapin 1996; Heilbron 2013) ${ }^{36}$. Com efeito, para a HC a 'revolução industrial' não precisa ser necessariamente entendida como uma forte descontinuidade localizada entre os séculos XVIII e XIX ${ }^{37}$, mas também como um longuíssimo, gradual e contínuo processo (não linear) com manifestações que remontam ao desenvolvimento de técnicas e ferramentas pré-industriais ligadas a culturas materiais locais e manufatureiras já no fim da Idade Média e também às políticas econômicas (pré-capitalistas) nos impérios coloniais desde o século XVI (Landes 1969, p.42; Magalhães 2018, p.239). Ainda que seja compreensível associar o desenvolvimento da Termodinâmica com a 'revolução industrial' e suas máquinas térmicas - ‘extensões do homem’ como argumentou Bernal (1971) -, é preciso ter em mente que a criação dos primeiros protótipos teóricos de máquina a vapor deu-se já no fim do século XVI (Usher 1988, p.375), e que a teoria ondulatória do calor e do calórico foram, de um ponto vista histórico, tão importantes quanto própria a formulação matemática das leis da termodinâmica no século XIX ${ }^{38}$.

\footnotetext{
${ }^{35}$ Como também é sabido, o impacto da obra de Kuhn também foi sentido na área de pesquisa EC anos depois (ver Ostermann 1996), tornando-se uma enorme influência.

${ }^{36}$ Como comenta Fara (2014, p.222), o conceito de 'revolução científica', nos moldes kuhnianos, está hoje fora de moda entre pesquisadores da área de HFC - o que não oculta o fato de, como bem lembra a historiadora, que muitos têm dificuldade em "abandonar uma forma tão conveniente e familiar de estruturar o passado".

${ }^{37}$ A ideia de contestar o conceito histórico de 'revolução industrial' visa criticar a noção de uma repentina ou súbita mudança em circunstâncias sociais, econômicas e materiais no século XIX (e, em especial, na Grã-Bretanha) sem considerar apropriadamente as condições sociais, econômicas, culturais e materiais de longa data que 'prepararam o terreno' (Landes 1969). Importa salientar que tal contestação que nos referimos não remete às teses de historiadores econômicos de veia (neo)liberal que acusam historiadores marxistas de ‘contaminarem’ a história e a historiografia de revoluções (ver Hartwell 1990).

${ }^{38}$ Dentro desta forma de ver a 'revolução industrial' e também a termodinâmica como processos longos, não necessariamente lineares, cheios de tensões dialéticas de rupturas-continuidades, uma possível contribuição para a 'história longa' da termodinâmica foi, entendemos, ainda insuficiente explorada. Tratase do que estudos antropológicos apontam sobre o (antiquíssimo) desenvolvimento práticas culinárias e o conhecimento tácito-técnico sobre cozimento de alimentos. French (2008, p.352), num esforço admirável de 'recuperar' a história das mulheres, comenta como o confinamento (opressivo) de mulheres nas cozinhas, especificamente no contexto europeu rural dos séculos XVII a XVIII, culminou na intensa evolução de técnicas culinárias tácitas envolvendo cozimento e vapor (assim como o cultivo de alimentos, a prospecção doméstica-alimentar para sobrevivência no inverno, entre outras). Embora esta 'história esquecida' seja de fato muito menos lembrada que outras - como aquela envolvendo o francês Denis Papin e a invenção da marmita de pressão a vapor (antecessor da panela de pressão) em 1679 -, ela há de ser fundamental para
} 
Como segundo ponto de análise - e, talvez o mais grave considerando a problemática discutida na seção anterior-, temos a postura de estudantes frente à questão especificada. Adiantando apontamentos, tem-se que é fato conhecido que os vestibulares (em especial para ingresso em instituições públicas) constituem-se uma enorme fonte de pressão para estudantes em geral (e também a professores) - o que não raro leva uma postura altamente pragmática e mecanizada frente às questões destes testes. Tal postura é 'aprendida' em aulas também pragmáticas e mecanizadas, ministradas por professores cuja estabilidade de trabalho (particularmente em escolas privadas) muitas vezes depende de 'resultados'. Técnicas de memorização e mnemônicas (na forma de frases, analogias, canções, entre outros) tendem a ser enfatizadas mais do que qualquer outra metodologia ou objetivo educacional. Portanto, é razoável o raciocínio de que, nesta trilha, a HC, tornando-se mais frequente em vestibulares, não terá 'tratamento especial' - os estudantes, pressionados, provavelmente irão memorizar conteúdos de HFC, utilizar recursos mnemônicos, entre outros 'rituais'.

Se a tão almejada aproximação histórico-filosófica ao EC é defendida por auxiliar na formação de cidadãos críticos e atuantes, além de potencialmente fornecer uma visão mais rica e menos deturpada da ciência - objetivos em comum em muitas abordagens no EC (Aikenhead 2006) -, é preciso analisar com mais paciência as consequências de sua presença em testes, vestibulares e outros dentro de lógicas neoliberais. Num contexto não exatamente hipotético, como discutiremos abaixo- em que avaliações de proficiência padronizadas centralizadas em larga escala ${ }^{39}$ condicionem ou restrinjam a autonomia de professores, estudantes e os próprios currículos, a HFC - adaptada para memorização e mnemônica -, na prática, funcionará como mais um dente da engrenagem no processo de mercantilização da educação. Por isso, a luta por uma formação crítica via HC não deve passar pela celebração passiva de sua presença em testes padronizados ou vestibulares e, analogamente, tampouco devemos ser ingênuos em pensar que a grande incidência de concepções inadequadas sobre ciência será resolvida pela presença da VCNdC em avaliações desta natureza.

\footnotetext{
uma 'história longa’ contextual da termodinâmica, envolvendo não só propriamente a criação de máquinas térmicas e a formulação das leis matemáticas formalizadas, mas também as técnicas e conhecimentos tácitos (cotidianos e laboratoriais) que pavimentaram ao longo dos séculos o caminho para estas. Assim, é justo dizer que o (longo) desenvolvimento da termodinâmica até o século XIX, completando Bernal, contou com as 'extensões das mulheres' (em contextos de confinamento familiar e opressão, é preciso lembrar) as 'máquinas silenciosas' de cozimento a vapor.

${ }^{39}$ Devido à extensão deste termo, usaremos a partir deste ponto do texto um referente mais curto testes padronizados.
} 
Os apontamentos desta seção procuram justificar porque o apelo de McComas e Nouri (2016, p.20) pela presença da NdC em testes padronizados para "encorajar professores a incluir esse conteúdo em suas aulas” é, na verdade, muito grave. De um ponto de vista crítico, tal apelo é mais uma carta branca para 'políticas de incentivo’ que podem desembocar em medidas controle e constrangimento - isto é, em 'políticas de punição' sobre estudantes, professores e escolas (Castro 2009, p14). De um ponto de vista conceitual, o conteúdo da NdC ‘adaptado’ para os testes podem estar bem aquém daquele idealizado por pesquisadores da área, a apresentação na forma de tenets pode se tornar 'oficial', o que deve tornar mais frequente questões de vestibulares como a discutida no início da seção. De um ponto de vista de dentro das salas de aula, os passos anteriores hão de moldar o caminho para a NdC, ao lado de outros conhecimentos escolares, em direção ao fenômeno 'teaching to test' alertado pro Au (2011). Enfim, grande parte (senão toda ela) dos esforços de pesquisadores da área de EC, ao longo de vários anos, pela aproximação da HFC em defesa de visões mais adequadas sobre ciência e de uma educação crítica, podem então se tornar frustrados.

Outro motivo do apelo de McComas e Nouri ser grave reside no fato de que grande parte dos testes padronizados existentes, desde a escolha de seus indicadores (Iaes apud Bauer, Alavarse \& Portela 2015, p.1375) até os processos de suas implementações, refletem - algo já anunciado nesta e em seções anteriores - aquilo que diversos autores, entre eles Apple (2004), chamam de ideologia neoliberal. Esta está geralmente vinculada a ideários de 'liberdade individual', ‘esforço individual', 'mérito' - na educação ela é o núcleo da visão economicista, como foi arguido anteriormente -, e também a um cientificismo identificado por Au (2013) inerente à lógica de testes padronizados. Assim, a ideologia cientificista, uma já antiga, persistente e tão combatida adversidade no EC (Désautels 2015), principalmente na perspectiva filosófica no que tange concepções sobre ciência, se faz presente também politicamente.

Conforme exploraremos na seção seguinte, Apple (2004) chamou de 'visão positivista' em Ideologia e Currículo algo que reflete uma espécie de associação entre as ideologias neoliberal e cientificista - responsáveis por naturalizar visões de sociedade e ciência sem conflitos. Argumentaremos que não é um acidente a alta reincidência de concepções inadequadas sobre ciência entre estudantes e professores, apesar do árduo esforço de pesquisadores, professores e também dos próprios estudantes em numerosas pesquisas, treinamentos, levantamentos, entre outros. A ideologia cientificista, tão enraizada socialmente quanto à ideologia neoliberal nos tempos atuais - seja na mídia escrita e 
digital, telejornais, obras de divulgação, entre outros -, estaria nas origens de uma fração significativa destas ocorrências, conforme teorizaremos, e que reforça a importância de combatê-la. Todavia, conforme argumentaremos na seção seguinte, não se combate uma (ideologia cientificista) sem se combater também a outra (ideologia neoliberal) - e, por isso, uma concepção crítica de ciência envolve necessariamente uma concepção crítica de sociedade (e, por transitividade, uma concepção crítica de educação).

Este é um momento em que o tão repetido contra-argumento de Lederman de que os debates sobre o conteúdo da NdC são ‘inúteis’ - ou, de que não é importante definir com rigor histórico e filosófico a $\mathrm{NdC}$, mas sim "o que dela é especificado a estudantes saberem” (isto é, a partir de documentos como o NGSS) (Lederman \& Lederman 2014a) - pode parecer razoável, mas por motivos diferentes daqueles que o autor elencou. É devido à associação entre as ideologias mencionada que a reconceitualização da $\mathrm{NdC}$ não é uma tarefa 'inútil', se entendermos que este urgente e necessário exercício não visa apenas o refinamento histórico e filosófico, mas sim uma objetivação política e social.

\subsection{Ideologia e cientificismo - ou, a ciência abduzida pelo capital}

“Eu ainda falo sobre ideologia (...). Talvez por causa disso eu seja um dinossauro (...), mas eu acho muito difícil entender a sociedade contemporânea e práticas sociais abrindo mão [dela]” (Hall apud Grossberg 1986, p.48). Esta curta afirmação de Stuart Hall - em tom defensivo frente a uma acusação de correntes pós-modernas de que este tema é 'ultrapassado'-, reflete a insistente importância do conceito de ideologia mesmo em tempos em que 'tudo’ é 'descontruído’ (Hall 2000, p.24). Com efeito, o conceito de ideologia foi e ainda é largamente estudado e na educação ocupa um lugar central em teorias críticas de currículo (Apple 2004). As concepções de origem marxista tem proeminência e representam um dos legados do marxismo, ainda que continuamente revisitadas, criticadas e reformuladas (ver Boucher 2015) - muita embora, como atenta Hall (2000, p.26), Marx e Engels não tenham desenvolvido uma teoria de ideologia propriamente dita, o que é evidenciado na flutuação dos significados adotados pelos autores sobre o conceito. Por outro lado, elas foram alvo de apropriações torpes e frágeis. Em particular, passada a primeira década do século XXI e levando em conta o que pode 
ser chamado de 'onda conservadora' brasileira, o atual contexto educacional é um palco particular de banalizações conceituais de ideologia, como exemplificaremos abaixo.

Como alertado por diversos autores (Ação Educativa 2016), o movimento EsP agrega simpatizantes que contribuem para esta vulgarização, como pode-se averiguar em uma página específica de seu sítio virtual na qual atacam Paulo Freire:

Na prática, a coisa funciona assim: o professor questiona os alunos sobre o seu dia a dia, apresenta uma explicação ideológica para os problemas e insatisfações relatados, e depois discute com eles o que acharam desse conteúdo. Se os alunos discordarem da explicação, o professor argumenta em favor do seu próprio ponto de vista ideológico. Ao fim do diálogo, o professor conclui que os alunos que ele conseguiu convencer estão agora "conscientes" da sua "verdadeira” condição de oprimidos e explorados pela sociedade de classes. (.) Ora, isso é apenas a dita “educação bancária” camuflada de diálogo! O professor apresenta uma única via para explicar as situações relatadas pelos alunos: a ideologia em que ele acredita. O aluno é deixado na ignorância sobre a existência de pesquisas que explicam as situações de pobreza, desigualdade, problemas urbanos e ambientais, entre outros, fora do universo teórico e ideológico do professor ${ }^{40}$.

O uso repetido das palavras ‘ideologia’ e ‘ideológica (o)’ acima reflete um exemplo da confusão frequente entre ideologia e ideário - este sendo um conjunto de ideias que pode ser sistemático e encadeado (Chaui 2008, p.7). No caso, o autor do texto da citação se referia ao ideário marxista ou marxiniano, dado a apropriação particular deste por Paulo Freire. Tal banalização subtrai referentes historicamente dados por autores de veia marxista, suas naturezas histórica, política e social - e, principalmente, sua relação com a ocultação de mecanismos de desigualdade social e dominação político-econômica (idem).

A razão de ser do conceito de ideologia no contexto de Marx envolve o escrutínio que parte da alienação do humano às condições de exploração e desigualdade nas quais se encontra, a quem esta 'realidade' lhe aparece como 'natural' (Chaui 2008, p.57). A ideologia, sendo um processo objetivo porque enraizado nas condições de vivência social dos indivíduos, cria 'falsas consciências' - termo mais próximo ao marxismo ortodoxo do que a correntes pós-marxistas - de que as classes sociais são uma 'coisa em si' (a-

\footnotetext{
${ }^{40}$ Disponível em http://www.escolasempartido.org/artigos-top/382-paulo-freire-e-a-educacao-bancariaideologizada. O autor é o geógrafo Luiz Lopes Diniz Filho, professor da Universidade Federal do Paraná. Acesso janeiro de 2018.
} 
histórica, fatalista), ou, que a pobreza é resultado da 'preguiça individual' ${ }^{41}$ (ibid., p.73). Seu poder se verifica à medida em que consegue ocultar as origens históricas e sociais da divisão em classes e a constante luta entre esses (ibid., p.82). Não é 'arquitetada', mas emerge da atividade social humana e traduz-se no processo em que o ideário da classe dominante torna-se o ideário de todas as classes - as conhecidas colocações de Marx em A Ideologia Alemã de que a consciência está diretamente ligada às condições materiais de produção e que "as ideias da classe dominante são, em cada época, as ideias dominantes” (apud ibid., p.85) sintetizam este ponto.

Nas palavras de Chauí (ibid., p.94), trata-se ideologia de uma "ilusão, necessária à dominação de classe”, ou ainda:

(...) um conjunto lógico, sistemático e coerente de representações (ideias e valores) e de normas ou regras (de conduta) que indicam e prescrevem aos membros da sociedade o que devem pensar e como devem pensar; o que devem valorizar e como devem valorizar, o que devem sentir e como devem sentir, o que devem fazer e como devem fazer. Ela é, portanto, um corpo explicativo (representações) jurídico (normas, regras, preceitos) de caráter prescritivo, normativo, regulador, cuja função é dar aos membros de uma sociedade dividida em classes uma explicação racional para as diferenças sociais, políticas e culturais, sem jamais atribuir tais diferenças à divisão da sociedade em classes a partir das divisões na esfera da produção. (ibid., p.109)

Com algum cuidado, pode-se afirmar que uma concepção nuclear de ideologia envolve ou implica em algum nível um 'ocultamento da realidade', processos de dominação e a subordinação de uma parcela da sociedade a outra. Tais características são mais ou menos compartilhadas (salvo inevitáveis particularidades) por diferentes autores de inspiração marxista (ver Althusser 1984; Eagleton 2013; Zizek 1994). Todavia, o peso de sua conceitualização se faz valer em articulação com outros que apreendem as complexidades da sociedade - neste sentido, a riqueza da diversidade de concepções críticas de ideologia é notável (Magalhães 2016).

Naturalmente, o conceito de ideologia não foi (e não é) imune ao desenvolvimento histórico e diversificação de teorias de orientação marxista e outras correntes. Com efeito, no contexto particular de Marx e Engels, a acepção de ideologia como 'falsa consciência' ou fazia-se como arma ao combate ao hegelianismo idealista - os ‘jovens hegelianos’ -, à

\footnotetext{
${ }^{41}$ Este foi exatamente o ponto do filósofo liberal britânico John Locke, ao afirmar categoricamente que “o crescimento do número de pobres (...) nada mais é do que o relaxamento da disciplina e a corrupção dos hábitos” (apud Mészáros 2006, p.39).
} 
religião e ao pensamento antimaterialista que fundava a dominância burguesa (Hall 2000, p.27). Como aponta Hall, tal acepção não foge a crítica acerca de sua vacuidade em explicar porque alguém vivendo uma ‘falsa consciência’ não a percebe falsa, tampouco e porque alguém a percebe - além disso, ela retrata tanto os 'dominadores' como os 'dominados' como agentes passivos (ibid., p.31). Assim posto, o que chamamos de concepção nuclear pode se mostrar bastante frágil do ponto de vista epistemológico, por sugerir em contraposição à existência de um 'falsa consciência' do mundo uma forma absolutamente 'correta' de ver o mundo (ibid., p.106). Contudo, essa sugestão não é absolutamente necessária ou inevitável. Retomaremos a este ponto ao final desta seção.

Para Apple, enquanto neomarxista, o conceito de ideologia é central à educação, assim como o conceito de 'hegemonia' de Gramsci (Gandin \& Lima 2016) - ainda que deliberadamente venha a cometer 'heresias' na interpretação devido a especificidades do contexto educacional. Em suas palavras (Apple 2000, p.15), a ideologia simplesmente "está aí" - e faz-se valer vivendo no senso comum das pessoas e em seus cotidianos. Por sua vez, o senso comum é uma arena de batalha, está em constante movimento - isto é, um processo -, o que implica a 'necessidade’ de contínuos esforços para deixá-la onde 'deveria' estar - trabalho este empregado pela hegemonia, que visa que a "sustentação do modo capitalista de produção seja entendida como algo da vida cotidiana, como algo necessário ou natural” (Gandin \& Lima 2016, p.658). Neste sentido, hegemonia é (também) um processo, nunca um estado de coisas ou 'projeto concluído', como aponta Hall (2011, p.26). Para Apple, a hegemonia, sendo política e também cultural, não é espontânea no sentido dado por Gramsci (Au \& Apple 2009, p.85) - ainda, não se impõe, mas invade a vivência humana, satura as consciências fazendo com que "forma como se vê e se interage com o mundo (...) bem como as interpretações que se faz através do senso comum, tornem-se a única maneira possível de compreender o mundo" (Gandin \& Lima 2016, p.658). É oportuna a menção ainda que breve a algumas outras características da hegemonia ideológica.

Uma característica curiosa, que está presente na citação apresentada acima, retirada do site do movimento EsP, é o uso de discursos individualistas e 'pluralistas'. A fachada de 'apresentar diferentes visões', supostamente indo ao encontro de ideais democráticos, é utilizada ideologicamente numa apologética contra visões críticas à hegemonia, acusadas por sua vez de 'não-pluralistas' (Mészáros 2005, p.175). Com efeito, como afirma categoricamente Mészáros (ibid., p.5), não raro visões críticas (que o autor chama de ‘esquerda') são ideologicamente tachadas de ‘dogmáticas’ ou 'fanáticas’, enquanto que o 
rótulo de partida de visões conservadoras (que o autor chama de 'direita’) é 'moderado'. 'Ditadura do proletariado' e ‘ditadura comunista’ (ou ‘socialista') são dois exemplos de rótulos - utilizados ostensivamente por membros do movimento EsP (ver Ação Educativa 2016) - de associação do marxismo ao totalitarismo (Boucher 2015, p.13). Tal tipo de 'pluralismo' ideológico - que pode até ser plural de fato em alguns sentidos, porém, contendo apenas visões aquiescentes à hegemonia- é falso, pois além de mascarar a realidade (com um subterfugio apenas aparentemente democrático), exclui possibilidade moral de ser legitimamente contestado (Mészáros 2005, p.175).

A retórica ideológica de 'neutralidade ideológica’ também merece menção. Consiste na defesa de que se adota uma postura 'objetiva' e 'ideologicamente neutra', com base em critérios 'auto evidentes’, o que forneceria álibi para desmerecer completamente ‘ideologias’ (isto é, o que se entende como ideologias, melhor palavra seria ideários), não importando quão forte suas evidências teóricas e empíricas são (Mészáros 2005, p.4). Apple (2001, p.107) também identifica esta 'poderosa técnica' de assumir a priori que os argumentos adversários não são genuínos, e, portanto, inverdades. Não raro, tal postura agrega a estratégia de usar insultos como ‘evidência’ como exemplifica Mészáros citando o comentário de Keynes sobre a 'doutrina’ marxista: “É difícil para um filho da Europa ocidental, educado, decente e inteligente, encontrar seus ideais aqui [no marxismo], a não ser que ele tenha primeiro sofrido um processo estranho e horrível de conversão que mudou todos os seus valores” (apud Mészáros 2005, p.6).

Aos objetivos deste trabalho serão oportunas as concepções de Chauí (2017, p.56) e de outros autores acerca de uma ideologia específica, que chamamos como Apple (2004) de ideologia neoliberal - sobretudo por sua forte relação à ideia de meritocracia. Em seções anteriores esboçamos panoramicamente algumas de suas características, em especial a sua relação aos processos de mercantilização e privatização da educação - em suma, tais processos carregam uma ideologia (neoliberal) que as naturaliza (Ball 2004, p.4). Por sinal, esta é a mesma que naturaliza que o que é público é (naturalmente) 'ruim' e o que é privado é (naturalmente) 'bom’ (Apple 2005, p.41), que concebe o amparo estatal sobre instituições públicas escolares e de saúde como 'gastos' (Lustig 2015, p,15), que as 'soluções mercadológicas' na educação - traduzidas, por exemplo, em políticas educacionais que incentivam a competição - são as soluções para melhorar a educação (Apple 2001, p.108). De fato, a já mencionada visão economicista de educação - que se manifesta desde os reformadores empresariais até as acepções populares de que 
'educação é apenas treinamento para conseguir um emprego’, ou de que ‘educação é uma corrida (competitiva)’ (Karpov 2013, p.30) - tem suas raízes na ideologia neoliberal.

Os efeitos ideológicos liberais e neoliberais sobre a educação têm sido identificados, estudados e combatidos há anos. Uma referência histórica relevante e bastante influente é Althusser (1984) - embora atualmente 'fora de moda', nas palavras de Hall (Grossberg 1986, p.58). De forma sintética, Althusser acusava que o papel das escolas enquanto aparato ideológico seria o de ensinar o 'know-how' e o 'bom comportamento' que os estudantes futuramente usariam em seus serviços ‘destinados’ (Althusser 1984, p.6). Dito de outra forma, a escola garantiria a injeção e a sujeição dos estudantes à ideologia dominante (ibid., p.7). O aparato ideológico educacional - no movimento de não se revelar, de ocultar não só a realidade, mas a si mesma (Chaui 2008) - representa a escola como um ambiente neutro, 'livre de ideologias' (Althusser 1984, p.30). Este parece ser exatamente o ponto de alguns autores contemporâneos que, na suposta 'empreitada neutra’ rumo à melhora da educação, defendem que se 'proteja' a escola de “assédios ideológicos” (Schwartzman 2015, p.18) ou que a livre de “ideologias pedagógicas" (Schwartzman 2016, p.192). Para Althusser (1984, p.31), mesmo a minoria de professoras e professores que ensinam contra a ideologia - que ele chama de 'heroínas' ou 'heróis' não consegue desviar a escola de sua função para reprodução das desigualdades sociais.

A despeito do reprodutivismo total althusseriano, cuja carga de pessimismo abala ideais progressistas, Apple e outros autores foram bastante influenciados, em especial na conceitualização de aparato ideológico e com a reflexão sobre os papeis da escola à acumulação de capital (cultural) e à legitimação meritocrática (Apple 1989, p.31). Contudo, a noção mecanicista de reprodução foi revisitada, no sentido de que se tornou inviável conceber as escolas como 'puramente injetoras de ideologias exógenas'. Estas, Apple e outros alegaram, se originam também nos contextos de sala aula - e os estudantes, teorizou Apple em Educação e Poder (1989, p.41), têm poder para sustentar a reprodução ou resisti-la. Assim, a ideologia não se conceberia mais como algo 'imposto' aos estudantes pela hegemonia, mas como uma "parte de uma cultura vivida que é o resultado das condições materiais de nossas práticas cotidianas”, que “contém tanto elementos de bom senso quanto elementos reprodutivos” (ibid., p.42). A força da ideologia nas escolas não estaria na sua imposição de fora para dentro, mas na sua acomodação em tais práticas.

Os fronts de ação da hegemonia ideológica, no seu contínuo escrutínio em manter-se hegemônico, incluem, segundo Freitas (2016, p.140), o controle da 'gestão escolar' e 
também o processo escolar formativo - isto é, os objetivos, métodos e conteúdos -, no intuito de alinhá-los às necessidades produtivas. O controle da 'gestão escolar' se daria idealmente pela iniciativa privada, 'mais eficaz', ancorada em políticas de responsabilização, premiação-punição, avaliações (e divulgações) sistemáticas e outras (idem), como discutido em seções anteriores. Outro front é a desvalorização da profissão docente - que se dá seja por meio da precarização da carreira e dos ambientes de trabalho, do apelo ao crescimento de regimes de contratos temporários "criados ou fechados de acordo com a demanda do mercado de trabalho" (Schwartzman 2016, p.198), do condicionamento de suas ações por “deverem ser responsabilizados por resultados avaliativos específicos” (Jimenez, King \& Tan 2012, p.14), da crescente influência de setores privados nos currículos de formação universitária (entre eles os das licenciaturas) por "não prepararem para o mundo do trabalho" (Riad 2017, p.18), entre outros. Dessarte, o papel do professor no quadro da ideologia neoliberal é o de alguém "subordinado e escrutinizado por princípios de mercado, dedicado a apaziguar politicamente e socialmente frações da classe trabalhadora inseridas no sistema de educação pública” (Leher 2016, p.xiii). Ou, de alguém a ser ‘dominado’, outra faceta da natureza ideológica da desvalorização da profissão docente clara na análise de Apple especificamente no contexto estadunidense. A saber, de que a desvalorização da profissão docente estaria diretamente relacionada com a maior presença feminina. Como resumem Gandin e Lima (2016, p.660):

Apple (...) mostra em seus estudos que, à medida que o trabalho docente passou a se caracterizar como feminino, “criou-se um pressuposto" de que seria necessário maior controle desse trabalho. Isso decorreu principalmente da ideia, amplamente reforçada por grupos conservadores, de que as mulheres são menos qualificadas que os homens para trabalharem com os conteúdos escolares das ciências e que, portanto, precisam ser mais controladas para que façam o trabalho antes realizado pelo sexo masculino. A própria ocupação - no caso, a de professora - passa a ser entendida como pouco qualificada. (...) Em relação às políticas curriculares padronizadas, por exemplo, Apple (...) afirma que tal política encontra espaço porque existe uma desconfiança em relação ao trabalho realizado por mulheres, como se elas são fossem tão boas quanto os homens. Assim, ter um currículo padronizado representaria uma garantia de que estas professoras realizariam um bom trabalho apesar de serem mulheres. 
Cabe citar também como front da hegemonia ideológica a manobra já mencionada de certo pseudo-altruísmo neoliberal, no sentido de 'salvar' os mais pobres através de uma melhor inserção no mercado (Acciolly, Gawryszewski \& Nascimento 2016, p.33). Entendida a reforma neoliberal como a solução à educação, elaboradores de políticas públicas alinhados com reformadores empresariais veem espaço para argumentar pelo ceticismo da melhora da educação por mais investimentos públicos (Schwartzman 2015, p.7), pelo descrédito a políticas afirmativas por serem ineficientes ou ferirem o "mérito individual” (Apple 1999, p.13), pela expansão das instituições privadas (muitas vezes custeadas por fundos públicos) (Jimenez, King \& Tan 2012, p.14), e até mesmo contra sindicatos e movimentos sociais por 'atrasarem' ou 'bloquearem mudanças modernizadoras' (Castro 2011, p.12). Assim, o discurso de que o papel fundamental (ou exclusivo) da educação é formar para o trabalho ganha força - em cadeia, os currículos são atacados por serem sobrecarregados de ‘conteúdos inúteis para o futuro' e por 'falta de escolha' (Castro \& Fini 2008, p.94), e, principalmente por suas insuficiências quanto a possibilidades de formação técnica-profissional em função das “demandas do mercado de trabalho" (Schwartzman 2016, p.184).

Em contraste à defesa recorrente de que os problemas educacionais se resumem a 'gestões ineficientes', a reforma neoliberal da educação (em um sentido mais amplo), envolvendo os processos de mercantilização e privatização da educação e seus corolários (entre os quais aqueles discutidos nesta e em seções anteriores), não se resume (ou, não tem se resumido) verdadeiramente a uma mera 'mudança de administração' ou de 'filosofia'. Como atesta Ball (2004, p.24-5) isto:

(...) envolve mudanças na experiência educacional, o que significa ser um professor e um estudante. Isso muda quem nós somos e nossa relação com o que fazemos, pervadindo sobre todos os aspectos de nossas práticas e pensamentos cotidianos - sobre os modos como nós pensamos sobre nós mesmos e nossas relações com os outros, mesmo nossas relações sociais mais próximas. Isso está mudando o quadro de possibilidades no qual nós agimos. Isso não é apenas um processo de reforma, é um processo de transformação social. Sem algum reconhecimento e atenção no debate público sobre o insidioso trabalho que está sendo feito, nesses aspectos, pela privatização e mercantilização - podemos nos encontrar vivendo e trabalhando em um mundo composto de contingências, dentro das quais as possibilidades de autenticidade e os significados de ensino, aprendizagem e pesquisa sejam gradualmente e inexoravelmente apagados. 
Por sinal, tal mudança não impacta somente o ensino básico, mas também o ensino superior e a pesquisa, como discutido em seções anteriores. Com razão, Apple (1993, p.313) temia que a mercantilização também do conhecimento nas universidades acabasse por se tornar tão 'natural' que, futuramente, os estudantes não poderão ver nada de errado nisso. No que tange a mercantilização da ciência, este temor é justificável uma vez que para o crescente número de financiadores deste processo tem-se apenas o que celebrar (Oliveira 2013, p.2473). Isto é problemático, entre outros motivos, por deslocar a pesquisa científica de interesses epistêmicos e/ou públicos - em geral não obrigatoriamente lucrativos e inovadores, destinados ao bem estar público como temas ambientais e estudos de impacto ${ }^{42}$ - exclusivamente para interesses privados - que tendem a visar fundamentalmente o lucro (ibid., p.2474). Tal deslocamento está na raiz das acusações de que a ciência ‘não dá lucro’ ou de que investir nela é ‘mal negócio' - pois os ‘custos’ e 'riscos’ são medidos em função do 'retorno do investimento' na forma de lucro (ibid., p.2481), algo em geral não alcançado quando a pesquisa é mais deslocada ao interesse público. Por outro lado, tal deslocamento acaba também por reforçar a naturalização da 'ciência neoliberal' (Oliveira 2013), e de sua suposta natureza 'nãoideológica', 'neutra', ‘despreocupada', entre outros. Isto seria o motivo, segundo Mészáros (2005, p.199), da preocupação com valores sociais e a responsabilidade social da ciência pelos cientistas ser em geral individualizada (raramente institucionalizada) e de ‘segunda mão’ - isto é, manifesto fora do ambiente de trabalho propriamente científico.

O empreendimento científico, como outros empreendimentos humanos, foi raptado pela lógica capitalista - ademais, como coloca Mészáros (2005, p.197), também contribuiu historicamente para o fortalecimento desta lógica, relevando suas potencialidades positivas e destrutivas. Em outras palavras, a ciência (juntamente à tecnologia) tornou-se agente do capital - dir-se-ia que a última está a serviço desta -, de modo que uma faceta do "poder dos capitalistas encontra-se no monopólio dos conhecimentos e da informação" (Chaui 2017, p.56). A intensificação desta "relação de servidão’ pode ser historicamente localizada no contexto do Iluminismo nos séculos XVIII e XIX. Mészáros (2005, p.178) aponta como a crescente desigualdade social no contexto europeu foi entendida por iluministas como fenômeno transiente, que haveria de ser inevitavelmente sanado pelo avanço do conhecimento científico, este por sua vez

\footnotetext{
${ }^{42}$ Como comentado por Oliveira (2005), um exemplo importante disto reflete-se no papel das organizações nacionais British Antarctic Survey e National para os estudos da camada de ozônio na década de 1980.
} 
entendido como inexoravelmente ligado ao avanço da divisão de trabalho capitalista. Essa falácia, de que os problemas sociais são resolvidos exclusivamente pelo incremento quantitativo da produção - entendido como não problemático e obtido por meio do progresso do conhecimento científico e tecnológico (ibid., p.179) -, é um dos traços centrais do que chamaremos de ideologia cientificista-positivista ${ }^{43}$.

A ideologia cientificista-positivista possibilitou uma relação de identificação entre ‘progresso científico’ com os modos capitalistas de produção (ibid., p.184) - em outras palavras, seriam também modos de produção a "tecnologia e a ciência incorporadas nas máquinas e instalações as quais dominam os trabalhadores como uma força produtiva distinta do trabalho" (Gorz apud Apple 1989, p.63). Sua proeminência teria vindo, por um lado, da sua eficácia em suprir "a racionalização requerida ao serviço dos interesses políticos e socioeconômicos dominantes” (Mészáros 2005, p.186) - ou 'racionalidade técnica', duramente criticada em especial pelas escolas de Frankfurt. Com efeito, o espírito científico tomado cientificista-positivisticamente não poderia ser mais adequado para tal, como exemplifica Mészáros (ibid., p.187):

Sua metodologia, fazendo uso quase ad nauseam de modelos, diagramas, fórmulas, "evidências" de estatísticas distorcidas, "observações em massa" e "entrevistas em massa" (baseadas em "amostras cientificamente representativas" - embora, na realidade, estritamente insignificantes), etc., refletiu uma necessidade vital e um imperativo prático na sociedade de commodities. Ou seja: garantir a reprodução do valor de troca numa escala constantemente crescente por meio da manipulação descomprometida dos processos sociais em todas as áreas da atividade, das "demandas" materiais geradas pelo "gerenciamento da oferta" para influenciar grosseiramente a opinião pública ao pretender representá-las objetivamente, e ao cinicamente "produzir" escassez artificiais em um mundo de abundância para "massajar" os fatos no intuito de provocar as respostas ideológicas e políticas necessárias em um público sistematicamente pobremente educado.

Por outro lado, seu grande 'sucesso' também se origina de sua eliminação radical da dimensão histórica e crítica, o que resulta em tese numa “'eternização’ $e$ [em uma]

\footnotetext{
${ }^{43}$ Mészáros (2005) utiliza termos diferentes em sua obra para se referir a este objeto, tais como 'positivismo’, 'cientificismo', 'positivismo cientificista' e ‘neopositivismo’. A forma como Mészáros os apresenta não sugere uma aproximação exata destes termos com o que filósofos da ciência em geral classificam como 'positivismo' ou 'neopositivismo' - que eventualmente podem ter contribuições para o EC, segundo Matthews (2004). No EC, os sentidos utilizados por Mészáros estão de certa maneira mais próximos daqueles utilizados por Kinchloe e Tobin (2009).
} 
legitimação ideológica do establishment” (ibid., p.185) - o mesmo tipo de movimento ideológico acusado por Chaui (2008, p.114) de se entender 'história’ como 'progresso' no sentido cientificista-positivista, de se explicar o passado pelo presente pela fabricação de histórias imaginárias. A não-historicidade propalada por esta visão de ciência será um elemento central para nosso argumento na próxima seção.

'Autoridade', 'neutralidade' e 'objetividade' são outros traços característicos da ideologia cientificista-positivista, oriundos de idealizações e distorções do conhecimento e prática científicas. Segundo Mészáros (ibid., p.182), além de servir de instrumentos de legitimação do capital, tais traços seriam usados para camuflar a natureza politicamente conservadora desta ideologia (ibid. p.185). Argumenta ainda que a origem destes mitos, em especial da neutralidade, está no que chama de alienação capitalista - e, ainda, que não são ‘erros’ ou conceptualizações equivocadas “passíveis de serem resolvidas através do trabalho de 'esclarecimento filosófico', como pretendem positivistas lógicas e filósofos analíticos”, mas sim “ilusões necessárias, com suas raízes firmadas no solo social produtivo e constantemente se reproduzindo nessa base” (ibid., p.198). Não raro, a ‘neutralidade’ e ‘objetividade’ são justificadas com base na ‘autoridade científica' (ibid., p.178), e vice-versa - como verificado em justificações ‘científicas’ em políticas de testes padronizados (Au 2013).

Continuando com Mészáros (2005, p.194), a ideia de que a ciência tem um desenvolvimento autônomo e independente da realidade social é uma simplificação de ciência, ideologicamente motivada. Isto é, em suma, a visão de que a ciência e tecnologia são ‘a-sociais’ e ‘a-históricas’ é uma mitificação que não se sustenta ao escrutínio crítico, pois, como coloca Mészáros, ambas estão profundamente enraizadas no contexto social e histórico de seu tempo (idem). Por outro lado, este enraizamento é esclarecedor quanto à existência da ideologia cientificista-positivista no capitalismo tardio. Como quase a totalidade de outros setores produtivos na contemporaneidade, a ciência foi raptada pelo capital - inevitavelmente sugado à lógica de alienação capitalista (ibid., p.197) -, e neste sentido, é tão ‘não-neutra’ e 'ideológica’ como qualquer outra faceta do setor produtivo contemporâneo (ibid., p.194). Isto sugere uma relação simbiótica entre o que Mészáros e outros autores acusam como cientificismo-positivismo e a ideologia neoliberal - por sua vez, isto favorece a hipótese de que pelo menos uma fração da incidência de concepções distorcidas sobre ciência, ostensivamente diagnosticadas nos últimos anos em pesquisas em EC, tenham natureza ideológica. 
As colocações acima levam a nossa consideração, compartilhada por Mészáros (ibid., 197), de que a ciência não é intrinsecamente ligada aos modos de produção capitalistas ou, ao capitalismo em si - ainda que o desenvolvimento da ciência moderna quase sempre estivesse ligado ao dinamismo do capital (idem) -, diferentemente da pervasiva ideologia cientificista-positivista. Esta, segundo o autor (ibid., p.188), é fundamentalmente tributária à hegemonia dominante e responsável pelos usos manipulativos da ciência. Contudo, Mészáros argumenta que tal disjunção entre ciência e capitalismo é concebível na prática somente "se a sociedade como um todo escapar com sucesso da órbita ao capital e prover uma nova base (...) no qual as práticas científicas floresçam a serviço de propósitos humanos”, e não do capital (ibid., p.195). Nesta direção, para o autor seria absurdo culparmos a ciência pelas implicações dos modos de produção capitalistas, da mesma forma como seria absurdo imaginarmos que a comunidade científica por si só poderia reverter estas implicações (o que seria, em absoluto, um raciocínio pautado justamente na ideologia cientificista-positivista) (idem). Analogamente, seria igualmente absurdo imaginarmos que a educação por si poderia reverter os retrocessos sociais causados pelo capitalismo, como enfatiza Mészáros (2006, p.45):

[A educação] não é a força ideologicamente primária que consolida o sistema do capital; tampouco ela é capaz de, por si só, fornecer uma alternativa emancipadora radical. Uma das funções principais da educação formal nas nossas sociedades é produzir tanta conformidade ou "consenso" quanto for capaz, a partir de dentro e por meio dos seus próprios limites institucionalizados e legalmente sancionados. Esperar da sociedade mercantilizada uma sanção ativa - ou mesmo mera tolerância - de um mandato que estimule as instituições de educação formal a abraçar plenamente a grande tarefa histórica do nosso tempo, ou seja, a tarefa de romper com a lógica do capital no interesse da sobrevivência humana, seria um milagre monumental.

Os apontamentos até então trabalhados permitem a seguinte síntese (não exaustiva), que dificilmente contém novidades essenciais: (i) a ciência e a tecnologia não estão ‘isoladas' da sociedade (como ideologicamente se propala), mas sim estruturalmente conectadas aos seus condicionantes históricos, sociais, políticos, culturais, entre outros; (ii) a ideologia neoliberal e a ideologia cientificista-positivista conduanam-se, e; (iii) concepções críticas de sociedade e de ciência coadunam-se. De fato, estes pontos foram enfatizados em numerosas e diferentes ocasiões em pesquisas em educação - em especial os últimos dois por teóricos críticos (Apple 2004, p.86). Contudo, a importância destes 
pontos não parece ter sido trabalhada o suficiente especificamente por pesquisadores na área de EC. Se tomarmos como hipótese que boa parte dos elementos que constituem o que hoje chamamos de concepções inadequadas de NdC tem natureza ideológica, tem-se que a ‘solução’ passa longe de uma questão tão somente ‘instrutiva' de NdC - ou, de sua inclusão (na forma de tenets) em testes padronizados, conforme apontamos na seção anterior.

O ponto (iii) acima exige uma componente política para o papel do conhecimento sobre ciência no EC - algo tão importante quanto a consistência histórico-filosófica de seu conteúdo e sua exequibilidade didática em diferentes contextos. Tal componente, por sua vez, nos levará ao argumento de que especificamente a HC no EC não deve apenas ter o papel de mostrar a ciência enquanto construção histórica, mas que precisa ser entendida (em especial a nível de formação de professores e também como estratégia de ensino) como uma contraideologia à ideologia cientificista-positivista e à ideologia neoliberal. Trata-se de um propósito audacioso para a HC no EC - em contraste com a defesa de Matthews (1998b) de que devemos ser modestos com os objetivos da HFC no EC-, todavia, minimamente necessário e urgente ao tempo em que vivemos.

Para finalizar esta seção, faz-se construtiva uma breve consideração - não exaustiva sobre a fragilidade epistemológica do que chamamos de concepção nuclear de ideologia, mencionada no início desta seção. Como aponta Magalhães (2016), tal fragilidade levada ao contexto da ciência leva ao intrincado problema da verdade em HFC - isto é, à sugestão de que existe uma forma a-histórica 'correta' de compreender a natureza. Com base na visão de George Canguilhem sobre o que chama ideologia científica ${ }^{44}$, Magalhães (2016, p.101) comenta que não se pode entendê-la dentro da acepção puramente marxista de ideologia, uma vez que a "ciência revela a realidade, ainda que construída sobre as bases materiais da sociedade”. Isto é, “uma ideologia científica não é uma falsa ciência, ou uma superstição, ela é uma hipótese que pode ser algum dia demonstrada verdadeira, como por exemplo, o atomismo" (idem). Tais considerações canguilhenianas (fundadas numa forma de realismo científico) permitem-nos afirmar que: (i) ideologia científica não seria uma ideologia no sentido marxista (tampouco é uma variante da ideologia cientificista-positivista); (ii) a ideologia científica seria inevitável à ciência (entendendo-a como processo histórico), e; (iii) esta ideologia manifesta-se enquanto hipóteses científicas que podem se mostrar verdadeiras (ou não) no futuro. É neste último sentido -

\footnotetext{
${ }^{44}$ Que o autor francês diferencia de 'ideologia dos cientistas', e que não necessariamente se refere à ideologia cientificista-positivista discutida anteriormente (Magalhães 2016).
} 
no qual uma ideologia se torna 'verdadeira' - que esta acepção seria incompatível àquelas marxistas comentadas nesta seção. Todavia, trate-se de um (outro) terreno bastante disputado em HFC. Afinal, a título de exercício de pensamento, poder-se-ia elencar a meta-indução pessimista sobre a HC (Laudan 1981) associada a uma concepção rupturista, e argumentar que determinada visão de mundo científica (ou, neste caso, determinada ideologia científica) que se mostrou anteriormente 'verdadeira' pode, eventualmente, se mostrar falsa no futuro. Neste sentido, 'ideologia científica' seria uma forma de 'falsa ciência', mais próxima, portanto, aos sentidos marxistas. Em contrapartida, embora muitas abordagens historiográficas da ciência sustentem evidências de fortes 'descontinuidades ontológicas’ em mudanças científicas ${ }^{45}$, há também numerosas evidências de continuidade estrutural na HC (Chakravartty 2017, p.23; Worral 1989), o que mostra que podemos ponderar as conclusões do exercício de pensamento acima. Em suma, diferentemente do que estamos chamando aqui de ideologia científica em tese, intrínseca ao fazer científico, conforme rapidamente esboçado acima -, entendemos que a ideologia cientificista-positivista - por sua vez extrínseca e parasita à ciência, usando-a a favor da dinâmica do capital e da manutenção das desigualdades sociais - deve ser combatida. Enquanto na ideologia científica, o 'falseamento da realidade’ se dá (idealmente) de forma involuntária durante o empreendimento científico, buscando aprender sobre o mundo exterior independente, na ideologia cientificistapositivista o efeito de tal falseamento é interessante (poder-se-ia dizer, desejado por setores dominantes) por prender o mundo social, através de mecanismos que se sustentam e são sustentados pela ideologia neoliberal. Por uma contraideologia as estas últimas, apresentamos na próxima seção o primeiro argumento central deste trabalho.

\section{Primeiro argumento: conhecimento sobre a ciência como contraideologia pelo conflito - ou, um papel político para a história da ciência no ensino de ciências}

Naturalmente, a presença - e as consequências - daquilo que chamamos na seção anterior de ideologia cientificista-positivista sobre a educação não é objeto de estudo

\footnotetext{
${ }^{45} \mathrm{Ou}$, em diferentes nomenclaturas de filósofos e historiadores da ciência, mudança de: paradigma (Kuhn); programa de pesquisa (Lakatos); teoria global (Feyerabend); problema conceitual / modelo reticulado (Laudan), entre outros (Laudan et al1993, p.10).
} 
somente de teóricos (críticos e pós-críticos) de currículo, mas também de pesquisadores em EC. A título de exemplo, Kinchloe e Tobin (2009, p.513) discursam sobre a presença despercebida do que chamam de cripto-positivismo na cultura ocidental, o qual é por vezes - segundo os autores - declarado 'morto’ na educação. Argumentam, em sintonia a autores como $\mathrm{Au}$ (2011; 2013), de que isto estaria por trás da lógica de testes padronizados e da exclusão de ‘conhecimentos que desafiam o status quo’ (Kinchloe \& Tobin 2009, p.514). Apontam que mesmo autores críticos ao positivismo, tais como Kuhn e Feyerabend, usaram princípios positivistas em suas críticas (ibid., p.516). Ainda, afirmam que muitas características positivistas permeiam a pesquisa acadêmica - tais como a metódica científica, descontextualização, universalidade, reducionismo e unilateralismo (ibid., p.519) -, que o Positivismo reflete a crença na 'superioridade do Oeste’ (ibid., p.520) e que opera como uma força hegemônica em prol do status quo (ibid., p.523). Sua força proviria, dentre outros pontos, da capacidade de "negar sua própria existência enquanto transforma em vilão tudo aquilo que lhe aponta" (ibid., p.526). Embora os autores não mencionem explicitamente, trata-se de uma compreensão do que chamam (cripto) Positivismo enquanto uma ideologia, a despeito das particularidades de suas posturas, com consequências substanciais no EC.

Numa via semelhante, Désautels (2015, p.344) argumenta que todo ensinamento de ciências é inevitavelmente ideológico. Ao contrário do que por vezes se afirma popularmente, Désautels afirma que a ideologia cientificista (ibid., p. 345) se faz também presente no EC, em especial na crença dos estudantes de que "os conhecimentos científicos vem de parte alguma e são desprovidos de contingências históricas e sociais que possibilitaram sua produção" (idem). Na tentativa de ilustrá-la em discursos textuais presentes no EC, o autor desenvolve progressivamente quatro excertos fictícios (porém, verossimilhantes aos encontrados em materiais educacionais) sobre a descoberta do DNA:

[I] Dois jovens pesquisadores, Francis Crick e James Watson, descobriram em 1953 a estrutura da molécula de DNA, e assim revelou-se o segredo da hereditariedade (ibid., p.356).

(...) [II] Dois jovens pesquisadores, Francis Crick e James Watson, depois de algumas tentativas mal sucedidas, finalmente propuseram em 1953 um modelo molecular helicoidal para explicar os dados coletados na difração de raios-X de amostras de DNA. O trabalho deu impulso a pesquisas genéticas destinadas a fornecer explicações sobre os fenômenos associados ao conceito de hereditariedade (ibid., p.357) 
(...) [III] Dois jovens pesquisadores, Francis Crick e James Watson, trabalhavam na Universidade de Cambridge, na Inglaterra, no Laboratório Cavendish, liderado por Sir William Laurence Bragg, Prêmio Nobel por seu trabalho, analisando estruturas cristalinas com raios X. Apesar da relutância expressada por seu diretor quanto à continuação de seu projeto, eles finalmente propuseram em 195,3 após algumas tentativas mal sucedidas, um modelo molecular helicoidal para entender os dados produzidos por radiografia de amostras de DNA via Difração de raios X, no laboratório administrado por J. T. Randall no King's College de Londres. O trabalho publicado na revista Nature deu um impulso à pesquisa em genética com o objetivo de fornecer uma explicação dos fenômenos associados ao conceito de hereditariedade. (idem)

(...) [IV] No final da Segunda Guerra Mundial, vários químicos e físicos, moralmente chocados com o horrível desastre humano causado pelo lançamento da bomba atômica em Hiroshima e Nagasaki, abandonaram completamente suas áreas de pesquisa e se voltaram para a biologia. Eles também foram influenciados, aparentemente, pela tese materialista e reducionista do físico alemão Erwin Schrödinger, refugiado na Irlanda. Esta tese, formulada em seu livro 'O que é a vida?' (1945) sugere considerar o que agora chamamos de DNA como um cristal periódico com um código que controla o desenvolvimento dos organismos vivos. Quando os dois pesquisadores, Francis Crick e James Watson, começaram seu trabalho na Universidade de Cambridge, na Inglaterra, no laboratório de Cavendish administrado por Sir William Laurence Bragg, vários pesquisadores, incluindo o americano Linus Pauling, duas vezes no Prêmio Nobel química, acreditava que a produção de um modelo da molécula de DNA seria um passo importante na compreensão dos fenômenos relacionados à hereditariedade. É neste contexto que Crick e Watson, depois de algumas tentativas mal sucedidas - e, conhecendo o erro cometido por Pauling no modelo de DNA proposto em um artigo publicado na revista Nature -, finalmente propõem um modelo molecular helicoidal para explicar os dados produzidos por Rosalind Franklin, que trabalhava no mesmo laboratório e era especialista em radiografia de amostras de DNA de raios $\mathrm{X}$.

A despeito do crescimento exponencial em extensão e complexidade, os últimos excertos - em especial o último - procuram deixar claro, por meio da HC, as nuances políticas, militares, econômicas, éticas, intelectuais e materiais envoltas ao episódio considerado (idem). A alta carga ideológica no primeiro excerto se traduz então no ‘ocultamento’ destas, sugerindo Watson e Crick ‘desvelaram’ o DNA independentemente de qualquer coisa (a não ser eles mesmos), suprimindo conflitos e controvérsias 
envolvidas (como o caso de sexismo sobre Franklin) e tendendo a um realismo ingênuo insustentável. Para Désautels, os excertos projetam 'ideologias' diferentes, e sua discussão deve favorecer reflexões críticas sobre eles (ibid., p.349), e ressalta a importância das palavras no EC - como nos excertos acima - contra o que chama "alfabetização científica inspirada pela ideologia neoliberal, orientada ao desenvolvimento sociocientífico no contexto de competição econômica mundial de todos contra todos" (idem $\left.{ }^{46}\right)$.

Apple (2004 p.79) foi um dos importantes pioneiros em apontar que o tratamento do conflito em disciplinas escolares correlaciona-se com a aquiescência política dos estudantes quanto a perspectivas sociais e intelectuais que por sua vez coadunam com a manutenção da distribuição de poder e desigualdades na sociedade. Em Ideologia e Currículo, Apple afirma que este problema manifesta-se tanto nas disciplinas de ciências humanas - em especial, nas concepções de sociedade - como também nas chamadas de ciências exatas - por sua vez, nas concepções de ciência. A ausência do conflito nestas é, segundo o autor, um resultado do trabalho da hegemonia ideológica em naturalizar que “instituições, regras do senso comum, e conhecimento sejam relativamente vistas como dadas a priori, neutras, e também basicamente imutáveis por existirem por 'consenso"' (ibid., p.78), e ainda, que uma sociedade "baseada no capital cultural técnico $e$ acumulação individual de capital financeiro como único mundo possível” (idem). Ao longo desta obra, o autor exemplifica em mais de um momento o que seria uma concepção de sociedade sem conflitos:

\footnotetext{
A perspectiva encontrada em escolas inclina-se pesadamente sobre como todos os elementos de uma sociedade, desde o carteiro e o bombeiro no ensino fundamental às instituições em cursos cívicos no ensino médio, são conectados entre si em um relacionamento funcional, cada um contribuindo para a contínua manutenção da sociedade. Dissensos internos e conflitos em uma sociedade são vistos como inerentemente antiéticos ao funcionamento suave da ordem da social. Consenso é mais uma vez uma característica salientada (ibid., p.87).
}

Ainda que estas considerações de Apple, publicadas há mais de trinta anos, façam mais sentido ao seu contexto histórico e geográfico, elas continuam (infelizmente, num certo

\footnotetext{
${ }^{46}$ Uma análise semelhante, por exemplo, pode ser feita sobre as histórias das origens da teoria da relatividade restrita (Noronha 2011; 2014; Noronha \& Gurgel 2012a; 2012b). De forma geral, muitos livros textos de ensino básico e superior mantêm uma ‘história ideológica' da relatividade restrita, conectando-a diretamente a resultados experimentais da época e ignorando os contextos sociais, culturais, tecnológicos e políticos da época.
} 
sentido) atuais e urgentes. Ainda em Ideologia e Currículo, a problematização de Apple sobre perspectivas de ciência 'limpas' de conflito na educação científica - especialmente na educação básica - parte do fato destas não promoverem uma concepção de ciência enquanto construção histórica e humana. Ainda, contribuem para a aprendizagem pelos estudantes de uma visão irrealista sobre o papel dos conflitos à ciência (ibid., p.82) - no qual estes se resumem principalmente ao 'conflitos' entre observações (tidas como neutras) e teorias (vistas como elucubrações que 'pairam' o mundo), resolvidos 'objetivamente' - 'objetividade' esta que Apple chama de 'vulgar', por refletir um grande receio por conflitos intelectuais, morais e políticos (2004, p.83). Como exemplifica em sua obra, o empreendimento científico nisto que chama de ‘ideal positivista’ tende a ser:

(...) visto (e ensinado) como sempre sujeito à verificação empírica sem influências externas, pessoais ou políticas. "Escolas de pensamento" na ciência não são mencionadas em geral, e quando o são, critérios "objetivos" são usados para persuadir os cientistas de que um lado está correto e o outro errado. (...) os estudantes são apresentados a uma teoria consensual da ciência, que desmerece os sérios desentendimentos sobre metodologia, objetivos e outros elementos que compõem os paradigmas de atividade dos cientistas. Pelo fato de o consenso científico ser continuamente exibido, os estudantes não tem possibilidade de compreender que sem discordância e controvérsia a ciência não avançaria- ou, avançaria a um ritmo muito mais lento (idem, grifos nossos).

Apple, apropriando-se da obra de Kuhn, defende assim que uma das características centrais da ciência é seu desenvolvimento histórico em termos de conflitos de teorias rivais, entre propostas revolucionárias e paradigmas estabelecidos (idem). Sustenta que a ciência não é necessariamente acumulativa, que não procede de acordo com critérios consentidos, mas sim movida por "revoluções que fazem com que grupos de cientistas reorganizem e reconceituem os modelos pelos quais eles tentam entender e manipular o mundo" (ibid., p.84). Apple argumenta pelo viés do ideal positivista - o que chamamos de ideologia cientificista-positivista - a tendência dos estudantes não serem apresentados aos conflitos entre teorias científicas (atuais ou do passado). Tampouco lhes é esclarecido que nem sempre os critérios científicos na escolha de teorias são, segundo Apple, suficientes (idem). Em suma, o ‘currículo oculto’ no EC seria, para o autor, o ocultamento dos conflitos e controvérsias científicas - elementos que justamente caracterizam a própria ciência. 
A noção de conflito em ciência, na interpretação de Apple, é por vezes inseparável das noções de competição e prestígio acadêmico, como o autor exemplifica com mesmo episódio discutido por Désaultels (2015) - a descoberta do DNA e a corrida entre Watson e Linus Pauling. Sem desmerecer completamente os papeis que os ideais críticos de objetividade, neutralidade (ver Reiss \& Sprenger 2017) e testes de hipóteses têm na rotina científica, Apple (2004, p.85) argumenta que não se deve 'demonizar' a priori o empreendimento científico e suas ramificações, mas sim prover-lhe uma visão mais verossimilhante no educação - mostrando, por exemplo, que parte da sua sustentação se dá com base no comprometimento psicológico dos cientistas com teorias, modelos e visões de mundo científicas. Em especial, Apple é mais normativo quanto ao conceito de verdade científica, propondo a adoção do conceito de ‘verdade-até-o-momento’ (truthuntil-further-notice), que evidenciaria o caráter histórico da ciência e seu processo contínuo de mudanças (ibid., 94). Uma vez que o conceito de conflito aspira em suas origens o impulso marxista de transformação social, negá-lo nos currículos significaria, como argumentaram Giroux e Paraskeva (2011, p.10), a supressão da história - no caso do EC, a supressão da HC. O papel da HC para combater o ideal positivista (-cientificista) enquanto ideologia do não-conflito no EC é claro na obra de Apple (ibid., p.93):

\begin{abstract}
A história da ciência pode ser vista com uma dialética manente de controvérsias e conflitos entre defensores de programas de pesquisa e paradigmas concorrentes, entre respostas aceitas e desafios a estas "verdades". Desta maneira, a ciência em si pode ser apresentada com uma maior fundamentação histórica pela documentação de revoluções conceituais necessárias para que grandes avanços ocorram.
\end{abstract}

O que Apple e outros autores sugerem é uma concepção de ciência com base no conceito de conflito, e também em seus próprios conflitos (como as controvérsias científicas). As principais fontes do progresso científico baseiam-se no conflito, na ‘disputa entre paradigmas', segundo Paraskeva (2011,p.10), sempre envolvidas dos contextos sociais, tecnológicos e políticos. Apple (2004, p.94), neste mesmo sentido, argumenta que o estudo "de como procederam as revoluções conceituais em ciência poderia contribuir para uma perspectiva menos positiva à ideia de consenso como único modo de progresso" ${ }^{47}$. Em suma, estes autores defendem algo não muito diferente do que

\footnotetext{
${ }^{47}$ Cabe mencionar que enquanto um não historiador ou filósofo da ciência, o discurso de Apple sobre HFC não é necessariamente consistente e coerente do ponto e vista dos estudos mais centrais ou recentes sobre a ciência. Isto fica evidente em seu uso nem sempre esclarecedor de conceitos e termos intensamente
} 
muitos autores da área de HFC e NdC no EC vêm defendendo nos últimos anos. Porém, uma diferença é que esta defesa agora está fundada em teorias críticas de currículo, primariamente preocupadas com os problemas estruturais que envolvem a educação e a sociedade como um todo, intrincadas com as realidades sociais e efeitos de políticas públicas, assim como com as ideologias que permeiam os diversos segmentos sociais e culturais. Este é um primeiro aspecto do argumento deste capítulo.

Ao propósito deste capítulo, uma de nossas premissas é a de que a visão de 'teoria consensual da ciência' criticada por Apple serve de certa forma como um espelho à proposta da VCNdC. Ainda que o conteúdo dos ‘sete pontos de Lederman’ comumente apresentado na literatura possa sugerir que eles potencialmente contemplem alguns aspectos que em tese possam mostrar conflitos no desenvolvimento histórico e na natureza do conhecimento científico - tais como a crítica ao mito do único método científico, a defesa da natureza provisional da ciência e seu enraizamento cultural e histórico-, enquanto mais um instrumento em políticas educacionais mercantilizantes, a VCNdC tende a perder todo o potencial no ato de ensino-aprendizagem. Isto por razão de sua inclusão em testes padronizados, e a consequente distorção e ‘padronização' da HFC e NdC aos moldes daqueles, como exemplificado na questão do vestibular FUVEST em seção anterior. Por outro lado, a natureza categórica dos tenets pode levar a simplificações e distorções da HFC, como já apontado por vários críticos (Irzik \& Nola 2011; Matthews 2012), assim como problemas acerca da aplicabilidade da lista a diferentes disciplinas - algo insuficientemente rebatido por Lederman e Lederman (2014). Pode-se interpretar que as asserções da lista de Lederman (2007) transparecem

debatidos na literatura especializada como ‘acumulação', ‘avanço' ou 'progresso' e principalmente 'verdade científica'. Por outro lado, sua apropriação da obra de Kuhn é criticável, o que infelizmente foi algo comum também com outros autores dentro e fora da área de HFC - como exemplifica Condé (2017, p.92), Kuhn passou anos respondendo a críticas fundadas em interpretações descuidadas das suas obras seminais, entre elas a ideia de que ele seria relativista. É relevante comentar que a publicação da importante obra de Kuhn A Estrutura das Revoluções Científicas em 1962 se mostrou oportuna à época, particularmente devido aos movimentos de maio de 68 que intensifaram seu impacto na academia, como lembra Bourdieu (2000, p.32). Ao mesmo tempo, porém, propiciou banalizações da obra e conceitos utilizados na obra de Kuhn (Young 2016, p.32). A título de exemplo, o termo 'mudança de paradigma', como coloca Grant (2011b, p.95), virou uma 'celebridade' por si só fora da HC. Ainda que não necessariamente recaia nestas vulgarizações, Apple em Ideology and Curriculum mostrou-se relativamente preso a um tipo de 'rupturismo ideológico', problematizando-o insuficientemente. Bourdieu (2000, p.32) sugere que mesmo Kuhn teria se surpreendido com a ressonância histórica de sua obra com o 'espírito contestador' advindo dos movimentos mencionados. Comenta com certa ironia que Kuhn, “que nada tinha de revolucionário, foi adaptado, um pouco contra vontade, como mentor pelos estudantes da universidade de Columbia e integrado no movimento da 'contracultura' que rejeitava a 'racionalidade científica' $e$ exaltava a imaginação contra a razão” (idem). De fato, como salientam Reiss e Sprenger (2015, p.11), tanto as ideias de Kuhn como de Feyerabend - dois ícones do socioconstrutivismo - sobre subdeterminação teórica e objetividade científica foram particularmente mal interpretadas. 
uma 'trivialidade’ ou um suposto ‘consenso' de historiadores e filósofos da ciência que na verdade escondem a natureza conflitiva em cada uma delas. Consentindo sobre a natureza empírica da ciência, Lederman (apud Matthews 2012) afirmam categoricamente que “cientistas não têm acesso direto à maioria dos fenômenos naturais” - embora esta afirmação pareça superficialmente sensata, ela oculta o inquietante debate entre realistas e antirrealistas científicos (e também entre cientistas) sobre a realidade dos inobserváveis (Chakravartty 2017). A distinção rígida entre teorias e leis (ver Lederman 2007) falha em reconhecer que ambas as conceitualizações tem natureza histórica, tendo suas fronteiras nem sempre claras, e ainda que uma (importante) terceira categoria - a de modelos (teóricos ou experimentais) - não pode ser encaixada em nenhuma delas ${ }^{48}$. Com efeito, a tal distinção rígida não é uma prioridade para os próprios cientistas (Hodson 2014, p.921). Ainda, a argumentação de Lederman (2007) de que o conhecimento científico tem natureza provisional, 'nunca absoluto ou definitivo', 'sujeito a mudanças', flerta demasiadamente com a historiografia rupturista, e penumbra possibilidades de continuidade estrutural em mudanças científicas (Worral 1989), ou de uma dialética entre continuidade e descontinuidade. Hodson (2014, p.922) alerta que interpretações muito literais de tal ponto de Lederman podem ser contraprodutivas e levar estudantes a não distinguir as colocações 'a verdade científica absoluta é inalcançável-inexistente’ de ‘a ciência é incerta em tudo' - é preciso reconhecer, como o autor, de que "nós sabemos muitas coisas sobre o universo, ainda que reconheçamos que muitos de nossos sistemas teóricos ainda estão sujeitas a revisões ou rejeições”.

Assim, argumentamos, a retórica dos tenets da VCNdC tende a transmitir uma imagem 'cinza', falsamente ascética e sem conflito sobre a ciência (Robilotta 1989) - ao passo que uma imagem mais realista da ciência tem 'pretos' e 'brancos' - ou melhor, 'brancospretos’ -, permeados de tensões e conflitos que engrenam seu desenvolvimento histórico e conceitual, dando-lhe vida e humanidade. Como afirma Robilotta sobre aprender física -

\footnotetext{
${ }^{48}$ Estas e outras ponderações podem ser encontradas em Hodson (2014). Ao se defender que a imaginação faz parte da atividade científica, e que entidades como átomos são 'antes modelos teóricos funcionais do que cópias da realidade', é preciso salientar que em muitos domínios a atividade científica é condicionada pelas realidades econômicas e sociais. A afirmação de que o conhecimento científico tem natureza teórico-dependente tira de foco a importante questão de quanto e de que forma ela é teóricodependente - é possível resgatar episódios históricos no qual essa dependência aparentemente foi mínima, e em outros onde ela foi crucial. $\mathrm{O}$ fato de que a ciência tem enraizamento social e cultural é lugar comum entre historiadores, filósofos e sociólogos da ciência - porém, a trivialidade de tal constatação não dá sequer indícios da complexa questão da concomitância entre a 'transcendência' social do conhecimento científico maduro de suas origens históricas e culturais (ver Young 2016a; Bourdieu 2001) e seu enraizamento nas condições materiais e econômicas de cada época. A crítica ao mito do método científico 'único e infalível' é importante, mas sua ênfase não pode levar à ideia de que a ciência não tem método algum, ou, que os que existem são completamente arbitrários.
} 
o que certamente é também valido sobre aprender sobre a física, ou sobre a ciência -, o conflito, "transforma o cinza em branco e preto, que daí em diante dançam ao som da sua própria dialética”, e proporciona, nas palavras do autor, “prazer” (ibid., p.18). Esta metáfora é central à nossa compreensão da noção de conflito, por exprimir uma visão dinâmica sobre o desenvolvimento histórico do conhecimento científico. Ela é mencionada por Levins e Lewontin (2009, p.276), que comentam sobre escolas de pensamento que veem o mundo com tons de cinza, nas quais se afirma que " $a$ verdade está entre [os extremos branco e preto]” e que se 'resolve' as contradições pelo consenso. Os autores fornecem um exemplo simples em sua área sobre o que chamam de princípio da dialética no conhecimento biológico:

(...) no sistema predador-presa de roedores e corujas, as duas espécies são polos opostos do processo, predação determinando simultaneamente a taxa de mortalidade de roedores e a taxa de nascimento de corujas. Não é que os roedores sejam o oposto de corujas em algum sentido ontológico, ou que os roedores impliquem corujas ou não possam existir sem corujas. Mas dentro do contexto desse ecossistema em particular, sua interação ajuda a impulsionar a dinâmica populacional, o que mostra uma espetacular flutuação de números.

Os pares dialéticos 'brancos-pretos’ da ciência, em analogia aos sistemas biológicos predador-presa, podem ser identificados dentro do universo conceitual (conforme hoje este é concebido) da HFC e NdC nas tensões entre 'continuidade' e 'descontinuidade' (Sheehan 1993, p.4), 'objetividade’ e ‘subjetividade’ (ver Daston \& Galison 2007), 'progresso' e 'digresso, ${ }^{49}$, entre outros. Pode-se argumentar então que tomar estes pares dialéticos - continuidade-descontinuidade, objetividade-intersubjetividade, progressodigresso - como elementos intrínsecos à HFC é um passo essencial a uma compreensão

\footnotetext{
49 'Digresso' significa literalmente desvio de rumo. Enquanto na ideologia positivista a noção de progresso se fundamenta num triunfalismo ingênuo - isto é, vendo a HC como uma sequência sucessiva (no sentido de sucesso) e cumulativa de descobertas (Burke 2016, p. 162) -, uma visão 'digressiva' ingênua da HC seria o exato oposto - uma sequência de desventuras, aleatórias e nada cumulativas -, próximo a visões relativistas epistêmicas. Entendemos, amparados parcialmente em Burke (idem), que uma concepção razoavelmente crítica de HC deve partir, entre outros pontos, da constatação de que a ciência nem 'segue um rumo' nem 'desvia de rumos'. Um rápido (porém específico, e de forma alguma exaustivo à questão) exemplo da história da física, mais especificamente da teoria da relatividade, pode ajudar a exemplificar esta questão. É relativamente conhecida a reação de Einstein a proposta do formalismo quadrivetorial de Minkowski pouquíssimos anos depois da publicação de seu artigo de 1905, 'inaugurador' da teoria da relatividade restrita - chamou-a de "pura luxúria" (Einstein Papers 1993, p.506), afirmando inclusive que na mão de matemáticos mal reconhecia sua própria teoria. Num olhar retrospectivo, é difícil não entender a contribuição de Minkowski, apesar da reação de Einstein no calor do momento, como um ‘progresso’ contudo, ela foi um ‘digresso' naquele contexto específico, se identificarmos as abordagens usuais da época no que tange a física teórica.
} 
crítica sobre a ciência. Em tais elementos não se almeja uma 'resolução por consenso', mas antes a recuperação do conflito no 'consentido' - isto é, recuperar do cinza o pretobranco $^{50}$.

Longe do conceito de conflito, o apelo por uma compreensão histórica e crítica da ciência pretendida pela VCNdC e seus defensores dá lugar a uma HC enquadrável ao formato de testes padronizados - a qual, ao invés de mostrar a natureza conflitiva do desenvolvimento histórico da ciência, não passa por funcionar como uma visão ideológica, ‘cinzenta', sobre a ciência, ‘decorada’ para os vestibulares e avaliações de nível. Neste sentido, a defesa por uma visão crítica sobre a ciência no EC deve ir além dos (necessários) escrutínios acadêmicos a muitas mãos e cheia de disputas sobre NdC e HFC. Pelos elementos levantados nas seções anteriores - em especial, a urgência em resistir à galopante mercantilização da educação e a hegemonização dos testes norteados pela ideologia neoliberal (e justificados pela ideologia cientificista-positivista) -, tal defesa deve levar minimamente em conta, entre outros pontos, por quais políticas educacionais concretizarão tais ideais na realidade educacional e quais interesses políticos para tais ideais no EC - ainda que estas considerações aumentem drasticamente a complexidade do problema em questão ${ }^{51}$. Desta forma, antes de nos perguntarmos 'qual compreensão sobre a ciência é mais didaticamente viável', ou 'qual compreensão sobre a ciência é mais bem filosoficamente fundada’ (ambas perguntas relevantes, sem dúvidas), devemos nos perguntar: qual(is) compreensão(ões) sobre a ciência é(são) mais apta(s) a fornecer subsídios para combater a ideologia do não-conflito no EC?

Tal pergunta certamente oferece um grande leque de respostas, dando pouco espaço a respostas categóricas e totalizantes. Ela também vai além de uma discussão meramente epistemológica, abarcando questões sociais, políticas, éticas entre outras - as quais, pelos horizontes que estendem, não poderão ser aqui discutidas em sua plenitude. Por estas razões, nosso argumento neste capítulo está longe de ser uma panaceia - seus apelos teórico-conceituais, sem o aporte dialético em ações como pressões sociais e políticas

\footnotetext{
${ }^{50}$ Como reporta Galison (2008), muitos das questões que ainda orbitam a 'unidade' da HFS (à qual se poderia incluir, também, a sociologia e psicologia da ciência, entre outras áreas) contém em si elementos conflitos - internalismo e externalismo, micro-história e macro-história, natural e artificial, pureza e impureza. Embora o autor entenda estas questões como 'problemas', não foge à sua leitura o entendimento de que essas tensões envolvem justamente o desenvolvimento e amadurecimento da área de HFC.

51 Importa lembrar que as preocupações referentes às dificuldades didáticas e pedagógicas da aproximação da HFC ao EC, e também à elaboração de concepções menos ingênuas de NdC entre professores e estudantes, aparentemente tiveram mais ênfase na literatura especializada nos últimos decênios. Inversamente proporcional a isto (porém, não menos importante), os interesses ou propósitos políticos tendem a ser raramente explicitados.
} 
contra os problemas destacados nas seções anteriores, perdem seus possíveis sentidos. Ainda, ele está longe de desvelar possíveis métodos práticos de como combater efetivamente a ideologia do não-conflito, servindo antes como uma ponte possibilitando um maior diálogo entre duas áreas de pesquisa - HFC e NdC no EC e teorias de currículo.

Uma forma de combater a ideologia do não-conflito pode ser possível por meio de uma contraideologia do conflito. Contraideologias - as quais compartilham o ar com as utopias (Bosi 2010, p.394) - enfrentam (ou ao menos resistem) o presentismo e a falsaverossimilhança das ideologias, desestabilizam o presente desobstruindo possibilidades de compreensão do real (ibid., p.136). No contexto deste capítulo, uma contraideologia significa o enfrentamento de processos e políticas de mercantilização da educação, da adoção de políticas de testes padronizados e o ‘acinzamento’ da HFC e NdC decorrente destas políticas. Naturalmente, dado o panorama atual das circunstâncias especialmente no cenário brasileiro, aparentemente a resolução destes problemas dar-se-ia apenas numa situação utópica - daí a proximidade com o conceito de contraideologia. Muito embora a acepção pejorativa dada ao termo por discursos conservadores (idem), e também ao jargão pós-moderno de descrença com utopias, entenderemos a utopia-contraideológica como elemento indispensável para uma visão crítica em educação - em especial em EC.

Uma abordagem contraideológica da NdC envolve perceber relações entre diversos campos de força hoje atuantes - por exemplo, a mercantilização da educação e a mercantilização da ciência. Uma ligação entre ambos e o enfraquecimento do papel da HFC e NdC no EC é brevemente esclarecida por Oliveira (2013, p.2478):

A democratização da ciência (...) pressupõe a alfabetização científica, ou seja, uma postura cidadã suficientemente informada para poder pensar criticamente sobre a ciência e seu papel na sociedade. Isso reforça o que pode ser considerado o lema da [revista] Science \& Education, a proposição de que o ensino da ciência deve ser não só da ciência, mas também da ciência, bem como da sua implicação, a necessidade de introduzir a história, a filosofia e a sociologia da ciência nos currículos científicos. (...) tendências direcionadas à mercantilização da ciência não irão favorecer conhecimentos que possam questionar a solidez de seus objetivos. (...) [A] mercantilização da educação (...) envolve um afastamento da formação ampla (...) e uma aproximação ao treinamento profissional ao longo de linhas determinadas por necessidades do mercado. Nas políticas curriculares resultantes dessas tendências, não há lugar para o pensamento crítico sobre o papel da ciência e da tecnologia na sociedade. 
Uma defesa mais profunda da HFC e NdC no EC não pode ser feita sem a consciência de que há hegemonias ideológicas que privilegiam o treinamento (para o mercado) aos conhecimentos científicos (Leher \& Vittoria 2016, p.113), de que é preciso resistir à lógica de testes padronizados que começam a fazer uso da abordagem de tenets da VCNdC - e que justificam a 'política da culpa' a professores e estudantes (Bauer, Alavarse \& Portela 2015, p.1372) -, de que outra ciência (não mercantilizada, não guiada pelo neoliberalismo) é possível em um ambiente pós-neoliberal (Oliveira 2013, p.2482; ver Mészáros 2005), de que uma compreensão de sociedade sem naturalizações ideológicas (das desigualdades sociais, do sistema econômico capitalista, da estrutura familiar tradicional patriarcal, entre outros) é possível. Ainda, tal defesa também não pode ser feita sem se combater a ideologia cientificista-positivista, a qual obscurece a natureza conflitiva do desenvolvimento da ciência e seu caráter histórico. Como bem coloca Apple (2004, p.78), procurando justificar a inclusão do conflito nos currículos:

(...) [A hegemonia ideológica] requer que instituições, regras do senso comum e o conhecimento sejam vistas como 'pré-dadas', neutras e basicamente imutáveis, pois todas elas existem por “consenso” Assim, o currículo é levado a enfatizar os pressupostos hegemônicos, os quais ignoram o funcionamento real do poder na vida cultural e social, e que apontam à naturalidade de aceitação, (...) e a uma visão positivista em que o conhecimento é divorciado dos atores humanos que o criaram.

O principal engate entre a VCNdC e os celeumas apontados sobre a mercantilização da educação, testes padronizados e ideologia do não-conflito é a sua forma de tenets consagrada na literatura, ainda que posta em suspeita pelos próprios autores (Lederman \& Lederman 2014a), num movimento de reação à onda de críticas nos últimos anos. A rigor, abordagens de NdC sistematizadas em tabelas, matrizes ou imagens estariam também sujeitas ao enquadramento de testes padronizados - ainda que não de forma tão direta como os pontos da visão consensual. Poderíamos assim afirmar que a teoria crítica de currículo nos sugere que a presença da NdC nos currículos não deve se dar na forma de abordagens com sistemáticas passíveis de serem 'enquadradas’ nos moldes dos testes padronizados de ranqueamento. Além do já mencionado problema relacionado ao fenômeno 'teaching-to-test' apontado por Au (2009) no contexto estadunidense, sistemáticas facilmente enquadráveis - tais como listas ou matrizes - fatalmente dariam espaço a outro fenômeno conhecido, a memorização dos tenets sobre a $\mathrm{NdC}$ pelos 
estudantes - um problema, por exemplo, análogo àquele no ensino de História referente à memorização de datas e vultos nacionais (Toledo 2004).

Distante da possibilidade de prazer, nos termos de Robilotta (1989), ambos os fenômenos mencionados acima tendem levar à aversão (tanto de estudantes como de professores) à temática da HFC e NdC, enquanto mais um 'conteúdo burocrático', analogamente mais uma vez ao ensino cronológico de História - como atesta a observação quase centenária de Mendes (apud Nadai 1993):

\begin{abstract}
Nossos adolescentes também detestam a História. Votam-lhe ódio entranhado e dela se vingam sempre que podem, ou decorando o mínimo de conhecimentos que o 'ponto' exige ou se valendo lestamente da 'cola' para passar nos exames. Demos ampla absolvição à juventude. A História como lhes é ensinada é, realmente, odiosa (...)
\end{abstract}

Certamente não é um exagero dramático afirmar que não queremos que os estudantes odeiem HC (ou a HFC e a NdC de forma geral). Uma medida que poderia impedir isto (ainda que a reação de estudantes seja um fenômeno complexo e obviamente não decorrente apenas da realidade escolar) é, sem meios termos, afastar abordagens de NdC com sistemáticas facilmente enquadráveis em testes padronizados (balizados à lógica neoliberal) no EC. Isto é, é preciso um condicionante de forma de apresentação e definição da NdC. Todavia, dispensar a abordagem por tenets nos currículos - algo que em si já seria um forte abalo na área de pesquisa devido à sua popularidade e à propensão ao seu uso em questionários de concepções de NdC e outros -, traria, aparentemente, um dilema. Por muitos anos lamentou-se que diversas orientações e apelos da área de pesquisa em EC não eram concretizados em parte por força da seleção dos conteúdos nos grandes vestibulares - como foi (ainda é, em muitos casos) o caso do ensino de física moderna e contemporânea no nível básico (Guerra, Braga \& Reis 2007, p.575; Oliveira, Vianna \& Gerbassi 2007, p.451). O tom das declarações de Lederman, McComas e outros sobre a importância da presença (na forma de tenets) da NdC (numa acepção próxima à visão consensual) em documentos curriculares como o NGSS sugere que para estes autores seria lamentável dispensá-la - para Lederman (apud McComas \& Nouri 2016, p.20), já foi suficientemente lamentável o fato dela não ter proeminência no documento -, uma vez que a tão almejada visão crítica sobre a ciência defendida na área teria cada vez menos relevância no EC por força de sua ausência nos currículos (e, consequentemente, nos testes padronizados). 
Tal dilema, no entanto, é falso. Entendemos que não há motivos para acreditar que dispensar os tenets da VCNdC diminuirá necessariamente a relevância da NdC no EC - o amplo e importante trabalho de Lederman (2007) mostra que, mesmo durante anos em que a HFC e a NdC não faziam parte integralmente ou substancialmente nos currículos estadunidenses, estes temas não deixaram de ser reconhecidos como importantes entre pesquisadores e professores. Embora pareça contraditório defender este afastamento, depois de incontáveis trabalhos ao longo de anos direcionando escrutínios no objetivo de uma inclusão mais efetiva e explícita da HFC e NdC nos currículos (isto é, visando um reconhecimento oficial), não deve-se cair em armadilhas. Os elementos levantados nas seções anteriores nos sugerem que a abordagem por tenets atualmente presente nos NGSS certamente incitará (ou, intensificará) no contexto estadunidense a mazelas já mencionadas (memorização, 'teaching-to-test', empobrecimento curricular, entre outros), reforçando as ideologias neoliberal e cientificista-positivista, os processos de mercantilização da educação e perpetuando discursos hegemônicos e pressupostos ideológicos que pouco fazem para combater as desigualdades sociais (Gandin \& Lima 2016, p.657).

Corrobora indiretamente nosso ponto a análise de Weinstein (2017) acerca dos discursos ambíguos da NGSS, revelando sintonias dissintonias com a ideologia neoliberal. Segundo o autor, o NGSS segue a tradição de outros atos e reformas estadunidenses como o NAR, NSES e NCLB (ibid., p.825) quanto à padronização e direcionamento da educação a interesses mercadológicos. Por outro lado, em diferentes excertos o discurso do documento sugere e incentiva modestamente discussões que toquem as relações entre ciência e sociedade - reconhecidamente uma das mais antigas defesas da área de pesquisa em EC. O aquecimento global é repetidamente mencionado ao longo do documento, e tem seu próprio espaço nos guias de trabalho para professores:

Alterações climáticas globais:

Como se modelam e predizem os efeitos das atividades humanas no clima da Terra? As mudanças climáticas globais, que são conduzidas tanto pelos fenômenos naturais como pelas atividades humanas, podem ter grandes consequências para todos os sistemas de superfície da Terra, incluindo a biosfera (...). Os seres humanos são agora tão numerosos e dependentes de recursos que suas atividades afetam todas as partes do meio ambiente, desde o espaço exterior e a estratosfera até o oceano mais profundo. No entanto, ao usar 
modelos científicos preditivos, os humanos podem antecipar mudanças de longo prazo de forma mais eficaz do que nunca (...) (apud ibid., p.830).

Oportuno citar que a terceira versão BNCC no que tange o ensino médio apresenta uma chamada 'Competência Específica’ que também toca a questão ambiental - sem, no entanto mencionar o termo 'aquecimento global' (Brasil 2018, p.540):

Analisar fenômenos naturais e processos tecnológicos, com base nas relações entre matéria e energia, para propor ações individuais e coletivas que aperfeiçoem processos produtivos, minimizem impactos socioambientais e melhorem as condições de vida em âmbito local, regional e/ou global.

Nesta competência específica, os fenômenos naturais e os processos tecnológicos são analisados sob a perspectiva das relações entre matéria e energia, possibilitando, por exemplo, a avaliação de potencialidades e de limites e riscos do uso de diferentes materiais e/ou tecnologias para tomar decisões responsáveis e consistentes diante dos diversos desafios contemporâneos. Dessa maneira, podem mobilizar estudos referentes a: estrutura da matéria; transformações químicas; leis ponderais; cálculo estequiométrico; princípios da conservação da energia e da quantidade de movimento; ciclo da água; leis da termodinâmica; cinética e equilíbrio químicos; fusão e fissão nucleares; espectro eletromagnético; efeitos biológicos das radiações ionizantes; mutação; poluição; ciclos biogeoquímicos; desmatamento; camada de ozônio e efeito estufa; entre outros.

No caso específico do NGSS, apesar da menção e da suposta importância dada ao tema (aquecimento global), questões mais profundas e esclarecedoras não são levadas em conta. Os conflitos existentes entre as pesquisas científicas, os interesses políticos e as empresas ligadas a combustão de produtos derivados do petróleo - que compõem talvez o verdadeiro cerne do debate acerca do aquecimento global - não são sequer mencionados na parte tocando à educação científica. De fato, segundo Weinstein (2017, p.830), o NGSS não conecta em nenhum momento o poder político de tais empresas e suas largas fortunas, e isso acaba por transmitir uma visão (ideológica) específica sobre a ciência, corroborando nosso ponto. A sugestão, ao fim do excerto, que o problema do aquecimento global pode ser lidado apenas cientificamente é gritantemente ideológica e recai ao alerta de Mészáros (2005) - de que seria tão inócuo (e ideológico) culpar a ciência pelo capitalismo quanto julgá-la capaz de resolver sozinha todos os males que existem. Caso os conflitos apontados fossem pelo menos mencionados, não 
necessariamente a complexidade advinda traria ainda mais dificuldades aos professores imersos na realidade das salas de aula, e estaríamos caminhando em direção à inclusão de conflitos no currículo (Apple 2004). Em suma, ainda com apelos ambientalistas supostamente progressistas, no fim das contas o NGSS acaba por "produzir uma rede neoliberal de práticas de auditoria - como os testes padronizados - os quais irão, no fim das contas, rotular os estudantes como fracassos e assim produzir populações descartáveis” (Weinstein 2017, p.831). Infelizmente, um diagnóstico crítico do caso da terceira versão da BNCC nesta questão específica não é mais otimista que o NGSS.

Do ponto de vista político, o falso dilema apontado anteriormente se mostra como uma questão de escolha - entre coadunar ou não com as ideologias neoliberal e cientificistapositivista. Com efeito, a aproximação da HFC e NdC ao EC sempre teve também facetas políticas (isto é, se consentirmos que escolhas e atitudes educacionais são escolhas e atitudes políticas), ainda que em discursos ideológicos (intencionais ou não) sobre estas temáticas elas não transpareçam. A consciência disto foi raramente explicitada na literatura especializada da HFC e NdC no $\mathrm{EC}^{52}$. De qualquer forma, certamente a escolha por uma contraideologia à ideologia do não-conflito é, de um ponto vista crítico, um caminho mais justo a se defender. Do ponto de vista dos referenciais teóricos deste trabalho, a alternativa resume-se em grande medida a uma escolha politicamente conservadora, ideológica, a de aceitarmos acriticamente o preço da presença da NdC como hoje apresenta-se no NGSS - e, talvez num futuro não muito distante, em outros documentos curriculares como no Brasil, dada a influência das políticas educacionais estadunidenses sobre as brasileiras, e também a força que alguns grupos de pesquisadores (como McComas e Lederman) têm no EC.

Está além de nosso escopo fornecer neste texto uma alternativa concreta e 'final' aos tenets da VCNdC, pelo menos em espírito semelhante a esta e outras presentes na literatura - o que seria, por sinal, insuficiente, dada a natureza estrutural dos problemas que orbitam a questão. Enfatizamos novamente que trocar a forma da sistemática de

${ }^{52}$ O trabalho de Tate (2001) é um dos poucos trabalhos que associa a educação científica (em particular o ensino de $\mathrm{NdC}$ ) com questões sociais. Em suma, o autor argumenta que a questão de acesso a um EC de qualidade, tanto a possibilidade como sua concretização em si, é uma questão social de direitos civis - o que, outrora, era associado somente à 'compartilhar espaços', referindo-se à delicada questão racial no contexto estadunidense. É justo citar também o trabalho de Yacoubian (2013) acerca da controversa relação entre alfabetização científica e reprodução de desigualdades sociais. Praia, Gil-Pérez e Vilches (2007) toca distantemente (e insuficientemente) tais questões. É curioso relatar um raro episódio de ‘confronto político’ na área, o pesquisador Roth (1998, p.1) afirmou que autores na temática de HFC no EC eram "geralmente de direta" associando-os a um espantalho positivista. Em resposta Matthews (2004) mostrou que mesmo autores 'acusados' de positivismo tinham posturas políticas que podem ser consideradas à sua época progressistas. 
definição da NdC para gráficos, tabelas ou matrizes seria inócuo numa realidade em que as políticas educacionais tomam cada vez mais contornos neoliberais, orientando a educação pela voz do mercado, visando a formação de capital humano, privilegiando os interesses dos setores empresariais (Leher \& Vittoria 2016, p.107) com o estudante visto como um consumidor-produto (Karpov 2013, p.32). Entende-se que um problema estrutural demanda, no mínimo, medidas resistivas e contrapostas de mesma natureza; Incapazes disto, pela própria natureza deste trabalho, nos limitamos a: (i) argumentar contra 'abordagens sistemáticas' (listas, matrizes, tabelas e demais tipo de organizações que possam ser enquadradas em testes padronizados por meio de afirmações descontextualizadas ou pobres de crítica) da NdC em currículos, levando as considerações das seções anteriores; (ii) contribuir parcialmente no sentido de fundamentar em teorias críticas de currículo a relevância da HC ao EC, dando-lhe um papel educacional político e criando um apelo resistivo aos processos de mercantilização da educação e ciência.

\section{Argumento}

O conhecimento sobre a ciência deve ter um papel político no ensino de ciências, além dos seus didático-pedagógico e epistemológico já amplamente consolidados na literatura. Deve ser entendido como uma contraideologia às ideologias neoliberal $e$ cientificista-positivista, emaranhadas a processos de mercantilização da educação e da ciência. Uma contraideologia que orbita a noção de conflito - elemento inevitável e fundamental das dinâmicas sociais e criações humanas, como a ciência. A noção de conflito pede a historicidade da ciência no ensino de ciências - e, somado às circunstâncias contemporâneas no campo educacional, impõe restrições quanto à forma de concepção-apresentação do conhecimento sobre a ciência em currículos, especialmente abordagens sistemáticas enquadráveis em testes padronizáveis. Assim, a história da ciência no ensino de ciências deixa de ser propiciamente parcimoniosa, $e$ encontra sua razão de ser naquele campo em enfrentar ideologias que desistoricizam a ciência ${ }^{53}$.

\footnotetext{
${ }^{53}$ Com justiça, seria importante esclarecermos qual HC nos referimos - isto é, a qual(is) corrente(s) historiográfica(s) da ciência -, a fim de que nosso argumento não paire apenas sobre um 'rótulo', sem uma devida explicação acerca do seu 'conteúdo'. A literatura especializada à pesquisa de HFC no EC contém registros de longos e importantes debates sobre qual abordagem historiográfica da ciência - ou, mais curto, qual HC - devemos reservar ao EC. O importante e já citado trabalho de Brush (1974) nos lembra de que os objetivos educacionais em questão condicionam a abordagem da HC a ser considerada. Pois, a título de exemplo, usar excertos de história da ciência focados em 'grandes nomes', em tons hagiográficos e
} 
desprezando os variados contextos envolventes à construção e desenvolvimento do conhecimento científico - algo ainda muito comum em livros didáticos do ensino básico-, além de mostrar desconhecimento de considerações básicas sobre historiografia da ciência e importantes tendências desta surgidas nos últimos decênios (Martins 2001), acaba por reforçar a ideologia cientificista-positivista. A resposta à questão de quais abordagens de HC alinha-se com nosso argumento, entendemos, não por ser desarticulada da resposta à questão sobre quais abordagens de FC alinham-se com nossos argumentos - pois, parafraseando Lakatos (1970), uma HC sem uma FC é cega. De qualquer forma, naturalmente não é qualquer abordagem da HC no EC que se alinha aos nossos argumentos. Por outro lado, as restrições não são exageradamente inibidoras. Como ficará mais claro nos próximos capítulos, nossos argumentos são ortogonais a visões cientificistas positivistas e também a posturas relativistas epistêmicas. Isso inclui, por exemplo, leituras demasiadamente relativistas dos cânones de Kuhn - tais como de socioconstrutivismos relativistas - (ver Condé 2017), vertentes do chamado 'Programa Forte' da sociologia da ciência, alguns autores associados a tendências pós-modernistas relativistas, entre outros. Longe de inaugurarmos alguma abordagem inédita ou 'panaceia' sobre HFC e NdC no EC, apresentaremos em capítulos seguintes, na forma de ensaio e esparsamente, um conjunto de caracterizações que dialoguem com nossos argumentos. 


\section{Conhecimento sobre a ciência como um metaconhecimento poderoso}

A etimologia não revela o sentido real das palavras, mas pode servir para cutucar o pensamento ou ajudar a demarcar territórios. O “professor” é também quem “educa”. De “ex” + “ducere”, “conduzir para fora”, o “professor” ou “educador” é quem leva o outro além ${ }^{54}$.

O segundo argumento desta tese se baseia em obras recentes do sociólogo da educação Michael Young - em especial no conceito cunhado pelo autor de conhecimento poderoso. Para se compreender minimamente esta (recentemente elaborada) concepção de Young é preciso resgatar, ainda que muito brevemente, alguns pontos vernais de sua trajetória acadêmica e entender de início o que seria o conceito aparentemente oposto ao citado - o 'conhecimento dos poderosos' 55 .

Como comentado rapidamente em capítulos anteriores, Young teve um papel central na publicação de Knowledge and Control (KAC) (1971), obra que impulsionou novas visões sobre a sociologia da educação, que posteriormente ficou conhecida como Nova Sociologia da Educação (NSE) (Galian \& Louzano 2014, p.1111) ${ }^{56}$. De forma resumida, pode-se afirmar que a NSE visava substituir a 'velha' sociologia da educação - que explicava o insucesso escolar em termos de desigualdades de classe, da falta de background cultural, ou, da incapacidade de educar-se pelo 'currículo oficial'-, argumentando-se que era a estrutura do currículo acadêmico - por meio "suas disciplinas individuais separadas, suas hierarquias de conhecimento válido e sua exclusão do conhecimento não escolar”- a principal fonte de desigualdade e exclusão na educação (Young 1989, p.34). Foi deste ímpeto político e intelectual, segundo Young, que se

\footnotetext{
${ }^{54}$ De autoria de Sofia Nestrovski.

Link para fonte: https://www.nexojornal.com.br/lexico/2018/05/06/Sobre-aquele-que-fala-e-educa.-E\%С3\%A9-capaz-de-levar-o-outro-

al\%C3\%A9m?utm_campaign=Echobox\&utm_medium=Social\&utm_source=Facebook\#link_time=152564 8582, acesso maio de 2018.

${ }^{55}$ Tratemos uma definição mais adequada do conceito de conhecimento poderoso em seção posterior neste capítulo.

${ }^{56}$ A obra surgiu das atas de uma conferência da British Sociological Association em 1968 e de uma pós-conferência em 1970 com contou com nomes como Basil Bernstein e Pierre Bourdieu, ao qual ficou estabelecido que Young seria o editor (Morgan 2015, p.15).
} 
consolidou o conceito de 'conhecimento dos poderosos' - isto é, o conhecimento selecionado pelas classes dominantes, que por sua natureza perpetuaria as estruturas de poder na sociedade, entre outras razões, por excluir o conhecimento de classes oprimidas. Este conceito teria parcialmente origens, segundo Young, na famosa colocação de Marx e Engels em Die deutsche Ideologie (1845-6) de que “'as ideias dominantes em qualquer sociedade são sempre as ideias da classe dominante"” (apud Beck 2013, p.179). Assim, para a NSE, conhecimento dos poderosos se referia à camada social que define e domina o acesso ao conhecimento (idem).

A proposta da NSE em se compor uma 'nova esquerda' educacional britânica reflete a grande ramificação da esquerda britânica no momento posterior, o que foi entendido como fracasso dos governos do Partido Trabalhista inglês de meados do século passado (Morgan 2015, p.10). A frustração com o 'High Hopes' investido neste partido nos decênios pós-guerra foi ressonante aos movimentos sociais e estudantis - como o já citado em maio de 1968 na França. O relato pessoal de Young sobre o período é esclarecedor sobre os rumos tomados pelo próprio sociólogo:

\footnotetext{
Era um período que realmente começou pra mim no final dos anos 1950 e no começo dos 1960 com muito otimismo e a sensação de possibilidades daquela época. Muitos de nós na esquerda não éramos apenas oposição às inumanidades do capitalismo mas também acreditávamos que o socialismo era uma possibilidade futura real; histórica, pensávamos, estava 'do nosso lado'. Era essa crença na mudança das coisas que me levou à política, e depois ao meu pensamento sobre currículo (Young apud ibid., p. 11).
}

Esta foi a chamada fase socioconstrutivista de Young (Sharp apud ibid., p.9) - ou, na análise de Lopes e Macedo (2011, p.78), fase “antipositivista, questionadora de possíveis definições a priori para o conhecimento". Este questionamento implicaria na opção da ética e política como instrumentos de validação de saberes e conhecimentos. À época, para Young, "um conhecimento é valido e legítimo se tem capacidade de contribuir para a libertação humana" (ibid., p.79) - isso implicaria na não superioridade dos conhecimentos acadêmicos específicos sobre outros conhecimentos. Young reconhecia o relativismo de sua postura, "sendo incapaz de argumentar que uma forma de conhecimento é 'melhor' que qualquer outra", preferindo defender o comprometimento político de professores para com mudanças radicais (Morgan 2015, p.9). Com efeito, segundo Morgan (ibid., p.12) era comum sociólogos da educação recém-formados à 
época abraçarem o relativismo, rejeitando a superioridade do currículo acadêmico. Anos depois Young (1989, p.31) considerou que tal radicalismo intelectual, característico da emergência da NSE, devia mais a uma "ingenuidade política nascidas das aspirações da década de sessenta que a teoria e as pesquisas sistemáticas”.

As reações a KAC à época, especialmente no Reino Unido, foram diversas, abrangendo diferentes pontas do espectro político. Young (1989, p.32) comenta que a 'esquerda tradicional' britânica, associada ao Partido Comunista, numa resistência gramsciana, criticou a NSE por ameaçarem o acesso ao currículo acadêmico - pauta que apenas começava ser contemplada num esforço deste setor para com políticas de acesso. Argumentos de que a NSE ameaçava os pilares da educação democrática e igualitária e que incentivava um ‘apartheid educacional' não eram raros em periódicos da área (idem). De outro lado, a reação daquilo que Young chama ‘direita política’ da época tinha um forte caráter ideológico, com discurso bastante raivoso e antagonista:

(...) havia a "direita politica", então, diferentemente, de hoje, um grupo bastante marginal na Inglaterra, particularmente em educação. O melhor exemplo [de reação a KAC] é a publicação, em 1977 (...) de um panfleto intitulado $A$ Penetração Marxista e Radical: O Ataque à Educação Superior. Falava de professores chegando às escolas com "Knowledge and Control em suas veias" prontos para “preparar a juventude britânica para o assalto Trotskysta”. Menos politicamente carregada, mas não menos ansiosa foi a reação de filósofos educacionais, e mesmo de alguns sociólogos. Esses escreveram artigos em jornais e revistas com títulos tais como "o caos do relativismo" (...) e “Knowledge out of Control” (...) (ibid., p.31).

É curioso como o discurso de tal panfleto é semelhante aos clamores de defensores da EsP, ainda que separados por dezenas de anos, acerca da suposta 'doutrinação marxista esquerdista’ feita por professores (Gadotti 2016, p.152) ${ }^{57}$.

O contexto político e econômico da Inglaterra nos anos 1970 em diante veio a moldar o desenvolvimento da NSE (Morgan 2015, p.5). Nas palavras de Young, o otimismo em mudanças característico do movimento cedeu lugar a um sentimento de derrota nos anos

\footnotetext{
${ }^{57}$ Gadotti (2016, p.155) menciona um episódio brasileiro que podemos entender como um análogo muito mais grave - à publicação do panfleto mencionado por Young. Seria a extinção do Programa Nacional de Alfabetização de Paulo Freire, que havia sido criado em 21 de janeiro de 1964 (ainda no governo de João Goulart), em 14 de abril do mesmo ano (pelo presidente militar em exercício Ranieri Mazzilli, já na ditadura instaurada após o golpe civil-militar de primeiro de abril). Gadotti (idem) menciona que este presidente justificou o ato para "preservar as instituições e tradições de nosso País”, como se sabe, sobre um retalho propagandístico altamente anticomunista e antissocialista.
} 
1970 e 1980 com o colapso de movimentos progressistas no ocidente, e também pelas frustações em construir sociedades socialistas estáveis (ibid., p.11). Especificamente no contexto britânico, isto se refletia nas reeleições do Partido Conservador na década de oitenta - a era Thatcher, ou, como também ficou conhecida, 'a longa década' conservadora - e também na desconfiança popular para com o progressivismo, manifesto mesmo nas classes trabalhadoras (ibid., p.17).

Anos depois do início da NSE, Young (1989, p.33) apontou que uma de suas falhas foi negligenciar questões de gênero e raça - e, apesar da importância no movimento em esclarecer conexões entre poder, currículo e conhecimento, Young (ibid., p.32) reconheceu que alguns de seus críticos (particularmente os avessos ao relativismo) estavam, em seu julgamento, corretos. Ao seu olhar, a NSE ao entender o currículo como poder ideológico não deixava nenhum currículo como alternativa, seja baseado em experiência (como a noção de competências) ou 'menos conteudista' (ibid., p.34). Assim, somando o sentimento de derrota na 'velha' esquerda britânica e os sucessivos governos do Partido Conservador inglês, a partir dos anos 1980 Young inicia sua mudança de perspectiva explorando as tensões do que chamou 'currículo do passado' - baseado nas formas de conhecimento designadas para um sistema escolar elitista - e 'currículo do futuro’ - fundamentado no reconhecimento que o conhecimento é socialmente construído (Morgan 2015, p.13).

Nos anos 1990 - no contexto da ascensão do neoliberalismo e de políticas ‘modernizadoras' conservadoras na educação alinhadas com o setor produtivo (e, também, de apelos 'restauracionistas' em prol de uma visão romântica da alta cultura britânica), contando ainda a incorporação do discurso de 'modernização' pela 'nova' esquerda tradicional inglesa - Young publicou seu livro The Curriculum of the Future (1998), concomitante a vitória nas eleições britânicas do Novo Partido Trabalhista britânico sob a liderança de Tony Blair (ibid., p.14). Posteriormente, com a desilusão com o desenvolvimento subsequente do projeto educacional deste governo, Young se aproximou de perspectivas culturais do conhecimento (ibid., p. 17) - paralelamente, a sociologia da educação tornava-se em geral mais concentrada em questões de identidade ou análises da governamentalidade do neoliberalismo (ibid., p.20). Foi também neste período que Young acompanhou de perto as (rápidas) transformações curriculares na África do Sul (Hoadley 2015), e posteriormente o primeiro currículo do período pósapartheid, já nos anos 2000. 
Envolvido diretamente nas políticas curriculares sul-africanas - as quais eram bastante influenciadas pelo 'espírito' da NSE, flertando com formas radicais de construtivismo, defendendo o localismo na construção dos currículos e da escolha de conteúdos, e, principalmente, enfraquecendo as fronteiras disciplinares a uma ênfase na integração curricular (ibid., p.737) -, Young deparou-se com fragilidades da NSE outrora defendida pelo sociólogo. Como ele próprio relata (Young 2015, p.821):

\begin{abstract}
Vi com meus próprios olhos na África do Sul as consequências desastrosas de introduzir políticas curriculares que falharam em levar em conta seriamente a questão do conhecimento. De interesse particular para mim, era que o novo currículo que fundava-se num conceito radical de resultados que não especificava requerimentos de conhecimentos, era baseado numa crítica do conhecimento que não era tão diferente da posição socioconstrutivista que eu tinha vinte anos atrás em Knowledge and Control. Aquilo me chocou. Foi aqui que dois colegas muito respeitados [Moore e Muller] e outros amigos argumentaram que a lógica do meu livro Knowledge and Control, o qual estabeleceu a minha reputação enquanto sociólogo da educação, tinha tido precisamente o efeito oposto ao qual se pretendia. Ao invés de propiciar o conhecimento como fonte de liberdade, meu livro propiciou, pelo menos como foi interpretado, que se devia livrar os estudantes - principalmente os mais desavantajados - do conhecimento. Foi exatamente isso que aconteceu através da introdução do currículo baseado em resultados na África do Sul, que negligenciou o conhecimento.
\end{abstract}

Em suma, o que Young verificou no exemplo da África do Sul foi um reflexo do movimento global em direção a padrões acadêmicos, avaliadores e quantificadores, que levou progressivamente não só ao desaparecimento de questões associadas ao conhecimento nas políticas educacionais e de currículo, mas também reduziu o propósito da educação pública a parâmetros econômicos - além de fomentar fragmentação da escola pública, a dissolução das fronteiras entre público e privado, e o declínio da profissão de professor (Deng 2015). Tratam-se de diagnósticos muito similares a de outros autores acerca da mercantilização da educação discutidos no capítulo anterior ${ }^{58}$. É nesse sentido que se pode então argumentar que currículos híbridos - uma bandeira bastante defendida em especial por teóricos de currículo pós-modernos (ver Doll Jr 1993; Usher \& Edwards 1994; Pourois \& Desmet 1997) nos anos 1990 -, são utilizados pelo que

\footnotetext{
${ }^{58}$ Oportuno citar que Zavale (2013) identifica tais diagnósticos no caso das reformas educacionais (neoliberais) no país africano Moçambique nas décadas de 1990 e 2000, o que reforça que a mercantilização da educação não se limita a um fenômeno europeu ou do continente americano.
} 
chama (utilizando uma categorização de Bernstein (2000b) de 'instrumentalistas neoliberais' como ferramentais ao gerencialismo educacional (Wheelahan 2010). Wheelahan (ibid), neste sentido, esclarece que o currículo centrado em competências, bastante influente em países como Austrália, Inglaterra, África do Sul e Nova Zelândia e, pode-se incluir também, discriminando apropriadamente os contextos, o Brasil -, é um resultado do casamento de correntes genericamente chamadas de construtivismo e o instrumentalismo neoliberal.

Segundo Young (apud ibid., p.7), alguns elaboradores de políticas favorecem "currículos híbridos porque eles questionam a autoridade e a autonomia dos produtores de conhecimentos de especialistas", e ainda porque "propicia a estes últimas uma maior abertura a medidas de accountability" ${ }^{59}$, desviando os objetivos da escola para com justiça social em direção à formação de capital humano. Finalmente, para Young, o foco de algumas políticas em prol do hibridismo curricular:

(...) está na sua 'relevância’ para o local de trabalho, medido pelo ‘impacto’ da aprendizagem sobre os resultados no local de trabalho, que é estreitamente definido como relacionado diretamente com tarefas, papéis ou problemas do local de trabalho, em vez de equipar os alunos com o conhecimento que eles precisam para interagir com a sociedade mais amplamente (apud idem)

Mais uma vez, como apontado por Morgan (2015), a mudança de perspectiva de Young nos anos 2000 correlaciona-se às mudanças também no governo britânico e suas políticas educacionais - e não pode, assim, sua mudança ser reduzida ao que Silva (2010, p.73) pejorativamente classificou de uma virada a uma postura mais "técnica $e$ burocrática”. O primeiro ponto, a redução economicista da educação na Inglaterra, que é explícita na afirmação do então primeiro ministro britânico Tony Blair de que "políticas educacionais são a melhor política econômica” (apud Young 2016b, p.2). Em segundo lugar, as progressivas mudanças curriculares inglesas desde o primeiro currículo nacional em 1988, que culminaram em 2007 na introdução de políticas de avaliação com base no modelo de competências em um contexto de fundo em que a obrigatoriedade se resumia a Matemática, Inglês e ensino religioso, como possibilidade de cursos vocacionais (ibid., p.7). Isto é, na ótica de Young um progressivo enfraquecimento do currículo baseado no conhecimento, traduzido na centralização do currículo nos interesses e experiências dos

\footnotetext{
${ }^{59}$ Novamente, como discutido no capítulo anterior, este é dos traços do processo de mercantilização da educação e da ciência, como apontado no capítulo anterior.
} 
estudantes - uma demanda mais ou menos geral de movimentos ingleses associados à esquerda (Young 2015, p.265).

Tal mudança de Young - que de forma alguma foi espontânea - traduz-se no título de sua obra publicada em 2008 (Young 2016a), reunindo trabalhos anteriores focados na tese do currículo guiado pelo conhecimento: Bringing Knowledge Back In, e o subtítulo, From Social Construtivism to Social Realism in the Sociology of Education. Seu conteúdo simboliza o abandono de formas radicais de socioconstrutivismo, que negam qualquer chance de progresso, verdade e conhecimento, recaindo ao que chama de 'pósmodernismo nihilista nietzschiano', ao mesmo tempo, ele rejeita epistemologias positivistas que negam o caráter social e humano do conhecimento e atribui-lhe neutralidade (idem). Não nega, contudo, importantes lições aprendidas com a NSE nos anos 1970 - como o fato de que "conhecimento não é simplesmente dado e ensino não é transmissão, pelo menos não num sentido mecânico” (Young 2015, p.827) - e, também, 'contralições' - como a ideia de que a natureza social do conhecimento não necessariamente mina sua objetividade ${ }^{60}$ (idem). Sem a NSE, argumenta, não seria possível chegar à sua tese atual de emancipação e justiça social (Young 2016a, p.18). De fato, mais do que uma crítica ao 'socioconstrutivismo extremo' - ao qual confessa ter feito parte na eclosão da NSE -, Young argumenta que nesta nova fase seu moto principal é "o argumento pelo acesso ao conhecimento como propósito principal das escolas" (Young 2015, p.829).

Num movimento contrário a correntes majoritárias atuais da área, Young (2016) identifica que há hoje uma crise em teorias de currículo referente à perda do 'objeto' destas: o próprio conhecimento, e também sua aquisição. Argumenta, por exemplo, que teorias críticas de currículo como o neomarxismo de Apple - ainda que suas análises tenham se estendido a importantes estudos feministas, antirracistas, pós-estruturalistas e outros -, contribuem para aquela crise (ibid., p.832). Em absoluto, Young afirma que uma teoria de currículo deve de início diferenciar o que chama de 'conhecimento do dia-a-dia' daquele que cabe ao currículo - sendo esta diferenciação parte da teorização (ibid., p.822). Também, deve se ocupar de questões epistemológicas - tal como a (problemática e complexa) noção de verdade, um dos fundamentos da autoridade docente segundo o autor - e sociológicas - como o clamor de determinada comunidade de especialistas em ciência acerca de alguma 'verdade’ garantir que esta é o melhor que temos (até então)

${ }^{60}$ A objetividade do conhecimento científico será tópico de discussão na seção 3.4. 
para oferecer às gerações futuras (idem). Este é, salvo algumas ressalvas, também o ponto de Arendt (1993).

Ao elaborar tal diagnóstico quanto à crise currículo, Young mostra-se resistente à tese de que papel principal da escola deva ser "promover o bem-estar e o florescimento humano”, dado que este seria a papel de outras instituições civis ou públicas, como a família (no sentido mais amplo possível) e o Estado (Young 2014a, p.7). Obviamente, essa resistência não significa afirmar que a escola deva promover os opostos de 'bemestar' e 'florescimento humano' - isto é, não se nega estes objetivos em si, mas sua prioridade nas funções da escola. Young argumenta que o papel principal da escola deve estar na direção daquilo que mais a caracteriza: prover a todos os estudantes acesso ao conhecimento (idem). Todavia, para o autor, na questão do que deve estar presente nos currículos, não se trata de qualquer conhecimento:

O que unicamente as escolas podem fazer pelos estudantes, e é isto o motivo do currículo ser central para todos nós em educação, é oferecer oportunidades para estudantes de todas as idades em ir além das experiências que eles trazem para a escola, e adquirir um conhecimento que não está estritamente ligado à experiência [do dia-a-dia dos estudantes]. Trata-se de um conhecimento (relativamente) livre de contexto, o qual alguns de nós descrevemos como ‘conhecimento poderoso’ (...), e o qual, nas palavras de Basil Bernstein, permite aos estudantes 'pensar o impensável e o ainda-não-pensado’ (ibid., p.17).

Como será novamente discutido em seções posteriores, Young fundamenta o conceito de conhecimento poderoso em uma nova teoria sociológica do conhecimento e educação. Esta, de princípio, põe-se avessa a duas posições ideológicas opostas, que segundo o autor pairam a educação atualmente, que chama respectivamente de tradição neoconservadora e tradição técnico-instrumentalista (Young 2016a) ${ }^{61}$. Resumidamente, para o autor o neoconservadorismo é em geral desprovido de preocupações epistemológicas sobre o conhecimento, e é inspirado na visão tradicional de que a disciplina discente promove o respeito à autoridade e protege valores tradicionais. Nas palavras do autor:

O problema da posição neoconservadora é que (...), trata 'o que de melhor existe’ [para o currículo] como se fosse algo de dado e não como o resultado,

\footnotetext{
${ }^{61}$ Como se notará, as caracterizações de Young para o neoconservadorismo não são tão distantes daquelas de Apple - salvo os detalhes que, naturalmente, cada autor realiza tais exercícios de caracterização em seus próprios contextos de pesquisa e trabalho.
} 
em qualquer período, de mudanças sociais mais globais, assim como de debates desenvolvidos no interior das disciplinas. Pelo fato de desvalorizarem a natureza social e histórica do conhecimento, os neoconservadores não vêem qualquer necessidade de uma teoria que se refira àquilo que deveria (ou não) constar do currículo, quer se trate deste ou daquele romance ou de novas disciplinas. Para eles o cânone da literatura inglesa e as disciplinas escolares tradicionais existem, simplesmente, como um dado: eles definem o que é um currículo.

O técnico-instrumentalismo procura direcionar o discurso curricular diretamente às necessidades de mercado, preparando os estudantes para a economia global e competitiva $^{62}$. Nesta última, Young argumenta, o conhecimento e o currículo são um meio, e não um fim em si mesmo (idem). A tradição técnico-instrumentalista teria e tem fundamentado, segundo Young, várias reformas educacionais recentes nos últimos decênios, não-raro associadas aos discursos de desenvolvimento econômico, inclusão, maior participação e promoção social. Poder-se-ia argumentar que, entre estas reformas, incluem-se também aquelas muitas vezes dirigidas por aqueles que Mészáros (2006, p.34) chama de 'reformistas sócio-educacionais esclarecidos', subjetivamente bem intencionados e que "honestamente tentam remediar os efeitos alienantes $e$ desumanizantes do 'poder do dinheiro' e da 'busca do lucro'”, mas que, porém, acabam por não escapar da “auto-imposta camisa-de-força das determinações causais do capital”. Segundo Lopes e Macedo (2011, p.74), tendências curriculares ainda atuais, como o currículo por habilidades e competências - cerne, por exemplo, da terceira versão do BNCC para o ensino básico e médio-, poderiam ser aí incluídas.

Contemporaneamente muitas perspectivas pós-modernistas na educação são também críticas tanto à tradição neoconservadora quanto à técnico-instrumentalista. Neste sentido, como comentando por Young (2016a, p.58), mesmo não sendo a principal via em educação, perspectivas pós-modernistas tendem a ocupar o lugar que de outrora fora de teóricos da NSE e autores de inspiração marxista. Ainda que bastante diversificadas, estas

\footnotetext{
${ }^{62}$ Voltaremos a discutir estas tradições nas seções 3.2 e 3.3. As categorizações de Bernstein (2000b), as quais inspiraram Young, fornecem esclarecimentos acerca de caracterizações específicas daquelas. É oportuno citar que por vezes o técnico-instrumentalismo esteve ligado a apelas de aproximação da indústria à educação. Na seção intitulada 'As necessidades da indústria', Waddington (1987) argumenta que os currículos escolares do ensino básico não fornecem no geral conhecimentos necessários para as indústrias, algo que seria imprescindível para os chamados países do terceiro mundo mudarem. $\mathrm{O}$ autor afirma com todas as palavras que "o currículo precisa preparar estudantes para as realidades das aplicações industriais da ciência” (ibid., p.221), e enfatizar aspectos relacionados a 'orientação para sucesso', 'inovação', ‘empreendedorismo’ e 'adaptabilidade a mudanças'. Esses discursos, difusos e não concentrados nos debates curriculares, tiveram respaldo em especial no início da década de 1990 (ver Silva 2008).
} 
perspectivas tendem a argumentar que o conhecimento acadêmico é ideológico e elitista, e tomam o relativismo epistêmico como princípio (idem). Tal julgamento é um dos motivos pelos quais Young se mostra bastante crítico às visões pós-modernas e relativistas de conhecimento e de currículo, como veremos em seção posterior. Seu principal argumento contra estas últimas é justamente que as asserções do pósmodernismo e das tradições relativistas sobre o conhecimento na verdade negligenciam justamente o problema que visam resolver - o problema do conhecimento (Young 2008, p.23). Este elemento levado ao currículo reflete exatamente a crise alertada por Young. Ainda, argumenta que o ceticismo radical de muitos autores e ideias pós-modernistas tende justamente a aproximá-las às tradições neoconservadora e técnico-instrumentalista que criticam (Young 2016a, p.58).

Para Young, deve-se resistir à sedução tanto do discurso positivista - ou, da ideologia cientificista-positivista - como também do discurso relativista:

(...) [Ao] argumentar que todo conhecimento deriva parcialmente e potencialmente de interesses autocentrados, o relativismo pode ser visto como uma base superficialmente poderosa em desafiar o que é assumido como as formas dominantes e repressivas de conhecimento de currículos existentes. Relativistas atacam os apelos à objetividade de formas dominantes de conhecimento e, por implicação, defendem as 'vozes' que são negadas ou escondidas. (...). Ao mesmo tempo, ao privilegiar a exclusividade de experiências particulares, eles negam a comunidades oprimidas o acesso a um conhecimento que vai além de suas experiências e que pode ter um papel em permiti-las superar as opressões (Young 2008, p.27).

Apenas as críticas ao conhecimento não fornecem em si nenhuma alternativa curricular concreta (Beck 2013) - algo que foi justamente um dos problemas da NSE segundo Young. A persistência das grandes desigualdades sociais na educação, argumenta o autor, pede uma postura radical a favor do conhecimento, e não o oposto (Young 2011, p.610) uma postura, porém, não recaia nas tradições técnico-instrumentalista ou neoconservadora. De fato, para o autor, uma das dificuldades de estabelecer tal postura reside no fato de que, em geral, “desenvolver uma sociologia da educação que confira ao conhecimento o seu lugar de destaque no currículo deslizam facilmente para um regresso à desacreditada posição neoconservadora” (Young 2016a, p.75). Esta é razão da (nova) abordagem de Young ser não raro mal interpretada e associada ao conservadorismo - ou, no contexto especificamente britânico, entendida como uma apologia às políticas do 
Partido Conservador inglês na década de 2000, o que Young nega enfaticamente em diferentes momentos.

O dilema educacional posto sobre a questão do currículo - currículo ‘dado’ × currículo 'não dado' (fruto de disputas e exclusões entre certos tipos conhecimento) -, levaram Young (2016a, p.20) ao trabalho nada trivial de vincular coerentemente questões epistemológicas, sociológicas, políticas e educacionais. Sua resposta ao dilema culminou na construção de uma nova teoria social do conhecimento e educação, a qual chamou de Realismo Social (RS). O RS, como será discutido em seção seguinte, é uma tentativa bastante recente de Young e outros e está em constante construção e revisão (Guile, Lambert \& Reiss 2018). Longe de adotarmos acriticamente o RS, consideraremos, porém, seriamente o clamor de Young de que é preciso uma teoria de conhecimento ao currículo, e que o pensar filosófico sobre a ciência - ou, simplesmente, a FC - no EC precisa ter um papel também político e social - assim como a HC, conforme defendemos no capítulo anterior. E, dado que este papel deve associar-se a um compromisso de justiça social e combate à desigualdade, neste sentido não será qualquer teoria do conhecimento que será interessante - ou, qualquer FC -, para o EC.

A compreensão da defesa do currículo guiado pelo conhecimento ${ }^{63}$ e o seu papel político e social permite, por sua vez, entendermos a preocupação de Young e outros acerca da presença do relativismo na educação. Suas críticas vão de encontro às alegações daquilo que chamam 'discurso das vozes' de que a ciência é um “saber especializado ocidental, branco e masculino" (Young 2016a, p.31), ao relativismo epistêmico sobre a noção de verdade, da redução do conhecimento científico à ideologia (cientificista) positivista, e também às interpretações pouco cuidadosas de autores (classificados como) pós-modernos de educação sobre obras de Kuhn e outros (idem). O frequente argumento de que o conhecimento científico é de natureza social é não raro utilizado para defender o relativismo - como se a natureza social do conhecimento lhe tirasse toda e qualquer objetividade, ou, como se houvesse uma demanda oculta em tais defesas (muito semelhante ao ‘espantalho’ positivista que criticam) de que 'para que o conhecimento seja conhecimento' este precisa ser a-social (ibid., p.79). Como discutiremos, Young, em contrapartida, argumenta que é justamente o caráter social da ciência que torna possível sua objetividade (ibid., p.80) - e, que a defesa desta não implica negar, por exemplo, “que a produção e transmissão do conhecimento está sempre enredada num complexo

\footnotetext{
${ }^{63}$ O que é diferente da ideia de ‘currículo centrado em conteúdos’, como será discutido na seção 3.2.
} 
conjunto de interesses sociais antagônicos e de relações de poder” (idem). O problema reside, em suma, no reducionismo ideológico de ciência a relações de poder e interesse.

Pode-se entender que assim como a mercantilização da educação e do conhecimento era o problema principal a ser considerado no segundo capítulo, neste capítulo é o relativismo na educação e desvalorização da ciência - ainda que, no fundo, ambos relacionem-se. Especificamente no contexto educacional inglês, Young identificou como este problema se manifesta na progressiva diminuição do papel do conhecimento na base comum curricular, por exemplo, em prol de demandas da tradição técnicoinstrumentalista - direcionando a educação aos interesses do mercado. No contexto brasileiro podem-se notar semelhanças com a lei de reforma do ensino médio e a proposta da última versão do BNCC para o ensino médio fundada nos conceitos de habilidades e competências (ver Brasil 2018, Freitas 2018). Paralelamente à desvalorização do papel do conhecimento nos currículos, vê-se o constante uso de discursos ideológicos cientificistapositivistas justificando reformas curriculares e políticas educacionais de cunho neoliberal, como testes padronizados e 'incentivos', como foi discutido no capítulo anterior. De fato, Young (ibid., p.54) argumenta que uma teoria de conhecimento ao currículo é importante para revelar e enfraquecer a retórica de tais políticas - em especial a de testes e metas visando 'qualidade' -, assim como o mau uso delas - e, ainda, no caso específico das políticas de testes, “como se transformam em fins em si mesmos, em vez de constituírem meios para se atingirem propósitos mais amplos” (idem).

No sentido delineado acima, a luta contra a desvalorização da ciência e o relativismo, portanto, é uma luta não só no domínio filosófico, mas também no social e político. A crítica às defesas relativistas radicais em correntes pós-modernistas na educação, assim, torna-se indispensável - e urgente, dado que tais defesas, talvez ao contrário da ideia original de seus proponentes, podem entrar em ressonância às ideologias neoliberal e cientificista-positivista. Por outro lado, tais correntes, segundo Young, desconsideram "possibilidades de o currículo acadêmico contribuir para a libertação dessas pessoas [estudantes], bem como potencializar sua compreensão do mundo que vivem” (Lopes e Macedo 2011, p.80). Em suma, para Young, a luta contra desvalorização da ciência e do que chama conhecimento poderoso no currículo é uma luta contra o niilismo, uma das saídas possíveis dentro do relativismo epistêmico: 
deferência para com a experiência e a sua crítica dos saberes especializados), também se tornam sedutores, especialmente para quem se sente mais frustrado com os continuados fracassos do sistema existente. Ao rejeitar a possibilidade da existência de qualquer conhecimento objetivo, a lógica da sua posição é, na melhor das hipóteses, niilista (Young 2016a, p.53).

Os problemas que o relativismo traz para o EC não são difíceis de reconhecer. Um exemplo interessante concerne o conhecimento científico acerca do formato do planeta Terra. O romancista russo de veia científica Isaac Asimov (1989) apresentou pouco antes de falecer um curto, porém provocante, artigo sobre a problemática da 'relatividade do errado' - em alguns pontos, interessantemente atual. Uma das origens de tal problemática, argumenta o autor, resume-se a uma aparente 'versão popular' do conhecido argumento da meta-indução pessimista de Laudan: “em cada século as pessoas acham que entenderam o universo em sua plenitude, e em cada século elas são desmentidas. Segue disto que podemos afirmar que nosso 'conhecimento' moderno está errado” (ibid., p.36). Pautado neste raciocínio, alguém poderia argumentar que embora hoje se considere a Terra como 'esférica', é perfeitamente possível que a concebamos como "cúbica no próximo século, e um icosaedro oco no próximo, e uma rosquinha no seguinte" (ibid., p.42) - um tipo de defesa ressonante a discursos pós-modernos relativistas (Grant 2011, p.99). A falha neste pensamento para Asimov estaria nos absolutismos de 'certo' e 'errado' - ou, de que algo ou é perfeitamente certo ou completamente errado. À luz da discussão feita no capítulo anterior, tem-se que os pensamentos absolutistas de que ‘a ciência está completamente certa' ou 'a ciência está completamente errada' são igualmente falhos - e ideológicos, sendo o primeiro referindose à ideologia cientificista-positivista e o segundo ao relativismo epistêmico ${ }^{64}$. Ou, tanto a valorização ideológica da ciência como sua desvalorização ideológica são, com a permissão de estendermos o exercício de Asimov, indesejados - especialmente no EC.

Entendemos que tal alerta é relevante se, tendo ainda como pano de fundo em especial a questão do formato da Terra, atentarmos ao crescimento do número de simpatizantes da concepção do formato plano da Terra e seu (ainda pouco perceptível) impacto no EC (Lang 2017). Ainda que os argumentos dos chamados 'terraplanistas' sejam dificilmente aceitáveis ou rigorosamente científicos - por sinal, estes são não raro amparados por visões religiosas fundamentalistas (ibid., p.8) -, o alargamento desta 'comunidade'

\footnotetext{
${ }^{64}$ A natureza ideológica do relativismo epistêmico será objeto de discussão na seção seguinte.
} 
particularmente em mídias sociais revela um aspecto da supramencionada desvalorização ideológica da ciência ${ }^{65}$. Asimov procura argumentar que tanto a ideia de Terra esférica

\begin{abstract}
${ }^{65} \mathrm{O}$ 'caso Terra plana' lembra os pendulantes e controversos debates sobre a teoria da evolução e suas 'refutações' e o impacto disso no ensino de biologia e educação em geral. Isto, entendemos, merece uma nota de rodapé relativamente longa (e, inevitavelmente incompleta, pela complexa e vastidão desta problemática). Em Education the 'Right Way', de Apple (2006) analisa criticamente o crescente interesse mercadológico-neoliberal sobre a educação, assim como o levante conservador moralista, radicalismo religioso, desvalorização da ciência e a visão utilitarista sobre o conhecimento. Com algumas ressalvas, podemos também assim caracterizar parte do conjunto de interesses de setores de direita a assumirem numerosos cargos políticos no Brasil a partir de 2019. Um exemplo pontual pode ser encontrado em uma entrevista no dia 15 de outubro de 2018 a um dos conselheiros sobre educação do candidato à presidência eleito pelo pleito no mesmo ano, no qual ele expressou suas opiniões sobre os 'novos' direcionamentos destinados à educação brasileira (Entrevista realizada por equipe do jornal Estadão. Disponível em: https://politica.estadao.com.br/noticias/eleicoes,e-preciso-nova-bibliografia-para-escolas-diz-assessor-debolsonaro-para-a-

educacao,70002547417?fbclid=IwAR05i38_GK XxoREc4NF0V4Vn3T9F5y_i0ttkXnNtALOcT4rVEVaG XmRuZQ, acesso em outubro de 2018). O conselheiro em questão defende uma 'nova bibliografia' para educação, sem 'ideologia de gênero' e que conte 'a verdade sobre 1964'. No que tange a educação em ciências, em particular a biologia, ele afirmou: "[c]abe citar o criacionismo, mas não cabe querer tratar que o criacionismo não existe. (...) Houve Darwin? Houve, temos de conhecê-lo. Não é para concordar, tem de saber que existiu". Especificamente no contexto educacional estadunidense, como aponta Apple (2006), a 'reação antievolucionista' teve seus altos e baixos. Hellman (1999) recorda as leis de proibição do ensino da teoria de Darwin em alguns estados daqueles pais em diferentes momentos. Fração considerável dos posicionamentos de autores antievolucionistas (muitos deles radicais religiosos) tende a ser do tipo ‘a ciência é completamente errada' (isto é, desvalorização ideológica da ciência) e 'a bíblia é completamente certa' - isto é, um inerrantismo bíblico (Apple 2006, p.126). As celeumas atuais acerca do papel do ensino do criacionismo em escolas estadunidenses geraram (e ainda geram) um espectro desanimador - incluindo currículos estaduais, aparatos legais e administrativos que obriguem a evolução a ser ensinada como 'apenas mais uma possível hipótese' (ao lado do criacionismo), passando por requerimentos de que livrostextos que enfatizem que evolução é uma 'teoria' (no sentido popular, próximo à ideia de 'hipótese' porém com tom pejorativo) e não um 'fato' (no sentido também popular e ingênuo de algo 'pétreo', indiscutível). Somando isto ao resultado de uma pesquisa de opinião (à época, recente) exposta por Apple (2006, p.129) que mostrou que $47 \%$ dos estadunidenses acreditam que "Deus criou o homem da mesma forma como ele é hoje e em algum momento nos últimos 10,000 anos", tem-se um quadro desesperador do ponto de vista crítico do ensino de ciências. Até mesmo o argumento cético de que "quando a vida surgiu ninguém estava lá para testemunhar" (Spring 2010, p.115) já foi utilizado em prol da retirada da teoria da evolução de avaliadores locais e currículos. É inegável, com efeito, o forte apelo criacionista em neoconservadores republicanos, e, por conseguinte, em políticas educacionais e curriculares estadunidenses (ver Spring 2010; Apple 2006). No contexto brasileiro, o fenômeno similar vem se construindo nos últimos anos, se acentuado na cela do crescimento do movimento EsP (Selles 2016) e, derradeiramente, com a eleição em massa de candidatos de direita e extrema-direita em 2018. Apple (2006, p.127) resume o efeito dos pontos acima trazendo relatos de professores de biologia estadunidenses que evitam ensinar questões mais 'controversas' envolvendo teoria de evolução para não terem problemas com diretores ou burocráticos - ou, que propositalmente excluem a evolução pelo subterfúgio da 'falta de tempo'. A força do criacionismo (e da rejeição à teoria da evolução sem hipóteses ou narrativas religiosas) tendeu a aumentar no contexto brasileiro, especialmente com o fortalecimento também do movimento EsP - e, progressivamente, vê-se demandas de grupos que Apple (ibid) chama de autoritários-populistas-religiosos sobre ensino religioso e criacionismo nas escolas. Embora, no momento, maiores temores estejam sobre o ensino de ciências humanas - em razão das ameaças de acusação de 'doutrinamento ideológico' -, no caso do ensino de ciências da natureza a questão, em pontos específicos, não é menos grave. Teoria da evolução, cosmologia e idade do universo, modelos de tectonismo, geofísica e idade da Terra - estes e outros pontos, eventualmente tratados em aulas de ciências no ensino básico, são em grande medida ortogonais a crenças e mitos religiosos cristãos (e também outras). Não é de todo absurdo se supor que possam surgir, nos próximos anos, acusações de 'doutrinamento antirreligioso' por professores de ciências, os quais, em absoluto, estarão apenas tentando cumprir seus papeis - o de fornecer uma possibilidade de visão de mundo científica crítica sobre os fenômenos naturais.
\end{abstract}


como a de Terra plana são, em certo sentido, ambas 'erradas' - porém, a segunda é mais errada do que a primeira. Considerando a Terra como uma esfera perfeita, sua curvatura é aproximadamente 12 centímetros por quilômetro - extremamente próximo, numericamente, da curvatura da Terra plana, identicamente nula. Essa pequena diferença entre as curvaturas é o que ocasionaria nossa dificuldade em 'visualizar' o perfil ‘esférico’ da Terra, e explicaria parcialmente a aceitação de longa data do terraplanismo (Asimov 1989, p.39). Contudo, é ‘errado’ afirmar que a Terra é esférica, uma vez que há um modelo mais acurado, o da Terra enquanto esferoide oblato - cuja curvatura varia entre aproximadamente 11.97 e 12.03 centímetros por quilômetro (idem). Segue, porém, que mesmo este modelo também está ‘errado’ - modelos geoidais contemporâneos preveem desvios de milionésimos de centímetro por quilômetro na curvatura terrestre em comparação ao modelo elipsoide oblato. Todavia, novamente, mesmo estes, eventualmente, se mostrarão também 'errados’ (via indução pessimista). A questão, no entanto, é que este raciocínio não precisa levar necessariamente ao relativismo, aponta Asimov (idem), contanto que se perceba que a ideia de 'Terra plana' é mais ‘errada' que a de 'Terra esférica', e esta mais 'errada' que a 'Terra esferoide oblato', e assim por diante $^{66}$. Atenção insuficiente a este ponto leva ou a uma desvalorização ideológica da ciência - que pouco tem a contribuir para o EC com debates “anacrônicos e esdrúxulos” como o terraplanismo contemporâneo (Lang 2017) - ou, pelo contrário, à sua valorização ideológica - a visão positivista-cientificista, igualmente desinteressante ao EC e intensamente criticada há anos na área de pesquisa.

Um problema específico e atual do relativismo epistêmico no EC, caro a este trabalho e fundamental para este capítulo, é de que a VCNdC pode fatalmente levar, por diferentes caminhos, a uma visão relativista de conhecimento por professores e estudantes (RomeroMaltrana et al 2017; Martins 2015; Hodson 2014). Martins (ibid) sublinha que uma das principais questões problemáticas das listas de tenets da visão consensual - além da forma 'declarativa’ dos pontos das listas, que já traz em si diversos problemas - é a afirmação categórica de que 'a ciência tem um elemento subjetivo’. Como comenta o autor, tal colocação pode levar a uma compreensão simplista de 'teoria' - de que elas são 'opiniões' ou 'visão pessoal', um ponto justamente combatido e frequentemente

\footnotetext{
${ }^{66}$ Ainda que por trás deste raciocínio exista uma concepção de progresso - ou, de que o conhecimento científico sobre o formato da Terra é uma construção científica "com uma trajetória de 25 séculos de realizações teóricas e experimentais, (...) incorporado na práxis de diversas tecnologias em nossa sociedade" (Lang 2017, p.13), que se aperfeiçoa -, ela não se identifica obrigatoriamente ao espantalho positivista-cientificista.
} 
salientado pelos autores da visão consensual (Lederman \& Lederman 2014) -, ignorando estudos recentes em HFC que apontam para a importância da intersubjetividade à ciência (Daston \& Galison 2007; Daston 2017). Como Hodson (2014, p.922) aponta, este ponto de Lederman pode incidentalmente levar à compressão pelos estudantes de que toda a ciência e tudo nela é provisório - sendo que, postula o autor, caso os cientistas assim compreendessem provavelmente não existiriam progressos científicos de nenhuma natureza.

Nos sentidos apontados acima, Martins (2015, p.714) bem questiona:

(...) [A] VC [NdC] opõe-se a uma visão positivista, realista ingênua e de senso comum da ciência (...). Desconstruir essa visão tem sido parte da meta de um ensino sobre as ciências. Em seu lugar, a VC propõe uma visão que, embora não seja coesa e monolítica, parece situar-se no âmbito de um relativismo moderado ao apontar, p. ex., o aspecto provisório do conhecimento, a inexistência de um método único e rígido, a existência de vieses teóricos na observação e experimentação, as influências históricas, sociais e culturais da prática científica. Mas em que medida $a$ apresentação de uma visão relativista moderada não resultará na adoção de um relativismo exacerbado? (grifos do autor).

Isto é, a preocupação de Martins - e que é também a nossa neste trabalho - é de que os tenets da visão consensual, tanto devido a sua forma de apresentação como por seus conteúdos, possam ser mal interpretados - o que pode levar, por exemplo, a valorizações ou desvalorizações ideológicas da ciência, o que por sua vez vai certamente impactar na compreensão dos conhecimentos científicos específicos. Ou, ainda, eles podem levar a induções pessimistas como aquela criticada por Asimov (1989). O relato da experiência pessoal de Clough (apud ibid., p.716), quando do ensino por meio de 'princípios de NdC', é oportuno para ilustrar estes pontos:

(...) [Q]uando discutia o caráter histórico provisório da ciência, há alguns anos, ao ensinar ciências na escola secundária, meus estudantes saltavam do extremo de ver a ciência como conhecimento absolutamente verdadeiro para o outro extremo, como conhecimento não confiável. Era necessário muito esforço para movê-los para uma posição mais intermediária. Colegas contaram-me sobre estudantes que perguntavam por que eles tinham que aprender o conteúdo científico se ele estava sempre mudando. 
Apesar do relato acima ser pessoal e individual, não é exagero afirmar que se trata de um fenômeno comum mundo afora, e, portanto, não exclusivo da escola ou país a que se refere Clough (idem). Ademais, a facilidade dos acima mencionados estudantes em 'saltarem' de um extremo a outro, de uma valorização a uma desvalorização extremas da ciência, pode ser mais bem compreendida com base na hipótese esboçada no capítulo anterior - de que a grande presença de visões inadequadas sobre a ciência entre estudantes (e também professores) tem (parcialmente) razões ideológicas, reforçadas quase diretamente em meios de comunicação de massa (Cardoso et al 2015), por lógicas de popularização da ciência (Gavroglu 2012), em políticas educacionais de testes (Au 2013), currículos de ciências (Apple 2004), assim como em livros textos e outros meios de discurso educacionais (Désaultels 2015), e indiretamente pelos processos de mercantilização da educação e ciência. O esforço mencionado na citação acima acerca de trazer os estudantes a uma 'posição intermediária' reflete um dos maiores desafios das professoras e professores de ciências hoje em dia - e também uma das maiores fontes de estresse, cansaço físico e mental destes profissionais, raramente propriamente valorizados em suas carreiras e na sociedade.

O argumento central de Romero-Maltrana e colaboradores (2017) é que leituras superficiais sobre os tenets da VCNdC - algo que, colocam, é infelizmente mais comum do que se imagina - e insuficientes esclarecimentos de cada elemento nas listas podem levar fatalmente ao relativismo epistêmico no EC (ibid., p.3). Por um lado, os autores argumentam que ideais e conflitos de autores contemporâneos como Putnam, van Fraassen, Laudan e Psillos não são contemplados no conteúdo das listas. Por outro, defendem que as características sublinhadas nestas são na verdade elementos praticamente comuns em qualquer atividade humana, e, portanto, pouco tem verdadeiramente a dizer sobre a ciência e distingui-la de outras formas de conhecimento (ibid., p.20). O caráter epistêmico e objetivo da ciência, segundo os autores, são propriedades centrais da ciência que, trabalhados no EC, ajudariam a afastar o relativismo epistêmico. Para eles, a visão filosófica que melhor exprime uma visão crítica do caráter epistêmico e objetivo da ciência - equilibrada entre realismo e antirrealismo científicos é o realismo estrutural de Worral (1989). Numa sugestão implícita que tal visão deve fazer parte do EC, Romero-Maltrana e colaborares afirmam categoricamente que a NdC “deve ser a melhor arma contra o relativismo epistêmico” (ibid., p.21).

À guisa de conclusão desta seção, releva sublinhar que neste capítulo por desvalorização da ciência referimo-nos especificamente à faceta ideológica de tal 
fenômeno ${ }^{67}$. Como exercício inicial de análise, podemos distinguir dois níveis de desvalorização da ciência: nível individual e nível institucional-curricular. Um indivíduo se relacionar com práticas e conhecimentos tidos atualmente como não-científicos (como horóscopo, misticismo quântico, teses religiosas, entre outros) não se caracteriza automaticamente como uma desvalorização da ciência ${ }^{68}$. Por outro lado, o fenômeno deste indivíduo eventualmente fundar sua desconfiança na ciência em terreno ideológico (por exemplo, no relativismo epistêmico) é o que chamamos de desvalorização individual da ciência ${ }^{69}$. Analogamente, a nível institucional-curricular, não se caracteriza necessariamente como desvalorização da ciência o fato de políticas educacionais atenderem conhecimentos locais ou multiculturais (seja explicitamente nos currículos ou em metodologias de ensino). Todavia, o fato de políticas educacionais justificarem a ausência de conhecimentos científicos nos currículos em terreno ideológico (por exemplo, novamente, no relativismo epistêmico) é o que chamamos de desvalorização institucional-curricular da ciência ${ }^{70}$. Nosso ponto ao utilizar tais conceitos, portanto, é que o relativismo epistêmico - característico de correntes pós-modernistas e em discursos curriculares - contribui para uma desvalorização (ideológica) da ciência, especialmente a nível institucional-curricular.

\footnotetext{
${ }^{67}$ Isto é, queremos dizer com isto que o fenômeno de desvalorização individual acerca de algo é amplo, complexo, contendo portanto várias facetas. Não intencionamos, assim, reduzir este fenômeno a uma questão tão somente ideológica - por outro lado, insistimos que esta sua faceta é especialmente importante para entendermos, pelo menos inicialmente, o fenômeno de desvalorização da ciência.

${ }^{68}$ Corroborando parcialmente este ponto, é oportuno citar as pesquisas de percepção pública da ciência e tecnologia no Brasil feitas pelo Centro de Gestão e Estudos Estratégicos (CGEE) em 2015, concluiu-se que cerca de $80 \%$ dos entrevistados discordaram quanto à afirmação 'O horóscopo prevê o futuro' (CGEE 2017, p.78). Curiosamente, por meio de modelos de regressão logística, tem-se que a pequena parcela que afirmou concordar com a frase acima tende tendeu a concordar (na porcentagem de 60\%) com as afirmações 'A ciência e a tecnologia vão ajudar a eliminar a pobreza e a fome do mundo' e ' $O$ desenvolvimento científico e tecnológico levará a uma diminuição das desigualdades sociais no País’. Entre aqueles $80 \%$ que discordaram da afirmação acerca das previsões dos horóscopos, cerca de $45 \%$ tendeu a concordar com as mesmas duas afirmações.

${ }^{69}$ Por meio de uma construção análoga, podemos distinguir também o que entendemos por valorização individual da ciência. Com efeito, um indivíduo se relacionar com práticas e conhecimentos tidos atualmente como científicos não se caracteriza automaticamente como uma valorização da ciência. Contudo, o fenômeno deste indivíduo eventualmente fundar sua confiança na ciência em terreno ideológico (por exemplo, no positivismo-cientificismo) é o que chamamos de valorização individual da ciência. Notase que assim estamos, portanto, diferenciando valorização e desvalorização ideológica da ciência e crítica da ciência (ver Galison 2008).

${ }^{70}$ Como fizemos em nota anterior, também podemos identificar o que seria uma valorização institucional-curricular da ciência, quando da justificação ideológica (cientificista-positivista) de políticas educacionais sobre presença de conhecimentos científicos nos currículos e metodologias de ensino. Considerações semelhantes podem ser feitas acerca da valorização (ideológica) institucional de avaliações de larga escala, quando fundadas em ideologias cientificistas-positivistas, conforme foi discutido em capítulo anterior (ver Au 2013).
} 
Nas próximas seções exploraremos outras características do relativismo, o qual, ao lado da mercantilização da educação, entendemos como outro grande problema atual da educação, que precisa ser urgentemente tratado e discutido. Discutiremos como o localismo curricular - ou, a tendência de se enfatizar conhecimentos locais em currículo e ignorar ou desprezar conhecimentos científicos - é uma consequência da influência do relativismo epistêmico pós-moderno em educação. Discutiremos, amparados na teoria de Young e outros realistas sociais, que o acesso aos conhecimentos poderosos é, nesse contexto, um instrumento de justiça social, uma forma de combater mecanismos sociais que estratificam as classes e as formas de educação, reforçando e acentuaNdo as desigualdades sociais.. Proporemos uma transposição do conceito de Young de 'conhecimento poderoso' ao nível meta, e argumentaremos que existem metaconhecimentos poderosos que tem extrema relevância epistêmica e política no EC. Para isso, proporemos uma articulação do realismo social com o realismo estrutural epistêmico, inaugurado por Worral (1989). Apresentaremos, enfim, um argumento curricular mostrando um papel político da FC no EC - que há anos já é defendida, mas por outros caminhos.

\subsection{Relativismo epistêmico pós-moderno e a desvalorização ideológica da ciência}

A controvérsia do relativismo nas ciências e no EC é não raro associada ao famigerado episódio da 'guerra das ciências'. Dentre as inúmeras investidas nesta - eclodida com a revelação do artigo embuste de Alan Sokal ${ }^{71}$-, certamente aquela referente à 'equação sexista de Einstein' foi uma das mais populares. Esta ficou conhecida pela citação (descontextualizada) de Sokal e Bricmont (1998) em Impostures Intellectuelles sobre a afirmação da filósofa feminista belga Luce Irigaray de que " $E=m c^{2}$ é uma equação sexista (...),72. Os autores alegam ser este um exemplo do nonsense típico de autores associados ao pós-modernismo. Outro conhecido exemplo citado pelos autores é a

\footnotetext{
${ }^{71}$ Referimo-nos, naturalmente, ao artigo de título 'Transgressing the Boundaries: Towards a Transformative Hermeneutics of Quantum Gravity’, publicado em 1996 no periódico Social Text depois de episódios controversos envolvendo a edição e revisão de seu conteúdo.

${ }^{72}$ Importa mencionar que a referência bibliográfica ao trabalho de Irigaray por Sokal e Bricmont, nas versões francesa, estadunidense e brasileira, está errada. A curiosa menção da autora é encontrada na transcrição de uma sessão de perguntas em uma conferência ocorrida em 1985, em Irigaray (1987).
} 
suposta consideração de autores associados ao pós-modernismo sobre a escolha dos matemáticos do símbolo i (número imaginário) - devido ao formato 'fálico'- para representar a 'penetração’ na natureza e sua conquista pela ciência, legitimando o estupro e a opressão (Hicks 2004, p.19). A 'guerra' tomou contornos tais que 'defensores da ciência’, nos termos de Shapin (2012, p.14), argumentaram que os 'anticientíficos’ rótulo dedicado a historiadores e sociólogos da ciência que têm 'pouca fé' na ciência deveriam ser coerentes consigo mesmos, e "consultar curandeiros em vez de neurologistas quando tivessem dor de cabeça" ${ }^{\text {"73 }}$. Anos depois, seus ecos ainda ressoam, e a manutenção mais ou menos geral do desconforto entre 'científicos' e 'não-científicos' sugere que nada mais serviu do que aumentar ainda mais a distância entre estes (ver Ávila 2013).

Muito antes deste famigerado episódio, uma das primeiras menções ao termo 'pósmodernismo ${ }^{74}$ se deu na publicação da obra do filósofo francês Jean-François Lyotard $L a$ condition postmoderne em 1979, entendida como um dos marcos da virada pós-moderna na segunda metade do século passado. Contudo, o universo do pós-modernismo estendese além e muito antes da obra de Lyotard - e, também, é muito mais importante que os exageros de ambos os lados na infeliz 'guerra das ciências' podem sugerir. Com efeito, tomando o pós-modernismo como fenômeno cultural (Jameson 1996), podemos entender com Bernstein (2000b, p.72) que o capitalismo tardio trouxe novas formas de pressão cultural sobre novas gerações e identidades ‘tradicionais’ (como aquelas de gênero) que, como resultado, facilitaram a construção de novas identidades. Tais novas identidades e minorias ${ }^{75}$ estão no seio da defesa política pós-moderna pelas causas locais e refratárias (Abbeele 2011, p.12), prezando pelo dissenso, pluralismo, diferenças culturais e

\footnotetext{
${ }^{73}$ Não cabe prolongarmo-nos sobre os desdobramentos desta 'guerra' - muitos deles infelizes, por terem levado mais a confusões do que compreensões -, o que já foi (e continua sendo) bastante trabalhado na literatura especializada (ver Ávila 2013).

${ }^{74}$ As possíveis distinções dos termos 'pós-modernismo' e 'pós-modernidade' são importantes e precisam ser minimamente comentadas. Tomaremos a concepção de Abbeele (2011, p.15), para quem pósmodernidade se refere à situação sócio-histórica na qual se saturou o discurso da modernidade associada ao Iluminismo. Em outras palavras, pós-modernidade seria a 'mudança de paradigma' - nas palavras do autordas fábricas e locomotivas aos chips de silício e comunicação digital - ou, uma passagem para a era pósindustrial pós-fordista (Usher \& Edwards 1994, p.8). Assim, pós-modernismo pode ser entendido como a reação artística-cultural-filosófica (caberiam outros adjetivos) a este ambiente. É oportuno citar Fredric Jameson (apud Grant 2011, p.31), que identifica pós-modernismo como a lógica cultural do capitalismo tardio, de tal forma, por exemplo, que a incredulidade e pessimismo característicos teriam raízes econômicas. Naturalmente, estas não são as únicas formas de conceber a distinção entre aqueles termos. Como último exemplo, Foucault (apud Usher \& Edwards 1994, p.9) vê 'modernidade' e 'pós-modernidade' como forças opostas que estariam presentes em qualquer época ou período.

${ }^{75}$ Uma questão delicada, apontada por Abbeele (2011, p.12), é que as minorias neste caso podem conter também, ao lado de minorias historicamente oprimidas estruturalmente, grupos tais como neofascistas e ultranacionalistas.
} 
ceticismo à autoridade coletiva ${ }^{76}$ (Sim 2011a, p.xiii). A título de exemplo, algumas correntes do multiculturalismo e feminismo ${ }^{77}$ tiveram influência pós-moderna em especial nas últimas décadas. Reconhece-se a importância dos primeiros por agregar apelos políticos e morais de uma grande gama de grupos minoritários e marginalizados o que inclui, mais recentemente, o foco sobre imigrantes (minorias étnicas e religiosas), minorias nacionais e indígenas (Song 2017). A influência pós-moderna sobre o feminismo ficou mais clara na chamada 'terceira onda' - denominada por alguns autores de pós-feminismo (de Lucena 2012, p.7) -, que se mostrou crítica a formas anteriores de feminismo, integrando debates sobre 'raça', etnia, sexualidade e lócus social, e argumentando pelo ‘essencialismo aparente’ dos gêneros (Butler apud Boucher 2015, p.332).

Contudo, de forma a concentrarmo-nos sobre o relativismo epistêmico pós-moderno, a obra mencionada de Lyotard é especialmente oportuna. Resumidamente, nela destaca-se o uso do conceito de jogos de linguagem de Wittgenstein, a associação desta com a ideia de performance, e a crítica do que chama 'grandes narrativas', ou 'metanarrativas' - isto é, grandes teorias que se propõem a explicar tudo, resistentes a mudanças (Sim 2011b, p.7). Lyotard argumenta que o conhecimento se tornou nos tempos atuais a mais significativa comódite, sendo instrumento de poder e fonte de conflito entre nações (ibid., p.8). Entendendo ciência como uma grande narrativa, Lyotard critica sua ligação intrínseca à administração e acumulação de capital, acusa as narrativas que a legitimam - a tradição iluminista - e também seu poder de exclusão a outras formas de conhecimento (Aylesworth 2015, p.11). Em ressonância ao seu tempo - em especial aos ecos de maio de 68 - Lyotard define a condição pós-moderna como a incredulidade frente a grandes narrativas (apud idem).

O marxismo, como grande narrativa, não fugiu às críticas do filósofo - o que em parte é reflexo de sua frustração, semelhante à de outros intelectuais franceses, com ápice na postura reacionária do Partido Comunista francês nos eventos de 68, levando-o a se afastar do 'marxismo oficial' (Sim 2011b, p.7). O que se compreende como falhas neste é sua incapacidade de mudar com o tempo, de acompanhar as mudanças da sociedade, de insistir-se como única verdade, e na imposição sobre outras teorias - o que o torna, nesse

\footnotetext{
${ }^{76}$ Dando lugar, no entanto, às autoridades identitárias segundo Sim (2011a, p.xiii).

77 Ambos estes termos, assim como 'pós-modernismo', são genéricos no sentido de servirem de referência a abordagens teóricas que eventualmente podem ser opostas em alguns pontos. Por outro lado, o uso de ambos os termos no singular não pode fazer esquecer que, a rigor, não existe unidade de pensamento ou prática política homogênea em nenhum dos dois (de Lucena 2012).
} 
sentido, uma grande narrativa autoritária (ibid., p.10). Em oposição então ao autoritarismo das grandes narrativas, Lyotard apela pelas 'pequenas narrativas' - reinterpretadas constantemente, sujeitas e receptivas a mudanças. Estas se manifestariam na luta de pequenos grupos - não em um grande grupo, ou classe - com objetivos estreitos em comum - não um objetivo amplo -, sem pretensão de responder a todos os problemas da sociedade, tão logo se dissolvendo ao passo que tais objetivos são alcançados (ibid., p.8).

Diferentes autores traçam raízes filosóficas do pós-modernismo mais ou menos condizentes, por vezes tomando autores ou correntes filosóficas conflitantes entre si. São atribuídos como precursores ao pós-modernismo $\mathrm{Kant}^{78}$, por exemplo, (Abbeele 2011, p.18), Hegel (Hicks 2004), Kierkegaard, Marx, Freud e, principalmente, Nietzsche (Aylesworth 2015, p.4). No século XX, algumas das principais referências e nomes ligados ao pós-modernismo à época de La Condition Postmoderne incluíam Wittgenstein (segundo), Heidegger, Lacan, Foucault, Baudrillard, Deleuze, Guattari e Derrida - ainda que estes últimos sequer utilizassem o termo 'pós-modernismo', tampouco intitulavam-se 'pós-modernos' (ibid., p.23). O impacto e influência destes autores na filosofia ocidental é inegável, e reflete-se nos tempos atuais na grande diversidade de 'teorias pós' - tais como pós-estruturalismo, pós-fundacionismo, pós-empirismo, pós-marxismo, póscolonialismo, entre outros.

Em razão de tal diversidade, não raro caracterizações do pós-modernismo são parciais e localizadas. De fato, Usher e Edwards (1994, p.7) afirmam que é até mesmo impossível definir pós-modernismo, uma vez que tal tentativa significa totalizá-lo ou atribuir-lhe uma ontologia e identidade únicas e atemporais - nesse sentido, afirmam que seria impossível também alguém se intitular 'pós-moderno' (ibid., p.3). Todavia, a tentativa de síntese de Lopes (2013, p.8) é oportuna, tanto por seu exercício de riqueza textual como pelo tom confessadamente pós-moderno em seu diagnóstico das características dos tempos em que vivemos:

(...) um tempo de fim das utopias e das certezas, de desmoronamento da ideia de verdade centrada na prova empírica, na objetividade, na natureza ou na evidência matemática. Um tempo de explosão das demandas particulares e das

\footnotetext{
${ }^{78}$ Esta atribuição é feita por Lyotard. Embora Kant não raro seja considerado o maior racionalista iluminista (Dutra 2010, p.121), sua filosofia crítica abriu espaço para certa dose de idealismo - a qual o filósofo procurou distinguir dos idealismos de Descartes e Berkeley (ibid., p.137)-, sem, contudo, necessariamente abandonar o realismo metafísico sobre as coisas-em-si. Kant é por vezes considerado o primeiro construtivista filosófico, em razão de seu postura idealista quanto ao papel ativo das estruturais mentais a priori na construção do conhecimento, segundo Staver (2012, p.1019).
} 
lutas da diferença, de aceleração das trocas culturais e dos fluxos globais, de compressão espaço-temporal. Estamos aqui e ao mesmo tempo estamos noutro lugar e outros lugares e tempos estão em nós, fazendo com que relativizemos a ideia de passado e a de futuro, já que narramos a nossa vida tendo em vista um passado que inventamos e um futuro que projetamos, passado e futuro que não são os mesmos nos diferentes lugares. Antigos projetos de uma sociedade sem poder, sem classes, sem conflitos, reconciliada consigo mesma, são abandonados e novos projetos utópicos não parecem ser construídos como substitutos. Mesmo porque a concepção de um ser humano centrado, consciente dos seus direitos e capaz de reivindicar e lutar por esses projetos, é desconstruída. (...) Nem a ciência, nem Deus, nem um partido, nem a dialética, nem a formalidade matemática, nem as regras administrativas servem mais - se é que um dia serviram - de porto seguro para nos constituir como sujeitos, balizar os nossos projetos e para a resolução dos conflitos em torno de diferentes opções de leitura do mundo.

A condensação de ideias acima reflete o acúmulo de estudos e análises de e sobre diferentes autores que compõem o que a autora em seu contexto entende por pósmodernismo. Deve-se a Foucault - e, de certa forma, também Nietzsche - a noção de sujeito descentrado, desintegrado e ‘descontínuo’ na história, conforme se interpreta das pesquisas genealógicas (Aylesworth 2015, p.16). O termo 'desconstrução' ganhou destaque pela obra de Derrida (ibid., p.23) - seus trabalhos sobre a instabilidade e indeterminabilidade da linguagem, seu conceito de ‘différance’ e ênfase pela 'différence’ foram muito influentes (Sim 2011b, p.4). O pessimismo quanto a utopias é o outro lado da moeda da incredulidade a grandes narrativas, a condição pós-moderna segundo Lyotard (Abbeele 2011, p.19). O abandono de projetos de sociedade exprime em grande medida o já mencionado abandono do projeto marxista como grande narrativa - mais especificamente seu teleologismo e sua defesa da resolução de todas as iniquidades sociais pela revolução (ibid., p.20).

O abandono da razão - e, consequentemente, da ciência -, caro a muitos autores associados ao pós-modernismo, tem raízes especialmente em Nietzsche e Heidegger por sua rejeição à razão iluminista (Hicks 2004). O desmoronamento das certezas, verdade e objetividade e o relativismo sobre espaço e tempo pautam-se fortemente na tese da indistinguibilidade do real e do aparente (Aylesworth 2015, p.7). O abandono da 'realidade’ é uma consequência, a título de exemplo, do niilismo epistemológico de Baudrillard, que argumenta que a rede sem fim de signos que não vetorizam referentes 
reflete uma sociedade saturada pela mídia e imersa naquilo que chama 'hiperrealidade' (Abbeele 2011, p.21). O real, metaforiza Baudrillard, foi vítima de um crime perfeito, e não se pode confirmar sua morte uma vez que o corpo desapareceu (Grant 2011, p.103). Lyotard, transmitindo a ideia do descrédito à grande narrativa da razão científica progressista, afirma que a ciência está ‘fora de moda’ (Ayleworth 2015, p.13).

Filosoficamente, não acidentalmente o pós-modernismo é por vezes associado a tipos de antirrealismos - como resultado da crítica ao realismo ou como rejeição deste (Usher \& Edwards 1994, p.14) - ou, ainda, como algo além mesmo do antirrealismo ao questionar uma realidade independente de representações (idem). Ao se defender que a realidade é construída sociolingusticamente ${ }^{79}$, alguns autores pós-modernistas tomam a subjetividade individual como princípio (Hicks 2004, p.6), o que beira o solipsismo segundo muitos de seus críticos ${ }^{80}$. Na síntese particular de Usher e Edwards (1994, p.10):

\begin{abstract}
A postura epistemológica que vê o método científico como um conhecimento neutro e, portanto, 'verdadeiro', não é tão prontamente aceita. Há um reconhecimento cada vez maior de que todas as reivindicações do conhecimento são parciais, locais e específicas, em vez de universais e ahistóricas, e que estão sempre impregnadas de poder e interesses normativos de fato, o que caracteriza a modernidade é precisamente o esconder da parcialidade e o enraizamento contextual do conhecimento no manto de universalidade e neutralidade. Assim, na pós-modernidade, há uma rejeição dos fundamentos universais e transcendentais do conhecimento e do pensamento, e uma maior conscientização sobre o significado da linguagem, do discurso e da localização sociocultural na criação de qualquer reivindicação de conhecimento.
\end{abstract}

Visando caracterizar as teorias pós-críticas de currículo - como um apanhando deliberadamente vago e impreciso de teorias pós-modernas (Lopes 2013, p.10) -, Lopes afirma que uma das marcas centrais de ‘teorias pós’ é o abandono do essencialismo - em especial ao essencialismo na significação. O conceito de jogos de linguagem de Wittgenstein é evocado no argumento de que os sentidos dos enunciados (significados) dependem dos contextos e de suas regras (idem). O universalismo e estruturalismo,

\footnotetext{
${ }^{79}$ Neste sentido, muitos autores relativistas abusam da chamada hipótese de Sapir-Whorf (Staver 2012, p.1023). Em colocações simples, a hipótese carrega a ideia de que linguagens moldam a cultura e determinam pensamentos. Assim, o 'mundo real' nada mais é do que a construção inconsciente feita a partir da linguagem - duas linguagens diferentes levam a dois 'mundos reais', distintos (Sapir apud idem).

${ }^{80}$ A corrente conhecida como Construtivismo Radical (von Glasersfeld 1995), como será discutida em seção posterior, é um exemplo de tal tipo de postura em educação, ainda que minoritária (e duramente criticada ao longo dos últimos anos) (ver Matthews 1997).
} 
legados do Iluminismo como afirma a autora, são substituídas pela contingência - o discurso, ao invés de estruturalmente definido, é indefinido e constantemente reestruturado (ibid., p.13). Como afirmam Usher e Edwards (1994, p.10), para o pósmodernismo, a falta de certezas, a flutuação de sentidos, a miríade de significados (ao invés da profundidade destes), tudo isso compõe a 'norma', que deve ser celebrada - e não lamentada, como fazem os 'nostálgicos de modernismo', nas palavras de Lopes (2013, p.9).

De fato, o pós-modernismo é entendido não só como uma análise crítica da pósmodernidade, mas também como uma rejeição ao modernismo. De início, poder-se-ia entender o pós-modernismo como uma superação deste último (como, pois, sugere o prefixo), todavia, existe resistência a esta forma de raciocínio - justamente por reduzir-se à utopia modernista do gradualismo histórico (Lopes 2013, p.10). A rejeição ao modernismo se dá, principalmente, por ter sido base à civilização ocidental, associada à colonização, acumulação de capital (Abbeele 2011, p.19), dominação, destruição e opressão (Hicks 2004, p.3), orquestradas pelo capitalismo industrial e democracia liberal. A ideia de eliminação dos males sociais pelo progresso - fruto da racionalidade iluminista e central à ideologia positivista-cientificista, como já discutido anteriormente - é reprovada à luz da persistência destes males e do aumento dos custos sociais, ecológicos e materiais do desenvolvimento tecnológico (Usher \& Edwards 1994, p.10). Por estes motivos, o Holocausto segundo Lyotard (apud idem), as bombas atômicas e 'genocídios de toda espécie' segundo Lopes (2013, p.15), representariam o triunfo de tal racionalidade e da aplicação da ciência à barbárie, marcando a falência das facetas humanista e progressista do modernismo. Nesta mesma direção, a gradual derrocada da influência soviética em países do leste europeu (Sim 2011b, p.8), o fim da própria União Soviética e a queda do muro de Berlim, representariam o descrédito contemporâneo com a grande narrativa marxista (Lopes 2013, p.19), assim como o triunfo da lógica mercadológica desde a economia até a vida e cultura íntimas (Abbeele 2011, p.19).

O modernismo também é culpado por privilegiar pequenos grupos poderosos à custa da exploração de minorias étnicas, desfavorecidos e mulheres - o que evidenciaria sua natureza opressora em oposição à 'propaganda emancipadora' (Usher \& Edwards 1994, p.31). Essa opressão implicaria num ataque às diversidades pela proposição de 'assimilação' das minorias à dominância - isto é, os poderosos, no vocabulário adotado pela NSE. Esse é um dos campos de estudo de teorias pós-coloniais, a qual, entre outros importantes papeis, questiona "a ideia de que a cultura dos países colonizados é apenas 
um efeito da opressão colonizadora” (Lopes 2013, p.14). Igualmente, as ideias de superioridade cultural do 'centro' sobre a 'periferia', do 'ocidente' sobre o 'oriente', da 'alta cultura’ sobre a 'cultura popular', são questionadas (ibid. p.15). Levadas à educação, estas questões podem traduzir-se no embate entre 'conhecimentos não-dominantes’ (ou locais, ou multiculturais) e os 'conhecimentos dominantes' (comumente associados às disciplinas escolares usuais).

Não causa surpresa notar que 'modernos' reagiram contra os ataques pós-modernos sendo o episódio da 'guerra das ciências' um dos mais infelizes exemplos. Porém, há também uma reação pré-moderna ao pós-modernismo. Sim (2011a) cita como o fundamentalismo religioso tem se fortalecido enquanto grande narrativa em alguns contextos após os incidentes de 11 de setembro de 2001, se opondo ao relativismo moral pós-modernista (ibid., p.x). Os fundamentalismos islâmicos, que fomentaram nos últimos anos a criação de teocracias pautadas na autoridade institucional-religiosa - $\mathrm{e}$ organizações paralelas, como o Estado Islâmico-, representam segundo o autor uma reação não só ao pós-modernismo como também ao modernismo (idem). No mesmo sentido, o crescimento de cristianismos radicais, para Sim (ibid. p.xi), também enfraquece a tese pós-modernista sobre o descrédito de grandes narrativas. $\mathrm{O}$ autor comenta $\mathrm{o}$ exemplo estadunidense com a crescente influência de grupos conservadores cristãos sobre o Partido Republicano, que agem no sentido em diferentes frentes - como os movimentos 'pró-vida' contra aborto e liberdade sexual e de gênero -, combatendo o 'ameaça multicultural' (Buras \& Apple 2008, p.20) e o relativismo cultural (Sim 2011a, p.xi). Aspectos semelhantes podem ser notados no contexto brasileiro no atual levante conservador, em especial com o movimento ESP e a forte influência de setores religiosos na política (Ação Educativa 2016).

Do ponto de vista filosófico, uma das críticas mais conhecidas ao relativismo epistêmico pós-modernista provém de argumentos que envolvem de alguma forma contradição por autorreferência. Numa postura de procurar entender o pós-modernismo antes de descarta-lo como nonsense, Habermas, em Der Philosophische Diskurs der Moderne, argumentou que Nietzsche, Heidegger, Derrida e Foucault acabam por serem contraditórios em suas críticas ao modernismo ao usarem conceitos e métodos que só a ‘razão moderna’ pode providenciar (Aylesworth 2011, p.33). Ainda, argumenta que aqueles que transpõem a crítica radical à razão ao domínio da retórica, com o fim de fugir do argumento da autorreferência, também acabam por se utilizar da razão moderna (ibid., p.35). Ao cabo, Habermas vê o pós-modernismo como ideologicamente suspeito (Sim 
2011b, p.12), defendendo a crítica da razão moderna e não seu 'abandono’. Rebatendo Lyotard - a quem Habermas chama de 'jovem conservador', tal qual os outros 'novos filósofos franceses’ (Grant 2011, p.29)-, argumenta que os horrores do século XX não se devem à razão iluminista, mas sim exatamente à falta dela, ou, à não concretização do projeto modernista (Abbeele 2011, p.18).

Outro conjunto de críticas resume-se à rejeição do pós-modernismo por ser uma versão contemporânea de ceticismo filosófico - isto é, segundo Sim (2011b, p.12) um discurso pretensiosamente desestabilizador de outras teorias, sem ao mesmo compor-se enquanto uma. Usher e Edwars (1994, p.26) argumentam que não necessariamente o pósmodernismo recai ao ceticismo e relativismo, uma vez que especialmente este último é um 'conceito moderno'. Rorty (apud Hicks 2004, p.2), evitando cair no problema da autorreferência, argumentou que os discursos pós-modernistas sobre a verdade e a realidade não são frutos de um ceticismo, mas 'irônicos’ e 'retóricos'. Concordantemente, segundo Abbeele (2011, p.20) o discurso pós-moderno - pela inspiração nietzschiana direta - tende a ser mais estrategicamente dissimulado do que denunciatório, e mais irônico do que acusatório. Usher e Edwards (1994, p.15) afirmam ainda que a 'brincadeira' e a 'cômica' pós-modernas substituem a 'seriedade' moderna, a qual, segundo os autores, desmerecem outras culturas e formas de conhecimento como 'não sérias' - o 'lúdico’ serviria de constante subversão e transgressão ao poder dos discursos de grandes narrativas (ibid., p.16). Entretanto, Habermas já argumentara que muito dos artifícios retóricos de pós-modernos em fugir do problema da autorreferência são inócuos aos seus propósitos, e acabam recaindo novamente ao problema (Aylesworth 2011, p.34). De forma a complementar a crítica filosófica de Habermas, é oportuno citar muito brevemente também algumas críticas de dois importantes sociólogos Stuart Hall e Pierre Bourdieu sobre exageros do pós-modernismo.

Hall, naturalmente, reconhece a importância da 'ruptura pós-modernista' em especial aos estudos culturais, sem, contudo, poupar-lhe críticas. Uma primeira delas repousa justamente sobre uma faceta do discurso rupturista pós-moderno, intencionado a sublinhar uma cisão absoluta com o passado (modernismo) - ao qual Hall argumenta que um olhar sensato revela tanto rupturas como continuidades, e que tal intenção é de natureza ideológica (Grossberg 1986, p.47). O relativismo pós-moderno carrega, segundo o autor, uma compreensão simplória de teoria como um condensado de paradigmas fechados - e como não um empreendimento dinâmico e aberto. Embora concordando com o enfraquecimento das grandes narrativas - Hall, com efeito, se considera de certa 
forma um 'pós-marxista', maravilhado com o 'projeto modernista' (ibid., p. 51-8)-, argumenta que discursar o fim da 'era racionalista' em tempos de enormes mudanças tecnológicas e culturais é inócuo, e que tal discurso é erigido de uma concepção de cultura abstraída das suas condições materiais, técnicas e econômicas (ibid., p.51). Repetindo uma recorrente colocação contra o pós-modernismo, Hall afirma que as extrapolações pós-modernistas em geral são exageradas, "selvagemente ideológicas” e estúpidas (ibid., p.50). Teóricos pós-modernos, em sua visão, falham em perceber os seus próprios privilégios, uma vez que a grande maioria da população mundial sequer entrou na 'era moderna' - ou, como articulado por Hobsbawm, 80\% da humanidade saiu da Idade Média (na acepção eurocêntrica) apenas nos anos 1950 (Morley \& Chen 2000, p.14).

Em uma de suas última obras, Science de la Science et Reflexivité - resultado do seu último curso na Collège de France-, Bourdieu (2001, p.7) mostrou-se bastante crítico ao que chamou de alguns 'delírios pós-modernos' e sua ameaça à ciência ${ }^{81}$. Um ponto particularmente atacado pelo autor é algumas retóricas anticientíficas que desembocam em proposições radicais - as quais podem ser, em geral, indefensáveis ou mesmo absurdas. Nestas se enquadrariam autores semiologistas radicais que flertam com a tese de que "tudo é texto" (ibid., p.45), o que pode levar à condição contraditória de que a ciência seria 'apenas mais um discurso ficcional' com um enorme poder de 'efeito de verdade'. Neste sentido, acusa alguns ‘construtivistas radicais' - como seu compatriota Bruno Latour - de se esconderem sob a ambiguidade do termo 'construção’ ao tentarem se esclarecer. Por outro lado, Bourdieu também se mostra contrário à redução total da ciência a estratégias de influência, poder, prestígio, e a formação de alianças em prol do que chama 'crédito simbólico' (ibid., p.46). Ainda, mostra-se crítico a algumas apropriações das obras de Kuhn e Wittgenstein por sociólogos da ciência do chamado programa forte - sobre último, Bourdieu atenta ao fato que o próprio filósofo austríaco esclareceu que sua investigação não fazia respeito às ciências naturais (ibid., p.113). Interpretações descuidadas do rupturismo kuhniano podem levar a uma distinção a qualquer custo entre 'velho’ e ‘novo', 'paradigmas’ e 'não-paradigmas’, forçando artificialmente diferenças e impondo o ‘recomeço do zero’ após cada ruptura, impedindo

\footnotetext{
${ }^{81}$ Entendemos ser necessário enfatizar que nossa modesta apropriação de Bourdieu neste trabalho se resume ao seu último curso, e que nos esforçamos no sentido de não distorcer suas teses lá apresentadas, ou generalizá-las imprudentemente. Contudo, no intuito de tentar apreciá-las num contexto mais geral dialogando, por exemplo, com teóricos de currículo e outros autores da HFC -, entendemos que as considerações do autor expostas são satisfatoriamente autossuficientes e, em particular, muito importantes para serem ‘cultuadas' somente dentro do ‘círculo bourdesiano'.
} 
qualquer ideia de acumulação ou continuidade (ibid., p.20). O relativismo da verdade, pelo menos nas ciências sociais, manifesta-se segundo Bourdieu no que chama de “contaminação da ordem científica por princípios de ordem política e da democracia” (ibid., p.103), a qual resulta num desejo de 'pluralismo' quanto à verdade, que diferentes forças sociais (além das ciências, como políticos e religiosos) gozem do direito de "dizer a verdade sobre o mundo social” (idem).

As considerações de Bourdieu serão muito oportunas posteriormente quando da discussão da defesa de Young acerca da socialidade da objetividade científica. Na próxima seção, intentaremos apresentar de forma condensada algumas das influências do relativismo epistêmico pós-moderno na educação.

\subsection{Localismo epistêmico-curricular}

A influência do relativismo epistêmico nos currículos, em especial aquela devido a autores associados ao pós-modernismo, um dos impulsionadores da obra recente de Young, mostrou-se particularmente visível a partir do início da década de 1990 (ver Aronowitz \& Giroux 1991; Usher \& Edwards 1994; Doll Jr 1993; Pourois \& Desmet 1997). Usher e Edwards (1994, p.25) argumentam que, embora tal influência não tenha sido uniforme, ela se manifestava nos apelos emergentes à época por interdisciplinaridade, abordagens mais experienciais (práticas), entre outras - e ela só não seria mais forte devido à ‘natureza iluminista’ da educação em suas origens (ibid., p.24).

A origem moderna-iluminista da educação e do currículo é resumida - em um tom crítico - por Lopes (2013, p.9):

Sabíamos o que ensinar, ou mais modestamente sabíamos o que não ensinar, mesmo quando não conseguíamos condições objetivas para que esse ensino fosse garantido a todos e todas. Acreditávamos nos conteúdos básicos do currículo como saberes que poderiam garantir o projeto de sociedade com o qual sonhávamos. Esses conteúdos eram concebidos como o centro do currículo - seu core - e trabalhávamos pela formação de sujeitos - os cidadãos emancipados e críticos ou os intelectuais orgânicos gramscianos - capazes de atuar pelas mudanças sociais entendidas como de interesse da maioria da população de um país, ou mesmo da humanidade, e como garantidoras do projeto social pretendido. 
A frustração com o ideal iluminista e com projetos de sociedade revolucionários, traços do pós-modernismo para a autora (idem), levariam então à situação de não sabermos absolutamente o que ensinar e ao abandono do papel social do currículo guiado pelo conhecimento. Assemelhando-se à controversa e intensamente discutida afirmação freudiana, de que educar é um ofício impossível, Lopes e Macedo (2015) afirmam que, embora necessária, a formação docente também é impossível. É cada vez mais enfática a dúvida sobre os 'cânones do conhecimento', como afirma Bauman (2005) utilizando sua conhecida metáfora, na 'modernidade líquida'. Estes e outros fatores teriam aberto espaço para outras formas de conhecimento - em especial conhecimentos locais, defendidos pelo que Young (2016a) chama de 'discurso das vozes'. Estas pautadas sobre a antítese da contingencialidade da verdade e da racionalidade oposta à (suposta) tese da verdade e racionalidades únicas, universais e invariantes (Usher \& Edwards 1994, p.27). Embora alguns autores associados ao pós-modernismo neguem que sua postura coadune com um relativismo epistêmico (ibid., p.26), Young e outros autores associados simpatizantes ao RS na sociologia da educação veem nelas simplificação exagerada do construtivismo social e redução completa de conhecimento a relações de poder (Deng 2015). Tal reducionismo completo na teoria de currículo reflete o que Zavale (Maton apud Zavale 2017, p.484) cita como ‘cegueira do conhecimento’, isto é, a lógica de absolutos: “ou os currículos eram baseados em forças sociocontextuais, sem base para a sua objetividade, ou eram baseados no ideal positivista da universalidade do conhecimento, sem referência a contextos sociais”. A preferência de 'conhecimentos locais' sobre 'conhecimentos universais’ no currículo chamaremos de localismo curricular.

Autores simpáticos a posturas realistas (e, em especial, ao RS) vêm apontando nos últimos anos algumas consequências negativas de correntes educacionais que tendem ao localismo curricular. Uma delas, bastante direta segundo Young (2016b, p.7), é de que currículos focados exclusivamente em conhecimentos locais - ou orientados unicamente para contextos do cotidiano - pode ocasionar numa posterior dificuldade em estudantes em estender certos conceitos para fora dos contextos locais ou cotidianos. Tais consequências não afetam apenas o contexto em sala de aula e os processos de aprendizagem, mas os próprios estatutos epistemológicos do conhecimento. Em uma tentativa de categorizar e descrever outras consequências, Young (2011, 2016a) - numa influência popperiana - introduziu os conceitos de 'Futuro 1', ‘Futuro 2' e 'Futuro 3' para um determinado contexto social em função das escolhas político curriculares e suas ênfases. O currículo do Futuro 1, segundo o autor (Young 2011, p.267): 
(...) trata o acesso ao conhecimento como o objetivo central do currículo e assume que o leque de assuntos e as fronteiras que definem esse conhecimento são dados a priori. Tende a ser (...) um currículo para conformidade e, em casos extremos, incentiva pouco mais que memorização e memorização. Um exemplo de uma abordagem do currículo do Futuro 1 é o Alfabetização Cultural [Cultural Literacy] de Hirsch, que tenta explicitar "o que toda criança deve saber" (...). As ideias de Hirsch foram retomadas por vários grupos de direita (...) que influenciaram o Partido Conservador [Britânico]. Em 2011, tal currículo parece uma tentativa de retornar à era pré-segunda guerra mundial.

Trata-se, nota-se, daquilo que não raro clama-se como 'currículo tradicional'. Contudo, Young argumenta que pelo seu apelo aos conhecimentos como fonte de engajamento a estudantes, legitimados por comunidades de especialistas em áreas acadêmicas ou de pesquisa, ele sobreviveu nos dias de hoje particularmente em escolas de elite. Perdeu força ao longo do século XX por oferecer dificuldades a políticas de expansão de acesso e a apelos 'modernizantes' que direcionam a função da ao crescimento econômico (idem). O currículo do Futuro 2 está diretamente associado à NSE, a apelos multiculturais e pós-modernos:

Um currículo do Futuro 2 rejeita a característica 'a priori’ do conhecimento e vê o conhecimento como uma 'construção social' e, portanto, um produto de e respondendo às demandas sociais e econômicas em mudança. Impulsionado pelos objetivos de expandir o ‘acesso’ e os benefícios econômicos, o Futuro 2 rejeita a ideia de que as fronteiras entre os sujeitos, entre a escola e o conhecimento cotidiano, e entre os currículos acadêmicos e vocacionais possam expressar realidades epistemológicas. Do ponto de vista do Futuro 2, os argumentos em favor das disciplinas escolares e as fronteiras entre eles passaram a ser vistos como conservadores ou retrógrados, sendo cada vez mais tratados como pouco mais que máscaras para perpetuar o privilégio. Uma conseqüência foi o fim da idéia do currículo como (...) algo que os políticos não interferiram; cada vez mais se tornou dominado por prioridades políticas e econômicas. (...) enfrenta-nos o Futuro 1 e o Futuro 2 como alternativas polarizadas, em grande parte mas não inteiramente associadas politicamente com a direita e a esquerda.

Young esclarece que "enquanto o Futuro 1 nega a base social e histórica do conhecimento e sua organização em disciplinas e disciplinas”, o Futuro 2, ligado a correntes pós-críticas e pós-modernas, "trata as formas como o conhecimento é organizado como historicamente arbitrário e, de alguma forma, pouco mais que 
expressões de poder” (idem) - isto é, como ‘conhecimento dos poderosos', de quem tem o poder de normatividade curricular (idem).

\begin{abstract}
Argumentamos que o conhecimento é social tanto em suas origens com em seus objetivos, e é essa objetividade que se manifesta em disciplinas no currículo escolar e em disciplinas nas universidades. Essa visão da objetividade do conhecimento, que sustenta nosso modelo de Futuro 3, difere da característica 'a priori' de conhecimento associada ao Futuro 1 de várias maneiras. Primeiro, está localizado nas comunidades especializadas de pesquisadores em diferentes áreas e especialistas educacionais que recontextualizam disciplinas como base para disciplinas escolares. Como consequência, essa objetividade 'social' não é 'dada', mas falível e sempre aberta a mudanças. No entanto, ao contrário da abertura do conhecimento prevista pelo Futuro 2, essas mudanças não são arbitrárias ou apenas respostas a pressões políticas, mas ocorrem dentro de regras epistêmicas das diferentes comunidades especializadas. O Futuro 3 rejeita as características de asocialidade e 'a priori' dos conhecimentos associados ao Future 1 e reinterpreta sua objetividade social como uma ferramenta para tratar o mundo como um objeto - e assim capacitar os alunos a terem acesso à compreensão do mundo que os leva além de sua experiência. É esse acesso ao conhecimento, o qual leva os alunos além de sua experiência, que deve ser o objetivo principal das escolas.
\end{abstract}

É oportuno apresentarmos rapidamente dois exemplos de vertentes pedagógicas que tem ou tiveram influência na educação e que (com algumas ponderações) se encaixam, de uma forma ou de outra (embora não necessariamente de forma completa) às críticas de Young e outros realistas sociais ao relativismo epistêmico - isto é, currículos do Futuro 2. São elas o Construtivismo Radical - concebido pelo filósofo alemão Ernst Glasersfeld na década de 1980 - e algumas vertentes de teorias multiculturais na educação, que ganharam mais força na área a partir da década de 1990. O relativismo epistêmico que orbita estas, em suma, manifesta-se pela sobrevalorização dos conhecimentos locais ou experenciais frente ao conhecimento científico nos currículos.

O que é chamado genericamente de 'construtivismo' tornou-se influente no campo educacional principalmente a partir do fim da segunda metade do século XX. Um indício disto é o fato de termos como 'ambiente de aprendizagem construtivista', 'ensino construtivista', 'aprendizagem construtivista’ e ‘currículo construtivista’ terem se tornado 
lugar comum na literatura da área (Staver 2012, p.1021-2), ainda que atualmente não estejam em seu ápice. A influência do construtivismo em currículos também foi notada, como Matthews (2002) comenta acerca do apelo presente no documento curricular estadunidense NSES de 1996 de que a inserção da filosofia da ciência no ensino de ciências devia refletir uma filosofia da ciência construtivista (ibid., p.122). Chegou-se a afirmar que o construtivismo chegou a ser veiculado como 'novo paradigma' da prática do EC em documento assinado pela American Association for the Advancement of Science (Tobin et al., 1993, p.ix). No Brasil, segundo Vieira (2009), fatores como a aprovação da LDB, a criação dos PCN em 1997, aliados à institucionalização da proposta de ensino em ciclos, deram espaço à implementação de currículos com suporte teórico construtivista (ibid., p.26).

Dezenas de correntes construtivistas diferentes ficaram em evidência na educação desde a década de 1980, não raro acompanhadas de diferentes adjetivos - como 'contextual’, 'dialético’, 'humanístico’, 'piagetiano', 'social’, entre outros (Good et al., 1993, p.74). Frequentemente indo além de teorias de aprendizagem e epistemologia, muitas destas correntes foram e são associadas a ideias como emancipação e capacitação, e mesmo questões morais (Matthews, 1997, p.5; Nola 1997). Apesar da grande influência e do crescimento exponencial nas pesquisas em educação, os construtivismos nunca foram unânimes. Em um questionamento mais duro, Good (apud Cobern 1990, p.3) argumenta que seu rápido advento e aceitação em larga escala o fez parecer o conjunto de correntes construtivistas algo como quase uma nova religião no EC. No Brasil, nas palavras de Silva (1993, p.3), 'ameaçava’ no início dos anos 1990s tornar-se a nova ortodoxia na educação. De um olhar retrospectivo, contudo, nota-se que após seu ápice da década de 1980, a influência das correntes construtivistas passou a diminuir lentamente, cedendo espaço às pesquisas voltadas à HFC no EC (Solomon 1994, p.9).

Nenhuma forma de construtivismo na educação, contudo, foi (e provavelmente ainda é) mais criticada e polêmica que o Construtivismo Radical, associada a von Glasersfeld. Este - uma importante contribuição para o construtivismo de uma forma geral, segundo Tobin (2007) ${ }^{82}$ - teve influência parcial no desenvolvimento de teorias construtivistas no ensino de matemática e de ciências no ápice da influência construtivista na educação (Matthews 1994, p.148). A proposta de von Glasersfeld não se pretendia somente como teoria educacional, mas sim como um programa filosófico geral e abrangente. Segundo

\footnotetext{
${ }^{82}$ Vilches e Gil-Pérez (2012, p.3) argumentam que tal afirmação é bastante exagerada e idiossincrática (referindo-se a Kenneth Tobin), e que não reflete a opinião da maioria dos autores construtivistas.
} 
von Glasersfeld, as bases do Construtivismo Radical são (von Glasersfeld apud Nola \& Irzik, 2005, p.153):

1a. Conhecimento não é passivamente recebido pelos sentidos tão pouco por meio da comunicação.

1b. Conhecimento é ativamente construído pelo sujeito cognoscente.

2a. A função da cognição é adaptativa, no sentido biológico do termo, tendendo para a adequação ou viabilidade.

2b. A cognição serve à organização do sujeito do mundo vivencial, e não à descoberta de uma realidade ontológica objetiva.

A despeito da relativa razoabilidade dos três primeiros pontos acima, o último ponto se firma numa tese questionável acerca da ‘servidão' da cognição, além de fazer uso da expressão ‘descoberta da realidade’ que é bastante criticável do ponto de vista filosófico. Em suma, o ponto '2b' é o que condena o Construtivismo Radical a uma concepção individualismo-subjetivista de conhecimento, de que não há nenhuma objetividade e que os conhecimentos são inescapavelmente particulares (dir-se-ia 'pessoais'). Com efeito, Matthews (1994, p.149) critica duramente o Construtivismo Radical no viés epistemológico concluindo que esta se resume a uma "doutrina relativista", de tal forma que sua implicação curricular resultaria na exclusividade dos 'conhecimentos individuais experenciais’. Segundo o autor, uma estratégia construtivista radical muito comum é partir indiscriminadamente da premissa de que todo conhecimento é uma construção humana, historicamente e culturalmente condicionada - o que, a princípio, é perfeitamente aceitável (ibid., p.143). Desta, concluem que todo o conhecimento científico - o que inclui seus objetos teóricos e objetos reais - é ‘apenas’ (pejorativamente) uma construção humana, sem qualquer ligação com a realidade externa independente. A proximidade filosófica entre o Construtivismo Radical e filosofias empiristas e também alvo de críticas. Ainda segundo Matthews (ibid., p.150), construtivistas radicais, assim como filósofos empiristas como Locke e Berkeley, invertem a função epistemológica da experiência - ao invés de meio para o conhecimento, torna-se o fim, ou, o objeto do conhecimento. Desta forma, construtivistas radicais fazem com que a possibilidade do conhecimento sobre o mundo se perca totalmente (ibid., p.151).

Além do próprio Glasersfeld, o Construtivismo Radical contou (e ainda conta) com um pequeno grupo de defensores (Tobin 2007). Enquadrando-se entre estes, Quale (ibid., p.17-18) argumenta que construtivistas radicais acreditam que o sucesso empírico da 
Ciência não implica necessariamente que ela pode ser verdadeira, o que em filosofia da ciência é a negação do chamado 'argumento do milagre’ (ver Niniiluoto 1999), mas tão somente que as teorias científicas se mostram extremamente úteis justamente para o fim ao qual elas foram construídas. Para exemplificar este ponto de vista, Quale (2008; 2010) usa uma analogia com uma ferramenta: um martelo, por exemplo, é construído para lidar com uma tarefa específica, e não é descoberto, por acaso, como o único objeto capaz de lidar com tal tarefa (idem). Para o Construtivismo Radical, não se usa o conceito de verdade, e portanto, as teorias podem ser consideradas no máximo como 'ferramentas que se mostram úteis'. Elas emergem de diferentes 'preferências ontológicas' dos cientistas, sendo estes condicionados por contextos históricos, culturais e tecnológicos, o que não impede segundo Quale o desenvolvimento da ciência. Em suma, Quale (2007a, p.264) advoga que o relativismo epistêmico inerente ao Construtivismo Radical apresenta grande poder de explicação ao apontar o que considera como objetivo e limitações do conhecimento, e não implica em teses solipsistas ou na desvalorização do conhecimento e da ciência.

Kragh (1998, p.242) faz coro àqueles que argumentam que se deve rejeitar formas radicais relativistas de construtivismo e de sociologias da ciência, por terem muito pouco de saudável a oferecer ao ensino de ciências - o que não significa, contudo, rejeitar os importantes estudos sociais e críticos sobre a ciência (ver Greca \& Freire 2004). Sua conclusão, cara a esta tese, é que a este respeito "não se deve jogar fora o bebê com a água suja” (idem). Com efeito, é largamente reconhecido o papel dos construtivismos em se opor a pedagogias tecnicistas e tradicionalistas. Quanto às suas correntes relativistas, é importante salientar que muitos pesquisadores e autores que se consideram construtivistas em educação não coadunam com o Construtivismo Radical de von Glasersfeld, tampouco com o relativismo epistêmico de sua teoria ${ }^{83}$.

Ganhando força nas últimas décadas, teorias multiculturais na educação vieram para suprir importantes demandas de diversidade étnica, gênero, sexualidade, religião e diversas outras categoriais. Suas origens podem ser identificadas nos anos 1970s, com a

\footnotetext{
${ }^{83}$ Gil-Pérez e colaboradores (2002), por exemplo, definem construtivismo como uma abordagem em ensino de ciências que contempla a participação ativa dos estudantes na construção do conhecimento, e não simplesmente uma reconstrução pessoal de um conhecimento previamente elaborado, provido pelo professor ou por um livro didático (ibid., p.561). Defendem que o construtivismo não pode ser resumido a meras aplicações de doutrinas psicológicas ou filosóficas, como é o caso da teoria de von Glasersfeld (idem). Para Gil-Pérez e colaboradores (ibid., p.568), a principal justificativa pelo construtivismo no EC foi e ainda é a presença de modelos simplistas de transmissão e recepção do conhecimento, independentemente das concepções filosóficas de conhecimento em questão.
} 
frustação com sistemas educacionais por reproduzirem as mazelas sociais e não darem oportunidades a grupos oprimidos. Em países ocidentais, alas de esquerda que passaram pela 'virada cultural' (Rata 2015, p.109), passaram a argumentar por políticas de reconhecimento a grupos minoritários, substituindo o conceito de classe por identidade. Como apontado por Lopes (2013, p.19), estudos pós-coloniais indicaram a direção de rompimento com as chamadas qualidades eurocêntricas e coloniais - e também, como se advoga, brancas e masculinas - e impactando os currículos com apelos pelas contingências, diferenças, ou, pela identidade e cultura dos 'Outros'. As teorias multiculturais na educação, desta forma, devem ao questionamento pós-moderno às noções modernas de verdade e certeza, uma vez que isto também questiona de forma direta os conhecimentos ensinados nas escolas. De fato, não raro argumenta-se que os conhecimentos 'tradicionais' refletem univocamente tais qualidades, tornando-se opressores de conhecimentos locais ${ }^{84}$, como argumenta Rata (2015, p.112):

Com o fim de justificar os supostos 'Outros', conhecimentos disciplinares ou científicos são posicionados em comparação a conhecimentos étnicos e locais; isto é, a ciência também é concebida como um conhecimento cultural com seu potencial de servir como a ideologia de seu respectivo grupo. No caso da ciência, devido a este conhecimento ter sido desenvolvido primeiro no Ocidente, ela é classificada por autores pós-coloniais e multiculturalistas como conhecimento 'ocidental' (...). Nessa abordagem, o conhecimento de cada grupo é relativo em comparação àquele de qualquer outro grupo - e deve ser julgado apenas de acordo com seus próprios termos, e não a parâmetros universais. De acordo com teóricos multiculturalistas, todo conhecimento é o conhecimento do grupo o qual desenvolveu aquele conhecimento. E este

\footnotetext{
${ }^{84}$ A título de exemplo de tal argumentação, Paraskeva (2011) utiliza a expressão ‘epistemicídio’ para se referirem à opressão das ‘epistemologias do centro’ àquelas 'epistemologias periféricas e locais'. Com efeito, não raro discursos defendendo conhecimentos locais recaem a argumentações semelhantes a de Polanco (1985) sobre a oposição entra ‘ciência de centro’ × ‘ciência periférica’. Entre outros pontos, o autor argumenta que a polarização e a centralização da ciência em países desenvolvidos 'contradiz' a universalidade filosófica da ciência. Argumenta que a 'ciência periférica' é orientada pela 'ciência central' (europeia ocidental) - a que é tida como ‘a verdadeira’ pelas nações 'periféricas' e gera desenvolvimento aos países -, sendo que esta se expande por meio de processos de aculturação-colonização Defende que as 'ciências periféricas’ precisam tornar-se independente do ‘centro’, tendo suas próprias tradições e valores para isso, seria necessário nacionalismo e valorização dos conhecimentos locais. São questões em debate e bastante controversas. Embora parcialmente sua análise seja válida, pode-se entender que o autor não atenta suficientemente bem ao perigo ideológico do nacionalismo científico. Por outro lado, colapsar a ciência ao expansionismo imperialista capitalista a partir do século XVII e ao positivismo-cientificismo são reducionismos combatidos por Young (2016a). Repetindo um ponto anterior, a ciência não é intrinsecamente ligada ao capital, ou mercantilizada, assim como a educação também não o é. Análises críticas sugerem que qualquer noção de pesquisa ou investigação, envolve em alguma medida cooperação e trabalho conjunto - este tipo de atitude não é estritamente exclusivo do 'ocidente', de algum país ou de nenhuma parte do mundo em especial (Karpov 2013, p.35).
} 
conhecimento permanece ligado às circunstâncias sociais e históricas de seu grupo, portanto não podendo ser julgado pelos 'Outros'.

Em um contexto mais geral, o multiculturalismo não é apenas uma importante política de identidade e reconhecimento, mas vai além dos apelos envolvendo identidade e cultura, sendo também uma política de redistribuição por carregar apelos em prol ao apoio econômico e material de minorias marginalizadas (Song 2017, p.3). Envolve, por exemplo, a consciência crítica sobre a legitimidade dos estados sobre povos indígenas e o apelo pela proteção e autonomia destes (ibid., p.14). Em teoria de currículo, é proeminente o papel de Apple na defesa de um currículo multicultural no contexto estadunidense especialmente devido à forte questão racial e latina no país. Há dois exemplos centrais deste debate na educação brasileira, a saber, a inclusão do ensino de história da África e a luta dos negros no Brasil pela lei 10.639 - uma conquista positiva que era há anos largamente defendida por setores acadêmicos e movimentos sociais - e a questão da inclusão (em geral modesta, e por vezes contestada) de cotas raciais-indígenas em vestibulares. No currículo de ciências e matemáticas, as demandas multiculturais manifestam-se, por exemplo, nas defesas de inclusão de etnomatemática (d'Ambrosio 1998) e etnoastronomia. Outros exemplos na América Latina são as demandas pelo ensino bilíngue em países como Paraguai e Bolívia, de forma a valorizar e preservar as línguas e culturas locais indígenas (Schwartzman 2015, p.15). Na Nova Zelândia, por exemplo, existem apelos pela inclusão da ciência e matemática Maori nos currículos (Rata 2012, p.106) - entendidos numa oposição excludente ao 'conhecimento do colonizador’ e ‘ocidental' (Rata 2015, p.112).

Recentemente, as crises de imigração na Europa devido a conflitos no Oriente Médio e norte da África revigoraram debates sobre o multiculturalismo, ao mesmo tempo em que cresce a influência de partidos extremamente conservadores e de discursos eufemisticamente xenofóbicos (Song 2017, p.27). Disto surge uma crítica ideológicanacionalista ao multiculturalismo por defender o 'relativismo cultural' e por enfraquecer uma suposta identidade comum nacional necessária à manutenção dos estados nacionais (ibid., p.18). Nesta direção, Apple e Buras (2008, p.273) comentam o surgimento do que chamam de multiculturalismos de direita, em que setores historicamente privilegiados clamam-se os 'novos oprimidos' pelas políticas multiculturais de reconhecimento e redistribuição - segundo os autores, movimento que está na base na crescente demanda por ensino doméstico no contexto estadunidense, apoiada por grupos de direita e 
conservadores religiosos ${ }^{85}$. Por outro lado, como comenta Song (2017, p.17), o multiculturalismo também sofre críticas da ponta oposta do espectro político - como no contexto estadunidense, em que muitos que se intitulam de alas da esquerda progressista (geralmente associados ao Partido Democrata estadunidense) atacam a 'esquerda multicultural' por desviar o foco na luta por justiça econômica e social à luta por reconhecimento.

O aspecto problemático de algumas vertentes do multiculturalismo educacional para Young e outros reside em colocações epistemológicas destas. Segundo Philips e Levisohn (2012, p.46), é infelizmente comum (e fatal) que algumas correntes multiculturalistas não distingam conhecimento de crença, o que gerar confusão quando de menções a 'epistemologias locais' - ou 'epistemologias do ponto de vista' ${ }^{\text {, }}$. Estas, por exemplo, distinguem-se bastante de epistemologias fundacionistas - como o empirismo e racionalismo -, principalmente por estas serem não raro exclusivas entre si (ibid., p.47). O relativismo epistêmico de algumas correntes multiculturalistas se mostra explícito, segundo Philips e Levisohn, quando de sua apropriação do ceticismo a grandes narrativas de autores pós-modernos como Lyotard, implicando então na visão de que:

(...) a posição social ou o ponto de vista de determinado alguém (incluindo sua raça e gênero) determina o que é aceito como conhecimento, que crenças podem ser justificadas, e - em especial - como elas devem ser justificadas (...). Assim, por exemplo, é sugerido que o que conta como conhecimento e justificação para mulheres negras não é necessariamente o mesmo o que conta como conhecimento para homens asiáticos, e vice-versa. (ibid., p.50)

A partir desta consideração, Philips e Levisohn (idem) questionam: precisamente em que sentido a cultura (raça, etnia, gênero, entre outros) do proponente contribui, epistemologicamente, ao conhecimento possuído por si ou às suas atividades de criação de conhecimento? Ainda que exemplos muito isolados possam ser pinçados, não parece haver resposta geral à questão. Além disso, não é da tendência de epistemologias multiculturais relativistas ou de ponto de vista argumentarem de que há uma 'epistemologia melhor' - o que novamente poderia implicar num relativismo, desta vez de valor -, muito embora exista uma forte rejeição a epistemologias fundacionistas e

\footnotetext{
${ }^{85} \mathrm{O}$ multiculturalismo de direita está nas raízes do termo 'reverse racism', mais popular nos Estados Unidos, que tem suas origens em reações conservadoras a políticas afirmativas estadunidenses nas décadas de 1970 e 1980 (ver Spring 2010).

${ }^{86} \mathrm{Na}$ literatura em língua inglesa esse termo é conhecido como standpoint epistemologies.
} 
também, por exemplo, a epistemologias de ponto de vista antifeministas, por razões hoje bastante consensuais (ibid., p.57).

A crítica realista ao conhecimento e epistemologia multiculturais relativistas é, infelizmente, muitas vezes confundida com posturas desrespeitosas a outras culturas (Young 2016b, p.10). Não só é claro que é preciso tal respeito, mas também a consideração de que professores hoje enfrentam as novidades trazidas das sociedades multiculturais (isto é, lidando com estudantes de realidades e identidades culturais bastante diferentes) muitas vezes sem amparo. Como comenta Young (idem), uma destas novidades é o exercício necessário para separar os 'conhecimentos experienciaiscontextuais' (ou conhecimentos locais) dos conhecimentos poderosos - como exemplo, Young comenta que o conhecimento individual adquirido por estudantes sobre sua própria cidade é muito diferente do conhecimento sobre a mesma cidade propiciado pela geografia física escolar, o qual independe das (e, por sinal é anterior às) impressões individuais daqueles estudantes (idem). Também sem negar o respeito por todas as culturas e a clara influência que aspectos culturais, sociais e políticos têm no desenvolvimento histórico da ciência, Philips e Levisohn (2012, p.62) argumentam que a cultura, gênero e outras características não propiciam necessariamente a diferentes pessoas diferentes conhecimentos. Citando a filósofa da ciência Helen Longino, os autores colocam que não é preciso, por exemplo, se pensar em fazer uma 'ciência feminista', mas sim fazer ciência enquanto feminista (idem). Nesse sentido, não existiria propriamente 'epistemologias multiculturais' (no mesmo sentido das fundacionistas), mas sim o ‘fazer epistemológico com sensibilidades multiculturais' (idem) - algo, com efeito, bastante urgente e necessário à educação, das políticas públicas às práticas locais em salas de aula. O multiculturalismo educacional, enfim, não precisa necessariamente dar as mãos ao relativismo epistêmico.

Ao nível de políticas multiculturais, Rata (2015, p.108) comenta que em muitos contextos há uma distância muito grande entre a retórica supostamente multicultural (por vezes proferidas em sofismas políticos) sobre empoderamento e distribuição com os resultados concretos de tais políticas com o passar do ano. Apesar de haver avanços em situações pontuais, há casos extremamente problemáticos, como Rata (idem) exemplifica acerca das políticas sobre questões aborígenes na Austrália, seu país de origem. Todavia, um agravante sobre o uso político do multiculturalismo é que nos últimos tempos interesses neoliberais identificaram nele um forte potencial econômico - ainda que, inicialmente, defensores do neoliberalismo fossem opostos ao multiculturalismo, como 
enfaticamente alertaram Apple (2001; 2009; 2011) e outros (ver Spring 2010) no contexto educacional. A capacidade do multiculturalismo em "integrar minorias em mercados globais, fazem elas ao mesmo tempo efetivas e competitivas” é um traço do que Roose e Possamai (2015, p.101) chamam de multiculturalismo neoliberal. Como esclarece Kymlicka (apud idem) um importante autor multiculturalista:

(...) neoliberais encontraram um caminho para legitimar as etnias, e justificar políticas multiculturais que protegem projetos étnicos, e reinterpretar essas políticas alinhadas ao núcleo de ideias do neoliberalismo (melhorar a competitividade e inovação econômicas; deslocando a responsabilidade do estado para a sociedade civil; promovendo a descentralização; tirar ênfase na solidariedade nacional in favor de ligações locais ou conexões transnacionais; compreender a diversidade cultural como uma comódite econômica no mercado global).

Uma manifestação do multiculturalismo neoliberal é a solidariedade seletiva. Roose e Possamai (idem) exemplificam o caso australiano recente, no qual para imigrantes que trazem consigo iniciativas de empreendimento e possibilidades de ampliar ligações comerciais, há uma recepção entusiástica - enquanto os aspectos cívicos e culturais dos imigrantes são rejeitados ou ignorados nas políticas de governo, por não 'contribuírem' para a economia (idem). De certa maneira, e em certos contextos específicos, o multiculturalismo foi abduzido pelo neoliberalismo.

Analogamente, e mais especificamente no contexto estadunidense, interesses neoliberais também chegaram a importantes movimentos sociais, como o feminismo, formando um fenômeno social híbrido aparentemente improvável. A importante filósofa feminista Nancy Fraser (2017, p.281) argumenta que nos últimos vinte anos houve nos Estados Unidos uma abdução entre os chamados novos movimentos sociais por setores financeiros e negócios, fazendo com que ideais usualmente progressistas camuflassem políticas devastadoras justamente à classe trabalhadora e aos membros daqueles movimentos (ibid., p.282). A origem desta aliança, afirma a autora, se deu com o governo democrata de Bill Clinton - associado como 'nova esquerda' estadunidense, analogamente como o Novo Partido Trabalhista inglês -, com o no qual discurso crítico ao capitalismo deu lugar à retórica progressista de "abraçar a diversidade, o multiculturalismo, a luta das mulheres e os direitos LGBTQ” (idem). Umas das consequências de tal aliança - que ela chama de neoliberalismo progressista - é a associação de ‘progresso social’ e ‘emancipação' com meritocracia - isto é, a 
compreensão individualista-liberal destes princípios normalmente associados a teses progressistas. Esta compreensão, segundo Fraser (idem), foi tomando o lugar dos apelos anti-establishment, igualitários e anticapitalistas das décadas de 1960s e 1970s - entrando em ressonância ao fortalecimento do neoliberalismo nos anos $1990 \mathrm{~s}^{87}$.

Em sintonia ao ponto de Fraser (2017), a abdução de movimentos e discursos tidos como 'progressistas’ pelo neoliberalismo também não passa despercebido por Rata (ibid., p.109). A autora aponta que embora muitas medidas pautadas no multiculturalismo tivessem realmente intenções progressistas, “o resultado é uma convergência desintencionada entre o liberalismo cultural e neoliberalismo global (...)”, em que “[i]deologias de globalização e localismo apresentam a ideia de indivíduo despolitizado em espaços não-políticos de comunidades locais como uma alternativa aparentemente progressiva ao estado nação”. É neste sentido que Muller (2012) flerta com a ousada tese de que tais movimentos tidos 'progressistas' - em especial aqueles abduzidos pela lógica neoliberal - acabam servindo como "controle de classe” (ibid., p.326), impedindo o acesso de classes mais frágeis aos conhecimentos poderosos (Young 2016a), mas submetendo-os à regulação moral (econômica-material) da classe média. Ainda, a escolha de substituir o conceito de classe, caro às camadas trabalhadoras na era (ou fase) industrial, por grupos locais é dilemática - a valorização de culturas localizadas é, ao mesmo tempo, uma (bem-intencionada) medida de resistência e uma prática que tende a gerar uma descentralização benéfica ao neoliberalismo (Rata 2012, p.110). Segundo Rata (idem), tal descentralização:

(...) deixou parte dos membros da classe média, da classe trabalhadora e grupos sociais marginalizados com 'nenhum projeto além do consumo de comódites individuais’ como instrumento de produção da identidade social pessoal' (...). Outros, contudo, voltaram-se a projetos que se apoiam em unidades políticas pré-democráticas de formas religiosas, étnicas ou históricas de identidade a fim de preservar a coesão social. O surgimento de várias formas de culturalismo, incluindo o multiculturalismo (...) é parte deste último movimento. Conhecimentos locais fornecem o cimento social para tal coesão.

Enquanto 'cimento social', os conhecimentos locais são importantes em manter a continuidade moral e social de uma comunidade ou grupo local - e, nesse sentido, sendo

\footnotetext{
${ }^{87}$ Segundo a autora (Fraser 2017), foi o descontentamento popular com o neoliberalismo progressista que levou à eleição do republicano Donald Trump em 2017, cuja campanha e início de governo têm como uma das características justamente uma associação com menosprezo a políticas multiculturais.
} 
formas subjetivas e locais de conceber o mundo, são claramente importantes no processo social de tornar-se humano (ibid., p.113), assim como no processo de construir certa identidade ou outra (ou várias outras). Este é outro aspecto de porque os conhecimentos locais serem importantes enquanto recurso didático-pedagógico. Por outro lado, uma vez que estes estão de certa forma ligados a um imperativo geral do multiculturalismo - o de reforçar a distintividade de um grupo local e reificar sua(s) cultura(s), a(s) qual(is) é(são) por vezes tida(s) como ‘imutável’ (eis), em apelos para políticas de reconhecimento (Rata 2015, p.111) -, há um inevitável choque com culturas científicas, as quais eventualmente 'provocam outras culturas', incitam a muda-las (e também a si próprias, por sua natureza social conflitiva) (idem). Esta é a principal razão, segundo Rata, de porque o multiculturalismo educacional e teorias educacionais realistas - em especial o RS inaugurado por Young - são antagônicas ${ }^{88}$. A razão de a autora escolher o RS é argumentada com base no fato de que:

[Ter acesso ao conhecimento poderoso] leva o estudante à socialidade do
conhecimento; a uma forma de pensar que, por ser baseado em pensamentos
provisórios, não pode oferecer a garantia de estabilidade que o tradicionalismo
oferece. Em compensação, ele leva ao acesso do impensável, do 'não-ainda-
pensado' (...). Esse é o conhecimento construído ao longo de séculos através
dos esforços coletivos de indivíduos trabalhando em contextos sociais e
associando-se a outros indivíduos de acordo aos costumes sociais
procedimentais.

Por fim, o localismo epistêmico curricular pode levar a um entrave delicado, relativo ao acesso desigual ao conhecimento científico e seus impactos sociais. De fato, segundo Tilly (2006, p.53), a concentração inomogênea de conhecimento científico no espectro social, "especialmente o conhecimento que permite intervir, para o bem ou para o mal, no bem-estar humano" é um dos principais elementos que geram desigualdade (social) na história moderna - ao lado de outros mais imediatamente reconhecíveis, como a concentração de propriedades de terra. Isto por que a detenção destes conhecimentos concederia "vantagens políticas, financeiras e existências", permite a reprodução das relações e as instituições que dão sustentação às vantagens desfrutadas - um exemplo agudo de Tilly (ibid., p.57) sobre esta questão é o conhecimento relativo medicina, cuja detenção social implica fortemente sobre as possibilidades de sobrevivência dos

\footnotetext{
${ }^{88}$ Muito embora haja concordâncias pontuais entre ambos, como a tese de que a criação do conhecimento científico é dependente de seu contexto sociocultural (Rata 2015, p.111).
} 
pacientes ${ }^{89}$. Claramente, a origem desta desigualdade de concentração de conhecimento não se resume simplesmente às suas diferentes ofertas a nível educacional em diferentes países - ela tem uma raiz histórica e está associada estruturalmente a diversos problemas de ordem política, econômica, social e cultural. No sentido de Young (2016a), a oferta de acesso aos conhecimentos poderosos precisa ser imprescindível, porém é preciso atentar para o fato de que, estatisticamente, o acesso a estes - e, por exemplo, o tratamento médico de qualidade possibilitado pelo conhecimento médico-científico - correlaciona-se da renda e da riqueza (Tilly 2006, p.57). Em outras palavras, estudantes provenientes de famílias abastadas, estatisticamente, têm mais acesso aos conhecimentos poderosos - e não é nenhum absurdo entender este como um dos fatores de preservação (ou, até do alastrar) das desigualdades sociais mais gerais. Torna-se compreensível então o clamor de que estudantes menos abastados - os quais, a princípio, já têm contra si a estatística -, no mínimo, não podem ser privados destes conhecimentos, seja através de políticas curriculares localistas explícitas ou políticas que, tacitamente, acabam por caminhar a esta direção.

Tilly (ibid., p. 60-1) aponta pelo menos três argumentos-teses de natureza conservadora contra a luta pela desigualdade de concentração de conhecimento científico na sociedade. Segundo a 'tese da perversidade', “qualquer ação destinada a aprimorar algum aspecto da ordem política, social ou econômica só serve para exacerbar a situação que se busca remediar" - da qual se subentende a premissa de que a exclusividade do conhecimento científico às elites é que tem mantido o desenvolvimento histórico científico. Para a ‘tese da futilidade’, “as tentativas de transformação social são inúteis, não conseguirão reduzir os problemas” - da qual se identifica a premissa ideológica de naturalização do atual estado social, da existência 'natural' de pobres e ricos, e de que "a maior parte do mundo não tem capacidade para absorver o conhecimento ou os potenciais benefícios da ciência de alta tecnologia"90. E, por fim, a

\footnotetext{
${ }^{89}$ Procurando ilustrar este fato ainda mais, Tilly menciona as inquietantes estatísticas acerca da acessibilidade médica em diferentes países: “em 2003, Israel tinha 375 médicos para cada 100 mil habitantes, proporção não tão alta quanto a italiana (607) ou a grega (438), mas ainda assim uma das mais altas do mundo. A proporção cai para menos de um sexto da israelense, isto é, para cinco ou menos médicos por 100 mil pessoas, em Angola, Butão, Burkina Fasso, República Centro-Africana, Chade, Eritréia, Etiópia, Gâmbia, Mali, Moçambique, Níger, Ruanda, Tanzânia e Uganda” (UNDP apud Tilly 2006, p.57).

${ }^{90}$ Pode-se argumentar que este de certa forma é também o ponto de Frederic Taylor, o pai da administração científica e do taylorismo, ao afirmar que "[um] dos primeiros requisitos para que um homem seja apto a lidar com ferro fundido como ocupação regular é que ele seja tão estúpido e fleumático que mais se assemelhe, no seu quadro mental, a um boi. (...) O operário que é mais adequado para o carregamento de lingotes é incapaz de entender a real ciência que regula a execução deste trabalho. Ele é
} 
‘tese do risco’ sustenta “que o custo da mudança ou reforma proposta é alto demais, uma vez que compromete alguma preciosa conquista anterior" - o que reflete o receio de privilegiados (que detêm o conhecimento) em sacrificar suas vantagens (Hirschman apud ibid.). A estas, podemos adicionar resistências pós-modernas, as quais, embora não sejam 'conservadoras' no mesmo sentido acima, dado que com sabido muitos autores ligados ao pós-modernismo carregam bandeiras progressistas, acabam por contribuir com a desigual concentração do conhecimento científico - e, pelos pontos acima, também com a desigualdade social, ainda que de forma indireta.

A defesa pelos conhecimentos poderosos no currículo, portanto, não é meramente uma questão epistemológica, mas também social e política, como Young (2016a) e outros realistas sociais têm procurado esclarecer. O acesso aos conhecimentos poderosos não dá garantia alguma de mudança às desigualdades sociais existentes - porém, a negação de tal acesso é irremediavelmente a favor do fortalecimento delas. Os conhecimentos locais têm um papel educacional fundamental para que estudantes reconheçam a possibilidade de pontes entre seus 'mundos' e o que está ‘para além' deles. A possibilidade de construir e atravessar tais pontes, porém, só é possível com conhecimentos poderosos - eles têm o poder de 'levar além’. 'Ir além’ no sentido socioeconômico, mas também no sentido epistemológico - de conhecer uma forma de compreender o mundo diferente e (em geral) mais ampla e intersubjetiva que as formas locais, estendendo a possibilidade de diálogo com o mundo (social e natural).

\subsection{Conhecimento poderoso e justiça social - ou, sobre a importância de ir além}

Conforme explicitado em diferentes obras e artigos de sua autoria, Young teve forte influência do também sociólogo Basil Bernstein. Fundamentalmente, é em sua obra que Young e muitos outros realistas sociais buscam fundamentos teóricos para argumentar a tese (disputada na pesquisa educacional) de que existem conhecimentos 'melhores' entre os diferentes conhecimentos, e com qual(is) a escola mais precisa comprometer-se (não implicando necessariamente na exclusão dos outros, por exemplo, no âmbito didáticopedagógico). Em sua obra, Bernstein (2000c, p.155) chama as diferentes formas de

tão estúpido, que a palavra "percentagem” não tem qualquer significado para ele” (apud Mészáros 2006, p.70-1). 
conhecimento orbitantes à escola de 'formas fundamentais de discurso', vistas em geral como (destrutivamente) opostas por outros autores como Bourdieu, Habermas e Giddens $^{91}$. Uma delas seria então o discurso do conhecimento escolar ('oficial') e a outra o discurso de conhecimento local. Bernstein argumenta que, além do ácido debate com defesas e ataques há cada um destes tipos de discursos, suas caracterizações envolvem camadas a cuja conceitualização pode ser esclarecedora - apresentaremos sucintamente o resultado do esforço de Bernstein e sua influência para o conceito de conhecimento poderoso de Young e realistas sociais.

Os conhecimentos locais se tratam de 'discursos horizontais', argumenta Bernstein (ibid., p.157). Entre as várias características deste tipo de discurso, destacam-se a oralidade, a forte dependência com o contexto particular, natureza tácita e de múltiplas camadas. Também é um discurso segmentado, no sentido de refletir a segmentação das culturas existentes (idem). Segundo o autor, discursos horizontais dão origem ao que chama de 'pedagogias segmentais', pautadas na aquisição de competências comuns (locais). Os conhecimentos (locais) em questão nestas são fortemente dependentes do contexto, estão embebidas em práticas locais vigentes, estão associados a objetivos imediatos, e têm forte acento utilitarista para seus praticantes (ibid., p.159).

Bernstein distingue outro tipo de discurso, os chamados 'discursos verticais' (ibid., p.157):

\begin{abstract}
Basicamente, um discurso vertical toma a forma de estrutura coerente, explícita e sistematizada em princípio, hierarquicamente organizada como as ciências [naturais], ou toma a forma de uma série de linguagens especializadas com modos especiais de investigação e critérios específicos para a produção e circulação de textos, como nas ciências sociais e humanidades.
\end{abstract}

Diferentemente dos discursos horizontais, os discursos verticais não são organizados de forma segmental - a relação entre os procedimentos de discursos verticais não se associam de forma horizontal, mas de forma vertical, hierarquicamente (ibid. p.160). Destes dois conceitos, Bernstein apresenta suas considerações sobre o que chama de 'estruturas hierárquicas de conhecimento' e 'estruturas horizontais de conhecimento'. Enquanto em estruturas hierárquicas de conhecimento se intenta criar proposições gerais,

\footnotetext{
${ }^{91}$ É oportuno citar que para Giddens (apud Bernstein 2000c, p.156), uma destas formas de discurso é responsável por criar o que ele chama de 'sistemas experts', os quais são capazes de emergir os indivíduos de suas experiências locais (estas, por sua vez, construídas pelo outro tipo discurso fundamental). É interessante notar como o ponto de Giddens se assemelha ao de Young (2016a).
} 
teorias e modelos no sentido de integrar os conhecimentos nos 'níveis inferiores' - isto é, buscando maior integração possível entre as proposições de todos os níveis, operando cada vez mais de modo abstrato (ibid., p.161)-, estruturas horizontais de conhecimento são baseadas no acúmulo de linguagens (não traduzíveis entre si, em geral, por se fundarem em hipóteses diferentes) (ibid., p.162). Enquanto o desenvolvimento de estruturas hierárquicas de conhecimento se dá, segundo Bernstein, em escalas de integração e maior generalização, estruturas horizontais se desenvolvem, postula o autor, pela criação de novas linguagens (as quais oferecem novas perspectivas de enxergar antigos problemas, revelar novas questões) (idem). A matemática, para Bernstein, seria um exemplo de estrutura horizontal de conhecimento (ibid., p.163).

Às escolas caberia, em primeira análise, o compromisso prioritário de ensino de discursos verticais - ligados a conhecimentos estruturados horizontalmente ou verticalmente (hierarquicamente), no vocabulário bernsteiniano -, o que não necessariamente delegaria aos discursos horizontais nenhum papel educacional. Com efeito, Bernstein atenta para o conhecido fenômeno curricular acerca do "movimento de tomar conhecimentos especializados mais acessíveis aos jovens", no qual "segmentos de discursos horizontais são recontextualizados e inseridos nos conteúdos escolares" (ibid., p.169). Ainda, os discursos horizontais teriam papel fundamental no apelo pelo empoderamento de vozes silenciadas e na oposição às alegadas características de elitismo e autoritarismo dos discursos verticais (ibid., p.170). Porém, argumenta Bernstein que ainda que o movimento supramencionado possa eventualmente melhorar a experiência educacional de estudantes aproximando os conhecimentos escolares aos seus 'mundos vividos’, não obrigatoriamente levará a uma experiência positiva de aprendizagem, principalmente em razão de tais recontextualizações serem incapazes de suprir as diferenças entre os tipos de discurso e serem limitadas aos níveis operacional e procedimental de um determinado assunto. Menciona também um desdobramento possível de tal movimento em que discursos verticais "são reduzidos a um conjunto de estratégias a fim de se tornarem recursos para (supostamente) melhorar a eficiência dos repertórios disponíveis pelos discursos horizontais” (ibid., p.169).

Tal desdobramento - no qual os discursos verticais são ‘colonizados’ pelos discursos horizontais em experiências escolares - representa a mudança discursiva do vetor de legitimidade do 'conhecimento' para o ‘conhecedor', da ‘equidade’ para o 'reconhecimento da diversidade de vozes' (ibid., p.170). Isto é um dos fatores que afetam e moldam o chamado ‘conhecimento oficial’ presente em currículos em função do tempo. 
O viés de grupos e sua influência sobre políticas públicas educacionais, assim como efeitos de práticas locais em escolas, compõem outro destes fatores, traduzido por Bernstein no conceito de 'identidades pedagógicas' (2000b, p.65). A miríade de identidades pedagógicas - cujo crescimento recente foi incentivado pelas reorganizações do capitalismo no último meio século, assim como a grandes movimentações de população e pressões culturais (ibid., p.72)- é um tópico ainda em estudo por autores influenciados por Bernstein.

Esclarecimentos mínimos sobre as principais identidades são úteis para entendermos o esforço de Young (2016a) e outros realistas sociais em se posicionar contra correntes neoconservadoras e técnico-instrumentalistas: (i) Bernstein (2000b, p.67) chama de 'identidades pedagógicas retrospectivas' - as quais podemos chamar de identidades conservadoras - aquelas identidades cujo discurso é fundado em grandes narrativas nacionais, religiosas e culturais do passado, distantes do foco econômico e interessadas em projetar o passado no futuro; (ii) 'Identidades pedagógicas prospectivas’ (ibid., p.68) - ou também, identidades neoconservadoras -, embora também conservadoras, estão mais receptivas a mudanças culturais, econômicas e tecnológicas, recontextualizam elementos do passado e se caracterizam por defenderem performance economicista, assim como noções de nação, família (tradicional), responsabilidade e investimento individuais; (iii) 'Identidades pedagógicas descentralizadas tipo Mercado’ são preocupadas em objetivos de curto prazo, aplicações vocacionais, ao invés do desenvolvimento do conhecimento (ibid., p.69) - ‘conhecimento’ é tido como ‘dinheiro', e assim deve atender a 'demandas’ e ‘circular' -, prezam a 'luta da sobrevivência’ pelas ‘leis do mercado' (idem), e o ensino é entendido como voltado à produção de um 'produto com valor de mercado' - o que nos permite reclassificar esta identidade de técnica-instrumental-neoliberal; (iv) por fim, Bernstein (ibid., p.70) chama de 'identidades pedagógicas descentralizadas tipo terapêutica’ aquelas alinhadas com algumas correntes progressivistas (pós-modernas) atuais contrárias a discursos especializados .

A despeito das possíveis e eventuais limitações das categorizações de Bernstein, parte dos esforços de Young e outros autores em (re) fundar uma sociologia da educação centrada no conhecimento vêm em se diferenciar de identidades mencionadas - em especial aquelas conservadoras e neoconservadores, por também serem centradas no conhecimento (por intenções diferentes àquelas dos realistas sociais). Uma das críticas de Young ao neoconservadorismo educacional é de que este negligencia as mudanças políticas e econômicas que fragilizam seus próprios princípios, assim como negligencia a 
natureza histórica e social dos conhecimentos (científicos e escolares). As propostas técnico-instrumentalistas, pelo contrário, estão atentas a mudanças, e apelam para currículos integrados, módulos curriculares, interpretando conhecimento como conjuntos de habilidades necessárias para um determinado fim - porém, por negligenciarem os interesses internos nas origens e desenvolvimento do conhecimento e também seu valor cognitivo, Young argumenta que em suma estas acabam por fortalecer teses neoconservadoras (ibid., p.33).

Por outro lado, ambas falham em reconhecer que a organização social dos assuntos e disciplinas, base para aquisição e produção do conhecimento segundo o autor, transcende suas origens elitistas. Embora correntes pós-modernistas critiquem exatamente estes pontos, Young argumenta que, por não lidarem propriamente com o problema do conhecimento, elas fazem pouco mais do que mostrar que, infelizmente, vozes silenciadas serão sempre uma realidade em qualquer currículo (idem). Porém, isso é mais reflexo do sistema econômico elitista, desigual e excludente em que vivemos do que dos conhecimentos em si - em suma, em qualquer sociedade desigual, qualquer currículo tende a manter estas desigualdades (Young 2011, p.619)

Em sua obra Bringing Knowledge Back In, Young (2016a, p.75-6) traça assim quatro características centrais para uma teoria social do conhecimento - a qual seria a base para um currículo guiado pelo conhecimento segundo o autor. Cada uma delas é guiada por princípios-asserções que norteiam o pensamento do sociológico inglês. Algumas delas refletem teses relativamente conhecidas na literatura de HFC. A primeira delas, parte da tese de que:

(...) [o] relativismo não é necessariamente a consequência lógica de uma teoria "social" do conhecimento. Essa teoria pode, pelo contrário, constituir a base da produção de alegações de verdade e de objetividade, por via da identificação de "códigos e práticas" distintos através dos quais tais alegações são emitidas.

O segundo princípio-asserção - talvez o mais importante, e, ao mesmo tempo, o mais relativamente frágil - se apoia na tese da 'maturação' dos conhecimentos e sua progressiva independência dos contextos de origem:

Uma teoria social tem de reconhecer que algum conhecimento é objetivo de uma forma que transcende as condições históricas da sua produção (por exemplo, a geometria euclidiana e a física newtoniana). 
O terceiro princípio-asserção atenta para a importância de se levar em conta a tensão entre forças e influências internas e externas na criação e desenvolvimento do conhecimento:

\begin{abstract}
Uma teoria social que procure ligar o conhecimento aos interesses sociais tem de distinguir entre dois tipos de interesses. Estes são (1) os interesses "externos" ou contextuais, que podem refletir divisões mais vastas existentes na sociedade, e (2) os interesses cognitivos "internos", que se referem às condições necessárias à produção e aquisição do próprio conhecimento.
\end{abstract}

Por fim, uma teoria social conhecimento deve levar em conta que o conhecimento e quase sempre sujeito a mudanças, e precisa explicitar a natureza conflita em sua criação e desenvolvimento:

Contrariamente às teorias pós-modernistas, com a sua tendência para usar categorias dicotómicas como as de dominância e de exclusão, uma teoria social mais adequada tem de tratar o conhecimento como se este só fosse monolítico muito raramente ou nunca. Isto realça o valor de estudos históricos e etnográficos detalhados, que podem tornar explícito o carácter contestado dos campos intelectuais (...)

Pautado nestes princípios-asserções, Young e outros então fundaram o RS. Sua abordagem curricular caminha na direção do que 'Futuro 3' - ou seja, ortogonal às tendências neoconservadoras e técnico-instrumentalistas - e forneceria bases para:

[E]vitar tanto abordagem a-histórica do tradicionalismo-neoconservadorismo e a confiança em noções como “relevância”, “centrada em alunos” e “experiência” em decisões sobre o currículo;(...) [M]anter uma autonomia para o currículo frente ao instrumentalismo de demandas políticas e econômicas; (...) [A]preciar propostas curriculares em termos de objetivos equilibrados tais como a superação da exclusão social e ampliação da participação em “interesses cognitivos” que estão envolvidos na produção, aquisição e transmissão do conhecimento; (...) [R]eorientar debates sobre padrões de currículo desde tentativas em especificar os resultados de aprendizagem e avaliações contínuas até a identificação de interesses cognitivos e construção de comunidades especialistas necessárias, redes e códigos de prática que os suportem (ibid., p.34). 
E o que comporia fundamentalmente uma estrutura curricular tendo como base o RS, para Young, em trabalhos recentes, seria os conjuntos de conhecimentos poderosos. Enquanto um conceito ainda em construção e intenso debate (Guile, Lambert \& Reiss 2018; Young 2016a), não há propostas definitivas de definição (ou demarcação) de um conhecimento poderoso. Young apresenta um esboço contendo proposições visando cercar tal conceito, mas que de forma alguma se pretende exaustivo ou absoluto:

[1 - Um conhecimento poderoso] provê explicações confiáveis e, em um sentido brando, “testáveis” de modos de pensamento; (...) [2 - Um conhecimento poderoso] é a base para sugestões alternativas realistas; (...) [3 Um conhecimento poderoso] possibilita àqueles que o adquire verem além de suas experiências diárias; (...) [4 - Um conhecimento poderoso] é conceitualteórico, mas também baseado em evidências e experiências; (...) [5 - Um conhecimento poderoso] é sempre aberto a desafios; (...) [6 - Um conhecimento poderoso] é construído em instituições educacionais especializadas, composta por especialistas; (...) [7 - Um conhecimento poderoso] é organizado em domínios com fronteiras que não são arbitrárias, e esses domínios são associados a comunidades especialistas em termos de assuntos específicos ou associações profissionais; (...) [8 - Um conhecimento poderoso] é quase sempre baseado em disciplinas (Young apud Beck 2013, p.179).

O conjunto de proposições acima fornece uma imagem mínima possível do que representaria o conceito de conhecimento poderoso para Young - muitas delas, entretanto, pedem esclarecimentos adicionais ou especificações. A proposição sétima, por exemplo, não esclarece que, embora não arbitrárias, as fronteiras entre as disciplinas não são rigidamente fixas - em especial em domínios de grande especificidade, uma vez que são limites sociais utilizados pela humanidade à melhor compreensão dos fenômenos (Galian \& Louzano 2014, p.1118). Isto diferencia a abordagem de Young daquelas da tradição que chama neoconservadora, na qual em geral as fronteiras são tidas como fixas 'naturalmente’ ou 'por tradição'. A primeira proposição pede um esclarecimento sobre o sentido da palavra 'testável', uma vez que se pode compreendê-la de diferentes maneiras - por exemplo, em sentidos popperianos. Algumas das proposições são demasiadamente gerais, carecendo de especificações, em especial as proposições segunda e quinta ${ }^{92}$.

\footnotetext{
92 Outro problema referente às proposições é que em um primeiro contato elas parecem privilegiar muito mais disciplinas de ciências exatas do que as de outras naturezas, como as ciências sociais e as artes. Young argumenta que estes também se tratam de conhecimentos poderosos, embora o sejam por razões específicas diferentes daquelas que justificam a física o ser, por exemplo. Ver Young e Johan (2013).
} 
Exemplificando um conhecimento poderoso, Young (ibid., p.230) cita a física, que, “como qualquer outro conhecimento poderoso, pressupõe que o mundo natural é real, e que o conhecimento atual é o mais próximo que conseguimos chegar ao que a realidade é”. Porém, longe de limitar-se às ditas ciências naturais, Young aponta também as artes e literaturas nacionais e seus cânones, cujos significados estão enraizados nas condições sociais e econômicas, como conhecimentos poderosos (Galian \& Louzano 2014, p.1120), assim como a história e geografia. As colocações do autor revelam suas escolhas filosóficas acerca de importantes debates - de forma aproximada, podemos interpretar das palavras de Young não muito distante de um 'realismo do senso comum' de cientistas (ver Newton-Smith 1996), insuficientemente crítico e relativamente distante de posturas mais refinadas como o realismo científico crítico (Niniiluoto 1999) ou o realismo estrutural (ver Worral 1989; Ladyman 1998; Ladyman 2016).

Young (Young \& Johan 2013, p.237) também argumenta que o alto nível de especialização é uma importante característica de conhecimentos poderosos, pois este tipo de conhecimento especializado não é em geral acessado no dia-a-dia dos estudantes, e por isso permite-os em tese ir além do contexto local (proposição terceira). Em suas palavras:

\footnotetext{
Conhecimento especializado é emergente. (...) [Isso significa] que conhecimento especializado é produzido por condições sociais e contextuais, porém, não podem ser reduzidas a eles. Os contextos de origem podem deixar sua marca no conhecimento; que tipo de marca e quão significante ela pode ser pode depender. Contudo, o valor do conhecimento é independente desses contextos de origem e seus agentes. Se assim não fosse, se conhecimento permanecesse 'contextual', então a especialização e, portanto, a confiabilidade e também o 'poder' do conhecimento seriam em um certo sentido limitados (idem).
}

A postura de Young dialoga intensamente com as teses de Bourdieu (2001) em seu último curso. Indo em direção oposta ao relativismo epistêmico anti-objetivista de autores associados ao pós-modernismo, Bourdieu argumenta em sua obra que objetividade científica é um produto social (mais especificamente, do campo científico), e que tal natureza social não reduz em nada a validade das obras científicas (Bourdieu 2001, p.65). Tal ênfase se mostra pertinente uma vez que autores como Usher e Edwards (1994) associam tacitamente a natureza social da ciência com sua desvolarização (ideológica). Com efeito, aparentemente esta é a mesma confusão feita por alguns cientistas, segundo 
Shapin (2012, p.7), ao reagirem à afirmação frequente nos estudos sobre a ciência de que ela é 'somente’ uma 'construção social':

\begin{abstract}
Alguns sociólogos (...), insistem mesmo em que as representações científicas são "construções sociais". E ao ler isso alguns cientistas presumem erroneamente na maioria dos casos, na minha opinião - que esses diálogos tacitamente fizeram com que a frase fosse precedida do vocábulo, com ideia de valor, somente, ou de meramente, ou apenas: a ciência é somente uma construção social. Dizer que a ciência é construída socialmente é pois considerado como um modo de diminuir o valor das proposições científicas, negando que estas sejam, de maneira confiável, acerca do mundo natural.
\end{abstract}

Assim, em concordância a Young (2016a, p.73) - para quem, como exposto, a localização social-histórica do conhecimento científico (em especial nas suas origens) não implica, necessariamente, no abandono da verdade e objetividade científicas -, Bourdieu (2001, p.101) prossegue argumentando, numa clara inspiração bachelardiana, que o "conhecimento científico é aquilo que sobreviveu às objeções e pode resistir às objeções futuras" ${ }^{93}$. Tal conhecimento não se assenta nas evidências subjetivas a um indivíduo localizado naquele campo - limite ao qual uma defesa subjetivista-individualista 'enterra' a ciência, eliminando qualquer possibilidade de objetividade -, mas sim "na experiência coletiva, regulada por normas de comunicação e argumentação” (ibid., p.102). Em suma, de certa forma Bourdieu argumenta que a força da objetividade científica está em sua intersubjetividade (ibid., p.102) - algo também bastante concordante às análises de Young (2016a) -, e que o conhecimento que se mostra resistente às objeções citadas 'verdadeiro', por validação coletiva moldada pelas condições particulares históricassociais do grupo específico em questão - pode com tempo "apagar todas as marcas ligadas às condições particulares de sua emergência” (Bourdieu 2001, p.117). Isto é, o 'conhecimento verdadeiro' tende a tornar-se independente do seu contexto de origem.

Partindo da consideração que existem conhecimentos e conhecimentos, Rata (2012) argumenta que: (i) é preciso diferenciar em educação conhecimentos locais de conhecimentos poderosos; (ii) os conhecimentos locais tem uma enorme contribuição para oferecer no campo pedagógico-didático, mais do que como elementos centrais nos currículos; (iii) muitos movimentos tidos como 'progressivistas' em educação devem ser

\footnotetext{
${ }^{93}$ A inspiração pode ser notada (não, porém, reduzida) na proximidade relativa desta afirmação de Bourdieu com a máxima de Bachelard presente em sua obra La Philosophie du Non (A filosofia do não): 'La vérité est fille de la discussion, non pas fille de la sympathie' (A verdade é filha da discussão, não da simpatia).
} 
analisados criticamente, em especialmente devido suas associações com políticas neoliberais; (iv) a ciência é uma construção humana e tem raízes sociais, e sua persistência ao tempo e às diferenças dos membros dos seus campos a torna gradativamente 'independente' de suas origens e 'universal', e; (v) numa revisão crítica do ideal iluminista, é possível (e, segundo a autora, é preciso) entender o potencial de justiça social através dos conhecimentos poderosos nos currículos.

Young (Young 2016b, p.14) concorda que ambos os tipos de conhecimento têm diferentes propósitos na educação, e que os primeiros devem ter lugar especial no currículo por propiciarem levar os estudantes além de seus conhecimentos, cultura e realidade locais. Segundo Rata (ibid, p.105), pelo menos duas diferenças entre conhecimentos locais e conhecimentos disciplinares (poderosos) são:

(...) a autoridade para tal conhecimento e os procedimentos que justificam tal autoridade. (...). No caso dos conhecimentos (...) [locais] o mundo pode ser conhecido subjetivamente 'de dentro' pelo conhecedor, e tal 'forma de conhecer' precisa ser autorizada por alguém de maior status dentro do grupo social. Ciência (e por este termo eu incluo todas as disciplinas que carregam essas características) tem sua própria autoridade interna - a autoridade de procedimentos que permitem o escrutínio e criticismo.

As contribuições dos conhecimentos locais, segundo a autora, são (ibid., p.104):

(...) Primeiro, uma pedagogia socialmente responsável permite que professores atentem cuidadosamente para com seus estudantes ao compreender suas realidades social e cultural (...). Isso contribui para a motivação dos estudantes em aprender e a lidar com a atmosfera de aprendizagem em sala de aula. Segundo, a aplicação de conhecimentos disciplinares como um recurso para ajudar estudantes a compreender seu mundo de novas maneiras proporciona outra conexão entre currículo e pedagogia. Desta maneira, o currículo pode ser relevante às experiências próprias dos estudantes, muito embora o papel dos conhecimentos disciplinares não seja de 'se encaixar' no mundo das experiências individuais dos estudantes e sim o de explica-lo.

A tese de que os conhecimentos científicos - enquanto conhecimentos poderosos - são construções humanas, sociais, mas nem por isso menos objetivas e (depois de sua maturação) independentes de suas origens é um dos pilares do RS. E, tendo em mente que estes têm como características poder levar os estudantes além (de seus contextos locais, 
culturais, entre outros), a autora argumenta que a sua inclusão nos currículos é, além de uma defesa epistemológica, uma atitude política (Rata 2012, p.108):

É uma posição profundamente política porque (...) [a pessoa que detém conhecimentos poderosos] assume a autoridade para ver seu mundo de maneiras novas. É no poder de ver o mundo com olhos diferentes que o potencial de ação política está contido. Isso dá ao conhecimento objetivo um potencial inerentemente político (...). O conhecimento local contribui para reracializar os grupos sociais em formas pré-modernas de organização, confinando as pessoas ao mundo limitado e limitante da experiência [local] (...).

A natureza política da defesa dos conhecimentos poderosos feita por realistas sociais se mostra mais urgente para as camadas mais frágeis da sociedade. Rata (2012, p.113) argumenta que se aos estudantes de tais camadas (que em geral incluem minorias étnicas, grupos marginalizados, entre outros) for reservado 'apenas mais do mesmo' (isto é, 'conhecimentos locais'), as chances da gigantesca desvantagem social (a qual eles em geral já possuem) diminuir são praticamente nulas. Isto agrega ao RS um apelo de justiça social - ancorado numa revisão crítica da herança e ideal iluministas, tão criticado por autores pós-modernistas-, por meio do acesso aos conhecimentos poderosos, independente das respectivas camadas sociais dos estudantes. A ideia de que existem ‘direitos pedagógicos’ dos estudantes para crescimento individual, inclusão social e participação política, e que o acesso ao conhecimento é central para a contribuição educacional no combate às desigualdades deve-se a Bernstein. Os conhecimentos em questão, como argumentam Young e realistas sociais, são os conhecimentos poderosos e, pelo ponto de Bernstein, negar ou debilitar o acesso a estes, corolário de correntes relativistas epistêmicas na educação, seria então deixar de combater as desigualdades. Com efeito, para Lambert (2014, p.146) tanto currículos centrados em 'competências’ ou 'habilidades' (referindo-se especificamente ao uso destes termos no contexto britânico) como currículos chamados de tradicionalistas falham nesta questão (por sua retórica ‘aristocrática’ aos ‘conhecimentos clássicos’).

Especificamente no contexto educacional britânico, Young (2014b) aponta como preocupante o fato de estudantes considerados 'fracos' serem 'destinados' a currículos vocacionais, considerados popularmente como mais fáceis, o que o autor interpreta como resultado da falta de acesso a conhecimentos poderosos. Em primeira análise, essa falta de acesso para Young (idem) é um problema por isto não permitir a tais estudantes ir além 
daquilo que estão 'reservados', e que isso reforça a desigualdade educacional uma vez que 'estudantes fortes' - como salienta Young, geralmente de famílias abastadas-, continuam tomando lugares mais prestigiados na educação (e, posteriormente, na sociedade). Ciente da natureza estrutural deste problema, Young (ibid., p.35) insiste que por ser, portanto, um problema maior envolvendo a (não) distribuição de riquezas e desigualdade geral na sociedade, a escola sozinha (ou, professores sozinhos) não pode fazer 'milagres'. Haveria, no entanto, medidas locais factíveis pelos professores para lidar com esta situação - entre elas, a constante 'renovação pedagógica' em cursos de extensão oferecidos nas universidades e institutos acadêmicos, e a associação com outros professores (e, pode-se complementar, sindicatos de professores e movimentos populares) para pressionar governos e políticas públicas educacionais no sentido de diminuir a desigualdade na distribuição (direta ou indireta) de recursos educacionais (ibid., p.36) - o que envolve certamente, por exemplo, a desvalorização da carreira docente.

Tendo em mente as capacidades limitadas da escola em provocar mudanças, Young (idem) argumenta por meio de um princípio de equidade educacional que todo estudante tem direito de acesso aos conhecimentos poderosos. Nas palavras de Young (2014c, p.81), “este é o ponto inicial de qualquer sistema igualitário, justo e sensato (...), pois é baseado nos critérios mais confiáveis de 'melhores conhecimentos' que temos”. Este princípio sugeriria não diferenciar estudantes em razão de suas eventuais disposições, motivações, interesses e conhecimentos prévios (idem). Assim, negar o acesso aos conhecimentos poderosos - por quaisquer que sejam os motivos - configuraria uma violação do princípio de equidade educacional (ibid., p.82). Para Young (ibid., p.83), fazer isto, por exemplo, por meio de argumentos pela diversidade multicultural - por mais que estes estejam ancorados em preocupações legítimas com o bem estar de estudantes de minorias sociais ou étnicas-, significa não promover justiça social. É neste sentido que o autor afirma categoricamente que "[d]iferenciar currículos com base (...) em diferenças culturais e individuais se torna, na verdade, apoiar a desigualdade” (idem). E isto, enfatiza, não deve ser confundido com uma afronta ao importante princípio humanista de respeito à diversidade das experiências e culturas humanas (ibid., p.85) - o ponto para Young é que, para a educação ser emancipadora, ela deve romper com experiências individuais, não ser inteiramente pautada nestas (idem) ${ }^{94}$.

94 É extremamente importante ressaltar neste ponto diferenças entre o princípio de equidade educacional de Young e o ideal - ou melhor, a ideologia - (neo) liberal de equidade na educação, comentado esparsamente no capítulo anterior. Trata-se de uma questão muito séria que demandaria, a rigor, 
Em tom franco, e pautado no contexto do seu país, o autor sumariza que em um currículo baseado nos conhecimentos poderosos (ibid., p.84):

\begin{abstract}
(...) não promove por si mesmo justiça social ou resolve os problemas de baixo rendimento ou desigualdade; alguns estudantes continuarão a falhar ou a aprender pouco. Em termos práticos, isso convida a todas as escolas que encaram repetidamente problemas de aprendizagem a pensar novamente sobre possíveis alternativas para seus estudantes nesta situação e possibilidades de reforços, desenvolvimentos adicionais da equipe pedagógica e programas de extensão que respeitem o tempo destes estudantes não os levando a cursos que os deixe em desvantagem em suas vidas futuras. Isso, é claro, não significa que problemas de aprendizagem podem ser sempre resolvidos na escola; fundamentalmente, é uma questão de recursos. Com tudo, os pontos acima fornecem um ponto de partida para um debate sério sobre equidade educacional e o que isso significa. Muito embora o currículo deixe não resolvido questões mais amplas de desigualdade e justiça social, ele foca explicitamente naquilo que uma escola pode fazer e nos limites do que ela pode fazer.
\end{abstract}

Roberts (2014, p.133) argumenta que a necessidade da justiça social na educação emerge, por exemplo, quando de seu contexto local (britânico) se nota que "a educação (pública) conferida a 97\% das crianças da nação as deixam aquém daquelas 7\% que frequentam escolas privadas”. Argumenta a autora que equidade educacional significa prover para todos o que em geral somente os estudantes ricos têm. Assim, a missão de

trabalhos concentrados e específicos. Infelizmente, isto está além dos alcances deste trabalho, e, portanto, nos limitaremos a uma breve (e carente de esclarecimentos, em trabalhos futuros) digressão. A ideologia (neo) liberal de equidade em educação está diretamente ligada à suposição de que, garantida a mesma oportunidade a todos, os méritos individuais se devem principalmente aos esforços individuais, e, assim, tornam-se ‘justificadas' comparações e medidas de exclusividade aos merecedores (meritocracia). O que em geral se oculta é o fato da igualdade de condições ser extremamente infactível, e que ela é quebrada por uma série de fatores inter-relacionados, locais e globais - condições socioeconômicas, capital cultural familiar e individual, etnia, identidade, entre outros. O princípio de equidade educacional, de certa forma, parte do reconhecimento da pungência das desigualdades educacionais - em especial de acesso ao conhecimento -, devido a fatores sociais, estruturais, circunstanciais e também resultantes de políticas curriculares influenciadas pelo relativismo pós-moderno. Assim, a igualdade de oportunidade a todos não é em geral garantida a priori. O acesso ao conhecimento e os privilégios que decorrem disto são uma realidade mais comum a estudantes mais abastados - ainda que existam contraexemplos locais, exceções estatísticas antes de ‘exemplos de esperança' (ver Helene 2013, p.32) - do que aqueles provindos de classes sociais mais frágeis, ainda que estes por vezes se esforcem tanto quanto aqueles. Dadas estas condições, torna-se justificado que se garanta pelo menos condições mínimas de igualdade ao acesso aos conhecimentos poderosos - o que possibilita os estudantes 'irem além' -, possibilitada por currículos guiados pelo conhecimento e uma postura realista social. Em suma, como resume Rata (2012a), equidade educacional significa se mobilizar no sentido de tentar prover a todos o que em geral somente os estudantes ricos têm - enquanto isso não é possível a nível estrutural-material-social, devido à hegemonia capitalista mundial atual, devemos, no mínimo, garantir equidade oferecendo os 'melhores conhecimentos' (no sentido de sobrevivência histórica e objetividade-intersubjetividade) construídos até então por toda a humanidade, capazes de mobilizar sócio-epistemologicamente os estudantes. 
justiça social mais geral significa enfrentar problemas maiores (estruturais), tais como pobreza, exploração econômica, condições de moradia, incentivo familiar, entre outros (idem). Porém, reafirmando a colocação de Young, para Roberts a escola não pode lidar sozinha com todos estes - ainda, não tem capacidade de compensá-los completamente -, e seu papel é tentar no mínimo fornecer perspectivas melhores na vida futura dos estudantes por meio de uma boa educação (idem). O mínimo a oferecer seria os 'melhores conhecimentos', de forma a não deixar os estudantes à sorte de suas condições socioeconômicas de vida e à injustiça social (ibid., p.140).

O argumento de Young e outros realistas sociais acerca do caráter de justiça social na defesa dos conhecimentos poderosos nos currículos escolares poderia, eventualmente, não ser tão pertinente ao contexto brasileiro - pelo menos até a aprovação recente da versão definitiva do BNCC do ensino médio, no qual é dado valor secundário a disciplinas específicas como física e biologia, fixando-se no ‘bidiciplinarismo’ português-matemática e casando com a recente reforma do ensino médio brasileiro, ressonante a apelos do Banco Mundial e balizado à lógica do mercado de trabalho (Freias 2018). Assim, considerando o que podemos entender como o (re)estabelecimento do ensino vocacionaltécnico no Brasil - no discurso oficial, como 'mais uma opção', mas que coercitivamente pode se tornar a 'escolha' majoritária dos jovens - concomitante ao estabelecimento de uma base curricular comum, a despeito das inúmeras diferenças entre os contextos britânico e brasileiro, é provável que muitos desdobramentos sublinhados por Young no último decênio em seu país sejam também aqui notados (naturalmente, não 'importados', mas recriados dadas as condições e circunstâncias locais) ${ }^{95}$.

Talvez o principal desdobramento seja a destinação de estudantes 'fracos' a ênfases curriculares vocacionais-técnicas e de estudantes 'fortes' a ênfases acadêmicas. A possível correlação socioeconômica dos estudantes com estas 'destinações' há de fortalecer a desigualdade na educação (de acesso) e, por cadeia causal, a desigualdade

\footnotetext{
${ }^{95}$ É oportuno citar rapidamente o exemplo da reforma do currículo nacional britânico em 1991 a qual, fundado na retórica da ciência enquanto um campo coerente de atividade, visou a implementação de um 'curso de ciência’ no ensino básico, em oposição a cursos disciplinares em física, biologia e química (Jenkins 2013, p.147). Com efeito, mesmos os nomes das disciplinas foram evitados, propondo-se em seu lugar 'Materiais e suas propriedades', 'Processos físicos' e 'Vida e processos biológicos'. Entretanto, como comenta Jenkins (idem), na prática as três disciplinas tradicionais mantiveram seus postos nos currículos escolares. Este é um quadro possível para o futuro da educação brasileira nos próximos anos sob as políticas de reforma do ensino médio e BNCC. A problemática em si não seria a manutenção das disciplinas em si o que no caso brasileiro caminha-se para concretização se levarmos em conta o acordo dos Estados sobre um currículo único, salvo os casos dos currículos municipais de São Paulo e Sobral (https://www1.folha.uol.com.br/educacao/2018/04/estados-irao-unificar-curriculo-da-educacao-basica-communicipios.html, acesso maio de 2018)-, mas o retrocesso das políticas, na ótica realista social, por constrangerem as cargas horárias de conhecimentos poderosos como física, história, geografia, entre outros.
} 
social. No contexto britânico, há uma forte correlação entre estudantes de baixa renda (o que em geral se correlaciona por sua vez com os ‘fracos’ provindos de escolas públicas) e escolhas de temas 'aplicados' (considerados popularmente como fáceis) nos qualificadores britânicos Advance Level - e, por complementariedade, há uma alta correlação entre estudantes de alta renda (provindos de escolas particulares) e escolha de temas acadêmicos, 'puros' - (Rowbottom 2013) ${ }^{96}$.

Há poucas razões para pensar que este mecanismo tacitamente meritocrático não irá, de uma forma ou de outra, se replicar também no Brasil, um país onde a desigualdade social é ainda mais marcante. Neste sentido, Young é favorável em certo sentido a um núcleo curricular comum - como deixou claro no contexto das primeiras versões do BNCC (Macedo 2017, p. 513), ainda fora do contexto da reforma do ensino médio via medida provisória -, guiado por conhecimentos poderosos na forma de disciplinas, de forma a afastar uma desigualdade a priori de acesso ao conhecimento. Porém, enquanto por um lado medidas urgem para que esse acesso se concretize independente do contexto socioeconômico dos estudantes (o que se pode mostrar uma tarefa tão complexa quanto se possa conceber), é preciso resistir a defesas relativistas epistêmicas em políticas curriculares. Por outro lado, é preciso manter-se atento ao risco de recair-se à visão neoconservadora - a qual, no contexto britânico, segundo Young (2016a, p.60) entende os qualificadores Advance Level como:

(...) ‘o Padrão Supremo’, relativamente ao qual todos os outros currículos, devem ser avaliados. Para eles [neoconservadores], a verdadeira aprendizagem continua a ser, essencialmente, um processo contemplativo cujas raízes remontam à tradição monástica. O papel do currículo e dos exames que o acompanham é gerar respeito pelos textos canônicos, sejam eles quais forem.

A despeito do relativismo e do neoconservadorismo curriculares, a fissura criada no caso brasileiro pela reforma do ensino médio cria uma ameaça ao princípio de equidade,

\footnotetext{
${ }^{96}$ A característica meritocrática do sistema educacional britânico dificilmente é uma novidade. Ela pode ser traçada desde os primeiros sistemas de educação básica centralizados do Reino Unido no século XIX (ver Young 2016a). Porém, o relato de Arendt (1993, p.228-9), feito há mais de meio século (em 1957), é contundente e esclarecedor sobre esta questão: “Lá [na Inglaterra], ao fim da escola primária, tendo os estudantes a idade de onze anos, institui-se o temível exame que seleciona quase 10\% (...) [dos estudantes considerados qualificados] para instrução superior. (...) O que é intentado na Inglaterra é a "meritocracia”, que é obviamente mais uma vez o estabelecido de uma oligarquia, dessa vez não de riqueza ou de nascimento, mas de talento. Mas isso significa, mesmo que o povo inglês não esteja inteiramente esclarecido a respeito, que, mesmo sob um governo socialista, o país continuará a ser governado como tem sido desde tempos imemoriais, isto é, nem como monarquia nem como democracia, porém como oligarquia ou aristocracia (...)”.
} 
uma vez que, assim como na Inglaterra, o ‘currículo tácito’ de escolas particulares e instituições privadas será preferencialmente aquele contemplando conhecimentos poderosos, enquanto que nas escolas públicas o ‘currículo tácito’ será preferencialmente técnico-instrumentalista, oferecido na forma de cursos técnicos nos itinerários formativos. Por fim, Young (2016b) sublinha o cinismo de muitos personagens que bradavam bandeiras 'anticonhecimento' (isto é, alinhados aos discursos relativismos epistêmicos pós-modernistas), quando da elaboração inicial da BNCC, que preferivelmente matriculavam seus filhos em escolas e instituições privadas, nas quais teriam acesso ao conhecimento poderoso.

Naturalmente, a postura de autores realistas sociais não é isenta de críticas, e mesmo um escrutínio não muito profundo revela-lhe fragilidades. Por exemplo, é uma questão pertinente identificar as diferenças e semelhanças do discurso de 'acesso ao conhecimento' com a retórica de 'direitos de aprendizagem' presente nas políticas curriculares atuais brasileiras, em especial referentes à terceira versão do BNCC. Por outro lado, a abordagem de Young (2016a; 2016b) - à qual faz coro Rata (2012), Wheelahan (2010) e outros autores simpáticos ao RS - em separar didática-pedagogia de currículo é criticável e merece uma discussão mais apropriada como o próprio autor reconheceu (Young 2018). Estas e outras problemáticas associadas ao RS não são inéditas, e vem sendo profundamente discutidas por autores realistas sociais e seus críticos (ver Guile, Lambert \& Reiss 2018). Apesar da relevância destas e outras eventuais problemáticas, insistiremos na potencial relevância curricular do RS, e, na direção de uma sutil reformulação, procuraremos argumentar que um metaconhecimento poderoso também é importante e urgente à educação - pois, sua negação “acaba por servir os interesses dos poderosos, de uma forma ainda mais eficaz do que a propagação das ideias dominantes conseguiria obter” (Derry 2018, p.150).

\section{Segundo argumento: conhecimento sobre a ciência como um metaconhecimento poderoso - ou, um papel político para a filosofia da ciência no ensino de ciências}

Do ponto de vista filosófico, por se amparar numa forma de realismo científico, o RS está sujeito a importantes argumentos antirrealistas - como a meta indução-pessimista, o 
argumento do milagre, entre outros (ver Niniiluoto 1999; Hacking 2012; Noronha 2014; Chakravartty 2017). O insuficiente esclarecimento acerca da natureza histórica da objetividade - e sua relação dialética com a intersubjetividade - é também um ponto frágil da teoria. Neste sentido, ao não se blindar minimamente dos principais argumentos antirrealistas, entendemos que o RS, na forma como foi proposta por Young (2016a) e outros, não se auxilia no esforço de definirmos o que chamamos neste trabalho de metaconhecimento poderoso - isto é, um conhecimento poderoso sobre a ciência.

Partimos da premissa de que a importância curricular de um metaconhecimento poderoso também está atrelado a um princípio de justiça social e um compromisso de luta contra as desigualdades sociais, tal qual os conhecimentos poderosos. A princípio, boa parte das características do conceito de conhecimento poderoso pode ser transposta para o conceito metaconhecimento poderoso - especialmente, a tese de que ele pode levar além das 'experiências locais’. Como se trata de uma transposição a um nível meta, temos que ‘experiências locais’ nesse caso refere-se aos próprios conhecimentos poderosos - isto é, metaconhecimentos poderosos podem levar 'além' dos conhecimentos poderosos. Em especial, ‘ir além da ciência’ entendemos significar ir além do próprio conhecimento escolar disciplinar - isto é, ‘ir’ aos seus estudos históricos, filosóficos e sociológicos, metacientíficos, o entender enquanto construção humana situada e balizada pelos contextos em que estava inserido.

Autores realistas sociais dedicaram pouco tempo para defender a relevância educacional da história e filosofia de conhecimentos poderosos - muito embora sublinhem a natureza social do conhecimento científico e sua importância para uma teoria sociológica do currículo. Configuram-se, assim, pelo menos dois motivos minimamente plausíveis para procurarmos uma reformulação sútil do RS: (i) acomodá-lo a algumas críticas de antirrealistas científicos, e (ii) ensaiar uma reconfiguração tal que permite delimitar metaconhecimentos poderosos ao EC, dando relevância e papel político para a FC e o conhecimento sobre a ciência no EC. Para suprir o ponto (i), consideraremos uma aproximação com aquilo que é conhecido na literatura especializada de Realismo Estrutural (RE).

O RE é uma das mais conhecidas reformulações do realismo científico, e sua popularização se deve ao trabalho de Worral (1989). Numa tentativa de responder a críticas antirrealistas, em especial ao argumento da meta-indução pessimista, que enfraquece a ontologia das teorias (isto é, entidades e processos diretamente inobserváveis) e, portanto, o realismo ontológico científico - ou realismo de entidades 
(ver Hacking 2012)-, Worral (1989) argumenta que as estruturas matemáticas das teorias são preferíveis às suas ontologias, uma vez que elas tendem a 'sobreviver' em mudanças científicas (ibid., p.336), ou em 'revoluções científicas'. Isto é, a ciência (em especial as ciências matematizadas, como a física) teria continuidade matemática-estrutural ao longo de seu desenvolvimento histórico, o que introduziria certo otimismo (idem) para a visão de progresso do conhecimento científico. Um elemento interessante acoplado à analise de Worral é o caso do coeficiente de arrasto de Fresnel, derivado pelo matemático francês por volta de 1820 na ocasião de criação de uma teoria de éter luminífero parcialmente arrastado que fosse consistente com os desenvolvimentos teóricos e os resultados experimentais da época - particularmente os experimentos de Arago (ver Martins 2015) ${ }^{97}$. A insistente sobrevivência da relação do coeficiente de Fresnel $^{98}$ - ainda que ao

\footnotetext{
${ }^{97}$ Seria inócuo a este trabalho apresentarmos rigorosamente os esforços de Fresnel, a continuidade da sua contribuição matemática e as considerações detalhadas de Worral sobre a questão. Algumas considerações mais gerais e não tão exaustivas, no entanto, são uteis para entendermos as bases da defesa do RE pelo filósofo. Fresnel, no contexto do início do século XIX de desenvolvimento de uma teoria ondulatória da luz e de hipóteses acerca da interação da matéria com um suposto meio de propagação das ondas luminosas, derivou a relação matemática:
}

$$
c^{\prime}=c+\left(1-\frac{1}{n^{2}}\right) v
$$

sendo c' a velocidade da luz dentro de uma material refringente, $c$ a velocidade da luz no éter, $n$ o índice de refração do material e $v$ a velocidade (absoluta) do material em relação ao éter. À época, podia-se interpretar tal relação no sentido de que a luz é (parcialmente) 'arrastada' pela matéria em movimento no éter, ocasionando uma alteração na sua velocidade em função do índice de refração do material. A relação acima de Fresnel era condizente com uma teoria ondulatória da luz e com os experimentos de Arago e outros nos quais não se notou diferenças na refração da luz de diferentes fontes em movimento relativo a Terra. Anos depois, em meados do século XIX, o coeficiente de Fresnel foi corroborado experimentalmente em um famoso aparato de Fizeau, assim como em outros experimentos de óptica de corpos em movimento - ainda que sua ontologia (o que inclui, entre outros detalhes, a hipótese de que o éter interagia com a matéria 'parcialmente') era duvidosa mesmo para o próprio Fresnel (ver Darrigol 2000).

A partir da década de 1870, tendo como pano de fundo o programa de unificação da óptica ao eletromagnetismo de Maxwell por diferentes 'tradições eletromagnéticas', a figura de Lorentz desponta, não só por seu característico escrutínio matemático, mas também por seu dualismo filosófico (Stachel 2005), sua crença no atomismo e sua simpatia à teoria de Fresnel. Embora a ontologia esboçada por Fresnel estivesse já parcialmente abandonada, a relação matemática que derivou mantinha força, e compunha um papel central na chamada teoria eletromagnética de Maxwell-Lorentz. Sem ela, Lorentz não podia derivar o que chamava de 'Teorema dos Estados Correspondentes', resultado fundamental para o desenvolvimento da eletrodinâmica dos corpos em movimento à época. Até os últimos anos do século XIX, com o apoio de Poincaré e diversos outros pesquisadores, Lorentz ainda procurava refinar suas teorias dos campos eletromagnéticos e da eletrodinâmica e da óptica dos corpos em movimento apoiado (naturalmente, entre outras coisas) no coeficiente de Fresnel - numa ontologia, porém, já bastante irreconhecível perto àquela do matemático francês (ver Miller 1981).

Como é bastante documentando na literatura especializada, a (hoje cunhada como) teoria de LorentzPoincaré da eletrodinâmica dos corpos em movimento foi confrontada, no início do século XX, pela teoria de Einstein da eletrodinâmica dos corpos em movimento (hoje, como se sabe, conhecida como teoria relatividade especial). Ambas eram empiricamente equivalentes, os formalismos para a grande maioria dos resultados eram condizentes, porém as suas ontologias eram radicalmente diferentes. A teoria de Einstein, conforme apresentada no artigo de 1905, caraterizada filosoficamente por seus princípios e pela abordagem operacionalista (ver Martins 2005), tratava o éter como ‘supérfluo' - na teoria de Lorentz-Poincaré ele tinha um papel fundamental, ainda que os próprios autores reconhecessem sua 'natureza fantasmagórica' 
custo de ser gradativamente interpretada de diferentes formas, ou, de ter sua carga ontológica 'mudando' - não é acidental, e exprime justamente a continuidade matemática-estrutural, argumenta Worral. O custo disto, porém, é abandonarmos comprometimentos ontológicos fortes e nos apoiarmos mais na estrutura matemática das teorias do que em seus 'conteúdos ontológico-conceituais'. Nesse sentido, Worral argumenta - evitando um perigoso risco de anacronismo - que a teoria de Fresnel, embora ‘errada' (ao olhar atual), estava (quanto à derivação do coeficiente) 'estruturalmente correta' (ibid., p.340). Essa restrição ao realismo científico é, para o autor, fundamental para a sustentação de uma visão realista científica, assim como da ideia de progresso e das explicações (estruturais) corretas do mundo (idem) ${ }^{99}$. Assim, como comenta Krause (2010, p.2), o RE não nos compele à crença na descrição correta da realidade, tampouco nos compromete à ideia de que o mundo é descrito por estruturas matemáticas - e, por isso, realistas estruturais estariam livres da meta-indução pessimista e do argumento do milagre.

Worral inspirou-se filosoficamente na postura de Poincaré (ver Poincaré 1984; 1995) - quem, por sinal, é a personagem central em outro exemplo de continuidade estruturalmatemática que vamos apresentar brevemente no intuito de reforçar o ponto do $\mathrm{RE}^{100}$.

(Darrigol 2000, p.357). Apesar das ontologias selvagemente diferentes, ambas as teorias (de LorentzPoicnaré e Einstein) são capazes de derivar a fórmula de Fresnel.

${ }^{98}$ Curiosamente, em seu trabalho Worral (1989) enfatiza pouco a 'continuidade' da relação de Fresnel na teoria de Einstein da relatividade especial - tampouco na teoria geral -, enfatizando mais seu papel no desenvolvimento do eletromagnetismo na segunda metade do século XIX. Com efeito, é muito interessante notar que a teoria de Einstein, apesar de suas diferenças a nível ontológico, também deduz trivialmente a relação de Fresnel (deriva-se a expressão de Fresnel como um caso particular da lei relativística de soma de velocidades) - e, claramente, ela é interpretada de uma forma diferente de Lorentz (e Poincaré), e ainda mais diferente daquela de Fresnel. Não bastasse, tem-se ainda que a teoria da relatividade geral - fruto de grande esforço de Einstein, Hilbert, Noether e diversos outros pesquisadores -, a qual não é simplesmente uma 'extensão' da teoria especial mas sim uma teoria de gravitação relativística, também deduz a fórmula de Fresnel (Sen 1927; Kremer 1967). A rigor, este não é um resultado tão surpreendente do ponto de vista da física teórica, dado que o coeficiente de Fresnel resulta das transformações de Lorentz. Considerando que a teoria geral de Einstein se apoia no princípio de covariância geral - o qual implica que, localmente, o espaço-tempo se comporta como uma variedade lorentziana -, é esperado que tal derivação seja possível. Assim, outras teorias físicas comprometidas com as transformações de Lorentz fazem o mesmo - como a equação quântico-relativística de Dirac para o elétron (Zalesny 2009). As implicações filosóficas deste fato, porém, são muito mais instigantes e levam ao ponto central de Worral sobre o RE.

${ }^{99}$ Posteriormente, outros trabalhos de filósofos e historiadores evidenciaram outros exemplos de continuidade estrutural - mesmo em face de uma forte mudança na carga ontológica das teorias (Ladyman 2014, p.12), entre eles: aspectos da correspondência entre mecânica clássica e relatividade restrita; continuidade matemática nas teorias de elétron no fim do século XIX e início do XX; continuidade estrutural matemática entre o eletromagnetismo e eletrodinâmica quântica, entre outros (idem).

${ }^{100}$ Retrospectivamente, podemos notar a postura realista estrutural de Poincaré, não só nas suas obras de caráter mais filosófico, mas também nas próprias atitudes enquanto professor na Universidade ParisSorbonne entre 1888 e 1889 (Daston \& Galison 2007, p286-7). Em um curso que ministrou sobre teorias eletrodinâmicas, Poincaré em suas notas destrinchou as teorias de Ampère, Weber, Helmholtz e Lorentz, explicitando seus princípios e, em especial, suas entidades (cargas ontológicas). Seu esforço era em mostrar 
Nos últimos anos do século XIX, Poincaré (1898) publicou o artigo de título Medida do Tempo (La Mésure du Temps), no qual ataca a questão da simultaneidade com base no procedimento de trocas de pulsos eletromagnéticos e sincronização de relógios distantes um trabalho singular onde tecnologia, filosofia e física se cruzam (Galison 2003, p.190193) ${ }^{101}$. O raciocínio de Poincaré se pautava na relação de dupla via entre 'sincronizar relógios’ e 'calcular o tempo de transmissão' (ibid., p.185) - com efeito, para sincronizar relógios distanciados, precisa-se saber o tempo de transmissão, para saber o tempo de transmissão, precisam-se ter relógios distanciados sincronizados ${ }^{102}$. Dois anos depois, em um evento comemorativo na Holanda dos vinte e cinco anos do doutoramento de Lorentz, Poincaré apresenta um importante trabalho no qual expõe sua interpretação da variável que Lorentz chamou 'tempo local', dado em primeira ordem de $v / c$ por (com $v$ sendo a velocidade da Terra em relação ao éter):

$$
t^{\prime}=t-\frac{v x}{c^{2}}
$$

que, apesar das diferenças ontológicas e de princípios, a maioria dos resultados matemáticos obtidos eram equivalentes e condizentes com os experimentos de até então.

${ }^{101}$ Alguns esclarecimentos sobre Poincaré são úteis para entender o contexto da obra citada. Com engenheiro em atividade, era interessado em assuntos tecnológicos, como a questão da telegrafia, novidade na segunda metade do século XIX (Darrigol 2000, p.352-353). Problemas envolvendo a coordenação e sincronização de relógios distantes estavam conectados à questão da telegrafia com fio (telégrafos), e tiveram seu ápice em meados do mesmo século. Poincaré lidou com elas intensivamente durante sua estadia no Departamento de Longitudes de Paris (Galison 2003, p.40), ao qual ingressou em 1893 (à época houve vários debates técnicos sobre convenções do tempo, como a decimalização de unidades (Convention du Métre, ocorrida em Paris, 1875), meridianos (International Meridian Conference, em Washington, 1884), tempos regionais, entre outros (Galison 2003, p.174) - a convenção sobre os meridianos era de especial interesse, uma vez que o problema da determinação de longitudes era um dos mais antigos, e tinha implicações para diversos fins, como Astronomia e Cartografia). Com efeito, à época a ideia de utilizar cabos telegráficos, que cruzavam os mares em todo mundo, para se determinar longitudes por meio de trocas de pulsos eletromagnéticos, era bastante promissora. A questão, porém, é que para se determinar a longitude por telegrafia, seria preciso dois relógios sincronizados (um em um local de referência e outro no local da longitude a se determinar), nas 'pontas' de um cabo telegráfico. Desta forma, o problema torna-se a sincronização anterior de tais relógios. Um jeito 'intuitivo' de resolver isso seria levar em conta o tempo de propagação dos sinais através de todo o cabo, que poderia a princípio ser determinado por (também) troca de pulsos entre os terminais do cano. Erros de tentativas grosserias de sincronização acarretam problemas graves para o uso de cabos em cartografia, uma vez que erros de décimos de segundo (na sincronia dos relógios) podiam acarretar em erros da ordem de quilômetros nos trabalhos cartográficos (idem). Poincaré verificou este imbróglio na prática, quando da sua visita à América Latina em missão cartográfica.

${ }^{102}$ A existência deste 'ciclo vicioso' levou Poincaré a argumentar que "não temos intuição direta da igualdade entre dois intervalos de tempo" (Poincaré apud Galison 2007, p.144). Assim, defendeu que a simultaneidade deve ser definida pela troca de sinais, sendo antes estabelecida por convenção a velocidade de ida e de volta das transmissões destes sinais. Isto é, a atribuição de simultaneidade a dois eventos distanciados fica tributária de uma convenção. Esta convenção é de que "a luz tem velocidade constante, $e$, em particular, que esta velocidade é a mesma em todas as direções” (Darrigol 2005, p.11). Historiadores chamam hoje esta tese de convencionalidade da simultaneidade - uma espécie de preâmbulo da relatividade da simultaneidade. $\mathrm{O}$ fato de estas importantes conclusões terem sido alcançadas anos antes do famoso artigo de Einstein levantou diversos debates históricos - alguns deles, focados na questão da 'paternidade' da teoria da relatividade. 
Lorentz (1983 [1895]) havia proposto e trabalhado até então com a variável $t$ 'local apenas para fins de cálculo em seu longo escrutínio sobre a eletrodinâmica dos corpos em movimentos. Utilizando pela primeira vez o procedimento de sincronização de relógios em movimentos relativos ao éter - claramente inspirado no problema prático no contexto de cabos telegráficos -, Poincaré interpreta o 'tempo local' como “precisamente o 'tempo' que os relógios indicavam em um referencial em movimento quando eram coordenados pelo envio, de um para os outros, de um sinal eletromagnético” (Galison 2003, p.209) ${ }^{103}$. Lorentz incorpora esta contribuição de Poincaré em seus artigos posteriores (Lorentz 1983 [1904]), pavimentando o caminho para a construção da teoria da relatividade especial (Stachel 2005). De fato, a expressão acima reaparece nos importantes artigos de Einstein (1905) e Poincaré (1905) ${ }^{104}$, desta vez numa forma tal que, no limite de baixas velocidades, reobtém-se a equação ilustrada anteriormente:

$$
t^{\prime}=\gamma\left(t-\frac{v x}{c^{2}}\right)
$$

A interpretação einsteiniana da relação acima é bastante diferente da de Lorentz e Poincaré - isto é, as cargas ontológicas das teorias sobre a mesma equação são diferentes. Em seu artigo, Einstein destitui o éter (conforme este era concebido no fim do século XIX) como 'supérfluo', como consequência dos resultados de seus postulados e de sua rejeição dos conceitos de repouso e movimento absolutos. A interpretação em especial de Poincaré da relação acima só ficaria menos obscura em outro artigo publicado em 1908 (Poincaré 1908; Jammer 2006). Neste, calculou o ‘tempo aparente de propagação’ de um pulso eletromagnético entre dois pontos num referencial que se move com velocidade $v$ com relação ao éter, reobtendo a relação apresentada anteriormente. Diferentemente da teoria de Einstein, as concepções de tempo e espaço absolutos em Poincaré persistem implicitamente, atrelados ao conceito de éter, ainda que adotado de uma forma instrumentalista (Darrigol 2012, p.37). Em ambos os exemplos, as relações matemáticas podem ser entendidas como 'relações estruturais' que sobreviveram a mudanças de

\footnotetext{
${ }^{103}$ Em suas palavras: "Suponho que observadores colocados em pontos diferentes acertam os seus relógios por meio de sinais ópticos; que tentam fazer a correção destes sinais devida ao tempo de transmissão, mas que, ignorando o seu movimento de translação e acreditando, por consequência, que os sinais viajam à mesma velocidade em ambas as direções , se limitam a fazer o cruzamento das observações enviando um sinal de A para B, e depois outro de B para A. O tempo local t' é o tempo indicado por relógios acertados desta maneira" (Poincaré apud Galison 2003, p.209).

${ }^{104}$ Referimo-nos respectivamente Zur Elektrodynamik der Bewegter Körper - publicado no periódico alemão Annalen der Physik -, e Sur la Dynamique de l'Electron - publicado inicialmente em forma de resumo em um período italiano Nuovo Cimento, e posteriormente como trabalho completo em Comptes rendus de l'Académie des Sciences.
} 
teorias, muito embora tenha havido mudanças em suas cargas ontológicas ${ }^{105}$. Não há dúvidas que os contextos mais gerais circundantes às suas origens foram fundamentais ainda assim, podemos entender que ambas as equações não se limitam, hoje, às condições mais gerais de suas origens - elas tornaram-se de certa forma 'independentes' delas, se relacionando com outros contextos posteriores dificilmente semelhantes àqueles de suas criações.

O RS peca, conforme anunciado anteriormente, também em esclarecer suficientemente a objetividade científica enquanto um construto histórico e um par dialético com a intersubjetividade científica. E, assim como ocorre com o próprio conhecimento científico, reconhecer que a objetividade-intersubjetividade científica é enraizada socialmente - como já firmou Bourdieu (2000) -, não significa tirar dela seu valor. A história da objetividade científica atesta, em especial no século XIX, sua forte relação com contextos sociais, econômicos, tecnológicos e políticos da época, sendo objeto de pesquisa não só em círculos de acadêmicos, mas também, a título de exemplo, em gabinetes de secretarias estatísticas governamentais (ver Daston \& Galison 2007). Sendo um dos mais importantes ideais científicos - base da autoridade da ciência na sociedade -, entender a objetividade científica é entender a NdC (Reiss \& Sprenger 2015, p.3). O seu casamento com a intersubjetividade ${ }^{106}$ - e não com a subjetividade, dado a

\footnotetext{
${ }^{105}$ Podemos então entender que a ‘equação de troca de pulsos telegráficos’ de Poincaré sobreviveu à mudança científica referente à aceitação da teoria da relatividade restrita. Com efeito, com a gradual aceitação da interpretação de Einstein no meio acadêmico - e, em especial, com o impacto popular, político e científico das expedições de Eddington em 1919, somado a diversas outras hipóteses relevantes de historiadores da ciência (Kevles 2005; Brush 1999; Zahar 1973)-, a interpretação de Lorentz-Poincaré (a despeito da equivalência formal e empírica) caiu em desuso e, para o mainstream da comunidade de físicos, em esquecimento.

${ }^{106}$ Como apontam Daston e Galison (2007, p.262), a noção de intersubjetividade em questão pode ter sua origem encontrada no conceito de Mittheilbarkeit - sendo uma tradução satisfatória 'comunicabilidade'de Kant, que "o justifica com base no fato de que, se um julgamento pode ser comunicado a outros seres racionais, há uma presunção sólida (porém, não infalível) de que se comunica sobre, e de forma acurada, sobre o mesmo objeto". Popper também é lembrado por associar a objetividade científica à intersubjetividade - a veracidade de uma afirmação científica dependeria de sua falseabilidade e da sua 'testabilidade intersubjetiva' (Reiss \& Sprenger 2015, p.15). Nanda (1999, p.104) faz um apelo semelhante sobre a intersubjetividade científica defendendo o que chama de Realismo Contextual: " $O$ realismo contextual não difere muito de ler um livro escrito em uma língua que não se conhece: tal como o tradutor deste livro, uma comunidade científica compreende o significado ou a trama do livro da natureza, mediante uma troca constante entre a decifração das marcas nas páginas (observações), à luz do contexto estabelecido por outras marcas repetidas; e ele também revisa e compreende o texto através de uma nova e melhor compreensão destas marcas”. Um último comentário. A relação inseparável entre objetividade e (inter) subjetividade foi um tema aparentemente investigado por Einstein - em resposta a tentativas de conceber a objetividade científica nos moldes do conceito de invariante relativístico. Einstein afirmou que, com o objetivo de representar impressões sensoriais, condicionamo-las por fatores 'objetivos' e fatores 'subjetivos'. Para o autor, não há justificativa lógico-filosófica para essa distinção - negá-la, porém, significa cair ou no solipsismo ou no realismo ingênuo -, senão sua utilidade (Daston \& Galison 2007, p.305). Não obstante, conforme discutido em capítulo anterior, essa distinção reflete justamente a noção de
} 
capacidade de diferentes grupos de cientistas em estabelecer diferentes formas de comunicação, para o pesar do subjetivismo relativista - reflete, ao mesmo tempo, a impossibilidade de se ter com mundo de forma 'pura' e a capacidade de identificar relações invariantes entre sensações e ideias - as quais, sozinhas, são não fidedignas e pouco significativas (ibid., p.253). Nessa direção, os conceitos científicos não possuem representação direta com o que eles representam, sendo que seu poder manifesta através das conexões ou relações com outros conceitos (Derry 2018, p.140). Isto nos leva à definição de objetivismo estrutural ${ }^{107}(\mathrm{OE})$, surgido no início do século passado entre filósofos e matemáticos - entre eles Poincaré e Helmholtz - e compondo-se enquanto uma tradição ainda bastante viva na FC (ibid., p.259):

\begin{abstract}
Objetividade, de acordo com os estruturalistas, nada tinha a ver com sensações ou mesmo com coisas; não tinha nada a ver com imagens, feitas ou mentais. Se tratava de trabalhar sobre relações estruturais que sobreviveram a transformações matemáticas, revoluções científicas, mudanças de perspectiva linguística, diversidade cultural, evolução psicológica, às curvas da história, e aos caprichos das fisiologias individuais
\end{abstract}

Longe de ser um campo sem contestações, tanto o RE como o OE sofreram críticas e propostas de reformulações (ver Ladyman 2016; Reiss \& Sprenger 2015). Especialmente sobre o RE, argumenta-se sobre a dificuldade de se adequá-lo em ciências menos matematizadas - como a biologia, por exemplo. O risco da indistinguibilidade entre estruturas físicas e matemáticas em teorias e modelos físicos é também algo criticado no RE (Ladyman 2016). Em outra importante crítica argumenta-se que o RE, limitado à sua versão epistêmica, não se difere de uma espécie de realismo científico usual (ver Ladyman 1998). Tais críticas vêm sido trabalhadas de diferentes maneiras - propostas realistas estruturais em biologia, por exemplo, têm sido recentemente intentadas 108

conflito entre objetividade-intersubjetividade - e, não sendo necessariamente um problema à ciência, esta distinção se revela, com efeito, um traço imprescindivelmente humano. Recuperando o argumento do capítulo anterior, tem-se então que a consciência disto é um passo fundamental para uma compreensão crítica sobre a ciência.

107 Contudo, apesar da semelhança dos nomes, o objetivismo estrutural não é necessariamente harmônico ao realismo estrutural (Daston \& Galison 2007, p.261) - não, pelo menos à forma mais forte deste, conhecido como RE ontológico ou ôntico (sobre estruturas) (ver Ladyman 2014). Trabalhamos com a versão mais 'fraca' do RE - a forma epistêmica, próxima à defesa de Worral (1989) -, no qual, em simples colocações, não afirma que o que 'há' são relações estruturais, mas que 'o que se pode conhecer' (do mundo) são relações estruturais.

${ }^{108}$ Derry (2018, p.141) lembra que o conceito de gene só faz sentido dentro do sistema de conexões com outros conceitos biológicos - um possível exemplo de como o RE se manifesta nas ciências biológicas: "A investigação profunda da história do conceito [de gene] revela o seu emaranhamento indissolúvel com 
(French apud ibid., p.43), e a tese de que a matemática é o estruturante do conhecimento físico (ver Pietrocola 2002) pode ser considerada no sentido de esclarecer os diferentes papeis destes conhecimentos dentro da física, especialmente no EC. Os ataques à objetividade científica receberam mais destaque - como as obras de Feyerabend, quem rejeitou duramente seus ideais de neutralidade e isenção de valores em nome de uma ciência democrática a serviço da sociedade (Reiss \& Sprenger 2015, p.35). Outro importante conjunto de críticas veio de filósofas feministas, ao argumentarem que a ciência carrega ainda valores androcêntricos - em especial em teorias sobre sexo, gênero e estupro (ibid., p.32) -, e, assim, a objetividade científica não deve ser entendida como um ideal socialmente neutro e isento de valores ${ }^{109}$. De fato, é completamente inócuo exigir a neutralidade absoluta no empreendimento científico, o que inclui sua objetividade, ponto este que críticos do pós-modernismo alegam passar despercebido por relativistas (Nanda 1999, p.103).

Em suma, tanto o RE e o OE são propostas interessantes e plenamente defensáveis do ponto de vista histórico-filosófico, e são abertas a críticas que eventualmente levarão ao se desenvolvimento. Do ponto de vista educacional, argumentamos, eles têm potencialmente um papel positivo a contribuir ao RS e ao EC. E, neste sentido, entendemos ser positivo ensaiarmos uma extensão do RS para um Realismo Social Estrutural (RSE) - ainda que este exercício se mostre passível de críticas, reformulações e refutações, dado, por exemplo, que sua abordagem privilegiará disciplinas matematizadas, como a física. Ainda que, por um lado, a defesa de uma ênfase realista científica não seja uma novidade no EC (ver Aduriz-Bravo 2007; Barra 1998; Matthews 1994; Matthews 2012), dificilmente se sublinha a importância do reconhecimento da socialidade do ciências para visões realistas - justamente um dos pontos centrais no RS, carregado adiante no RSE.

Como primeira aproximação, podemos afirmar que para o RSE: (i) os conhecimentos poderosos tem enraizamento social e cultural, histórico; (ii) a socialidade e a historicidade destes conhecimentos poderosos é a base para sua objetividade-intersubjetividade; (iii) sendo também um construto histórico e social, a objetividade-intersubjetividade não é

as conexões sistemáticas que o constituem. Quando as duas versões de um conceito (um herdeiro do préformacionismo e o outro de sua gênese) são confundidas, seu poder produtivo é perdido. O significado do conceito 'gene' é constituído pelo sistema particular de conexões do qual faz parte e, sem a iniciação nesse sistema, o estudantes só aprenderão mecanicamente e não conseguirão dominar os conceitos envolvidos”

${ }^{109}$ Isto é, defender a objetividade-intersubjetividade não significa necessariamente defender a tese (ultrapassada) da neutralidade cientifica geral (social, epistemológica, religiosa, entre outras dimensões) um dos pontos característicos da visão positivista-cientificista, discutida em capítulo anterior. 
isenta de valores culturais, políticos, morais e outros condicionantes contextuais; (iv) esta objetividade-intersubjetividade é estrutural, no sentido de que são nas redes de conceitos e ou nas relações matemáticas estruturais onde repousa sua força epistêmica; (v) conhecimentos poderosos possuem cargas ontológicas, que dependem tanto de fatores 'internos’ como 'externos’ à ciência, porém, em mudanças científicas, estas tendem também a mudar, enquanto o sistema de conexões e relações matemáticas estruturais tendem a continuar; (vi) embora construtos sociais e históricos, o sistema de conexões e as relações estruturais e os conhecimentos poderosos associados tendem a amadurecer, e tornarem-se lentamente 'independentes’ dos contextos gerais de origem, e, por fim; (vii) conhecimentos sobre conhecimentos poderosos são metaconhecimentos poderosos, dado que sua historicidade (expressa tanto na sua dependência contextual em suas origens, como em seu desenvolvimento sócio-histórico por meio de sua 'sobrevivência' e 'maturação' em mudanças científicas) e sua objetividade-intersubjetividade são suas características centrais. Isto é, este último ponto remete ao próprio RSE enquanto metaconhecimento poderoso.

Estas condições preliminares implicam a contornos não muito diferentes daqueles propostos por Young e outros realistas sociais ao conceito de conhecimento poderoso (Young apud Beck 2013, p.179). Já as caracterizações de metaconhecimento poderoso são particulares e em geral não são idênticas aos do conceito anterior. Num exercício de delimitação inicial, um metaconhecimento poderoso: (a) provê descrições equilibradas e confiáveis sobre os conhecimentos poderosos; (b) pode ser entendido como uma base para outras teorias de currículo que levem em conta o caráter sócio-histórico dos conhecimentos poderosos e da objetividade-intersubjetividade; (c) possibilita aqueles que o adquirem irem além dos conhecimentos poderosos; (d) é baseado nos próprios conhecimentos poderosos, amparado por evidências e apontamentos de autores da HFC; (e) é, como qualquer conhecimento sobre a ciência, aberto a desafios; (f) é construído em instituições educacionais especializadas, composta por especialistas, desta vez em campos associados à HFC; (g) pode ser associado a domínios e fronteiras, e estas a comunidades de especialistas, porém não raro há intersecções com outras áreas de conhecimento, e; (h) podem ser disciplinarizados, mas nem sempre são transposições das disciplinas associados aos conhecimentos poderosos, principalmente por abrangerem diversas outras áreas de conhecimento (história, filosofia, sociologia entre outros).

Entendemos que o RSE - enquanto um metaconhecimento poderoso-, tem um papel importante a desempenhar no EC, funcionando como um balizador curricular histórico 
filosófico - não tão restrito como pode parecer, dada a relativa diversidade filosófica presente entre autores que defendem o RE - e oferecer resistência ao relativismo epistêmico e sua influência sobre políticas curriculares. Isto não significa, como se intentou esclarecer anteriormente, negligenciar completamente os conhecimentos locais e multiculturais - associados, nem sempre justamente, a posturas relativistas - nos currículos, mas sim esclarecer melhor seus papeis mais interessantes à educação e EC. A postura de realistas sociais e de Young é de enfatizar que a finalidade das escolas envolve o ensino e aprendizagem de conhecimentos poderosos, e os meios para isso podem (e devem) contar com conhecimentos locais. A inversão do vetor - isto é, quando se entende a finalidade da escola como o ensino e aprendizagem de conhecimentos locais tão somente - implica ferir a equidade no acesso a conhecimentos poderosos, e isto, por sua vez, reflete um aspecto de injustiça social, dado a possibilidade de mobilidade social (em especial a estudantes não pertencentes à elite econômica) e epistemológica que estes trazem. O princípio de equidade educacional - ainda que falho e difícil de concretização é seguramente um elemento imprescindível ao espírito democrático (Wheelahan 2010, p.2), enquanto que a 'democracia relativista' - analogamente ao temor registrado de Gramsci (apud Muler 2012, p.334) quanto ao vocacionismo burguês da Escola Nova destina-se “não apenas a perpetuar diferenças sociais, mas a cristalizá-las”. Como resume Wheelahan (2010, p.16):

\footnotetext{
Conservadorismo remete conhecimento à tradição, construtivismo ao poder e práticas sociais, e técnico-instrumentalismo à utilidade. Para estes, as características do conhecimento são menos importantes que os propósitos aos quais eles pode servir (...). O cerne da educação é prover aos estudantes acesso [aos conhecimentos poderosos] de forma que consigam participar do diálogo [com a sociedade e o mundo], e isto é o motivo central do acesso ao conhecimento ser uma questão de justiça distribucional, e do acesso justo ser necessário à democracia.
}

Como já comentado, a postura de Young (2016b, p.4) tem sofrido represálias devido à sua postura provocativa a tendências características de ambos os lados do espectro político clássico - em particular os ideários de que respeito pelo conhecimento é 'de direita’ e ênfase no estudante e multiculturalismo é ‘de esquerda’. Muler (2012, p.325) sublinha o fato de que dentro do progressivismo educacional pós-moderno - o qual insiste em resguardar para si a exclusividade da retórica de justiça social -, tende-se a classificar automaticamente seus opositores como 'tradicionalistas' ou 'conservadores'. Do outro 
lado, como já se comentou, posturas preocupadas com ideais de justiça social, antimeritocracia, justificação sócio-epistemológica do conhecimento - e, por exemplo, críticas a visões ideológicas (cientificistas, religiosas, centradas na lógica capitalista, entre outros) - são vistas, como no caso do EsP, como 'doutrinação esquerdista'. Dialogando Young com Arendt, a educação seria para estes autores, por um lado e de certa maneira, 'conservadora' - o que está muito distante de um conservadorismo político, que apenas “aceita o mundo tal como ele é e luta unicamente por preservar o status quo” (Arendt 1993), ou mesmo do neoconservadorismo educacional, que não é motivado por preocupações epistemológicas ao defender disciplinas tradicionais, mas sim com base na autoridade e proteção de valores tradicionais (Young 2016a, p.61). 'Conservadora' no sentido de se responsabilizar por introduzir os estudantes a algo pré-existente e além de seus contextos locais - conhecimentos poderosos, objetivos-intersubjetivos, construções humanas, frutos de seus contextos sociais e que sobreviveram até então ao tempo, isto é, 'conservados' -, também, no sentido de conservar o 'mundo novo' do 'mundo velho', e vice-versa. O segundo representa todo o conjunto de problemas acumulados - incluso, por exemplo, as crescentes desigualdades e tragédias sociais -, e também nossos maiores legados enquanto humanidade. O primeiro representa a promessa de mudança sobre o segundo, de preservação de legados e construção de novos. A educação, incluindo o EC, estaria justamente no cerne deste conflito - representado nos pares conservar-mudar e novo-velho-, entre reproduzir o 'velho' e engendrar o 'novo'110.

Tensão semelhante manifesta-se também nas origens da escolarização comum, como aponta Young (2011, p.620):

A escolarização comum, com o objetivo de maximizar o desenvolvimento intelectual de todos os estudantes, pode ser considerada uma instituição como a ciência, a democracia e os sindicatos. Nenhuma delas realizou plenamente os objetivos que lhes são associados, mas nenhuma é apenas produto do capitalismo ou do colonialismo e suas divisões. A escolarização comum surgiu, em parte, das necessidades de um capitalismo industrial em expansão e das desigualdades de classe social geradas por ele. Contudo, foi também um

${ }^{110}$ Young (2016a, p.66-7), nesse sentido, exprime sua visão - facilmente mal interpretável - de que o neoconservadorismo educacional tem falhas, mas não é absolutamente falso: "Ela relembra-nos que (1) a educação precisa de ser vista como um fim em si mesmo e não apenas como um meio para se atingir um fim (a posição instrumentalista) e que (2) a tradição, embora possa preservar interesses encobertos, também é crucial para se assegurar a manutenção e o desenvolvimento de padrões de qualidade na aprendizagem escolar, sendo também uma condição necessária para a inovação e a criação de novo conhecimento. Mais genericamente, os neoconservadores recordam-nos que o currículo tem (...) de procurar concretizar 'o que de melhor se tem pensado e conhecido em todo mundo'”. 
produto do Iluminismo do século XVII e dos valores de universalismo e igualdade a ele associados. As escolas e o currículo, assim como instituições políticas tais como a democracia e os sindicatos, estão em constante tensão com seu contexto. Não são apenas produtos desse contexto.

Contudo, o intuito de Young e outros realistas sociais não é ressuscitar o Iluminismo em pleno século XXI, nos moldes originais. O autor esclarece (Young 2016a, p.184) explicitamente que é preciso ponderar alegações epistemológicas de filósofos iluministas sobre conhecimento e o conceito de verdade, por exemplo - da mesma forma como é preciso ponderar as alegações pós-modernistas relativistas. Mais importante, é preciso também ponderar sobre as teses iluministas individualistas e a-históricas acerca do conhecimento e razão, e sua tendência a orbitar somente as ciências naturais (idem) características estas que, por exemplo, orientaram a tradição curricular instrucional de Bobbit e a noção ideológica liberal de equidade (Young 2015, p.830). A falta de atenção sobre a possibilidade destas ponderações leva ao reducionismo total de qualquer proposta inspirada - porém, também crítica - sobre ideais iluministas ao conservadorismo ou ideais mercadológicos (ver Macedo 2017).

O objetivo educacional mor do RS - e, por transitividade, um dos objetivos do RSE -, é maximizar as chances dos jovens em acessar os conhecimentos poderosos, independentemente das suas condições socioeconômicas, de suas etnias, gêneros, identidades, entre outros (ver Deng 2015). Tal objetivo representa um compromisso com a justiça social e com o princípio de equidade, e a tese de que todos têm direito de acesso aos conhecimentos poderosos, das grandes metrópoles até pequenas comunidades (Galian \& Louzano 2014, p.1121) ${ }^{111}$. Isso explica a defesa de Young a currículos guiados pelos conhecimentos poderosos, e sua simpatia à ideia de um currículo nacional e à organização do conhecimento escolar em disciplinas. O RS, por si só, tem potencial de contribuição ao EC, a despeito de suas limitações e fragilidades, em atual discussão seus propositores e

\footnotetext{
${ }^{111}$ Isto não pode ser confundido com a retórica de 'direito de aprendizagem’ propalada nos discursos referentes à terceira versão da BNCC - nos quais, implicitamente, se estabelece um 'direito de avaliar' pautado na lógica de accountability neoliberal (Macedo 2017, p.513). Por outro lado, dificilmente se pode entender que este BNCC é condizente com a proposta de Young - como defendido por Macedo (idem) uma vez que é guiado mais pela noção de empregabilidade, explícito nas competências e habilidades gerais. Caso a BNCC fosse guiada pelo conhecimento - pelo seu poder de mobilidade social e epistemológica, e não suas utilidades ou usos pragmáticos -, certamente não seria reservada uma parcela tão significativa da carga horária do ensino médio aos (ainda pouco esclarecidos) itinerários formativos. Por enquanto, a hipótese mais provável e que estes servirão de antro para cursos vocacionais, voltados à prestação de serviços, o que será certamente mais ocupado por estudantes pobres - os quais, assim, serão ‘salvos' pela 'resiliência’ (uma das competências gerais do documento) (ver Freitas 2018). Assim, toda a carga de 'conhecimento' nos outros dois terços do currículo seria apenas um subterfúgio, no máximo uma ‘preparação’ para estes.
} 
críticos (Guile, Lambert \& Reiss 2018). Nossa modesta complementação às teses sóciorealistas, enfatizamos, envolve: (i) estender o apelo de acesso, desta vez aos metaconhecimentos poderosos no EC, e; (ii) fundar a resistência ao relativismo epistêmico no EC numa filosofia realista estrutural social e preservação do princípio de equidade e do apelo de justiça social educacional distribucional ${ }^{112}$. Assim como fizemos mais especificamente com a HC ao EC no capítulo anterior, pretendemos assim também fundar parcialmente a relevância da FC ao EC em teorias de currículo, dando-lhe um papel também político além daqueles epistemológicos já reconhecidos.

\section{Argumento}

O conhecimento sobre a ciência no ensino de ciências deve ter ser entendido como um metaconhecimento contra correntes relativistas epistêmicas na educação, associadas a desvalorizações ideológicas da ciência e potencialmente influentes em políticas curriculares localistas. Um metaconhecimento poderoso, ancorado numa visão que reconheça a socialidade do conhecimento científico sem negar sua objetividadeintersubjetividade. Tal visão pede uma postura filosófica realista - social estrutural -, a qual por sua vez impõe restrições quanto ao conteúdo metacientífico em abordagens sobre a ciência em currículos, particularmente no que diz respeito a ênfases relativistas $e$ subjetivistas acríticas. O conhecimento sobre a ciência enquanto um metaconhecimento poderoso é comprometido com um ideal de justiça social no sentido de um combate à desigualdade de acesso a conhecimentos poderosos, e pode levar além destes - às suas histórias e filosofias, às suas culturas. A filosofia da ciência - dentro da pluralidade que visões realistas estruturais englobam - assume o papel no ensino de ciências de resistência ao relativismo epistêmico.

\footnotetext{
${ }^{112}$ Vale citar que o princípio de equidade proposto por Young e outros encontra respaldo, por exemplo, em alguns aspectos do diagnóstico de Helene (2013) sobre a educação brasileira e seu financiamento nos últimos anos. O autor lembra, algo infelizmente não surpreendente, que há correlação positiva na renda individual e a quantidade e qualidade da educação formal - e, dado que a educação de jovens depende fortemente da renda familiar, instaura-se um círculo social vicioso (Helene 2013, p.29). O autor (ibid. p.90) enfatiza a conclusão já sabida (porém, infelizmente pouco concretizada por sucessivos governos), de que não se superará “as desigualdades (de renda, regionais e de possibilidades de inserção social) sem, entre outras coisas, termos um sistema educacional igualitário e democrático”.
} 


\section{Tensões inevitáveis, ponderações e considerações finais}

Ao construir um currículo escolar de ciências, estamos mesmo diante de uma escolha acirrada entre o tradicional e o pós-moderno? Estamos mesmo obrigados a escolher entre, por um lado, a imagem de um cientista como um buscador-de-verdades implacável, coletando pacientemente dados dos quais as conclusões serão tiradas, quando todas as evidências estiverem à mão, e por outro, de um 'oportunista ágil que mudará táticas de pesquisa, e talvez até mesmo toda a agenda dela, conforme o momento exija' (...)? Qual visão é a mais autêntica? Igualmente importante: o que devemos dizer aos estudantes? Quais são seus interesses? Há alguns anos, Stephen Brush (...) colocou a questão: ‘deve a história da ciência ser censurada?’ A questão é também pertinente para a filosofia da ciência e a sociologia da ciência. Devemos expor os estudantes à epistemologia anarquista de Paul Feyerabend? Devemos abrir a caixa de Pandora que é a sociologia da ciência? Os estudantes seriam prejudicados por uma exposição precoce a esses pontos de vista? Quando procuramos questionar (e possivelmente rejeitar) as certezas da visão tradicional da ciência, ficamos sem orientação firme, sem padrões e sem significado compartilhado? O reconhecimento da bagagem sociocultural da ciência implica automaticamente numa visão de ciência como apenas um artefato cultural, entre muitos outros, sem nenhuma reivindicação particular de nossa fidelidade? É possível algum tipo de compromisso entre esses extremos e entre essa diversidade? Podemos reter o que ainda é bom e útil sobre a 'velha' visão da ciência (como clareza conceitual e testes rigorosos) enquanto abraçar o que é bom e útil no novo (como a sensibilidade à dinâmica sociocultural e a consciência da possibilidade de erro, fraude e uso indevido da ciência)? O currículo pode alcançar um equilíbrio aceitável para a maioria das partes interessadas? Em resumo, que itens específicos de todos os argumentos e contra-argumentos constituiriam uma seleção educacionalmente apropriada e ensinável? (Hodson 2014, p.919)

Pode-se entender que as questões levantadas por Hodson, a princípio, são extremamente pertinentes, não apenas porque urgem serem respondidas, mas também porque mostram que suas possíveis respostas não estão isoladas entre si. Contudo, é preciso ir além de questões mais ligadas à epistemologia da ciência. A escolha acirrada de 
uma ênfase curricular entre os extremos ‘tradicional' e 'pós-moderno' tem consequências, procuramos argumentar, também sociais e políticas. Nesse sentido, também se justificam outras perguntas, em especial, aquelas que guiam retrospectivamente pontos discutidos neste trabalho. Entre tais extremos, qual ênfase curricular é mais coerente com objetivos de justiça social? Qual oferece uma visão mais crítica sobre ciência, sua socialidade, historicidade e objetividade? Qual pode potencialmente fornecer subsídios para combater tanto valorizações ideológicas (positivismo-cientificismo) como desvalorizações ideológicas (relativismo epistêmico) da ciência? Que tipo de ênfase coaduna desmedidamente com políticas neoconservadoras, e qual com políticas técnicoinstrumentalistas? Como determinada ênfase pode, de uma forma ou de outra, oferecer resistência a processos político-sociais 'maiores', de mercantilização e privatização da educação, por meio da forma e conteúdo de suas abordagens sobre a ciência?

Em síntese, de determinados ângulos, este trabalho pode ser em parte entendido como mais um dentro de um extenso grupo de obras críticas à VCNdC na área de pesquisa em EC. Diferentemente de uma particular tendência nesta direção, não procuramos, porém, 'redidatizar' a NdC e a HFC - isto é, apresentar explicitamente propostas alternativas sobre suas abordagens ou conteúdos, ou ainda reformular os seus fundamentos teóricopráticos, exercícios importantes e laboriosos aos quais diferentes autores se propuseram. Não se pode desprezar a importância geral da construção de uma visão consensual para ao processo amadurecimento de um tema de pesquisa e seus correlatos, e também aos seus impactos ao EC. Paralelamente o escrutínio crítico deve ser sempre mantido, de forma a manter tal processo contínuo. É imprescindível, porém, que haja também esforços no sentido de explorar as implicações sócio-políticas mais gerais de se defender a $\mathrm{NdC}$ e a HFC nas salas de aulas de ciências - seja no nível básico como no superior, nas dimensões didáticas ou curriculares - e de propor medidas ou recompreensões sobre questões problemáticas ou mal resolvidas. Isto, porém, infelizmente é algo muito pouco contemplado na literatura especializada. Chamamos de 'miséria da NdC'.

Os argumentos apresentados nesta tese estão longe de livrar-se de críticas, ponderações, e é provável que uma fração de suas fragilidades - além daquelas mais imediatas - está por ainda se revelar. Por outro lado, dificilmente não se nota tensões inevitáveis entre os argumentos, tanto em suas expressões em si como em seus fundamentos teóricos e empíricos. Numa dimensão filosófica, por exemplo, tensões entre o neomarxismo de Apple e o RS de Young parecem evidentes. Outras tensões se manifestam, também, nas diferentes trajetórias acadêmicas e políticas dos autores. 
Enquanto Apple é ainda muito associado a teorias críticas de currículo - mesmo com suas tímidas aproximações a teorias pós-críticas -, a recente virada de Young - outrora um dos ícones centrais da NSE britânica - o coloca num terreno de difícil delineação por outros teóricos de currículo, embora seja explícita sua distância a teóricos pós-críticos. Suas escolhas políticas, superficialmente, parecem incompatíveis - um olhar mais cuidadoso, entretanto, revela certa ressonância na preocupação para com as crescentes desigualdades sociais, com as críticas a alas progressistas pós-modernas e também às tendências neoconservadoras e técnico-instrumentalistas educacionais. O papel do conhecimento no currículo, todavia, talvez seja o ponto mais agudo de conflito entre ambos. Por um lado, Apple nos ensinou a importante pergunta sobre 'de quem é o conhecimento' - "whose knowledge?” - em questão, quais os impactos de um conhecimento ‘oficializado' nos currículos, e suas associações a políticas educacionais neoliberais, avaliações padronizadas, desrepresentatividade curricular e (re) produção das desigualdades sócioeducacionais. Já Young, que num primeiro momento sublinhou pontos semelhantes a Apple, hoje procura alertar que é preciso diferenciar entre conhecimentos locais e conhecimentos poderosos, e que podem ser encontrados critérios razoáveis e críticos para fazermos tal distinção. Procuraremos explorar rapidamente alguns estes pontos no que se segue.

Ainda que o materialismo e marxismo de Apple não sejam iguais ao materialismo e marxismo de Marx (Banfield 2015, p.145), do ponto de vista filosófico, cabe sublinhar que não necessariamente o marxismo é ortogonal a correntes realistas científicas. Com efeito, segundo Skourdolis (2009, p.259), a própria visão de Marx sobre a ciência à sua época era compatível com uma visão realista epistemológica, de que as verdades científicas não são (em todas as suas dimensões) absolutas, que o pensamento científico carrega em si uma filosofia materialista não reducionista e que a ciência é uma atividade social associada às condições materiais e econômicas ao seu redor. Ainda segundo este autor, autores associados à primeira geração da Escola de Frankfurt e outros marxistas notáveis como György Lukács, defendiam inicialmente que Marx "não acreditava que o mundo natural existia independentemente do nosso conhecimento sobre ele” (ibid., p. 260) - uma interpretação que, em especial no caso de Lukács, foi posteriormente abandonada.

Skordoulis (ibid., p.264) fundamenta sua tese de que Marx poderia ser considerado um realista científico com base em considerações na obra do filósofo: 
Marx é um realista científico que sustenta que a ciência tem como objetivo nos dar conhecimento da estrutura subjacente de um mundo material que existe independentemente de nós. Embora reconhecendo que "a experiência sensorial deve ser a base de toda a ciência" (Marx, 1844/1977, p. 94), Marx rejeita a visão empirista de que a ciência está amplamente preocupada em sistematizar o que é diretamente observável e não em descobrir causas subjacentes. . (...) Em O capital Marx faz a seguinte observação: "toda a ciência seria supérflua se a aparência exterior e a essência das coisas coincidirem diretamente" (Marx, 1859/1967, Vol.3, p.817). A primeira de suas Teses sobre Feuerbach, ele considera óbvio que existem "objetos sensuais, realmente distintos dos objetos de pensamento" (Marx, 1845/1970), de modo que "a prioridade da natureza externa permanece inatacável" (Marx e Engels 1845-46 / 1970), e ele critica as visões dos jovens hegelianos na década de 1840 comparando-as com o que ele considera ser uma visão absurda de que o mundo é construído pela consciência.

Skourdolis considera também outra evidência do caráter realista científico em Marx a sua simpatia pela obra A origem das espécies de Darwin, a qual "forneceria nas ciências naturais uma base para a luta de classes histórica” (apud idem) - a dialética entre organismo e sistema, utilizada por Levins e Lewontin (2009), seria um aspecto central tanto para o materialismo dialético como para a teoria da evolução. Este ponto de vista que é concordante ao de Saviani (2012) - sugere que o RS (em especial o RSE) e o neomarxismo de Apple podem ser 'aproximados'. Os conflitos entre eles não precisam ser necessariamente interpretados negativamente, uma vez que eles podem ser justamente o motor de discussões e propostas críticas - isto é, são candidatos a pares dialéticos 'preto-branco' (Robilotta 1988).

Outra tensão, relacionada ao ponto anterior, emerge da suposta proximidade da nova fase de Young a pedagogias tradicionais em oposição à pedagogia crítica defendida por Apple. Com efeito, por exemplo, podem-se notar muitas semelhanças entre a abordagem realista social de Young e algumas diretivas da chamada pedagogia crítica-social dos conteúdos (ver Saviani \& Duarte 2012). Seus propositores defendem que a centralidade sobre os conteúdos na escola "deve garantir esquemas conceituais que permitam ampliar seu universo para além do cotidiano imediato e prover os alunos de capacidade crítica sobre esse mesmo cotidiano” (Lopes \& Macedo 2011, p.88). Os conteúdos, no caso, seriam os chamados 'conhecimentos clássicos' ${ }^{113}$, e, numa forte inspiração gramsciana,

${ }^{113}$ Para Saviani e Duarte, conhecimento clássico: “(...)é aquilo que resistiu ao tempo, tendo uma validade que extrapola o momento em que foi formulado. Define-se, pois, pelas noções de permanência e referência. Uma vez que, mesmo nascendo em determinadas conjunturas históricas, capta questões 
defendem que as classes subalternas precisam se apropria-lo e utilizá-lo como instrumento de luta rumo à revolução social. A noção de conhecimento e historicidade é baseada no que Saviani e Duarte (idem) chamam de Novo Realismo, guiado por um conceito materialista dialético de objetividade - ponto no qual a proximidade com o RS de Young e outros é ainda mais acentuada. Sucede que a pedagogia crítica-social dos conteúdos é muitas vezes criticada por reduzir-se a uma pedagógica tradicional dos conteúdos (ver Silva 2005) - e, 'por arrasto', a nova fase de Young também o faria, por mais que este se esforce em diferenciar-se das tradições neoconservadoras e técnicoinstrumentalistas de currículo. Contudo, Apple (2009, p.248), também inspirado por Gramsci, lembra-nos que, mesmo dentro da pedagogia crítica não devemos cometer ‘suicídio intelectual' - outro gesto que esclarece sua distância ao relativismo de algumas teorias pós-críticas de currículo:

\begin{abstract}
Uma coisa que não devemos fazer é automaticamente assumir que devemos desaprender tudo o que sabemos. Quando Gramsci (...) argumentou que uma das tarefas de uma educação verdadeiramente contra-hegemônica não era jogar fora o "conhecimento da elite", mas reconstruir sua forma e conteúdo para que atendesse a necessidades sociais genuinamente progressistas, ele forneceu a chave para outro papel 'intelectuais orgânicos' pode jogar (...). Assim, não devemos nos envolver em um processo do que poderíamos chamar de "suicídio intelectual”. Ou seja, há habilidades intelectuais (e pedagógicas) sérias em lidar com as histórias e debates em torno das questões epistemológicas, políticas e educacionais envolvidas na justificação do que conta como conhecimento importante.
\end{abstract}

Assim, compete separar: (i) a defesa daquilo tido como 'conhecimentos importantes' em políticas educacionais e curriculares técnico-instrumentalistas; (ii) a defesa dos ‘conhecimentos da elite’ - ou 'conhecimento dos poderosos', cânones a-históricos tidos como importantes a priori por neoconservadores -, e; (iii) a defesa dos conhecimentos importantes (no sentido de Apple acima) ou poderosos (no sentido de Young) - isto é, aqueles conhecimentos fundados sócio-histórico-epistemologicamente, associados ao apelo (progressista) de justiça social de igualdade de acesso e de possibilidade de

nucleares que dizem respeito à identidade do (...) [humano] como um ser que se desenvolve historicamente, o clássico permanece como referência para as gerações seguintes que se empenham em apropriar-se das objetivações humanas produzidas ao longo do tempo (Saviani \& Duarte 2012, p.31). 
mobilidade social ${ }^{114}$ e epistemológica entre os estudantes (princípio de equidade). A dificuldade na distinção de (ii) e (iii) é o que gera classificações espontâneas de propostas como de Saviani e Libâneo e também a de realistas sociais como 'tradicionais', 'conteudistas' ou 'neoconservadoras'. É tentador afirmar que parte dos que falham nesta distinção são o que Apple (1999, p.15) chama de pós-modernistas reacionários, que também insistem que devemos não mais "falar de sonhos, utopia ou justiça social”. Ao deslocar o papel dos conhecimentos locais para a didática - e não o currículo -, Young e outros realistas sociais estão fazendo algo bastante diferente tanto de políticas neoconservadoras, que apontam para o 'conhecimento legítimo' (como a priori, ahistórico) e desprezam os ‘conhecimentos locais’ (Apple 2011, p.28), como das técnicoinstrumentalistas, que numa retórica progressista por vezes até elegem conhecimentos locais, mas sem desviar da visão economicista-mercadológica de educação (Apple 1993, p.314). Realistas sociais insistem que eles têm papel na didática, e não no currículo, como facilitadores no processo de aprendizagem dos conhecimentos poderosos. Young (Galian \& Louzano 2014) usa o exemplo da língua inglesa em ex-(neo)colônias inglesas na África - para ele, nestes lugares, hoje o inglês é indiscutivelmente um conhecimento poderoso. Isso, contudo, não necessariamente implica que línguas e dialetos locais também não o sejam - de fato, o são, e ainda, são também ferramentas didáticas indispensáveis para a aprendizagem de línguas estrangeiras ${ }^{115}$.

\footnotetext{
${ }^{114}$ Talvez seja preciso - e importante - distinguir o nosso apelo pela possibilidade de mobilidade social de apelos com rótulos semelhantes visando direcionar os fins da educação para o mercado de trabalho e a ‘princípios’ de eficiência, competitividade, entre outros. Por um lado, é claro que numa educação deste último tipo também existe concretamente possibilidades de mobilidade social para os estudantes - seguir os balizadores neoliberais pode levar mesmo estudantes de baixa renda a cargos empresariais altíssimos, contrariando as estatísticas (e, eventualmente, compondo argumentos pró 'resiliência' e meritocracia fundados em exceções estatísticas). O problema, simplesmente, é o custo que este tipo de mobilidade social implica - o uso instrumentalista do conhecimento e, pior, a preservação de uma sociedade desigual moldada nas ideologias neoliberal e meritocracia individualista. Assim, em certo sentido, o princípio de equidade é necessariamente ortogonal às hegemonias ideológicas e à globalização do capitalismo neoliberal, por estas exigirem, em seu âmago, o exercício de ocultamento das inequidades sociais que elas causam ou reforçam.

${ }^{115}$ Tampouco significa uma postura de submissão frente às opressões históricas decorridas do colonialismo e neocolonialismo. A presença da língua inglesa em ex-colônias africanas é, sim, por um lado, um resquício de horrores dos processos de colonização - que não devem ser esquecidos nas históricas regionais e macro-histórias. Por outro lado, ela, hoje, dá acesso a um mundo inacessível pelas línguas locais (ainda que, de certa forma, culturas locais também sejam inacessíveis pela língua inglesa), e permite ir além de seus contextos locais - tal como é bastante perceptível hoje no meio acadêmico. De certa forma, a língua inglesa caminha para se tornar uma 'língua global' segundo o linguista David Crystal (2003) - a despeito das positividades e negatividades deste fenômeno, de suas origens imperialistas e de seu preço em termos de opressão e dominação. Com efeito, a justificação do crescimento do uso da língua inglesa no último meio século tem a ver com a força sócio-econômica-militar de potências anglófonas (em especial, naturalmente, os Estados Unidos), e absolutamente nada com suas (supostas) superioridades estéticas e simplicidades gramaticais (Crystal 2003, p.7) - o maior contraexemplo disso é o Latim no fim da Idade Antiga e em boa parte da Idade Média, língua bastante complexa, cuja hegemonia explica-se pelo poder do Império Romano e depois da Igreja Católica na Europa ocidental. Diferentemente de ciências como, por
} 
Uma aparente tensão política aguda entre Apple e Young - no que compete à proximidade ou não a formas atuais de progressivismo educacional -, se desfaz ao notarse que ambos são (em diferentes graus) críticos àquelas influenciadas pelo pósmodernismo. Au e Apple (2009, p.91) sublinham que embora tradições pós-modernas e pós-estruturais tenham apontado para questões importantíssimas - entre elas as conexões entre poder e saber, o foco sobre a multiplicidade e heterogeneidade, a noção de sujeito descentrado -, em sua visão elas não podem substituir as análises estruturais e materialistas características da tradição crítica. O fato, exemplificam os autores, do conceito de classe ser insuficiente para entendermos e agirmos sobre o mundo social não significa que precisamos negligenciá-lo por completo - ao faze-lo, o pós-modernismo acaba por jogar fora o bebê com a água suja (ibid., p.92). Por outro lado, embora preocupado com os interesses das classes subalternas e identitárias em políticas educacionais e currículos, Apple em diferentes momentos mostrou-se apreensivo às contradições de políticas de identidade estadunidenses - as quais, não raro, se acobertam de retóricas progressistas e encontram apoio em discursos pós-modernistas. Au e Apple (2009, p.87) exemplificam com os apelos de equidade (no sentido liberal) por setores conservadores da direita estadunidense, os quais ganham apoio de comunidades oprimidas para políticas altamente mercantilizantes como o sistema de vouchers. Este e outros fenômenos do progressivismo neoliberal (ver Fraser 2017), como o financiamento e visibilidade de fundações neoliberais e neoconservadoras fornecidas a minorias, geram preocupações em Apple (2005, p.73) que não parecem ser tão diferentes daquelas de Young e outros realistas sociais quanto a políticas curriculares localistas. Estas, como já argumentado, flertam com o relativismo epistêmico pós-moderno, enfatizando o subjetivismo e a 'fragmentação' (no sentido de falta de objetividade e conexidade) dos conhecimentos. Partindo da constatação que o denominador comum das políticas pósmodernas, segundo Grant (2011a, p.27), é de que “não há unidade, apenas diferenças”, e

exemplo, a química, a língua inglesa não goza de valor 'epistemológico’, e seu caráter de 'poderosa' resume-se a questões circunstâncias históricas. Com efeito, a questão é que ‘variantes’ da língua inglesa que originam fenômenos tais como os chamados ‘brazinglish' e ‘spanglish' -, praticadas em países onde ela não é a 'primeira língua’, estão hoje tão comuns quanto os ‘cânones’ estadunidense e britânico. Enquanto língua global, o inglês está deixando de ter 'donos' - os falantes nativos -, ainda que estes tenham a vantagem de tê-la enquanto língua materna (idem). Em suma, pode-se tornar mais claro porque a língua inglesa ser um conhecimento poderoso, por exemplo, também no Brasil, segundo o raciocínio de Young (Galian \& Louzano 2014). Por estar em processo de tornar-se uma língua global, e seu domínio pode dar acesso a universos literários e comunicativos complementares àqueles propiciados pela língua portuguesa (a qual também é um conhecimento poderoso) - por exemplo, em materiais não traduzidos, no intercâmbio e diálogo com outras pessoas ou instituições cuja língua materna também não é o inglês. Naturalmente, a questão é polêmica, e não deixará de sê-la enquanto houver associações fortes entre prática mundial de língua inglesa e imperialismo - o que, em certa parte, existe, mas não de forma unânime (ver Crystal 2003). 
considerando, com Carlson e Apple (2003, p.49), que a ênfase na desunidade "é também compatível com a lógica do capital disperso, transnacional” - ao contrário de uma ênfase na unidade descentrada defendida por Apple (1999, p.16) -, não causa espanto que elas sejam alvo de críticas pelos autores, ainda que por diferentes motivos. Paralelamente, não raro parte de contribuições do pós-modernismo servem mais como fonte de desconforto improdutivo do que de apoio às pautas de tradições críticas, como declara Carlson e Apple (ibid., p.15):

(...) há também partes significativas das abordagens pós-modernas tal como elas têm sido incorporadas na educação, que são para nós profundamente irritantes devido à sua arrogância de estilo, à estereotipização de outras abordagens, à certeza de possuírem "novas" respostas, à sua cínica ausência de vínculo com a ação séria em escolas reais, à aparente assertiva de que qualquer enfoque sério na economia deve ser, de algum modo, reducionista, à sua confusão conceitual e, finalmente, à sua retórica tendenciosa que, quando descarregada, comumente diz coisas de absoluto senso comum e que os/as docentes dotados de reflexão crítica já conhecem e vêm fazendo há anos.

Ou, servem tão somente para eternizar o capitalismo, nas palavras de Mészáros (2005, p. 62-3):

A recusa reformista em abordar as contradições do sistema existente, em nome de uma presumida legitimidade do lidar apenas com as manifestações particulares - ou, nas suas variações ‘pós-modernas', a rejeição apriorística das chamadas grandes narratives em nome de petits récits idealizados arbitrariamente - é na realidade apenas uma forma peculiar de rejeitar, sem uma análise adequada, a possibilidade de se ter qualquer sistema rival, e uma formal igualmente apriorística de eternizar o sistema capitalista.

Por outro lado, Apple (2000, p.xxv) concorda com Young (2016b, p.11) sobre a possibilidade de políticas não-progressistas - nas classificações de Young, neoconservadoras ou técnico-instrumentalistas - levarem eventualmente a caminhos progressistas, ainda que estreitos e perigosos. O primeiro menciona exemplos do surgimento de instituições progressistas dentro do contexto estadunidense de mercantilização da educação. O segundo comenta reformas curriculares britânicas sob governos conservadores. O contrário também é válido - ambos alertam concordantemente que mesmo partidos usualmente associados à esquerda eventualmente encabeçam políticas que podem levar a caminhos conservadores, como foi a ocasião do surgimento 
do Novo Partido Trabalhista inglês no fim dos anos 1990s e sua diligência para com avaliações padronizadas e controle de 'gastos' educacionais (Apple 2001, p.117). Por sinal, considerações semelhantes podem ser feitas no contexto educacional brasileiro, como sugerem Accioly, Gawryszewski e Nascimento (2016, p.23) com base na proposta neoliberal-desenvolvimentista do Partido dos Trabalhadores já em seu primeiro mandato presidencial.

O papel do conhecimento - de qual conhecimento - no currículo é talvez uma tensão mais séria entre as propostas de Apple (da nova fase) de Young, e está inevitavelmente relacionada às tensões apresentadas anteriormente. Ela reflete o núcleo das disputas entre diferentes tradições em teorias de currículo, e não poderia ser exaurida neste trabalho. Apple é lembrado por sua luta pelo reconhecimento do conhecimento dos subalternos e de questões multiculturais de identidade, raça e cultura nos debates sobre currículo desafiando, de certa forma, as bases epistemológicas cristalizadas das disciplinas escolares tradicionais (Buras \& Apple 2008, p.24). Isso o coloca explicitamente em oposição a políticas e ideologias neoconservadoras e sua tradição seletiva curricular que apresenta ‘A tradição' e 'O passado significativo' (de ser ensinado hoje), a qual reserva (quando o faz) pouquíssimo espaço no currículo e em livros didáticos ao 'passados insignificantes' - isto é, de grupos marginalizados (Carlson \& Apple 2003, p.37). Isto é, a mensagem de Apple é "incluir vozes de grupos marginalizados" e "ver o mundo pelos olhos daqueles que estão à margem" (idem). Especificamente no contexto estadunidense, isso significa, por exemplo, conforme expressam Buras e Apple (2008, p.29) sobre obras de Dolores Bernal:

(...) [defender] a relevância epistemológica da subjetividade e das intuições culturais dos estudantes de cor nas escolas. Ela demonstrou como as perspectivas feministas chicanas e as eurocêntricas levam a interpretações divergentes da cultura e do conhecimento dos estudantes. Com base no privilégio branco, nos privilégios do inglês, no capitalismo e nas teorias 'científicas’ da inteligência, ela afirma que, por gerações, uma orientação epistemológica eurocêntrica posicionou as chicanas 'como culturalmente deficientes' e caracterizou-os como 'ignorantes, atrasados, sujos, sem ambição e anormais’ (...). Em comparação a isso, uma perspectiva feminista chicana coloca em foco o fato de que um valioso 'conhecimento comunitário e familiar é ensinado para os jovens por meio de lendas, corridos e histórias', uma forma de conhecimento que geralmente é invisível na epistemologia eurocêntrica (...). Delgado Bernal enfatiza que ‘aprender a ouvir essas histórias dentro do sistema 
educacional pode ser uma importante prática pedagógica para professores e estudantes’, a qual expõe uma perspectiva ‘não-majoritária’ que os estudantes em situação mais vantajosa geralmente não estão acostumados a ouvir .

Sucede, todavia, que pelo menos neste exemplo específico as teses de Apple e Young não são necessariamente ortogonais. Primeiro, deve-se levar em conta que a 'conclusão científica’ acerca da suposta inferioridade étnica de algum grupo reflete, na verdade, uma ideologia cientificista-positivista que prega a si aprioristicamente autoridade e objetividade, com força de imposição de discursos de normatividade. Conforme apontamos no primeiro argumento, este é um inimigo a se combater na educação e no EC, e não devemos confundir isto com o valor sócio-histórico da ciência, que é um dos pontos que Young e outros realistas sociais insistem em sublinhar. Em segundo lugar, o ‘conhecimento comunitário e familiar’ é, como enfatizado também por Rata (2012), fundamental para os grupos locais e suas identidades culturais, e eles não podem ser realmente negligenciados no processo de aprendizagem dos conhecimentos poderosos os quais, em seus contextos de origem, eram de fato majoritariamente eurocêntricos, porém hoje são praticados em todo mundo. Por um lado, enquanto à 'epistemologia eurocêntrica’ os conhecimentos locais são invisíveis, tem-se que o oposto também é verdade - para as 'epistemologias locais’ a 'epistemologia eurocêntrica' tende a ser invisível ou sem sentido -, o que é igualmente preocupante. Por fim, o terceiro ponto é que dificilmente realistas sociais discordariam que conhecimentos locais são potencialmente “uma importante prática pedagógica para professores e estudantes”, em especial do ponto de vista didático.

Essa concordância pontual interpretativa não deve esconder a grande gama de discordância entre os autores. Apple não se arrisca, como Young (2016b, p.14) o faz atualmente, em elencar 'conhecimentos melhores' que outros, muito embora não negue a importância da ciência. Nesta questão específica, a obra de Apple abre mais perspectivas a trabalhos que aproximam a tradição crítica da pós-crítica - como faz Paraskeva (2011, p.152), fortemente influenciado pelo autor, argumentando pela 'diversidade epistemológica’ e contra o ‘epistemicídio’ de conhecimentos locais por ‘epistemologias opressoras' - do que caminhos à (re) fundamentação histórica-social-filosófica da ciência.

Uma importante ponderação a se fazer à abordagem de Young e outros realistas sociais reflete o fato de não ser suficientemente claro em seus discursos e teses como supostamente pode-se garantir concretamente o acesso aos conhecimentos poderosos 
para os estudantes de todas as camadas sociais - isto é, que tipos de políticas ou medidas governamentais podem caminhar nesta direção. Tampouco há esclarecimentos mais diretivos de como tal garantia de acesso pode ser entendido plenamente como justiça social’ sem levar em conta condições materiais, culturais e econômicas, para que então os estudantes - especialmente de classes mais frágeis - possam também gozar ou aproveitar apropriadamente de tal acesso. Com efeito, há gritantes evidências de que, além de garantir os conhecimentos poderosos nos currículos, é preciso garantir 'condições poderosas’ nas infraestruturas sociais e escolares - em especial no ensino básico -, assim como 'metodologias e didáticas poderosas' no sentido de conferir aos estudantes o poder de se apropriar dos conhecimentos e metaconhecimentos poderosos (Venville, Rennie \& Wallace 2012, p.747). Estes são terrenos carentes de extensa análise e intenso trabalho. Substancialmente, no caso brasileiro, todo esforço de realistas sociais vai por água abaixo se também não lutarmos por 'condições poderosas', por possibilidades de mudança de um:

(...) sistema educacional excludente, sem nenhum compromisso com os ideais igualitários e republicanos, de baixa qualidade, insuficiente, muito aquém daquilo que poderíamos ter, desrespeitando professores e estudantes. Evidentemente, suas consequências são e serão terríveis: reproduzimos as desigualdades, não formamos os quadros de que o país tanto precisa, não damos a todos as mesmas oportunidades de se desenvolverem como pessoas e marginalizamos enormes contingentes populacionais (Helene 2013, p.135).

Tal possibilidade de mudança não é, de longe, uma tarefa fácil ou trivial, como é bem sabido. Ela passa, entre outros pontos, pela adequação estrutural escolar - por exemplo, com laboratórios didáticos, bibliotecas -, valorização da carreira docente, adoção de políticas de gratuidade ativa - compensando despesas com transporte, alimentação, materiais escolares e outros para famílias mais economicamente frágeis -, eliminação imediata dos processos de mercantilização e privatização da educação e universalização da educação pública em todos os níveis (ibid., p.140). As chances de um processo de transformação lento e gradual, porém, são ameaçadas pela volatilidade governamentalpartidária - isto é, a mudança de governos e a consequente mudança de políticas num espaço de tempo relativamente curto -, por interesses de grupos poderosos, a manutenção contínua de hegemonias ideológicas, pelo pessimismo e relativismo pós-modernos e também pela desmobilização política (muitas vezes involuntária) daqueles e daquelas 
comprometidos com valores de justiça social. Enquanto, por um lado, temos um conhecimento razoável de parte dos problemas educacionais brasileiros (ibid., p.141), não temos tempo ou fôlego para esperar alcançarem-se as ‘condições poderosas’ para só então concentrarmos esforços para o acesso de conhecimentos e metaconhecimentos poderosos na educação básica e superior. É justamente a necessária concomitância destas lutas pelas condições de acesso e pelo acesso em si - que desloca a HFC no EC do conforto da parcimônia e leva-a também à luta. E, por sua vez, é também por isso que argumentamos que um papel fundamental da HC no EC é lutar justamente contra a ideologia cientificista-positivista que desistoriza a ciência, e que um papel fundamental da FC no EC é lutar contra a ideologia relativista pós-moderna que esvazia seus valores sociais e objetivos, e que estas lutas não estão desvencilhadas daquelas contra os processos de mercantilização da educação e por valores de justiça social e equidade sócio-educacional.

O conjunto de tensões e ponderações comentado anteriormente - insipiente de um possível espectro maior de tensões e ponderações ainda por revelar-se - reflete-se, de uma forma ou de outra, nos próprios argumentos. Isto é, nossos dois argumentos são necessariamente instáveis e não 'casam' completamente entre si - e, tampouco são eles, sozinhos, mais sólidos. É possível que, caso fossem compatíveis, sua força conjunta seria desinteressante. Os conflitos que suscitam não são apenas inevitáveis - mas imprescindíveis.

\subsection{Da sincera incompletude desta tese}

Esta tese pode, aparentemente com certa justiça, ser acusada de 'mais abrir portas do que fechar', ou 'mais criar problemas do que resolver'. Da vista do nosso ponto, contudo, entendemos que entreabrimos portas importantes, relativamente esquecidas ou despercebidas por nossos pares. Há muito ainda que se fazer - além de tais importantes portas há universos novos, complexos e intrincados a serem investigados, e que podem fornecer 'respostas circunstanciais' valiosas a secções de problemas urgentes. Nesta tese não fomos capaz de darmos estas 'respostas' pois ela é 'incompleta'. Parte da incompletude desta tese se reflete em sua incapacidade de 'movimento'.

Por outro lado, sua incompletude é, também, voluntária e desejada. Numa analogia, podemos associar a suposta completude de uma tese à acepção tradicional de teoria - com suas 'hipóteses', 'desenvolvimento’ e ‘conclusões', autocontidas, com metodologias 
independentes do objeto, conclusões a-históricas e descontextualizadas -, e a incompletude de uma tese à acepção crítica de teoria - no qual há interações dialéticas entre 'objetos', 'metodologias' e ‘conclusões'. De ato, atacamos problemas neste trabalho que não são exatamente fixos - ainda que insistamos em usar continuamente alguns mesmos rótulos -, e eles embaralham nossos 'objetos', 'metodologias' e 'conclusões'. Para que esta tese em questão fosse 'completa', seria preciso, de alguma forma, que ela acompanhasse e perseguisse a dinâmica dos problemas visados, os quais estão sempre em movimento. Porém, essa tese, por si só, não pode 'se mover' - e por isso, não pode por si só alcançar plenamente os problemas atacados. É por isso que ela não pode almejar tal completude. E, com efeito, também não desejamos que ela o tenha - isso significaria aceitarmos a ilusão de que vivemos em um mundo onde os problemas são simples, sempre os mesmos, o que é uma saída tipicamente ideológica (no sentido discutido no segundo capítulo). E isto, como procuramos enfatizar ao longo deste trabalho, não nos interessa, por mais que seja psicologicamente confortável ou conceitualmente sedutor. Dito em outras palavras, uma 'tese completa' destruiria a si mesma, tornaria uma carga de esforço físico e mental enorme em algo de pouco valor prático para lidar com questões urgentes.

'Teses completas' são 'amoladores de faca', no sentido atribuído pelo psicólogo brasileiro Luís Antônio Baptista (1999) (ainda que num sentido diverso do qual agora usaremos). ‘Amoladores de facas’ são existências que gozam de prestígio, de voz ouvida, e que acabam por extravasar enunciados 'completos' (ideológicos) com as quais, embora não matem, amolem a faca para que terceiros o façam - o que é especialmente grave no caso de teses elaboradas em universidades públicas, que gozam de prestígio e reconhecimento. 'Teses completas' enunciam que 'o problema’ ‘é’ A, e que ‘a solução' 'é' 'sempre’ B - sendo que ‘o problema’ é algo em movimento, ele está-sendo, e não ‘é' apenas 'A', da mesma forma que não há solução 'para sempre', e sim um luta e esforços contínuos definindo e redefinindo tanto os 'problemas' como as 'soluções'. E elas desviam a atenção da natureza estrutural dos problemas, e, portanto, tais teses entram no hall de amoladores de faca - ainda que bem intencionadas -, cujo tipo de discurso, prestigiado e legitimado, serve de molde para políticas educacionais neoliberais e reformas empresariais. Estas, enunciam que 'o problema' 'é' C (por exemplo, 'o problema das instituições públicas é a má gestão’) e que ‘solução’ ‘é naturalmente’ D (por exemplo, 'privatização'). Eis a facada, com o fio cortante acidentalmente (ou não) alinhado. 
No sentido acima, entendemos, portanto, que a função de uma tese - na nossa área de pesquisa, enfatiza-se - não é ‘tornar-se supérflua’ (isto é, no sentido de o que uma ‘tese completa' se torna depois de 'resolver os problemas a que se propõe’). Numa leitura de um trecho poético de Mario Quintana, a função de fazer uma tese é 'dar corda ao relógio do mundo' - isto é, e aqui entra a leitura propriamente dita, manter o 'relógio' funcionando, para que então outro 'fazer de tese', logo em seguida, dê mais um pouco de corda, e assim por diante. Em outras palavras, embora uma tese sozinha não consiga 'se movimentar', ela pode abrir uma porta para que outra tese no futuro inicie a explorar - e ainda outro, mais no futuro, explore um pouco mais, e assim sucessivamente. O ‘movimento’ está no conjunto, na cooperação, no trabalho paciente do passo-a-passo de cada tese-a-tese, na continuidade, na persistência coletiva no tempo frente à finitude inevitável do tempo individual - como eventos que se dão as mãos para compor uma linha de mundo no espaço-tempo. Em suma, a função desta tese é, realmente, a de 'mais abrir portas do que fechar' - em cada leitura, mais ou menos atenta, integral ou parcial, um cone de luz se abrirá, oferecendo um futuro de possibilidades de ir além.

Concluímos este trabalho com esperança de que ele tem potencial de fornecer subsídios àqueles tão preocupados quanto nós acerca das problemáticas levantadas. Nossos diagnósticos, considerações teóricas e também nossos dois argumentos, longe de definitivos, hão de trazer mais inquietações e análises, mesmo em nossos próprios trabalhos futuros - e, quiçá, originarão outros trabalhos, 'dando corda no relógio do mundo', e mantendo viva a defesa de valores de justiça social e a resistência contra mecanismos de preservação e intensificação das desigualdades sociais. 


\section{Referências bibliográficas}

Abbeele, Georges Van Den (2011). Postmodernism and critical theory. In: Sam, S. (ed.): The Routledge Companion to Postmodernism. Londres e Nova Yorque: Routledge Taylor \& Francis Group, 15-25.

Abd-El-Khalick, Fouad (2014). The evolving landscape related to assessment of nature of science. In: Lederman, Norman \& Abell, S. (eds.): Handbook of research on science education. Vol. II. Nova Yorque: Routledge, 621-650.

Abd-EI-Khalick, F. (2012). Examining the Sources for our Understandings about Science: Enduring conflations and critical issues in research on nature of science in science education. International Journal of Science Education, 34(3), 353-374.

Abd-El-Khalick, Fouad \& Lederman, Norman (2000). Improving science teacher's conceptions of nature of science: a critical review of literature. International Journal of Science Education, vol. 22 (1), 665-701.

Ação Educativa (2016). A ideologia do movimento escola sem partida: 20 autores desmontam o discurso. Ação Educativa Assessoria, Pesquisa e Informação (Org.). São Paulo: Ação Educativa.

Accioly, Inny; Gawryszewski, Bruno \& Nascimento, Luciane (2016). Commodifying education in a dependent capitalist country. In: Leher, Roberto \& Accioly, Inny (orgs.): Commodifying Education Theoretical and Methodological Aspects of Financialization of Education Policies in Brazil. Rotterdam: Sense Publishers.

Aduriz-Bravo, A. (2007). A proposal to teach the nature of science (NOS) to science teachers: The 'structuring theoretical fields' of NOS. Review of science, mathematics and ICT education, 1(2), 41-56.

Aikenhead, Glen S. (2006). Science Education for Everyday Life. New York and London: Teachers College Press.

Allchin, Douglas (2013). Teaching Nature of Science. Perspectives \& Resources. Saint Paul: SHiPS Education Press.

(2011). Evaluating knowledge of the nature of (whole) science. Science Education, 95(3), 518-542

(2004). Pseudohistory and Pseudoscience. Science Education, 13, 179-195 
(2004b). Should the Sociology of Science be rated X? Science Education, 88(6), 934-946.

(2003). Lawson's Shoehorn, or Should the Philosophy of Science Be Rated X? Science \& Education, 12(3), 315-329.

Alters, B. J. (1997a). Nature of science: A diversity or uniformity of ideas? Journal of Research in Science Teaching, 34 (10), 11 05-1108.

(1997b). Whose nature of science? Journal of Research in Science Teaching, 34(1), 39-55.

Althusser, Louis (1984). Essays on Ideology. London: Verso.

Apple, Michael (1971). The hidden curriculum and the nature of the conflict. Interchange, 2(4), 27-40.

(1989). Educação e poder. Trad. Maria Cristina Monteiro. Porto Alegre: Artmed.

(1993). What Post-modernists forget: cultural capital and official knowledge. Curriculum Studies, 1(3), 301-316.

(1999). Freire, neo-liberalism and education. Discourse: studies in the cultural politics of education, 20(1), 5-21.

(2000). Official Knowledge: democratic education in a conservative age. $2^{\text {nd }}$ ed. New York: Routledge

(2001). Creating profits by creating failures: standards, markets, and inequality in education. International Journal of Inclusive Education, 5(2-3), 103-118. (2004). Ideology and Curriculum. 3rd ed. New York: Routledge.

(2006). Educating the 'Right Way': Markets, Standards, God, and Inequality. $2^{\text {nd }}$ ed. New York, London: Routledge

(2005). Para além da lógica do mercado: compreendendo e opondo-se ao neoliberalismo. Trad. Gilka Garcia e Luciana Ache. Rio de Janeiro: DP\&A.

(2009). Can critical education interrupt the right? Discourse: Studies in the Cultural Politics of Education, 30(3), 239-251.

(2011). Democratic education in neoliberal and neoconservative times. International Studies in Sociology of Education, 21(1), 21-31.

(2013). Can Education Change Society? Nova Yorque e Londres: Routledge. (2016). What is Present and Absent in Critical Analyses of Neoliberalism in Education. Peabody Journal of Education, 0, 1-6. 
Apple, Michael \& Buras, Kristen (2008). Respondendo ao conhecimento oficial. In: Apple, Michael \& Buras, Kristen e col.: Currículo, poder e lutas educacionais, com a palavra, os subalternos. Trad. Ronaldo Catado Costa. Porto Alegre: Artmed, 273-285.

Arendt, Hannah (1992). Entre o passado e o futuro. Trad. Mauro W. Barbosa. São Paulo: Perspectiva.

Aronowitz, S. \& Giroux, H. (1991). Postmodern education: politics, culture, social criticism. Minneapolis-London: University of Minnesota Press.

Arroyo, M. G. (1999). Experiências de inovação educativa: o currículo na prática da escola. In: Moreira, Antônio F. (org.): Currículo: políticas e práticas. Campinas, São Paulo: Papirus, 133-164.

Asimov, Isaac (1989). The relativity of wrong. The Skeptical Inquirer, 14(1), 35-44.

Au, Wayne (2009). Standardizing Inequality: The Hidden Curriculum of High-Stakes Testing. In: Au, Wayne: Unequal by Design: High-Stakes Testing and the Standardization of Inequality. Nova Yorque e Londres: Routledge, 137-146

(2011). Teaching under the new Taylorism: high-stakes testing and the standardization of the 21st century curriculum. Journal of Curriculum Studies, 43(1), 2545.

(2013). Hiding behind high-stakes testing: Meritocracy, objectivity and inequality in U.S. education. The International Education Journal: Comparative Perspectives, 12(2), 7-19.

Au, Wayne \& Apple, Michael (2009). Rethinking reproduction, neo-marxism in critical education theory. In: Apple, Michael.; Au, Wayne \& Gandin, Luis A.: The Routledge International Handbook of Critical Education. Nova Yorque e Londres: Routledge, 83-95.

Ávila, Gabriel (2013). Epistemologia em conflito. Col. Scientia. Belo Horizonte: Fino Traço.

Bagdonas, Alexandre \& Silva, Cibelle, C. (2013) Controvérsias sobre a natureza da ciência na educação científica. In: Silva, Cibelle \& Prestes, Maria Elice (org.).: Aprendendo ciência e sobre sua natureza: abordagens históricas e filosóficas. São Carlos: Tipografia, 209-218.

Bagdonas, Alexandre; Fabrício, Vitor; Gurgel, Ivã; Noronha, André \& Velasquez, Felipe (2017). A didactic game about cosmology designed to tackle controversies about science. In: Pietrocola; Maurício \& Gurgel, Ivã (org.): Crossing the Border of 
Traditional Science Curriculum: innovative teaching and learning in Science Basic Education. Boston: Sense Publishers, 163-179.

Bagdonas, Alexandre; Rozentalski, Evandro \& Polati, Flávia (2015). Controversial aspects of the construct NOS in the Ibero-American Science Education journals: a literature review. Proceedings of 13th Biennial International Conference of International History and Philosophy of Science Teaching Group, CEFET, Rio de Janeiro, Brasil.

Ball, Stephen (2004). Education for Sale! The commodification of Everything? King's Annual Education Lecture. University of London. Disponível em http://www.asu.edu/educ/epsl/CERU/articles/CERU-0410-253-OWI.pdf, acessado setembro de 2017.

Banfield, Grant (2015). Critical realism for marxist sociology of education. Nova Yorque: Routledge.

Baptista, Luis Antonio (1999). A atriz, o padre e a psicanalista - os amoladores de faca. In: Baptista, Luis Antonio: A cidade dos sábios. São Paulo: Summus, 45-49

Barra, Eduardo Salles (1998). A realidade do mundo da ciência: um desafio para a história, a filosofia e a educação científica. Ciência \& Educação, 5(1), 15-26.

Bauer, Adriana (2010). Usos dos resultados das avaliações de sistemas educacionais: iniciativas em curso em alguns países da América. Revista Brasileira de Estudos Pedagógicos, 91 (228), 315-344.

Bauer, Adriana; Alavarse, Ocimar \& Portela, Romualdo (2015). Avaliações em larga escala: uma sistematização do debate. Educação e Pesquisa, 41, 1367-1382.

Bauman, Zygmunt (2005). Education in Liquid Modernity. The Review of Education, Pedagogy and Cultural Studies, 27(4), 303-317.

Beck, Johan. (2013) Powerful knowledge, esoteric knowledge, curriculum knowledge. Cambridge Journal of Education, 43 (2), 177-193.

Bernal, John D. (1971). Science in History Vol. 2: The scientific and industrial revolution. Cambridge: MIT Press.

Bernstein, Basil (2000a). Thoughts on the Trivium and Quadrivium: The Divorce of Knowledge from the Knower. In: Bernstein, Basil: Pedagogy, Symbolic Control and Identity: Theory, Research, Critique. Rev. ed. Lanhan, Boulder, New York, Oxford: Rowman \& Littlefield Publishers Inc., 81-88.

(2000b). Official Knowledge and Pedagogic Identities: The Politics of Recontextualisation. In: Bernstein, Basil: Pedagogy, Symbolic Control and Identity: 
Theory, Research, Critique. Rev. ed. Lanhan, Boulder, New York, Oxford: Rowman \& Littlefield Publishers Inc., 65-80.

(2000c). Vertical and Horizontal Discourse: An Essay. In: Bernstein, Basil: Pedagogy, Symbolic Control and Identity: Theory, Research, Critique. Rev. ed. Lanhan, Boulder, New York, Oxford: Rowman \& Littlefield Publishers Inc.,155-174. (2003). Class, codes and control, volume III: Towards a theory of educational transmission. Londres e Nova Yorque: Routledge.

Brasil, MEC (1996). Lei de Diretrizes e Bases da Educação Nacional: Lei número 9394, 20 de dezembro de 1996, que estabelece as diretrizes e bases da educação nacional.

Brasil, MEC (2013). Diretrizes Curriculares Nacionais da Educação Básica. Brasília: MEC.

(2018). Base Nacional Comum Curricular: Ensino Médio. Terceira versão.

Brasília: MEC. Disponível em: http://basenacionalcomum.mec.gov.br/wpcontent/uploads/2018/04/BNCC_EnsinoMedio_embaixa_site.pdf, acesso maio de 2018.

Brush, Stephen (1974). Should de History of Science Be Rated X? Science, 183, 11641172.

(1999). Why relativity was accepted? Physics in Perspective, 1, 184-214.

Bosi, Alfredo (2010). Ideologia e contraideologia: temas e variações. São Paulo: Companhia das Letras.

Bourdieu, Pierre (2001). Para uma sociologia da ciência. Trad. Pedro Duarte. Lisboa: Edições 70.

Brush, Stephen G. (1974). Should the History of Science Be Rated X? Science, 183, 1164-72.

Bucher, Geoff (2015). Marxismo. Trad. Noéli Sobrinho. Petrópolis: Vozes.

Buras, Kristen \& Apple, Michael (2008). Introdução. In: Apple, Michael \& Buras, Kristen (org.): Currículo, poder e lutas educacionais, com a palavra, os subalternos. Porto Alegre: Artmed, 9-48.

Burke, Peter (2016). O que é história do conhecimento? Trad. Claudia Freire. São Paulo: Editora Unesp.

Cardoso, Danilo; Noronha, André; Watanabe, Graciela \& Gurgel, Ivã (2015). Texto jornalístico sobre ciência: uma análise do discurso sobre a natureza da ciência. Alexandria Revista de Educação em Ciência e Tecnologia, 8(3), 229-251. 
Carlson, Dennis \& Apple, Michael (2003). Teoria educacional crítica em tempos incertos. In: Hypolito, Álvaro \& Gandin, Luis A. (orgs): Educação em tempos de incertezas. Trad. Helena de Souza. Belo Horizonte: Autêntica, 11-58.

Castañon, Gustavo Arja (2007). Construtivismo, Inatismo e Realismo: compatíveis e complementares. Ciência \& Cognição, 10, 115-131.

Castro, Maria Helena Guimarães de (2009). Sistemas de avaliação da educação no Brasil: avanços e novos desafios. São Paulo em Perspectiva, 23(1), 5-18. 156

(2011). Quem manda na Educação? Interessa Nacional, 4(15), 1-12.

Castro, Maria Helena Guimarães de \& Fini, Maria Inês (2008). Uma renovação curricular muito além do currículo. Cadernos CENPEC, 5, 93-97.

CGEE (Centro de Gestão e Estudos Estratégicos) (2017). A ciência e a tecnologia no olhar dos brasileiros: percepção pública da C\&T no Brasil - 2015. Brasília: CGEE.

Chakravartty, Anjan (2017). Scientific Realism. Stanford Encyclopedia of Philosophy. Disponível em https://plato.stanford.edu/archives/sum2017/entries/scientific-realism/ acesso agosto de 2017.

Charlot, Bernard (2005). Relação com o saber, formação dos professores e globalização.

Trad. Sandra Loguercio. Porto Alegre: Artmed, 2005.

Chauí, Marilena (2003). A universidade pública sob nova perspectiva. Revista Brasileira de Educação, 24, 5-15.

(2008). O que é ideologia? Col. Primeiros Passos. São Paulo: Brasiliense. (2016/1979). Ideologia e educação. Educação e pesquisa, 42(1), 245-257.

(2017). Avaliação irracional da pesquisa e eclipse da docência na USP. Revista ADUSP, 60, 54-65.

Cobern, WilliamW. (1990). Education Research Will Not Profit From Radical Constructivism. Scientific Literacy and Cultural Studies Project. Paper 1. Tradução livre de trechos.

Condé, Mário L. L. (2017). Um papel para a história: o problema da historicidade da ciência. Curitiba: Ed.UFPR.

Connelly, F. M. (1969). Philosophy of science and the science curriculum. Journal of Research in Science Teaching, 6(1), 108-113.

Cruz, F. F. S.; Kawamura, M. R. D.; Abrantes, P. C. C. \& Martins, R. de A. (1988). Mesa-redonda: influência da história da ciência no ensino de física. Caderno Catarinense de Ensino de Física, 5 (número especial), 76-92.

D’Ambrósio, Ubiratan (1998). Etnomatemática. São Paulo: Editora Ática. 
Crystal, David (2003). English as a global language. $2^{\mathrm{a}}$ ed. Cambridge: Cambridge University Press.

Dagher, Zoubeida R. \& Erduran, Sibel (2016). Reconceptualizing the nature of Science for science education. Science \& Education, 25(1), pp.147-164.

de Lucena, Mariana Barrêto N. (2012). Os debates do movimento feminista: do movimento sufragista ao feminismo multicultural. Atas do $17^{\circ}$ Encontro Nacional da Rede Feminista Norte e Nordeste de Estudos e Pesquisa sobre a Mulher e Relações de Gênero. UFPB, Recife, 1-13.

Darrigol, Olivier (2000). Electrodynamics from Ampère to Einstein. Oxford: Oxford University Press, 2000.

(2005). The Genesis of the Relativity Theory. Séminaires Poincaré, vol. I, pp.1-20, 2005.

(2012). Poincaré’s Light. Séminaires Poincaré, vol. XVI, pp. 1-43, 2012.

Daston, Lorraine \& Galison, Peter (2007). Objectivity. Nova Yorque: Zone Books.

Daston, Lorraine (2017). Historicidade e objetividade. Org : Tiago Santos Almeida. Trad: Derley Alves e Francine Iegelski. São Paulo : LiberArs.

Deng, Zongyi (2015). Michael Young, knowledge and curriculum: an international dialogue. Journal of Curriculum Studies, 47(6), 723-732.

Jan Derry (2018): What is educationally worthwhile knowledge? Revisiting the case for powerful knowledge. In: Guile, D.; Lambert, D. \& Reiss, Michael J.: Sociology, Curriculum Studies and Professional Knowledge: New perspectives on the work of Michael Young. London e Nova Yorque: Routledge (E-book ISBN 978-1-315-56041$0), 133-153$.

Désaultels, Jacques (2015). L’ideologie de/dans l'enseignement des sciences. Canadian Journal of Science, Mathematics and Technology Education, 15(4), 344-350.

Doll Jr, William (1993). A post-modern perspective on curriculum. Trad. ???. Nova Yorque: Teacher College Press.

Dutra, Luiz Henrique de A. (2010). Introdução à epistemologia. São Paulo: Editora UNESP.

Duschl, R. A. (1985). Science education and philosophy of science: twenty-five years of mutual exclusive development. School Science and Mathematics, 85(7), 541-554.

Eagleton, Terry (ed.) (2013). Ideology. Londres e Nova Yorque: Routledge.

Eflin, J. T., Glennan, S. \& Reisch, G. (1999). The Nature of Science: A Perspective from the Philosophy of Science. Journal of Research in Science Teaching, 36 (1), 107-116. 
Einstein, Albert (1905). Zur Elektrodynamik bewegter Körper. Annalen der Physik, 17 (10), 891-921.

Fara, Patricia (2014). Uma breve histórica da ciência. Trad. Karin Hueck. São Paulo: Editora Fundamento Educacional Ltda.

Ferreira, Eliza B. (2017). A contrarreforma do ensino médio no contexto da nova ordem e progresso. Educação \& Sociedade, 38(139), 293-308.

Forato, Thaís C. M. (2009). A Natureza da Ciência como Saber Escolar: Um Estudo de Caso a Partir da História da Luz. Tese de Doutorado, Faculdade de Educação da Universidade de São Paulo. São Paulo.

Forato, Thaís \& Guerra, Andreia (2014). Historiadores das ciências e educadores: frutíferas parcerias para um ensino de ciências reflexivo e crítico. Revista Brasileira de Histórica da Ciência, Dossiê História das Ciências e Ensino de Ciências, 7(2), 137141.

Forquin, Jean C. (1992). Saberes escolares, imperativos didáticos e dinâmicas sociais. Teoria \& Educação, 5, 28-49.

Fraser, Nancy (2017). Progressive Neoliberalism versus Reactionary Populism: A choice that feminists should refuse. Nordic Journal of Feminist and Gender Research, 24(4), 281-284.

Freire, Paulo (2011). O cientista em seu devido lugar. In: Freire, Paulo \& Guimarães, Sérgio. Educar com a mídia: novos diálogos sobre educação. São Paulo: Paz e Terra.

Freitas, Luiz Carlos de (2016). Três teses sobre as reformas empresariais da educação: perdendo a ingenuidade. Revista CEDES, 36(99), 137-153.

(2018). A BNCC e a "salvação” dos pobres pela resiliência. Avaliação Educacional - Blog do Freitas. Disponível em: https://avaliacaoeducacional.com/2018/03/08/a-bncc-e-a-salvacao-dos-pobres-pelaresiliencia/, acesso em abril de 2018.

French, Marylin (2008). From Eve to Dawn, a History of Women - Volume 2: The Masculine Mystique. Nova Yorque: The Feminist Press at the City University of New York.

Gadotti, Moacir (2016). A escola cidadã frente ao "escola sem partido". In: Ação Educativa: A ideologia do movimento escola sem partido. São Paulo: Ação Educativa.

Galian, Claudia V. A. \& Louzano, P. B. J. (2014) Michael Young e o campo de currículo: da ênfase no "conhecimento dos poderosos" à defesa do "conhecimento poderoso". Educação e Pesquisa, 40 (4), 1109-1124. 
Galison, Peter (2003). Einstein’s Clocks, Poincaré’s Maps: Empires of Time. New York: WW. Norton \& Company Ltd.

(2008). Ten problems in History and Philosophy of Science. Isis, 99(1), 111124.

Gamble, Andrew (1999). Marxism after Communism: beyond Realism and Historicism. Review of International Studies, 25, 127-144.

Gandin, Luís Armando \& Lima, Iana Gomes de (2016). A perspectiva de Michael Apple para os estudos de políticas educacionais. Educação e Pesquisa, 42(3), 651-664.

Gavroglu, Kostas (2012). Science popularization, hegemonic ideology and commercialized science. Journal of History of Science and Technology, 6, 85-99.

Gil-Pérez, D.; Montoro, I. F.; Alís, J. C.; Cachapúz, A. \& Praia, J. (2001). Para uma imagem não deformada do trabalho científico. Ciência \& Educação, 7(2), 125-153.

Gil-Pérez, Daniel; Guisasola, Jenaro; Moreno, Antonio; Cachapuz, Antonio; Carvalho, Anna Maria P. de; Torregrosa, Joaquín Martínez; Salinas, Julia; Valdés, Pablo; Gonzáles, Eduardo; Duch, Anna Gené; Dumas-Carré, Andrée; Tricárico, Hugo \& Gallego, Rómulo (2002). Defending Constructivism in Science Education. Science \& Education, 11, 557-71. Tradução livre de trechos.

Good, Ronald G.; Wandersee, James H. \& Julien, John St. (1993). Cautionary Notes on the Appeal of The New "Ism" (Constructivism) in Science Education. In: Tobin, Kenneth (ed.) The Practice of Constructivism in Science Education. Hillsdale: Lawrence Erlbaum Associates Publishers, 71-87. Tradução livre de trechos.

Grant, Iain Hamilton (2011a). Postmodernism and politics. In: Sim, S. (ed.): The Routledge Companion to Postmodernism. Londres e Nova Yorque: Routledge Taylor \& Francis Group, 25-36.

(2011b). Postmodernism and science and technology. In: Sam, S. (ed.): The Routledge Companion to Postmodernism. Londres e Nova Yorque: Routledge Taylor \& Francis Group, 94-106.

Greca, I. M., \& Freire Jr., Q. (2004). A "crítica forte" da ciência e implicações para a Educação em Ciências. Ciência \& Educação, 10(3), 343-361.

Grossberg, Lawrence (1986): On Postmodernism and Articulation: An Interview with Stuart Hall. Journal of Communication Inquiry, 10, 45-60.

Guerra, Andrea; Braga, Marco \& Reis, José C. (2007). Teoria da relatividade restrita e geral no programa de mecânica do ensino médio: uma possível abordagem. Revista Brasileira de Ensino de Física, 29(4), 575-583. 
Guile, D.; Lambert, D. \& Reiss, Michael J. (2018). Sociology, Curriculum Studies and Professional Knowledge: New perspectives on the work of Michael Young. Londres e Nova Yorque: Routledge (E-book).

Hacking, I. (2012). Representar e Intervir: tópicos introdutórios de filosofia da ciência natural. Trad. Pedro Rocha de Oliveira. Rio de Janeiro: EDUERJ.

Hall, Stuart (2000). The problem of ideology: Marxism without guarantees. In: Morley, David \& Chen, Kuan-Hsing (ed.): Stuart Hall, Critical dialogues in cultural studies. Londres e Nova Yorque: Routledge, 1-24.

(2011). The Neoliberal revolution. Cultural Studies, 25(6), 705-728.

Halffman, Wilhelm \& Radder, Hans (2017). Manifesto acadêmico: de uma universidade ocupada a uma universidade pública. Trad. Tamires von Atzingen, Carlos Machado e Marcos Barbosa de Oliveira. Revista ADUSP, 60, 6-25.

Hartwell, R. M. (1990). Was there an industrial revolution? Social Science History, 14(4), 567-576.

Heilbron, John L. Was There a Scientific Revolution? In: Buchwald, Jed Z. \& Fox, Robert (eds).: The Oxford Handbook of the History of Physics. Oxford: Oxford University Press, 7-24.

Helene, Otaviano (2013). Um diagnóstico da educação brasileira. Campinas: Autores Associados.

Hellman, Hal (1999). O buldogue de Darwin contra Sam 'Escorregadio': as guerras da evolução. In: Hellman, Hal: Grandes debates da ciência: dez das maiores contendas de todos os tempos. Trad. José Óscar de Almeida Marques. São Paulo: EDUNESP, 111-140.

Hicks, Stephen (2004). Explaining Post-Modernism. Wisconsin, New Berlin: Scholargy Publishing.

Hoadley, Ursula (2015). Michael Young and the curriculum field in South Africa. Journal of Curriculum Studies, 47(6), 733-749.

Höttecke, Dietmar \& Silva, Cibelle C. (2011). Why implementing history and philosophy in school science education is a challenge: an analysis of obstacles. Science \& Education, 20, 293-316.

Hebmüller, Paulo (2016). Secundaristas ocupam escolas e impõem raro revés a governo tucano. Revista ADUSP, 59, 32-40.

Hodson, D. (2014). Nature of Science in the Science Curriculum: Origin, Development, Implications and Shifting Emphases. In: Matthews, M. R. (ed.): International 
handbook of research in history, philosophy and science teaching. Dordrecht: Springer, 911-970.

Irigaray, Luce (1987). Sujet de la science: sujet sexué? In: CNRS: Sens et place des connaissances dans la societé. Vol. III. Paris: Presses du CNRS, 95-122.

Irzik, Gurol \& Nola, Robert (2011). A Family Resemblance Approach to the Nature of Science for Science Education. Science \& Education, 20, pp.591-607.

lrzik, G., \& Nola, R. (2014). New Directions for Nature of Science Research. In: Matthews, M. R. (ed.): International Handbook of Research in History, Philosophy, and Science Teaching. Dordrecht: Springer, 999-1021.

Jameson, Fredric (1996). Pós-modernismo: a lógica cultural do capitalismo tardio. Trad. ???. São Paulo: Ática.

Jammer, Max (2006). Concepts of Simultaneity: from antiquity to Einstein and beyond. Baltimore: The Johns Hopkins University Press.

Jimenez, Emmanuel; King, Elizabeth \& Tan, Jee-Peng (2012). Making the grade. Finance \& Development (Banco Mundial), Março, 12-14.

Karpov, Alexander (2013). The commodification of Education. Russian Social Science Review, 54(5), 22-37.

Kevles, Daniel (2005). Albert Einstein: Relativity, War and Fame. In: Princeton University: A Century of Books: Princeton University Press, 1905-2005. Princeton: Princeton University Press, 115-124.

Kinchloe, Joe \& Tobin, Kenneth (2009). The much exaggerated death of positivism. Cultural Studies in Science Education, 4, 513-528.

Kragh, Helge (1998). Social constructivism, the gospel of science, and the teaching of phyisics. Science \& Education, 7, 231-243.

Krause, Décio (2010). Sobre estruturas e o realismo estrutural: estruturas como representação. ANPOF, 1-14. Disponível em: http://www.cfh.ufsc.br/ dkrause/Artigos/2010/Anpof2010.pdf, acesso maio de 2014.

Kremer, Hugo F. (1967). Fresnel's equation in general relativity. Journal of Mathematical Physics, 8(6), 1197-1199.

Kuhn, Thomas (1997). A Estrutura das Revoluções Científicas. 5a ed. São Paulo: Perspectiva S.A.

Ladyman, James (1998). What is structural realism? Studies in History and Philosophy of Science, 29(3), 409-424. 
(2016): Structural Realism. Stanford Encyclopedia of Philosophy. Disponível em: https://stanford.library.sydney.edu.au/entries/structural-realism/, acesso junho de 2015.

Lakatos, I. (1970). History of Science and its Rational Reconstructions. Proceedings of lhe Biennial Meeting of the Philosophy of Science Association, 91-136.

Lambert, D. (2014). Subject teachers in knowledge-led schools. In: Young, M.; Lambert, D.; Roberts, C. \& Roberts, M.: Knowledge and the Future School: Curriculum and Social Justice. Londres: Bloomsbury, 141-160.

Landes, David S. (1969). The Unbound Prometheus: Technological Change and Industrial Development in Western Europe from 1750 to the Present. Cambridge: Press Syndicate of the University of Cambridge.

Lang, Fernando (2017). Sobre o formato da Terra. Física na Escola, 15(2), 4-14.

Laudan, Larry (1981). A Confutation of Convergent Realism. Philosophy of Science, 48, pp.19-48.

Laudan, Larry; Donovan, Arthur; Laudan, Rachel; Barker, Peter; Brown, Harold; Leplin, Jarret; Thagard, Paul \& Wykstra, Steve (1993). Mudança científica: modelos filosóficos e pesquisa histórica. Estudos Avançados, 7(19), 7-89.

Lederman, Norman (2007). Nature of science: past, present and future. In: Abell, S.K. \& Lederman, N.G. (eds).: Handbook of Research on Science Education. Mahwah, New Jersey: Lawrence Erlbaum Associates, pp.831-880.

(1992). Students' and teachers' conceptions of the nature of science: a review of the research. Journal of Research in Science Teaching, 26 (9), 771-783.

Lederman, N. G.; Abd-El-Khalick, F.; Bell, R. L. \& Schwartz, R. S. (2002). Views of Nature of Science Questionnaire: Toward Valid and Meaningful Assessment of Learners' Conceptions of Nature of Science. Journal or Research in Science Teaching, 39 (6), 497-521.

Lederman, N. G., Bartos, S. A., \& Lederman, J. S. (2014). The Development, Use, and Interpretation of Nature of Science Assessments. In: Matthews, M. R. (ed.): Intemational handbook of research in history, philosophy and science teaching. Dordrecht: Springer, 971-997.

Lederman, N. G., Wade, P., \& Bell, R. L. (1998). Assessing understanding of the Nature of Science: a historical perspective. In: McComas, W. F. (ed.): The Nature of Science in Science Education- Rationales and strategies. Dordrecht: Kluwer Academic Publisher, 331-350. 
Lederman, Norman \& Lederman, Judith (2014a). Research on Teaching and Learning of Nature of Science. In: Lederman, Norman \& Abell, Susan (eds.): Handbook of Research on Science Education. Volume II. New York: Routledge, 600-620. (2014b). Is Nature of Science Going, Going, Going, Gone? Journal of Science Teacher Education, 25, 235-238.

Leher, Roberto (2016): Commodification, a new problem in education. In: Leher, Roberto \& Accioly, Inny (orgs.). Commodifying Education Theoretical and Methodological Aspects of Financialization of Education Policies in Brazil. Rotterdam: Sense Publishers.

Leher, Roberto \& Vittoria, Paola (2016). The commodification of education in Brazil. In: Leher, Roberto \& Accioly, Inny (orgs.): Commodifying Education Theoretical and Methodological Aspects of Financialization of Education Policies in Brazil. Rotterdam: Sense Publishers, 106-122.

Levins, Richard \& Lewontin, Richard (2009). The dialectical biologist. Déli: AAKAR Books.

Lopes, Alice Casemiro \& Macedo, Elisabete (2011). Teorias de currículo. São Paulo: Cortez.

Lopes, Alice Casemiro \& Macedo, Elisabete (2015). Formação docente, um projeto impossível. Cadernos de Pesquisa, 45(157), 486-507.

Lopes, Alice Casemiro (2013). Teorias pós-críticas, política e currículo. Educação, Sociedade \& Culturas, 39, 7-23.

Lorentz, Hendryk (1983 [1895]). A experiência interferencial de Michelson. In: Lorentz, H.; Einstein, A. \& Minkowski, H.: O princípio da relatividade. Col. Textos fundamentais da física moderna, vol.I. Lisboa: Calouste Gulbenkian.

(1983 [1904]). Fenômenos eletromagnéticos num sistema com qualquer velocidade inferior à da luz. In: Lorentz, H.; Einstein, A. \& Minkowski, H.: $O$ princípio da relatividade. Col. Textos fundamentais da física moderna, vol.I. Lisboa: Calouste Gulbenkian.

Lustig, Nora (2015). Most unequal on Earth. Finance \& Development (Banco Mundial), Setembro, 14-16.

Macedo, Elizabeth (2017). As demandas conservadoras do movimento Escola Sem Partido e a Base Nacional Curricular Comum. Educação e Sociedade, 38(1), 507-524.

Magalhães, Gildo (2018). Ciência e Ideologia, uma excursão à história em torno da ideia de progresso. São Paulo: Intermeios (USP). 
(2016). A ciência é uma ideologia? Intelligere (Dossiê Georges Canguilhem, a história e os historiadores), 2(1), 100-111.

Martin, M. (1972). Philosophy of science and science education. Studies in Philosophy and Education, 7(3), 210-225.

Martins, Roberto de A. (2015). A origem histórica da relatividade restrita. São Paulo: Livraria da Física.

(2005). El empirismo en la relatividad especial de Einstein y la supuesta superación de la teoría de Lorentz y Poincaré. Epistemologia E Historia de la Ciencia, 11, 509-516.

Martins, André F. (2007). História e Filosofia da Ciência no Ensino: Há Muitas Pedras Nesse Caminho. Caderno Brasileiro de Ensino de Física, 24 (1), 112-131.

(2015). Natureza da ciência no ensino de ciências: uma proposta baseada em “temas” e “questões”. Caderno Brasileiro de Ensino de Física, 32 (3), pp.703-737.

Matthews, Michael (1993). Constructivism and Science Education: Some Epistemological Problems. Journal of Science Education and Technology, 2(1), 359370. Tradução livre de trechos.

(1994) Science teaching: the role of history and philosophy of science. Londres e Nova Yorque: Routledge.

(1995). História, filosofia e ensino de ciências: a tendência atual de reaproximação. Trad. Claudia Mesquita de Andrade. Caderno Catarinense de Ensino de Física, 12 (3), 164-214.

(1997). Introductory Comments on Philosophy and Constructivism in Science Education. Science \& Education, 6, 5-14. Tradução livre de trechos.

(1998a). Constructivism in Science Education: A Philosophical Examination. Dordrecht: Kluwer. Tradução livre de trechos.

(1998b). In defense of modest goals when teaching about the nature of science. Journal of Research in Science Teaching, 35(2), pp.61,174.

(2002). Constructivism and Science Education: A further appraisal. Journal of Science Education and Technology, 11(2), 121-134. Tradução livre de trechos.

(2004). Reappraising Positivism and Education: The Arguments of Philipp Frank and Herbert Feigl. Science \& Education, 13, 7-39.

(2012). Changing the Focus: From Nature of Science (NOS) to Features of Science (FOS). In: Khine, M.S.: Advances in Nature of Science Research. Dordrecht: Springer. 
(ed.) (2014). International Handbook of Research in History, Philosophy and Science Teaching. Vols. I e II. Dordrecht: Springer.

(ed.) (2017). History, Philosophy and Science Teaching. Dordrecht: Springer.

McComas, W. F. (1996). Ten myths of science: reexamining what we think we know. School Science \& Mathematics, 96, 1-10.

(1998). The principal elements of the nature of science: Dispelling the myths of science. In: McComas, W. F. (ed.): The Nature of Science in Science Education: Rationales and Strategies. Dordrecht: Kluwer Academic Publishers, 53-70.

(2014). Nature of Science in the Science Curriculum and in Teacher Education Programs in the United States. In: Matthews, M. R. (ed): International Handbook of Research in History, Philosophy and Science Teaching. Dordrecht: Springer, 1993-2023.

McComas, W. F., Clough, M. P., \& Almazroa, H. (1998). The Nature of Science in Science Education: an introduction. Science \& Education, 7, 511-532.

McComas, W. F., \& Olson, J. K. (1998). The Nature of Science in international science education standards documents. In McComas, W. F. (ed.): The nature of science in science education: rationales and strategies. Dordrecht: Kluwer Academic Publisher, 41-52.

McComas, W. \& Nouri, N. (2016). The Nature of Science and the "Next Generation Science Standards": Analysis and Critique. Journal of Science Teacher Education, 27(5), 555-576.

McGuire, James \& Tuchanska, Barbara (2013). Da ciência descontextualizada à ciência no contexto social e histórico. Revista Brasileira de História da Ciência, 6 (2), 151182.

Mészáros, István (2005). The Power of Ideology. Londres e Nova Yorque: Zed Books LTD.

(2006). A educação para além do capital. Trad. Isa Tavares. São Paulo: Boitempo.

Miller, Arthur I. (1981). Albert Einstein's Special Theory of Relativity: Emergence (1905) and Early Interpretation (1905-1911). Massachusets: Addison-Wesley Publications Company Inc., Advanced Book Program.

Mönckeberg, María Olivia (2007). El negocio de las universidades en Chile. Santiago: Debate. 
Moreira, A. F. B. \& Candau, V. M. (2007). Indagações obre currículo: currículo, conhecimento e cultura. Brasília: Ministério da Educação, Secretaria de Educação Básica.

Morgan, John (2015). Michael Young and politics of the school curriculum. British Journal of Educational Studies, 63(1), 5-22.

Morley, David \& Chen, Kuan-Hsing (2000). Introduction. In: Morley, David \& Chen, Kuan-Hsing (ed.): Stuart Hall, Critical dialogues in cultural studies. Londres e Nova Yorque: Routledge, 1-24.

Moura, B. A. (2014). O que é natureza da Ciência e qual sua relação com a História e Filosofia da Ciência? Revista Brasileira de História Da Ciência, 7(1), 32-46.

Muller, Johan (2012). Revisitando o progressivismo: ethos, política, pathos. In: Gargia, Regina \& Flavio, Antônio (orgs): Currículo na contemporaneidade, incertezas e desafios. São Paulo, Cortez, 317-344.

Nadai, Elza (1993). O ensino de história no Brasil: trajetória e perspectiva. Revista Brasileira de História, 13(25-26), 143,162.

Nanda, Meera (1999). Contra a destruição/desconstrução da ciência: histórias cautelares do terceiro mundo. In: Foster, John B. \& Wood, Ellen M.: Em Defesa da História. Marxismo e Pos-Modernismo. Trad. Ruy Jungmann. Rio de Janeiro: Jorge Zahar, 84106.

National Research Council. Next Generation Science Standards (NGSS) (2013). Disponível em: http://www.nextgenscience.org/next-generation-science-standards, acesso maio de 2016. (2013b).
Appendix
H. Disponível
em :

https://www.nextgenscience.org/sites/default/files/Appendix\%20H\%20\%20The\%20Nature\%20of\%20Science\%20in\%20the\%20Next\%20Generation\%20Scie nce\%20Standards\%204.15.13.pdf, acesso maio de 2016.

Netto, José P. (1985). Introdução. In: Marx, Karl: A miséria da filosofia. Trad. José P. Netto. São Paulo: Global, 9-32.

Niniiluoto, Ilka (1999). Critical Scientific Realism. Oxford: Oxford University Press.

Nola, Robert \& Irzik, Gürol (2005). Philosophy, Science, Education and Culture. Dordrecht: Springer. Tradução livre de trechos.

Nola, Robert (1997). Constructivism in Science and Science Education: A Philosophical Critique. Science and Education, 6, 55-83. 
Noronha, André. B. (2011). Reflexões sobre histórias das origens da teoria da relatividade especial. Monografia de conclusão de curso. Publicação interna. São Paulo.

(2014). Interpretando a Relatividade Especial: discutindo o debate Realismo e Antirrealismo Científicos no Ensino de Ciências. Dissertação de Mestrado em Ensino de Ciências. Universidade de São Paulo, Instituto de Física, Instituto de Química, Instituto de Biologia e Faculdade de Educação. São Paulo.

(2017). Considerations about the presence of the Nature of Science in official educational documents: a comparison between DCN (Brazil) and NGSS (USA). Proceddings of 2nd World Conference on Physics Education. Universidade de São Paulo, São Paulo, Brazil.

Noronha, André B. \& Gurgel, Ivã. (2012a). Ênfases históricas controversas sobre a teoria da relatividade especial em livros didáticos. Anais do XIV Encontro de Pesquisa em Ensino de Física. Maresias, São Paulo, 1-3.

(2012b). Reflexões sobre diferentes ênfases históricas do episódio das origens da teoria da relatividade especial e eimplicações para o ensino de ciências. Anais do $13^{\circ}$ Seminário Nacional de História da Ciência e Tencologia, São Paulo, 115.

(2015) On the relevance of a non consensus view of nature of science in science education: a political-curricular argument. Proceedings of 11th European Science Education Research Association Congress, Helsinque, Finlândia, 2015.

(2017). Nature of science as a powerful meta-knowledge. Proceedings of 12th European Science Education Research Association Congress, Dublin, Irlanda, 2017.

OECD (2013). PISA 2015: draft science framework. Disponível em https:/www.oecd.org/pisa/pisaproducts/Draft\%20PISA\%202015\%20Science \%20Framework\%20.pdf, acesso em Agosto de 2017, 1-54.

(2014). PISA Scientific Literacy: a short guide for Key Stage 4 teachers. Disponível em: http://learning.gov.wales/docs/learningwales/publications/141023pisascientific-literacy-a-short-guide-for-key-stage-4-teachers-en.pdf, acesso em agosto de 2017, 1-5.

Oliveira, Marcos Barbosa (2005). Ciência: força produtiva ou mercadora? Crítica Marxista, 21, pp. 76-96. 
(2013): On the commodification of science: the programmatic dimension. Science \& Education, (22), 2463-2483.

Oliveira, Fábio F.; Vianna, Deise M.; Gerbassi, Reuber S. (2007) Física moderna no Ensino Médio: o que dizem os professores. Revista Brasileira de Ensino de Física, 29(3), 447-454.

Osborne, Jonathan F. (1996). Beyond Constructivism. Science \& Education, 80(1), 53-82. Tradução livre de trechos.

Ostermann, Fernanda (1996). A epistemologia da Kuhn. Caderno Catarinense de Ensino de Física, 13(3), 184-196.

Ostry, Jonathan; Loungani, Prakash \& Davide Furceri (2016). Neoliberalism. Oversold? Finance \& Development (Banco Mundial), Junho, 38-41.

Paraskeva, João (2001). As dinâmicas dos conflitos ideológicos e culturais na fundamentação do currículo. Porto: ASA II Editores.

(2011). Conflicts in curriculum theory: challenging hegemonic epistemologies. New York: Palgrave MacMillan.

Peduzzi, L. (2005). Sobre a utilização didática da História da Ciência. In: Pietrocola, Maurício (org.): Ensino de física: conteúdo, metodologia e epistemologia em uma concepção integradora. 2a ed. Florianópolis: EDUFSC, 151-170.

Peres, João \& Neto, Moriti (2017). Gestado em sigilo, acordo McKinsey dita os rumos da USP. Revista ADUSP, 61, 31-39.

Pietrocola, Maurício (2002). A matemática como estruturante do conhecimento físico. Caderno Catarinense de Ensino de Física, 19(1), 89-109.

Poincaré, Henri (1898). La mesure du temps. Revue de Métaphysique et de Morale, 6(1), $1-13$.

(1905). Sur la dynamique de l'électron. Comptes rendus de l'Académie des Sciences, 140, pp. 489-493.

(1908). La dynamique de l'électron. Revue générale des sciences pures et apliquées, 19, 286-402.

(1984). A ciência e a hipótese. Trad. M. A. Kneipp. Brasília: EDUnB. (1995). O valor da ciência. Trad. Maria Helena Franco Martins. Rio de Janeiro: Contraponto.

Polanco, Xavier (1985). La ciencia como ficción. Historia y contexto. In: Saldaña, José: El perfil de la America. XI Congresso Interamericano de Filosofia. Atas do Simpósio Historia y Filosofia de la Ciencia em America. México: Cadernos de Quipu, 41-56. 
Pomar, Pedro E. (2015). Desmanche tem como alvos RDIDP e caráter público da universidade. Revista ADUSP, 58,79-86.

Pourois, Jean-Pierre \& Desmet, Huguette (1997). A educação pós-moderna. Lisboa: Instituto Piaget.

Praia, J., Gil-Pérez, D., \& Vilches, A. (2007). O papel da natureza da Ciência na educação para a cidadania. Ciência \& Educação, 13(2), 141-156.

Pumfrey, S. (1991). History of science in the National Science Curriculum: a critical review of resources and the aims. The British Journal for the History of Science, 24(1), 61-78.

Quale, Andreas (2007a). Radical Construtivism, and the sin of Relativism. Science \& Education, 16, 213-266. Tradução livre de trechos.

(2007b). The Epistemic Relativism of Radical Constructivism: Some Implications for Teaching the Natural Sciences. Constructivist Foundations, 2(2-3), 107-113. Tradução livre de trechos.

(2008). Is Ontology Necessary? Constructivist Foundations, 3(2), 81-82. Tradução livre de trechos.

(2010). Objections to Radical Constructivism. Constructivist Foundations, 6(1), 12-18. Tradução livre de trechos.

Rata, Elizabeth (2012). The politics of knowledge in education. British Educational Research Journal, 38(1), 103-124.

(2015). Multuculturalism and Education. In: Mansouri, Fethi (ed): Cultural Religious and Political Contestations: The Multicultural Challenge. New York, Dordrecht e London: Springer, 107-117.

Riad, Nagwa (2017): Education for life. Finance \& Development (Banco Mundial), Junho, 16-19.

Roberts, Carolyn (2014). Curriculum leadership and the knowledge-led school. In: Young, M.; Lambert, D.; Roberts, C. \& Roberts, M.: Knowledge and the Future School: Curriculum and Social Justice. Londres: Bloomsbury, 124-140.

Robilotta, Manoel R. (1988). O cinza, o branco e o preto - da relevância da história da ciência no ensino de física. Caderno Catarinense de Ensino de Física, 6(número especial), 7-22.

Romero-Maltrana, Diego; Benitez, Federico; Vera, Francisco \& Rivera, Rodrigo (2017). The 'Nature of Science' and the perils of epistemic relativism. Research in Science Education, publicado online (novembro de 2017), 1-23. 
Roose, Joshua M. \& Possamai, Adam (2015). Between Rhetoric and Reality: Shari'a and the Shift Towards Neoliberal Multiculturalism in Australia. In: Mansouri, Fethi (ed): Cultural Religious and Political Contestations: The Multicultural Challenge. New York, Dordrecht e London: Springer, 91-107.

Roth, Wolff-Michael (1998). Science and Technology Studies and Science Education: A Natural Match? Research in Science Education, 28(1), 1-7.

Rowbotton, Nick (2013). A-Level Subject Choice, Systematic Bias and University Performance in the UK: The Case of Accounting. Accounting Education, 22(3), 248267.

Rudolph, John (2015). Myth 23. That the Soviet Launch of Sputnik Caused the Revamping of American Science Education. In: Numbers, Ronald \& Kampourakis, Kostas (eds.) (2015): Newton's Apple and Other Myths About Science. Cambridge: Harvard University Press, 186-194.

Saviani, Dermeval (2012). Marxismo, educação e pedagogia. In: Saviani, Dermeval \& Duarte, Newton (orgs.): Pedagogia histórico-crítica e luta de classes na educação escolar. Campinas: Autores Associados, 59-86.

Saviani, Dermeval \& Duarte, Newton (2012). A formação humana na perspectiva histórico-crítica. In: Saviani, Dermeval \& Duarte, Newton (orgs.): Pedagogia histórico-crítica e luta de classes na educação escolar. Campinas: Autores Associados, 13-36.

Schwartz, R. S., Lederman, N. G., \& Abd-EI-Khalick, F. (2012). A series of misrepresentations: A response to Allchin's whole approach to assessing nature of science understandings. Science Education, 96(4), 685-692.

Schwartzman, Simon (2015): Introduction: Regional Overview. In: Schwartzman, S. (ed). Education In South America. London: Bloomsbury, 1-20. (2016). Em busca de novos caminhos para os ensinos médio e técnico. In: Schwartzman, Simon (org.). Educação média profissional no Brasil: situação e caminhos. São Paulo: Fundação Santilliana, 179-199.

Shapin, Steve (1996). The Scientific Revolution. Chicago e Londres: University of Chicago Press.

(2012). Como ser anticientífico. In: Shapin, Steve: Nunca pura: estudos históricos de ciência como se fora produzida por pessoas com corpos, situadas no tempo, no espaço, na cultura e na sociedade que se empenham por credibilidade $e$ autoridade. Trad. Erick Ramalho. Belo Horizonte: Fino Traço Editora \& EDUEPB. 
Selles, Sandra E. (2016). A polêmica instituída entre ensino de evolução e criacionismo: dimensões do público e do privado no avanço do neoconservadorismo. Ciência \& Educação, 22(4), 831-835.

Sen, N. R. (1927). On Fresnel's convection coefficient in general relativity. Proceedings of the Royal Society A,116(773), 73-80.

Sheehan, Helena (1993). Marxism and the philosophy of science: a critical history: the first hundred years. Nova Jersey: Humanities Press International Inc.

Silva, Tomaz. T. (1993). Desconstruindo o construtivismo pedagógico. Educação \& Realidade, 18(2), 3-10.

(2010). Documentos de identidade: Uma introdução às teorias de currículo. $3^{\text {a }}$ ed. Belo Horizonte: Autêntica.

Silva, Mônica Ribeiro (2008). Currículo e competências: a formação administrada. São Paulor: Cortez.

Sim, Stuart (2011a). Preface to the third edition: the modern, the postmodern and the post-postmodern. In: Sam, S. (ed.): The Routledge Companion to Postmodernism. Londres e Nova Yorque: Routledge Taylor \& Francis Group.

(2011b). Post-modernism and philosophy. In: Sim, S. (ed.): The Routledge Companion to Postmodernism. Londres e Nova Yorque: Routledge Taylor \& Francis Group, 3-14.

Skordoulis, Constantine (2009). Science and worldviews in the marxist tradition. In: Matthews, Michael (ed).: Science, worldviews and education. Dordrecht: Springer, 257-270.

Smith, M. U., Lederman, N. G., Bell, R. L., McComas, W. F., \& Clough, M. P. (1997). How great is the disagreement about the nature of science: A response to Alters. Joumal of Research in Science Teaching, 34(10), 1101-1103.

Sokal, Alan \& Bricmont, Jean (1998). Intellectual Impostures. London: Profile Books.

Solomon, Joan (1994). The Rise and Fall of Constructivism. Studies in Science Education, 23, 1-19.

Song, Sarah (2017). Multiculturalism. Stanford Encyclopedia of Philosophy. Disponível em: https://plato.stanford.edu/entries/multiculturalism/, acesso julho de 2017.

Spolidoro, Marcello M. F. \& Reis, José C. (2017). A abordagem histórico-filosófica da ciência em 19 anos de Exame Nacional do Ensino Médio: aleatoriedade ou tendência? Enseñanza de las Ciências, número especial (X Congreso International sobre Investigación em Didáctica de las Ciencias. Sevilla), 3773-3778. 
Spring, Joel (2010). Political agendas for education: from Change We Can to Putting America First. $4^{\text {th }}$ ed. Nova Yorque e Londres:Routledge.

Stachel, John (2005). O ano miraculoso de Einstein. Cinco artigos que mudaram a face da física. $2^{\text {a }}$ ed. Trad. Alexandre Carlos Tort. Rio de Janeiro: EDUFRJ.

Staver, John R. (2012). Constructivism and Realism: Dueling Paradigms. In: Fraser, B.J et al. (eds): Second International Handbook of Science Education. Springer International Handbooks of Education. Dordrecht: Springer, 1017-1027.

Tate, W. (2001). Science education as a civil right: Urban schools and opportunity-tolearn considerations. Journal of Research in Science Teaching, 38(9), 1015-1028.

Tilly, Charles (2006). O acesso desigual ao conhecimento científico. Trad. Alexandre Massella. Tempo Social, 18(2), 47-63.

Tobin, Kenneth (1993). Preface. In: Tobin, Kenneth (ed.): The Practice of Constructivism in Science Education. Hillsdale: Lawrence Erlbaum Associates Publishers, pp.ix-xvi. (2007). Key contributors: Ernst von Glasersfeld's radical constructivism. Cultural Studies of Science Education, 2, 529-538.

Toledo, Maria A. L. T. (2004). A história ensinada sob o império da memória: questões de História da disciplina. História, 23(1-2), 13-32.

Usher, Abbott P. (1988). A History of mechanical inventions. Ed. rev. Cambridge: Dover.

Usher, Robin \& Edwards, Richard (1994). Postmodernism and education: different voices, different worlds. Londres e Nova Yorque: Routledge Ed.

Ventura, Zuenir (1988). 1968, o ano que não terminou. Rio de Janeiro: Nova Fronteira.

Venville, Grady; Rennie, Léonie \& Wallace; John (2012). Curriculum integration: challenging the assumption of school science as powerful knowledge. In: Fraser, Barry; Tobin, Kenneth \& McRobbie, Campbell (eds.).: Second International Handbook of Science Education. Dordrecht: Springer, 737-750

Vieira, Márcio Franco Xavier (2009). Fundamentos Filosóficos do Construtivismo: Reflexões críticas sobre os princípios que sustentam a organização do ensino em ciclos. São Paulo: Editora Isis.

Vilches, Amparo \& Gil-Pérez, Daniel (2012). The supremacy of the constructivist approach in the field of physics education: myths and real challenges. Tréma, 38, 1-18. von Glasersfeld, Ernst (1995). Construtivismo Radical: uma forma de conhecer $e$ aprender (Radical Constructivism: A Way of Knowing and Learning). Trad. Fernanda Oliveira. Rev. João Paz. Lisboa: Instituto Piaget. 
Waddington, D.J. (1987). The needs of industry. In: Waddington, D.J. (ed.): Education, Industry and Techonology. Oxford: ICSU Press, Pergamon Press, 221-223.

Weinstein, Matthew (2017). NGSS, disposability, and the ambivalence of science in/under neoliberalism. Cultural Studies of Science Education, 12, 821-834.

Wheelahan, Leesa (2010). Why Knowledge Matters in Curriculum, A social realist argument. Londres e Nova Yorque: Routledge.

Whitaker, M.A.B. (1979). History and quase-history in physics education. Partes I \& II. Physics Education, 14, 108-112, 239-242.

Worral, John (1989). Structural Realism: The Best of Both Worlds? Dialectica, 43(1-2), 99-124.

Yacoubian, H. (2013). Scientific Literacy for Social Reproduction. Atas do European Conference on Curriculum Studies. Universidade de Minho, Braga, Portugal, 910-914. (2015). A Framework for Guiding Future Citizens to Think Critically About Nature of Science and Socioscientific Issues. Canadian Journal of Science, Mathematics and Technology Education, 15(3), 248-260.

Young, Michael (1958). The rise of meritocracy: an essay on education and equality. Bristol: Penguin Books.

Young, Michael F. (ed.) (1971). Knowledge and Control: New Directions for the Sociology of Education. Londres: Collier-MacMillan Publishers.

(1989). Currículo e democracia: lições de uma crítica à 'nova sociologia da educação’. Educação \& Realidade, 14(1), 29-40.

(2011). O futuro da educação em uma sociedade do conhecimento: o argumento radical em defesa de um currículo centrado em disciplinas. Trad. Laura Beatriz Áreas Coimbra. Rev. Antônio Flávio Barbosa Moreira. Revista Brasileira de Educação, 48 (16), 609-623.

(2011b). O futuro da educação em uma sociedade do conhecimento: a defesa radical de um currículo disciplinar. Trad. Helena Beatriz Mascarenhas de Souza. Cadernos de Educação, 38, 395-416.

(2014a). What is a curriculum and what it can do? British Journal of Educational Studies, 63(1), 5-22.

(2014b). Knowledge, curriculum and the future school. In: Young, M.; Lambert, D.; Roberts, C. \& Roberts, M.: Knowledge and the Future School: Curriculum and Social Justice. Londres: Bloomsbury, 25-48. 
(2014c). Powerful knowledge as a curriculum principle. In: Young, M.; Lambert, D.; Roberts, C. \& Roberts, M.: Knowledge and the Future School: Curriculum and Social Justice. Londres: Bloomsbury, 68-86. (2015). Curriculum theory and the question of knowledge: a response to the six papers. Journal of Curriculum Studies, 47(6), 820-837. (2016a). Conhecimento e Currículo, do socioconstrutivismo ao realismo social na sociologia da educação (Bringing knowledge back in). Trad. Jorge Ávila de Lima. Porto: Porto Editora.

(2016b). Why knowledge matters for the schools of the $21^{\text {st }}$ century? Cadernos de Pesquisa, 46 (159), 1-17.

(2018). Appreciation and a response. In: Guile, D.; Lambert, D. \& Reiss, Michael J.: Sociology, Curriculum Studies and Professional Knowledge: New perspectives on the work of Michael Young. London e Nova Yorque: Routledge (Ebook), 383-407.

Zahar, Elie (1973). Why Did Einstein's Programme Supercede Lorentz's? British Journal for the Philosophy of Science, 24(2-3), 95-123 (2) e 223-262 (3).

Zanetic, João (1989). Física também é cultura. Tese de Doutorado. Faculdade de Educação da Universidade de São Paulo, São Paulo.

Zaleśny, Jarosław (2009). Applications of the Dirac Form of the Maxwell Equations in Moving Dielectric Media. International Journal of Theoretical Physics, 48, 18011912.

Zavale, Nelson (2013). Using Michael Young's Analysis on Curriculum Studies to Examine the Effects of Neoliberalism on Curricula in Mozambique. Policy Futures in Education, 11(5), 621-636.

Zizek, Slavok (ed.) (1994). Mapping ideology. Londres e Nova York: VERSO. 